\title{
Symptom validity in clinical assessments
}

Citation for published version (APA):

Dandachi - Fitzgerald, B. (2017). Symptom validity in clinical assessments. [Doctoral Thesis, Maastricht University]. Maastricht University. https://doi.org/10.26481/dis.20170602bdf

Document status and date:

Published: 01/01/2017

DOI:

10.26481/dis.20170602bdf

Document Version:

Publisher's PDF, also known as Version of record

\section{Please check the document version of this publication:}

- A submitted manuscript is the version of the article upon submission and before peer-review. There can be important differences between the submitted version and the official published version of record.

People interested in the research are advised to contact the author for the final version of the publication, or visit the DOI to the publisher's website.

- The final author version and the galley proof are versions of the publication after peer review.

- The final published version features the final layout of the paper including the volume, issue and page numbers.

Link to publication

\footnotetext{
General rights rights.

- You may freely distribute the URL identifying the publication in the public portal. please follow below link for the End User Agreement:

www.umlib.nl/taverne-license

Take down policy

If you believe that this document breaches copyright please contact us at:

repository@maastrichtuniversity.nl

providing details and we will investigate your claim.
}

Copyright and moral rights for the publications made accessible in the public portal are retained by the authors and/or other copyright owners and it is a condition of accessing publications that users recognise and abide by the legal requirements associated with these

- Users may download and print one copy of any publication from the public portal for the purpose of private study or research.

- You may not further distribute the material or use it for any profit-making activity or commercial gain

If the publication is distributed under the terms of Article $25 \mathrm{fa}$ of the Dutch Copyright Act, indicated by the "Taverne" license above, 


\section{Symptom validity in clinical assessments}



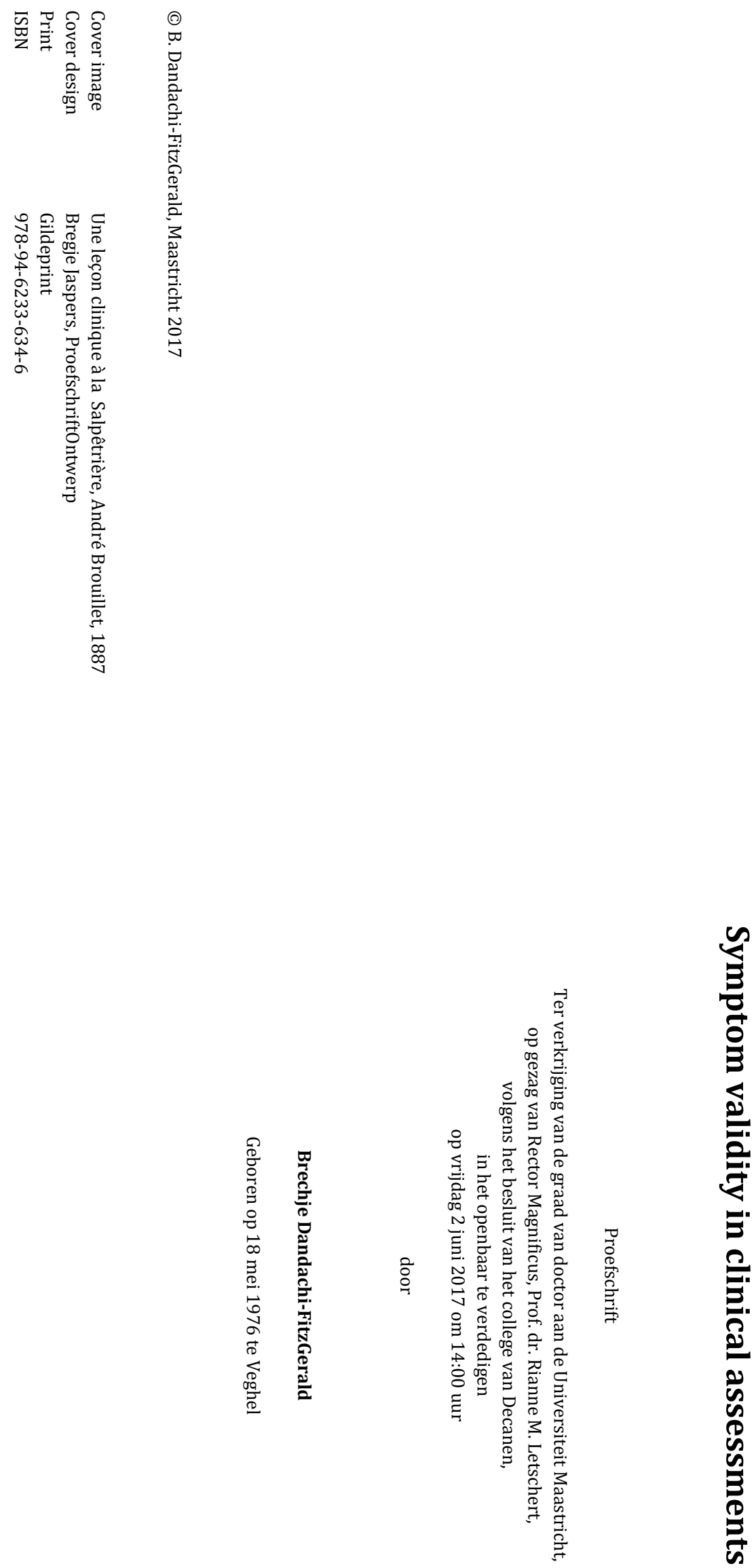


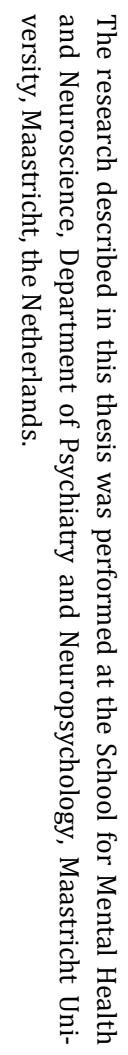
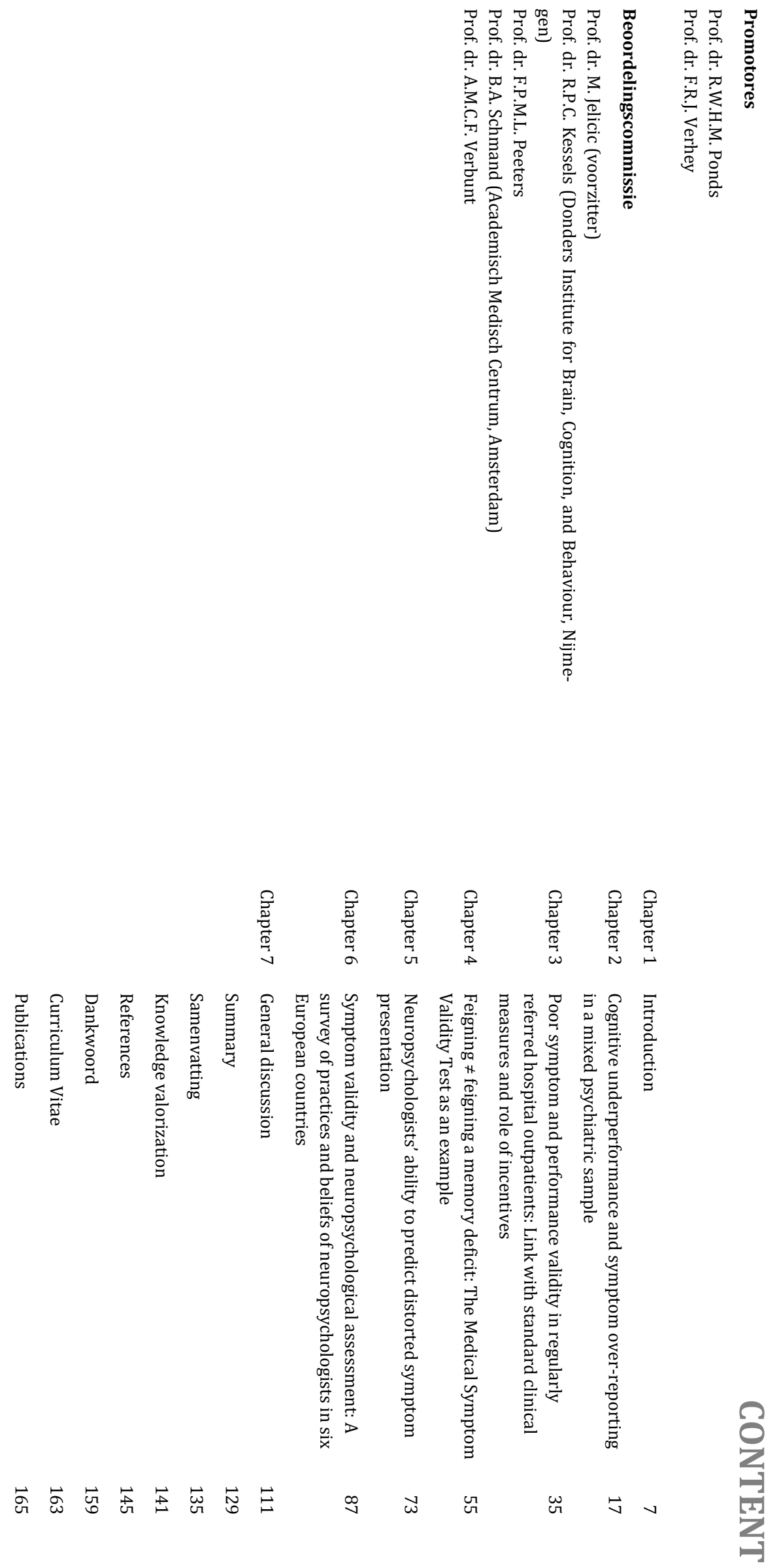

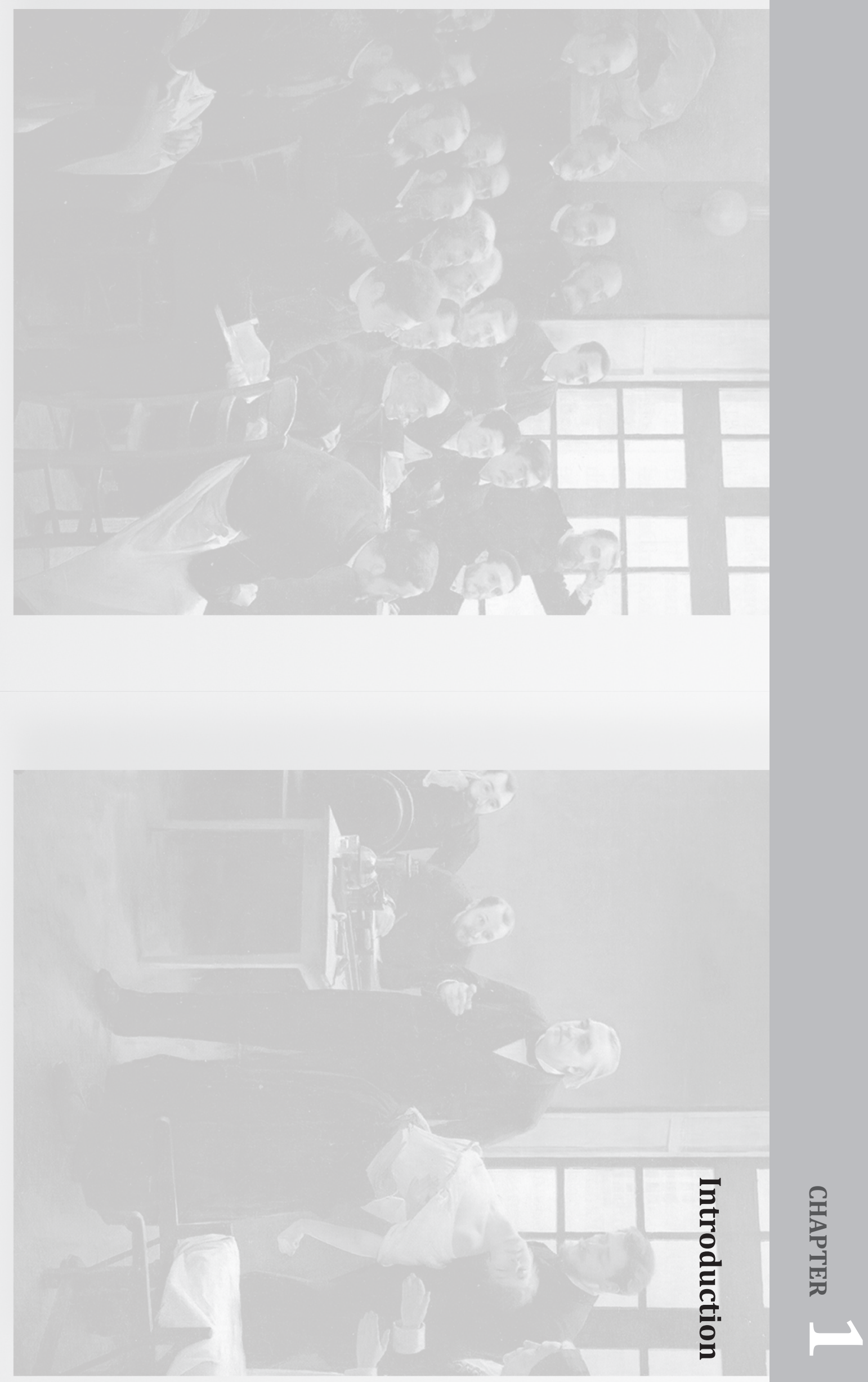


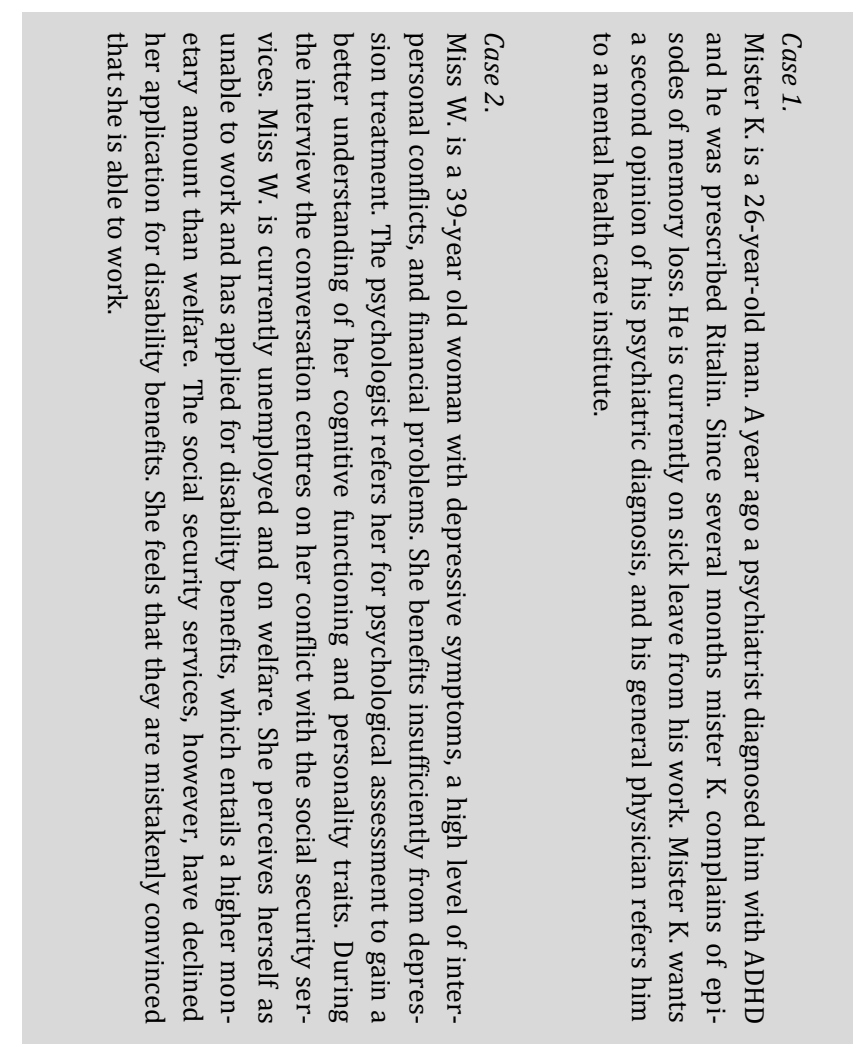

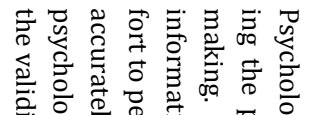

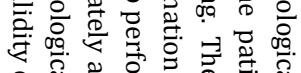

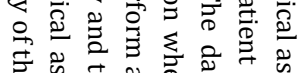

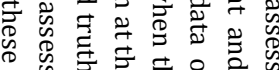

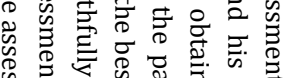

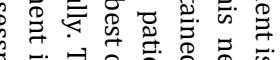

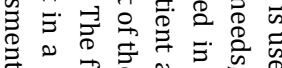

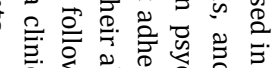

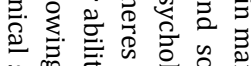

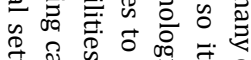
节.

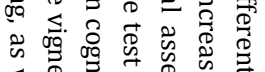

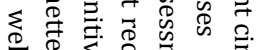
\% i 0 i ज्ञे के के

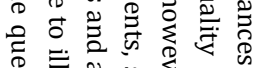

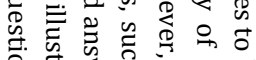

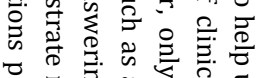

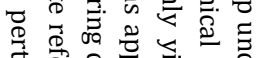

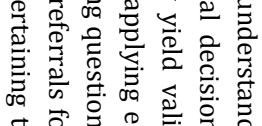

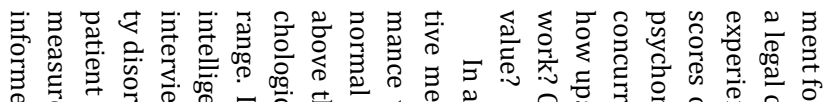

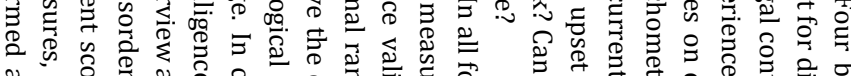

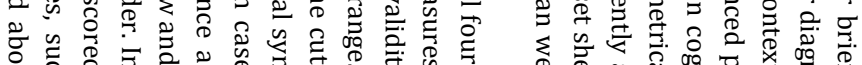

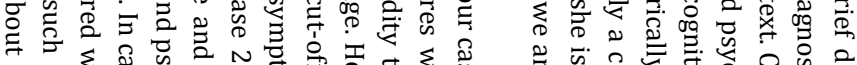

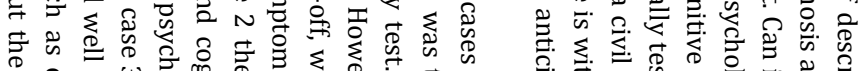

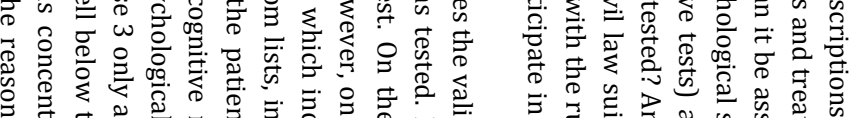

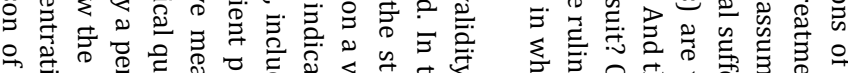

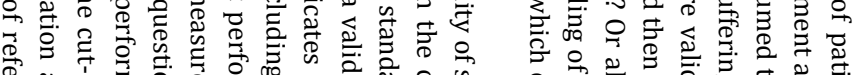

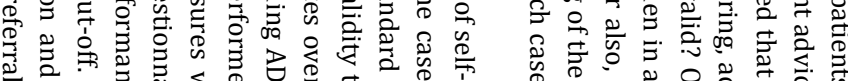

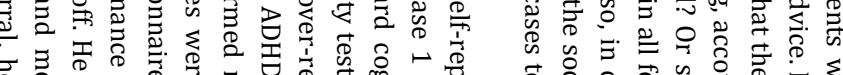

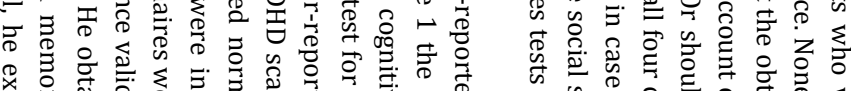

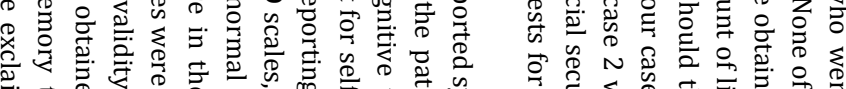

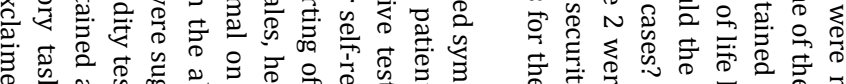

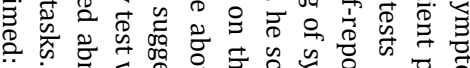

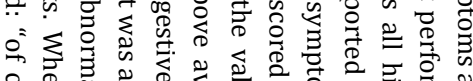

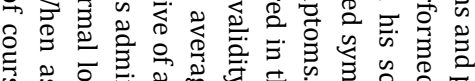

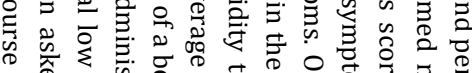

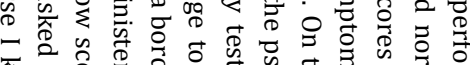

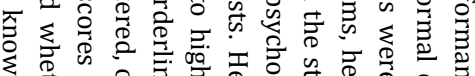

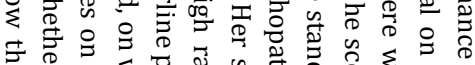

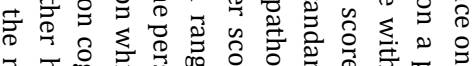

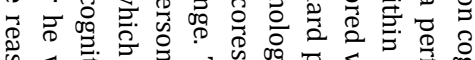

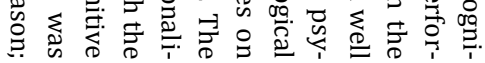

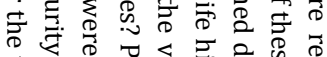

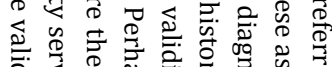
言

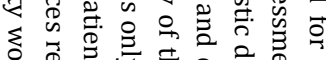

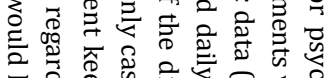

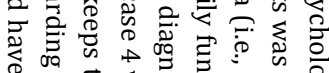

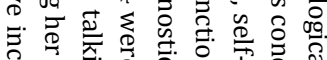

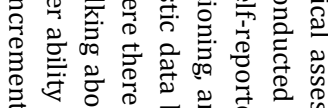

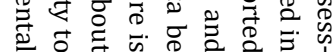

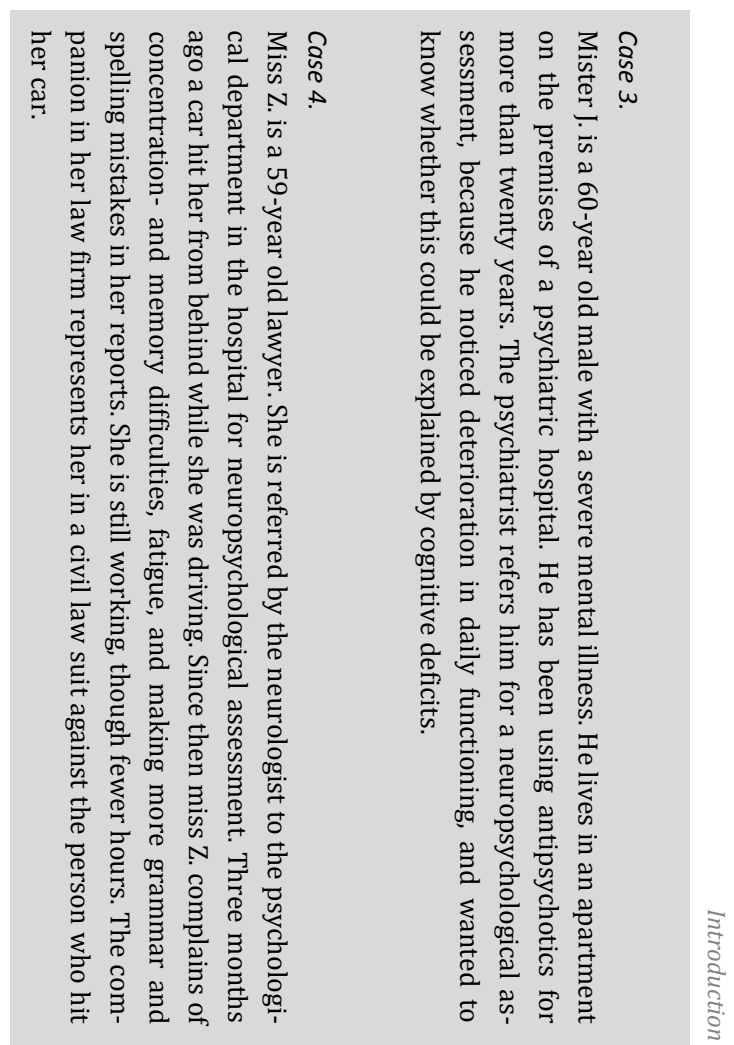




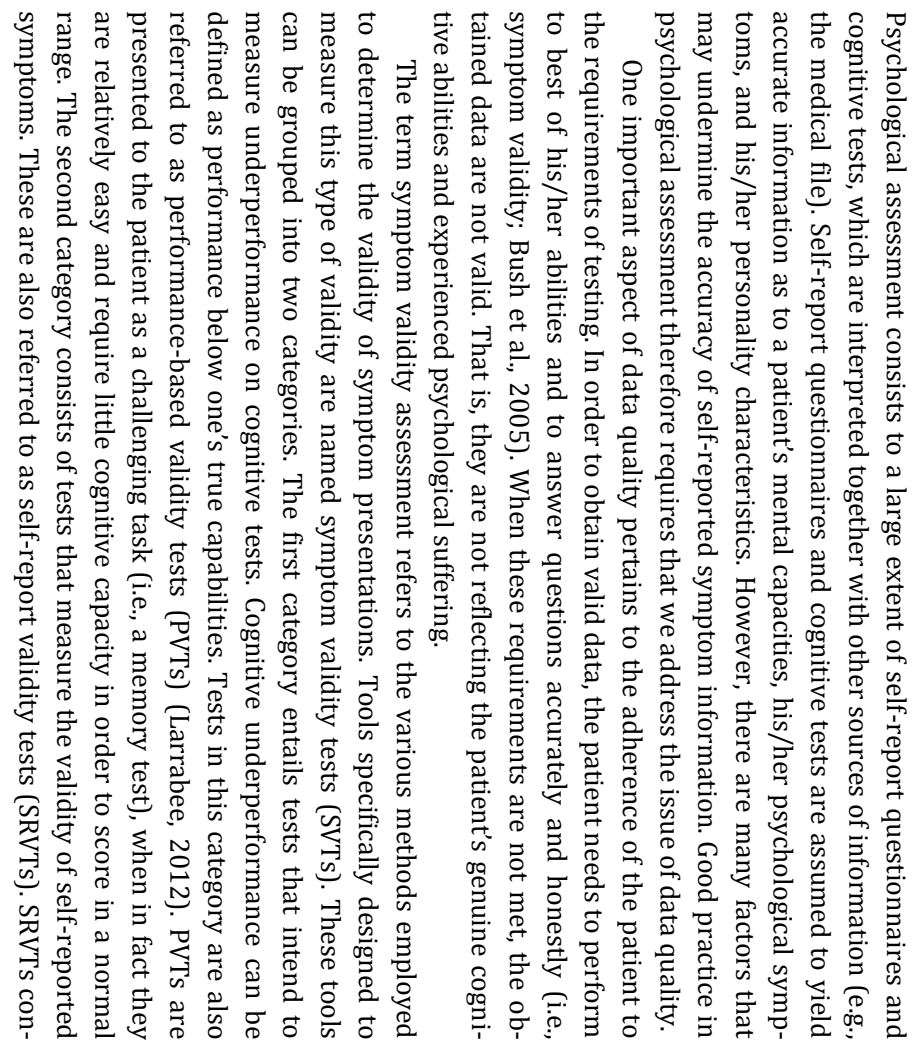



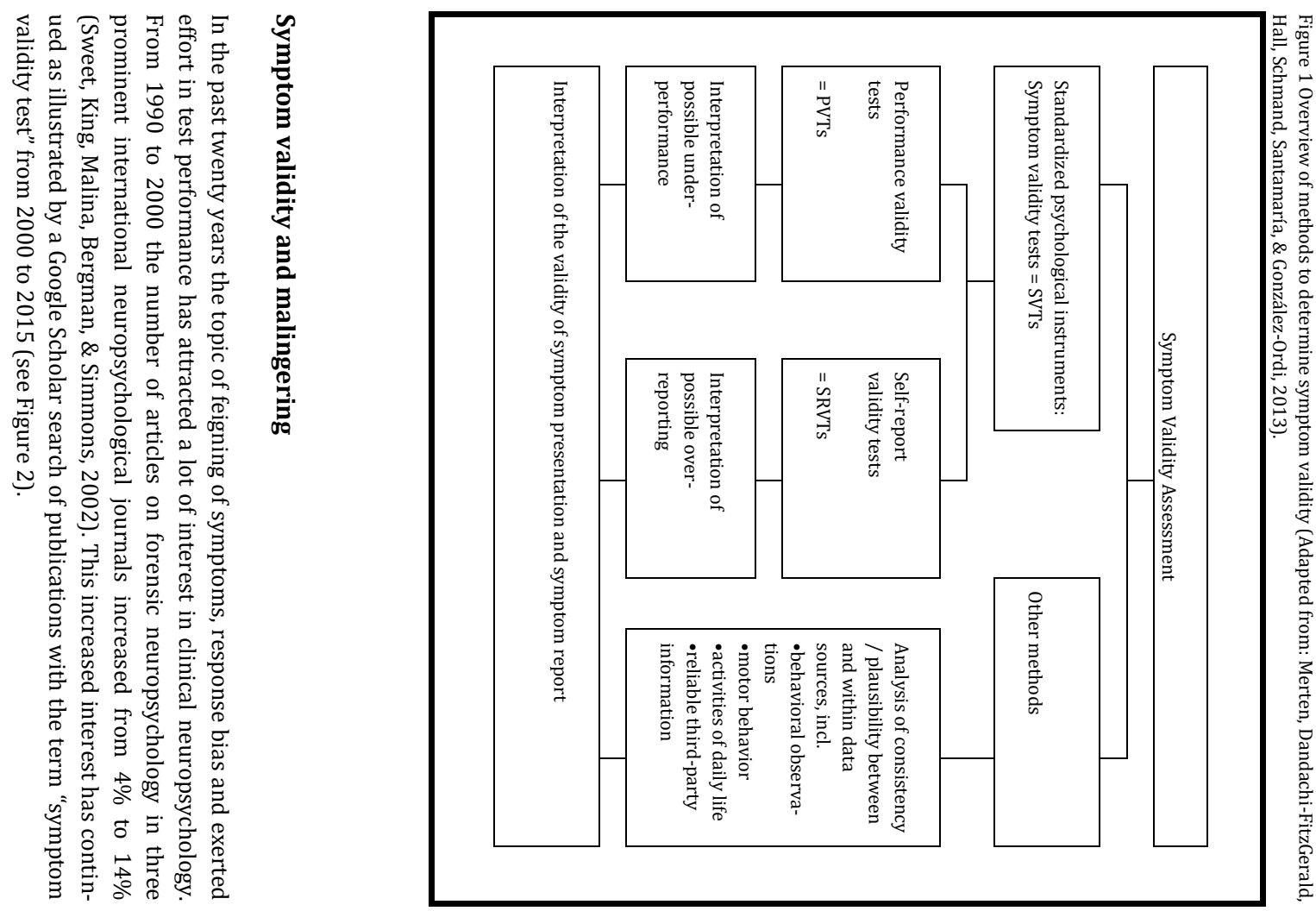

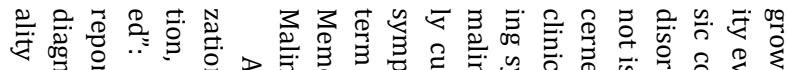

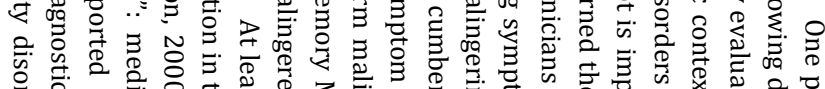

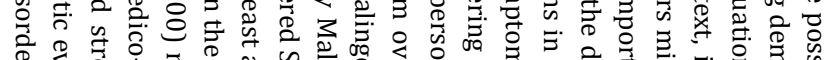

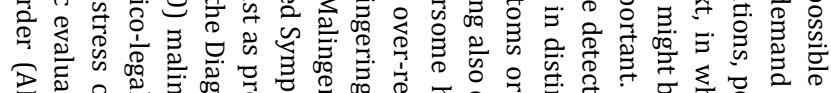

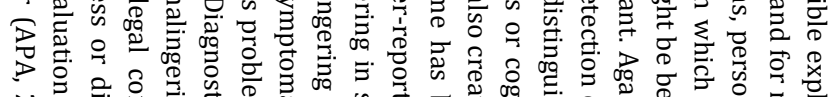

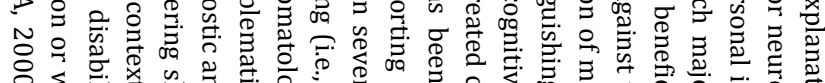

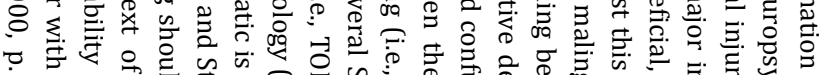

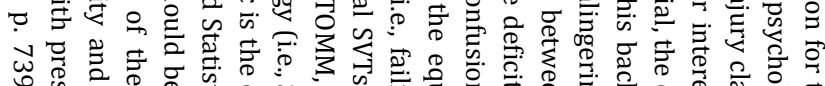

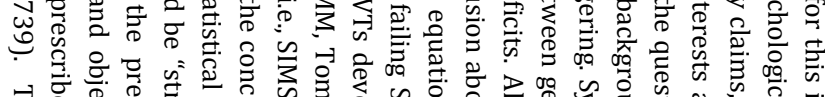

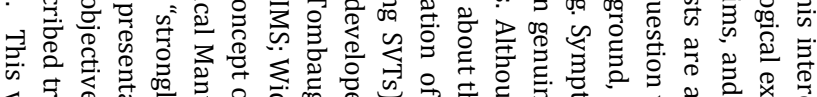

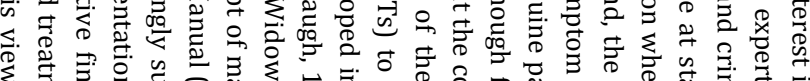

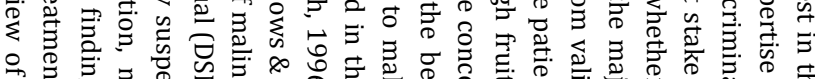

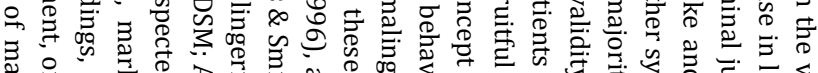

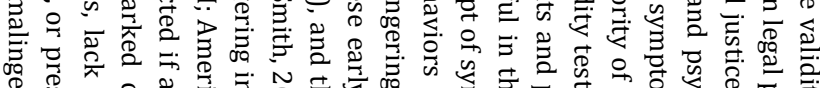

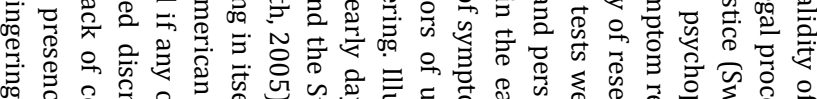

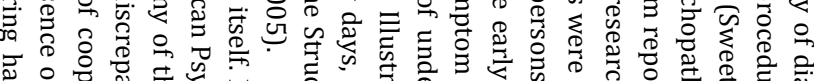

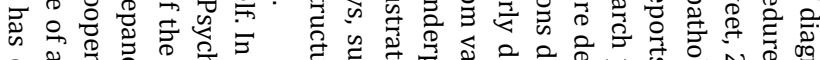

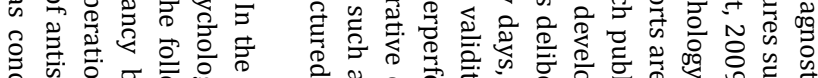

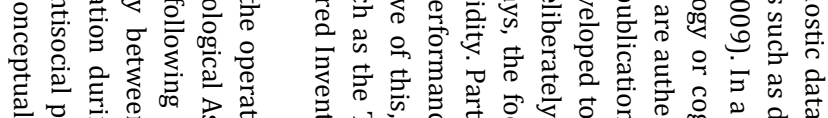

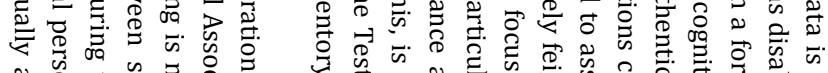

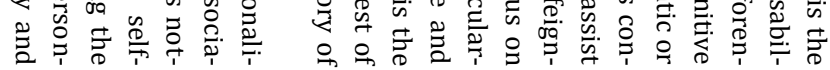

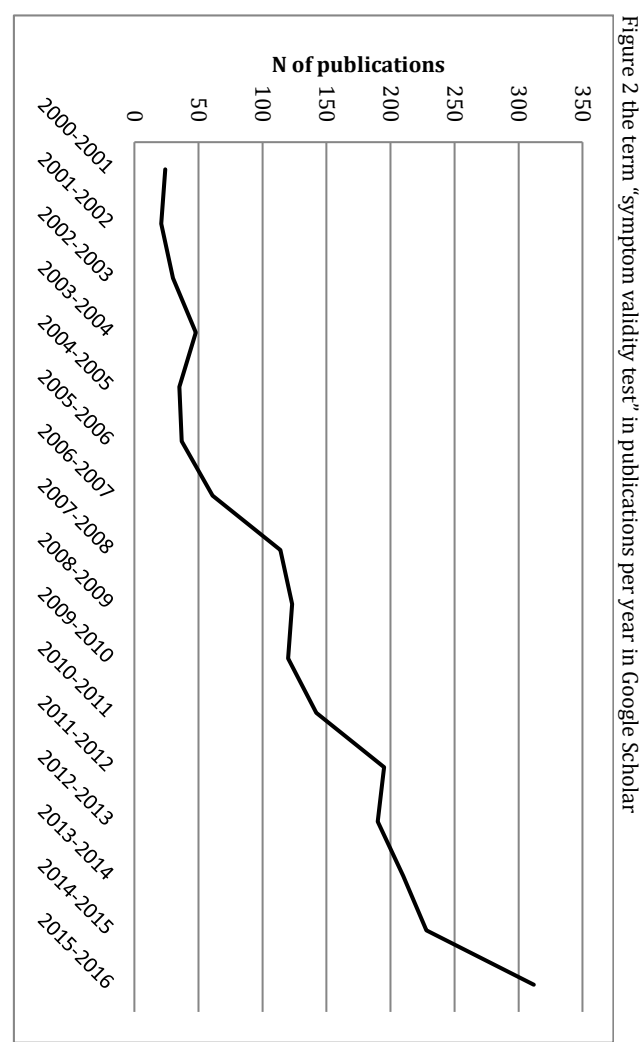




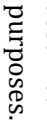

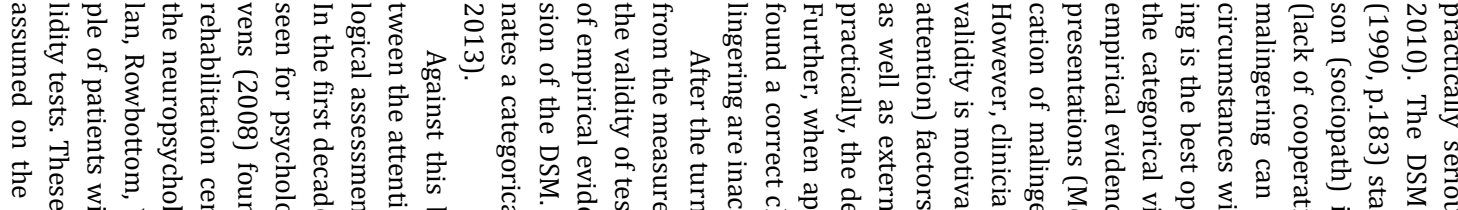

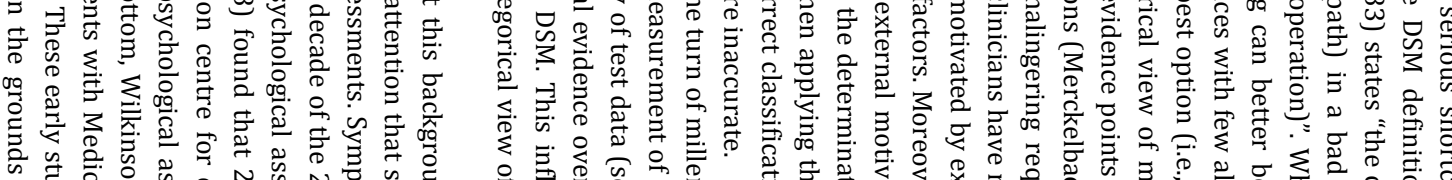

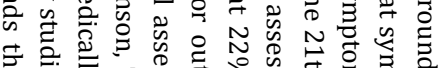

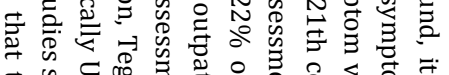

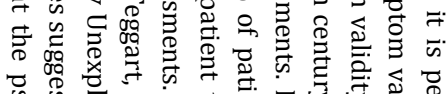

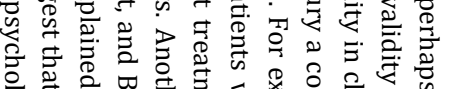

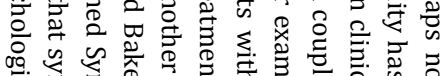

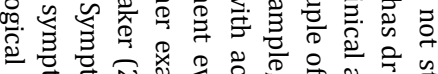

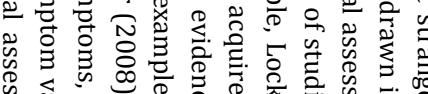

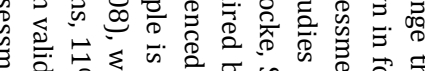

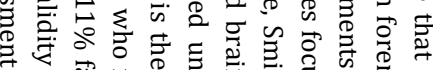

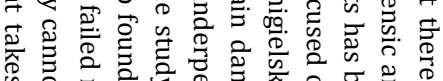

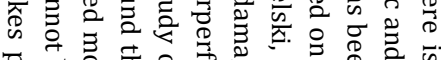

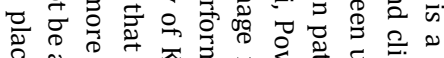

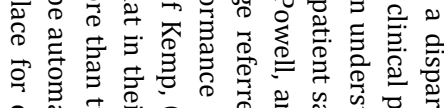

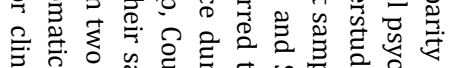

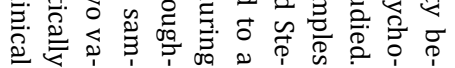

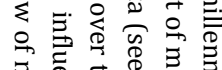

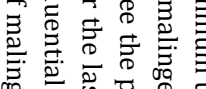

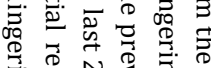

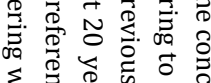

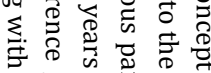

它

仓ิ

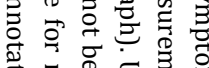

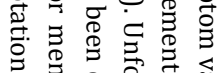

웜

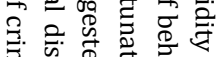

於.

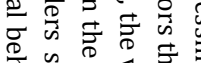

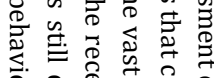

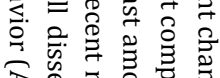

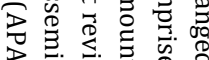

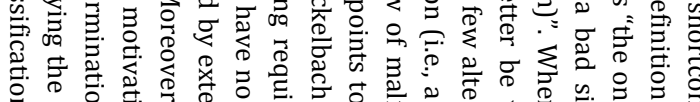
के

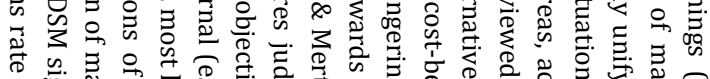

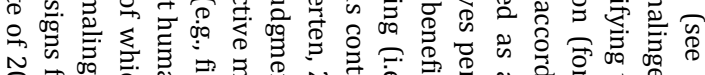

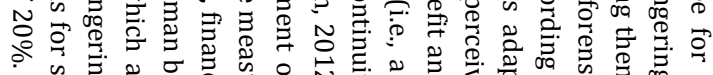

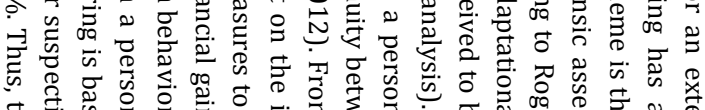

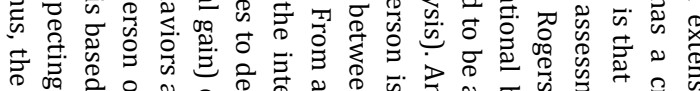

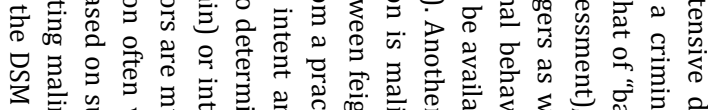

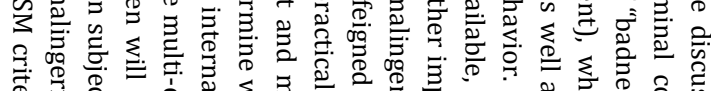

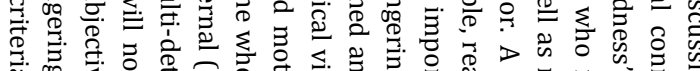

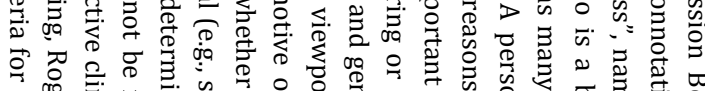

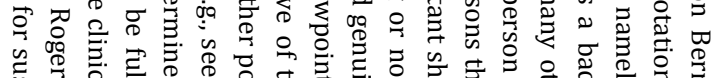

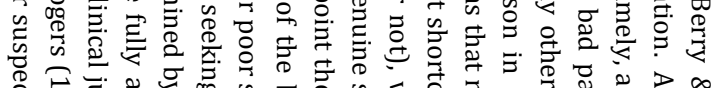

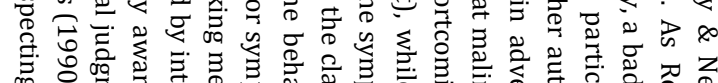

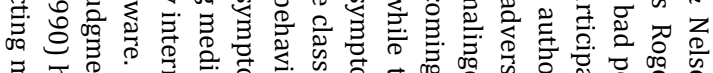

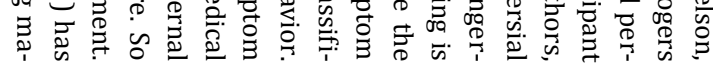

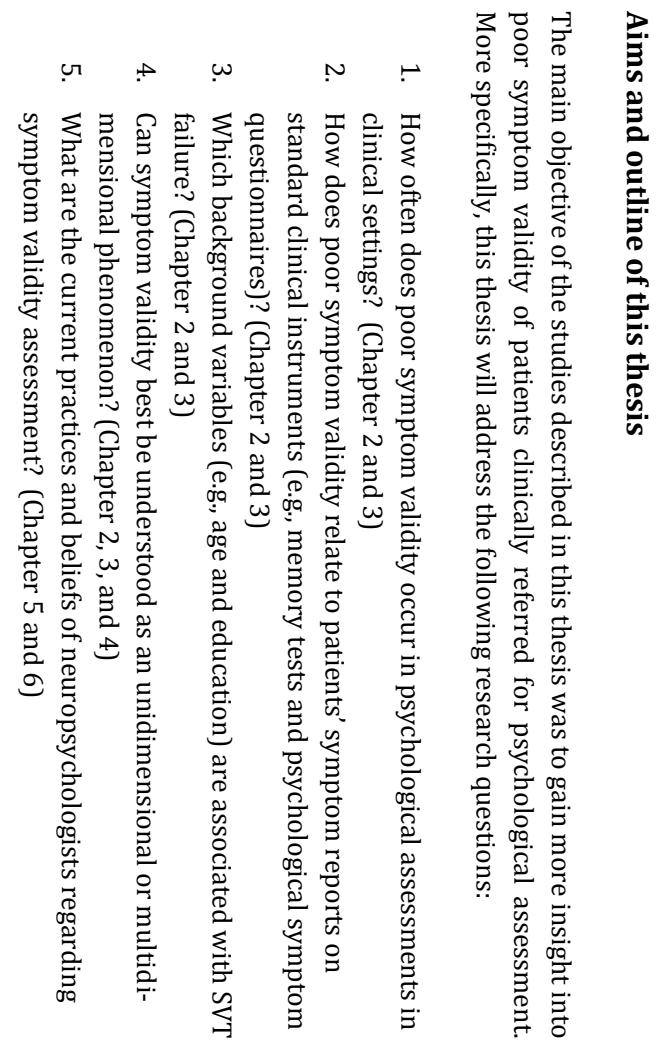



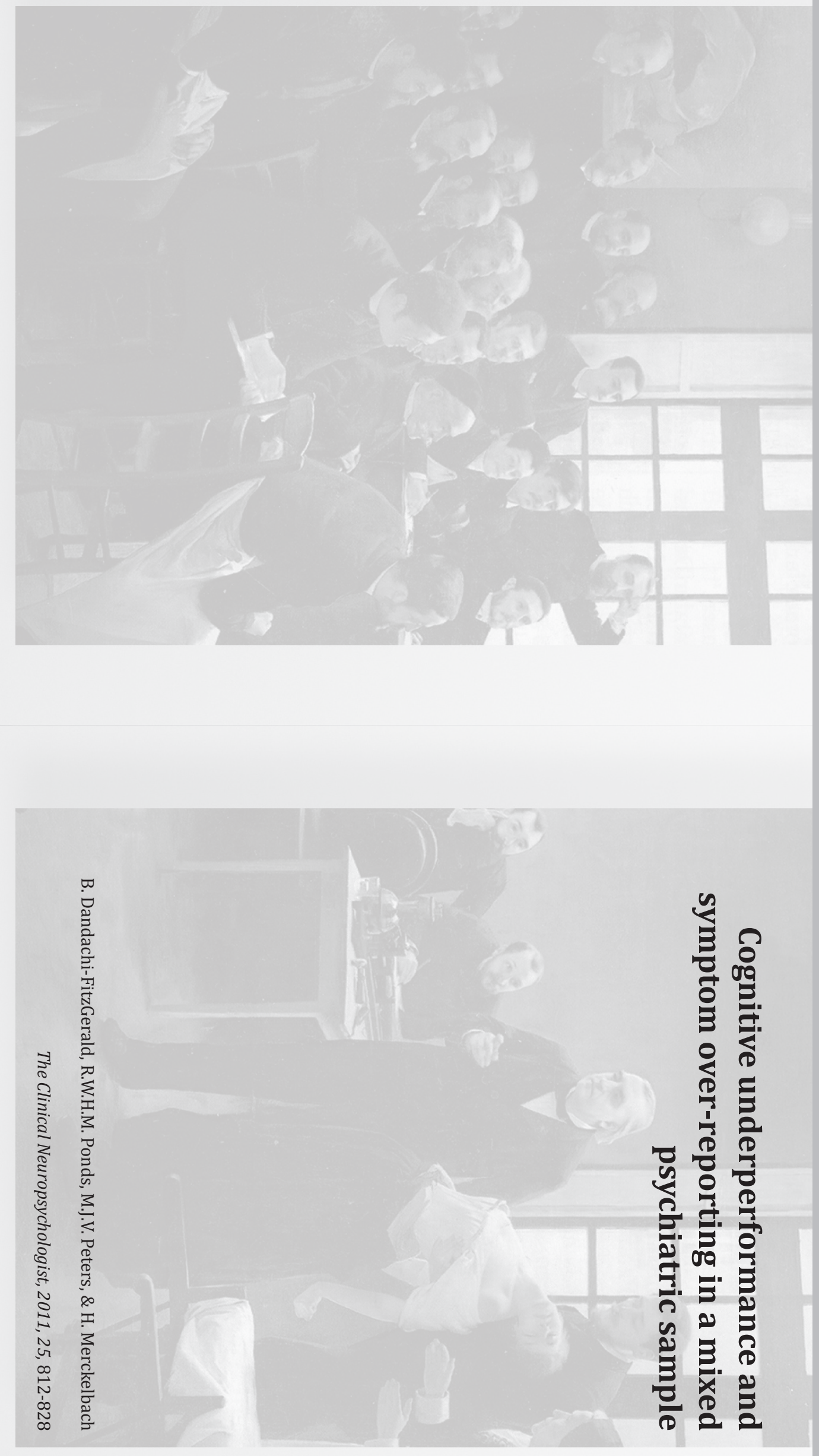

밈 


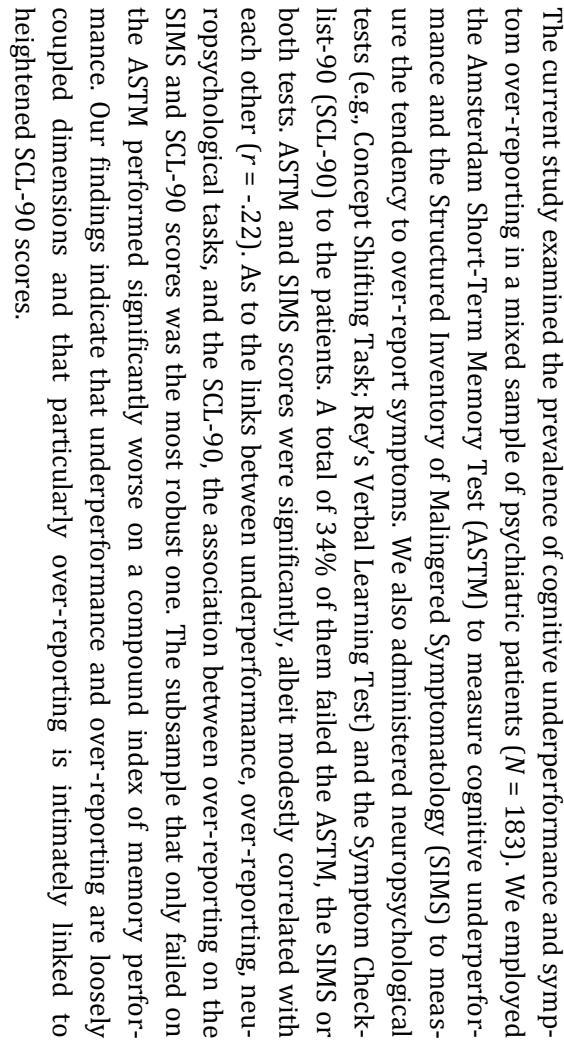

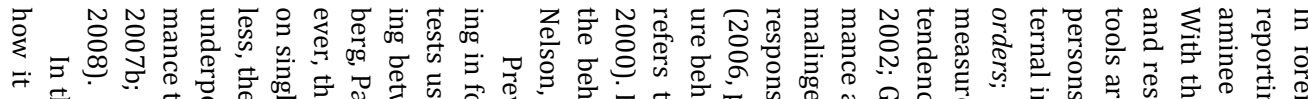

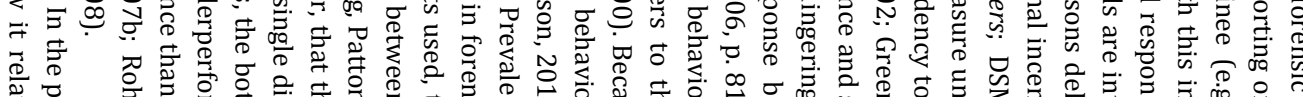

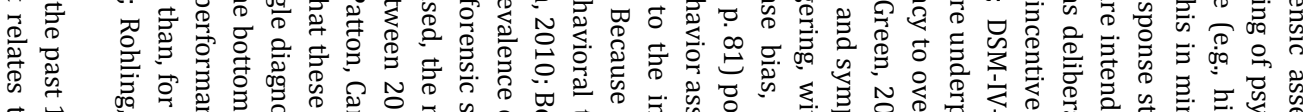
ธ

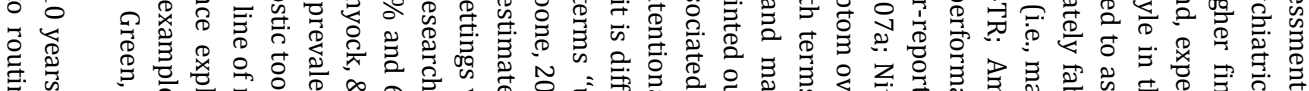

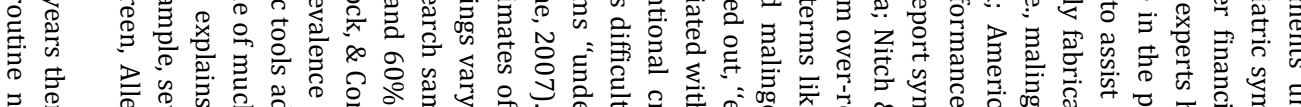

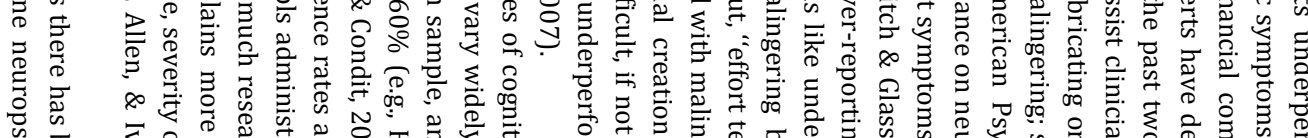

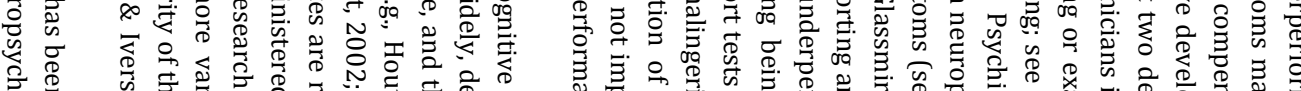

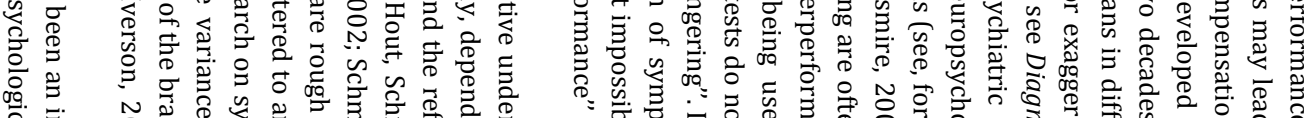

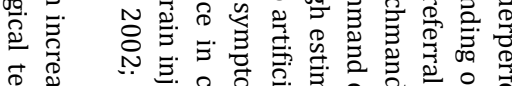

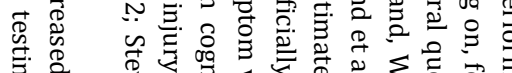

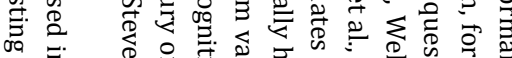

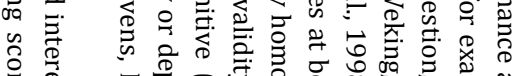

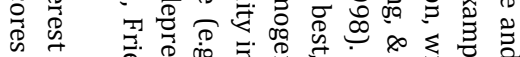
F. $\overline{0}$ Dे

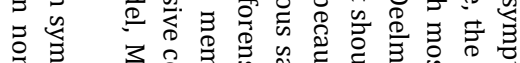

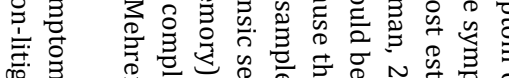

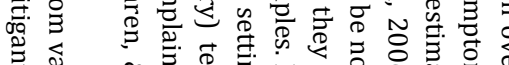

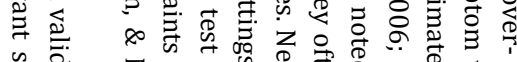

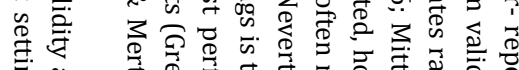

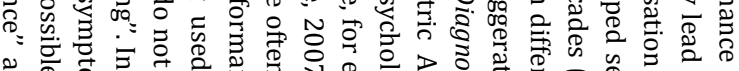

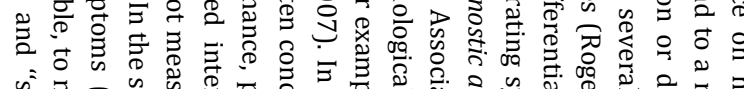

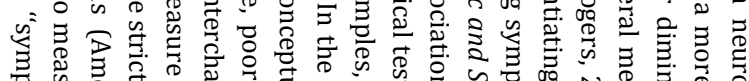

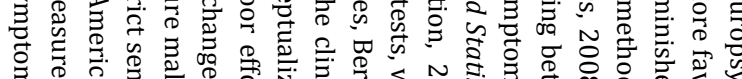

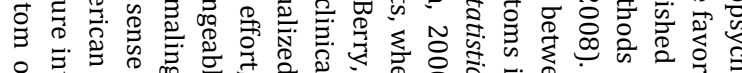

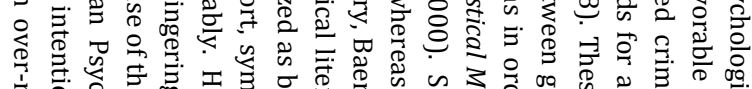

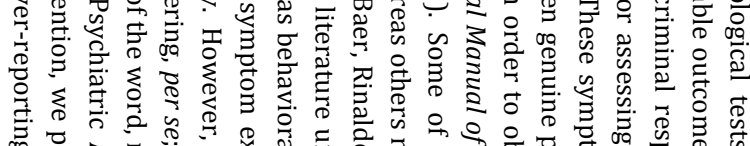

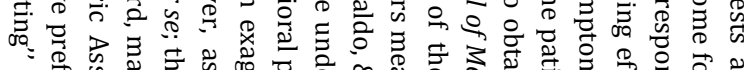

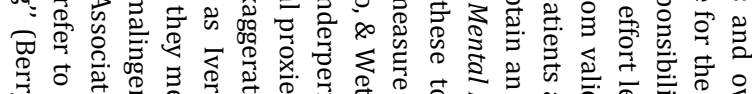

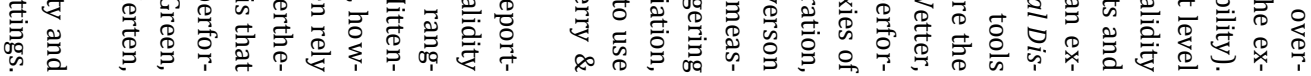




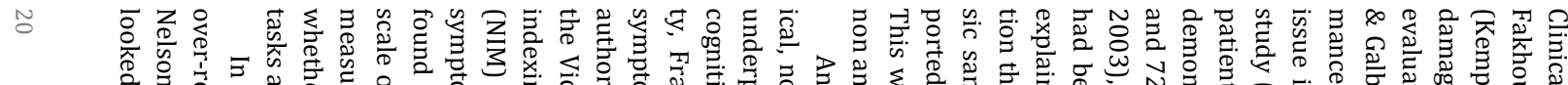

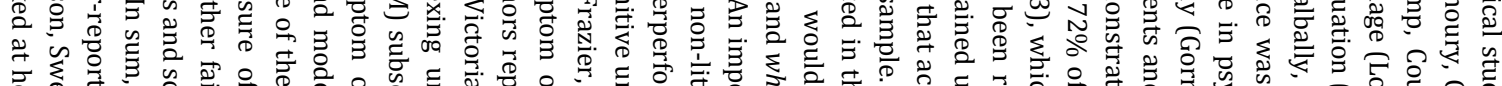

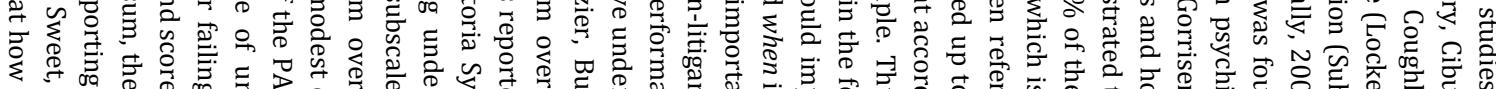

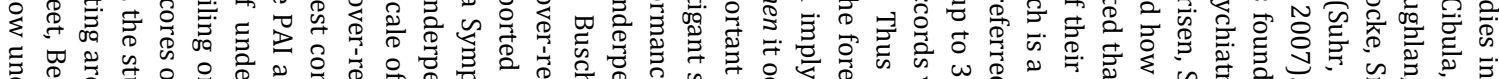

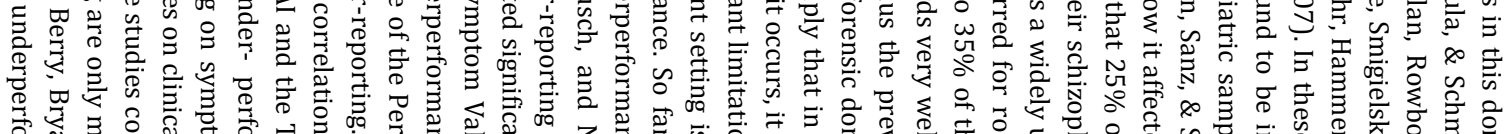

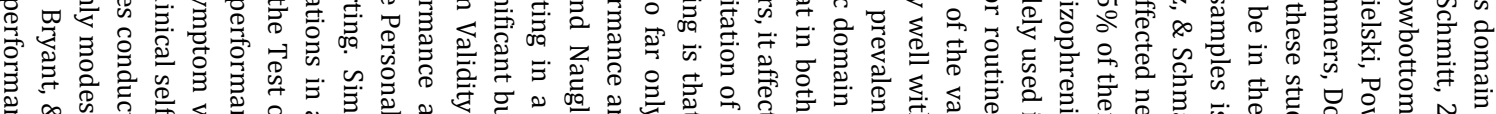

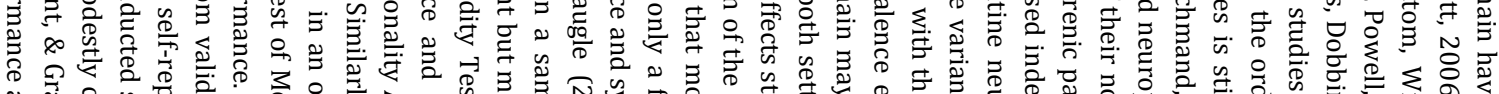

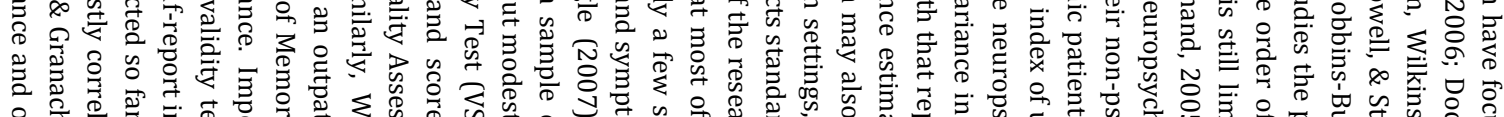

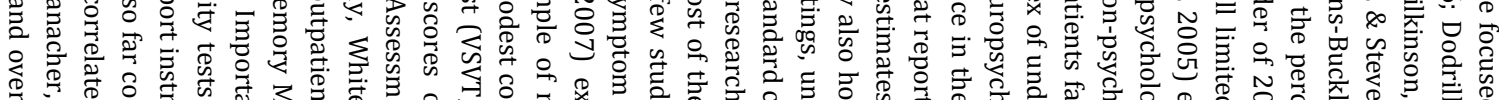

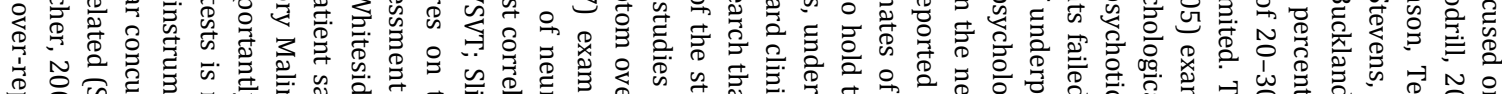

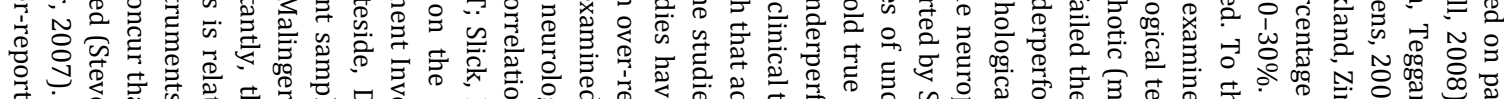

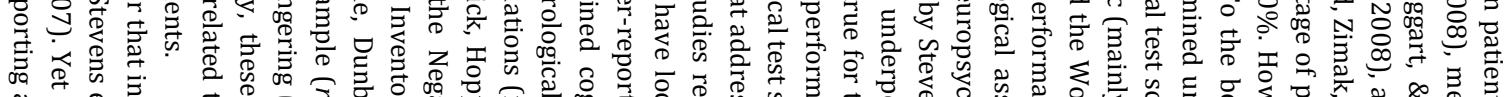

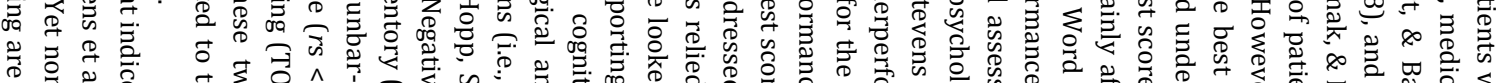

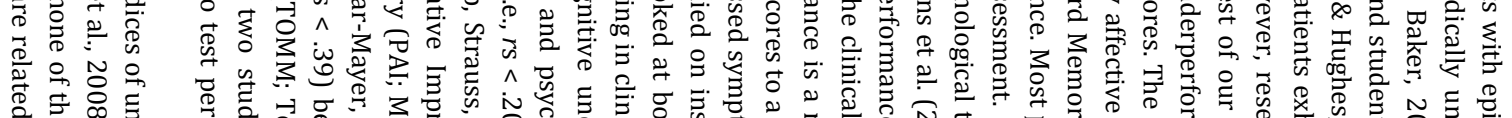

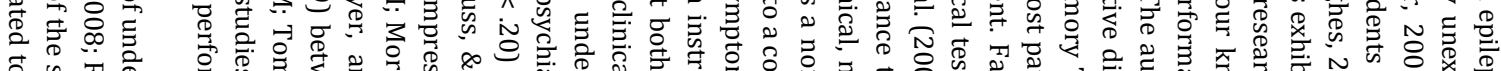

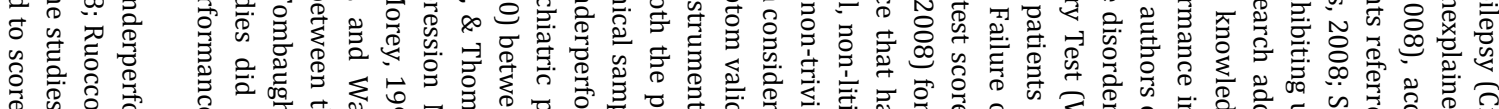

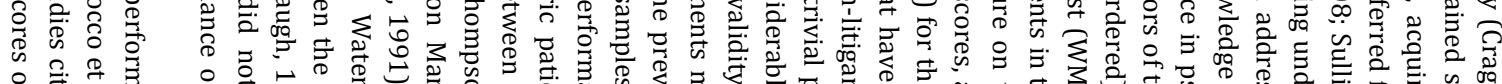

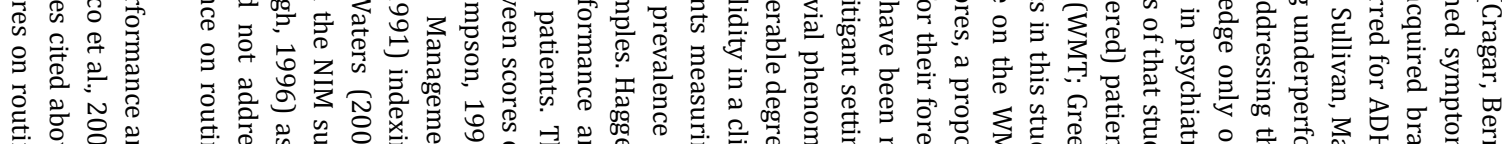

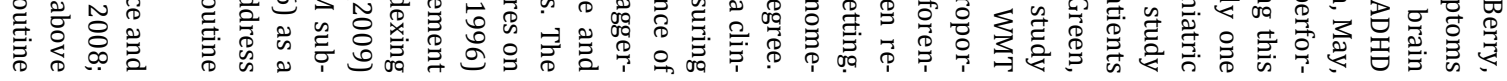

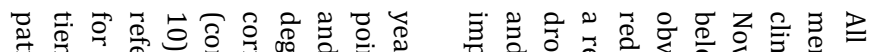

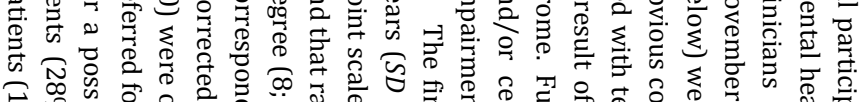

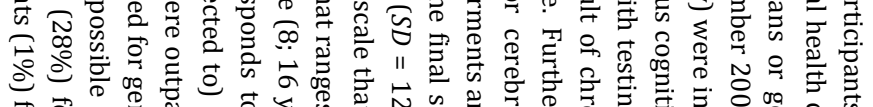

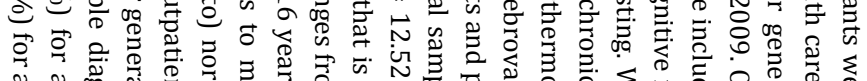

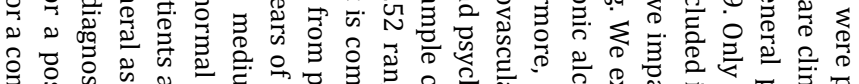

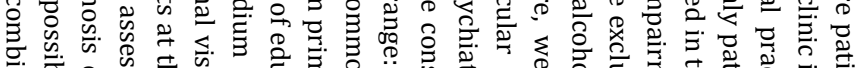

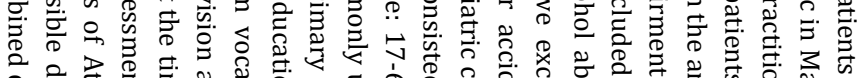

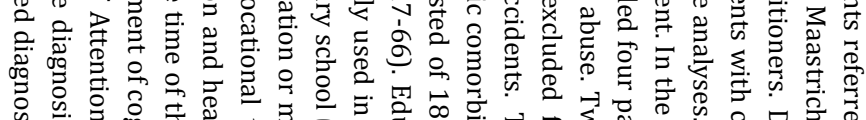

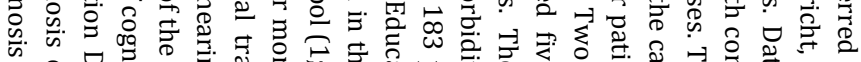

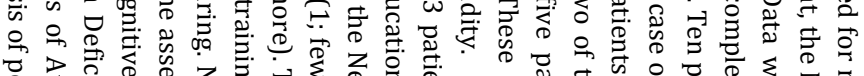

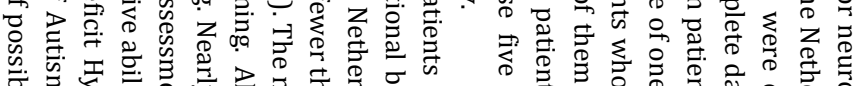

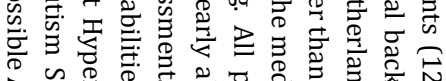

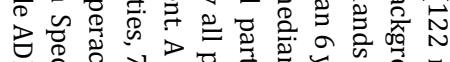

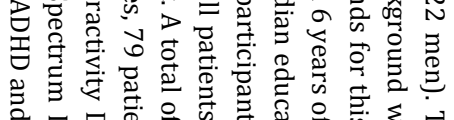

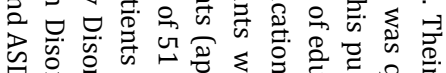

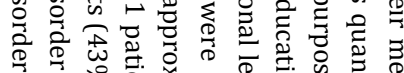

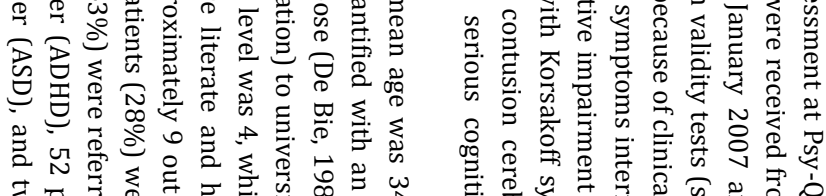

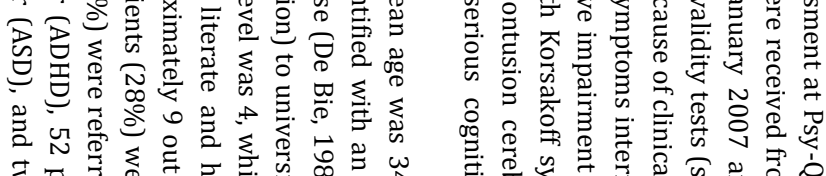

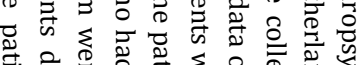

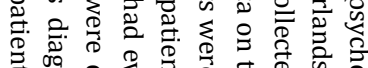

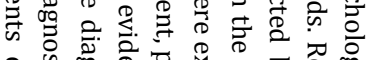

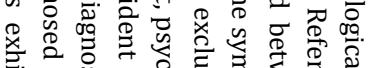

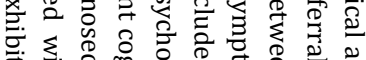

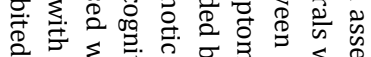

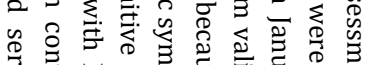

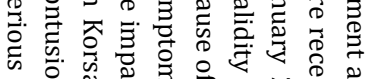

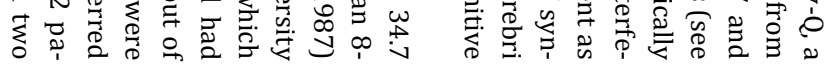

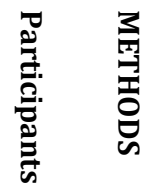

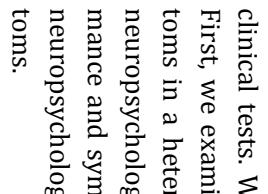

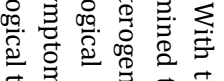

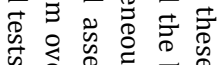

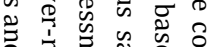

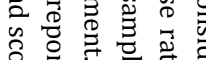

익

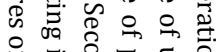

今

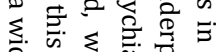

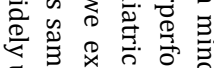

疍

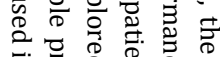

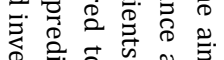
产它 क

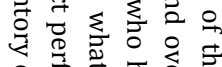

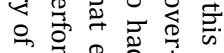

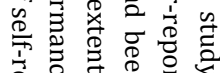

官

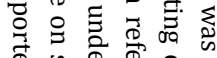

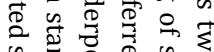

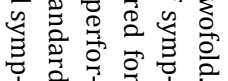




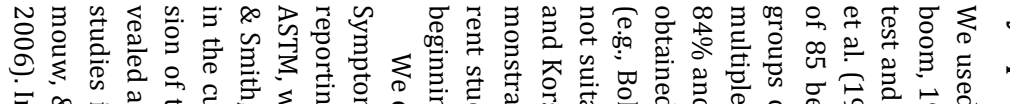

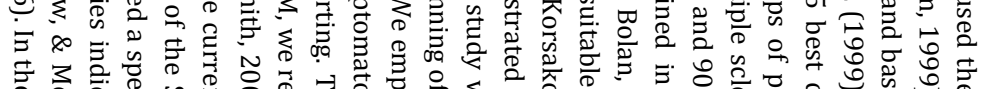

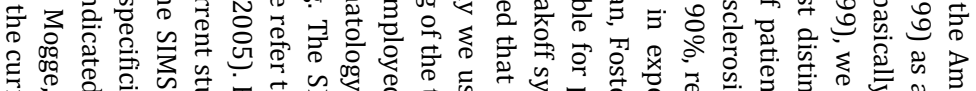

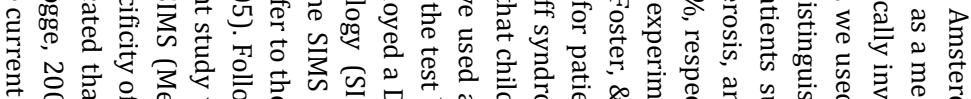

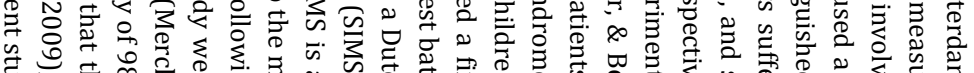

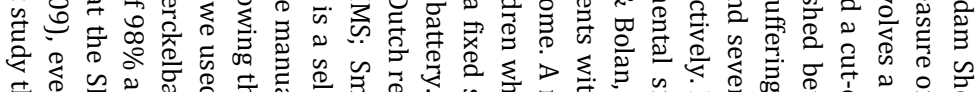

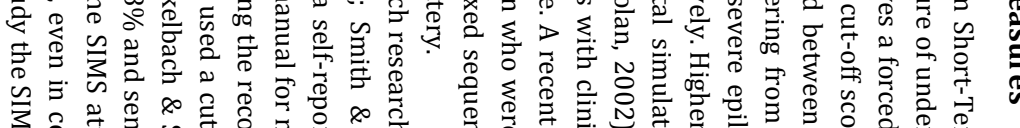

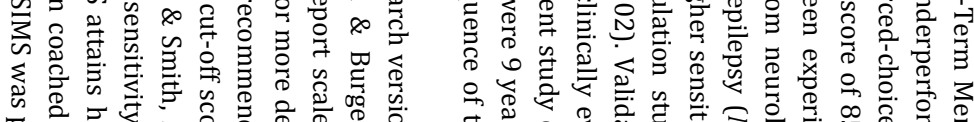

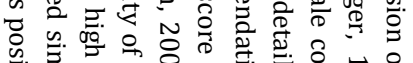

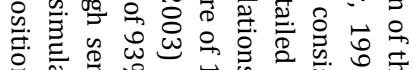

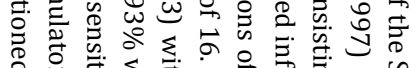

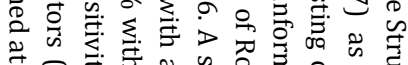

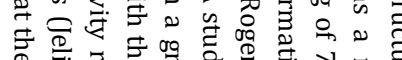
०

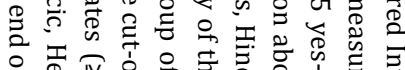

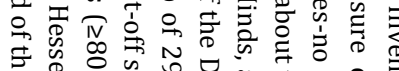

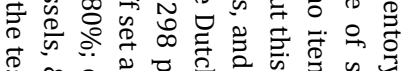

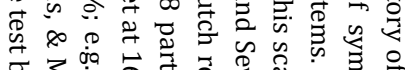

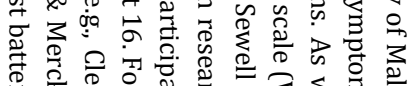

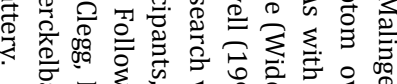

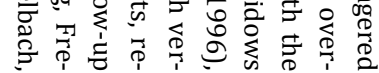

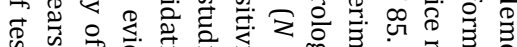
के

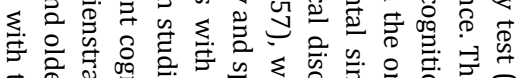

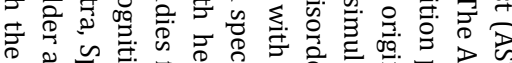

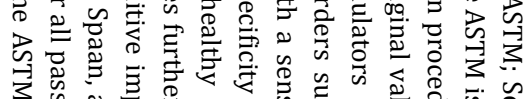
了.

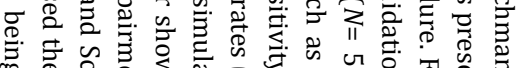

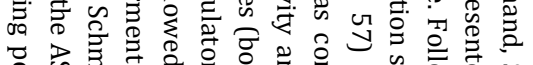

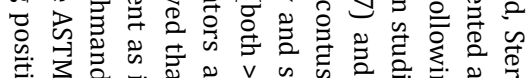

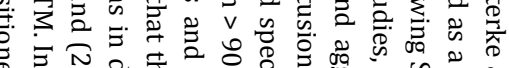

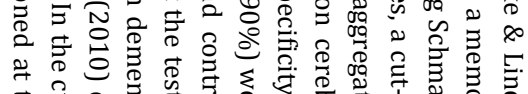

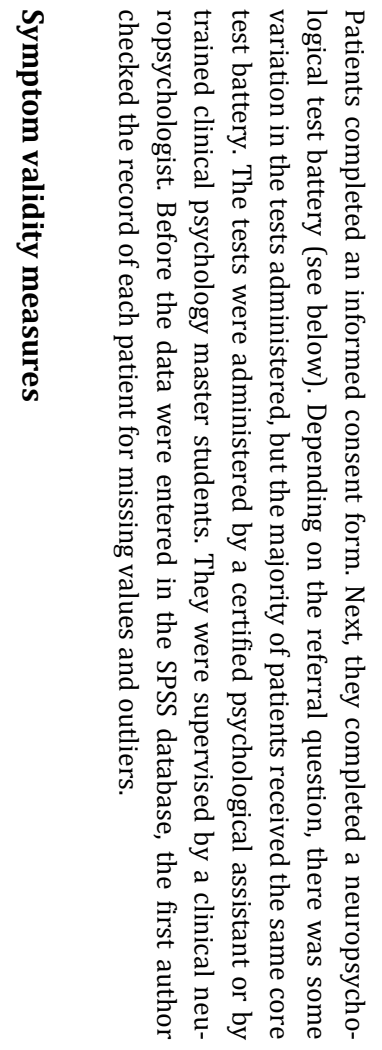
б 


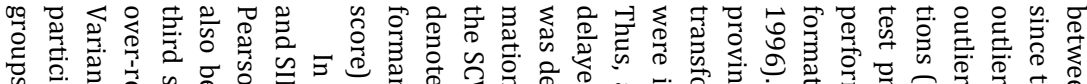

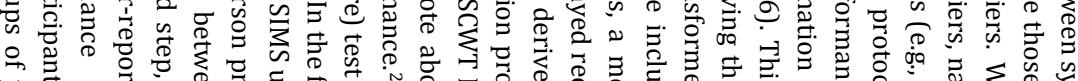

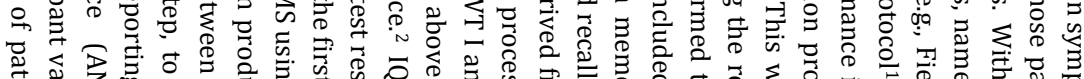

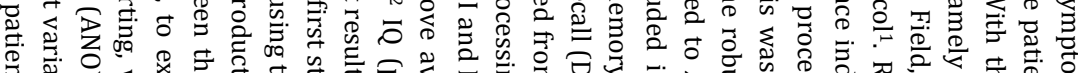

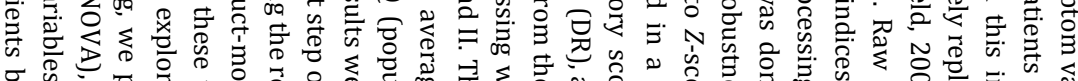

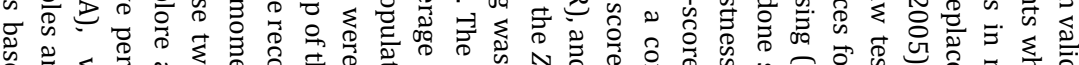

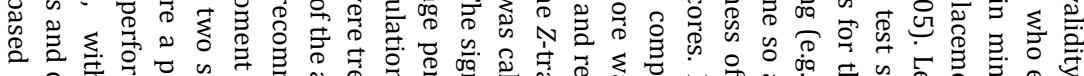

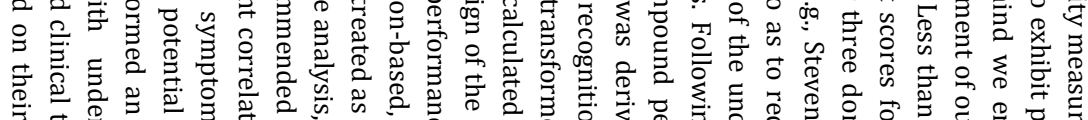

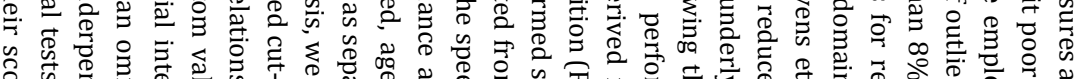

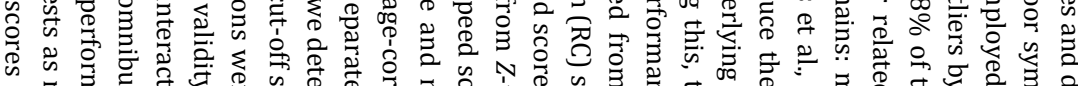

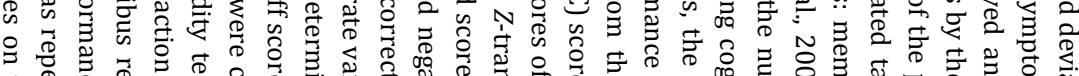

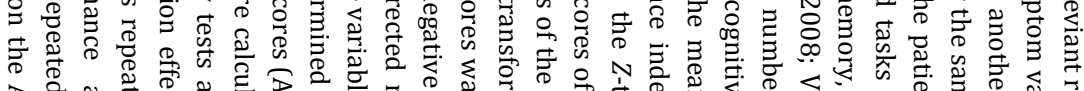

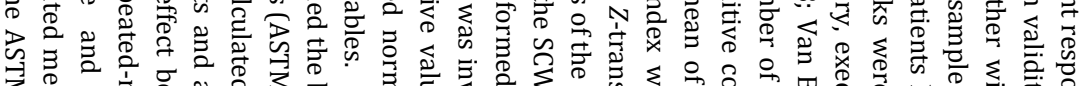

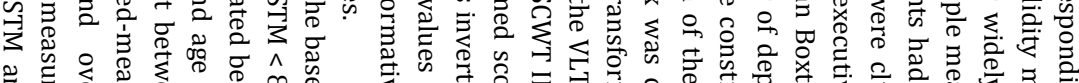

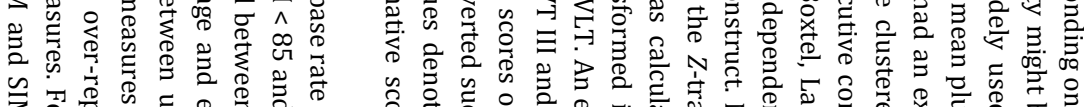

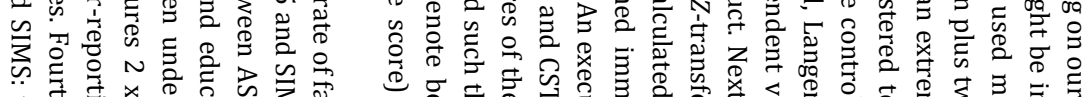

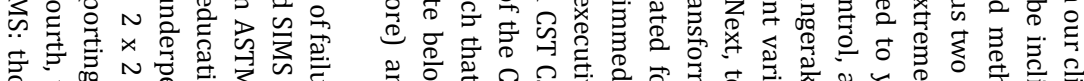

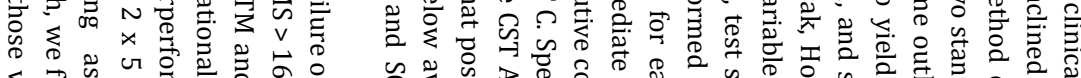

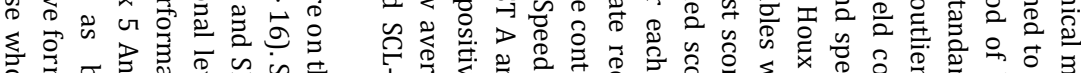

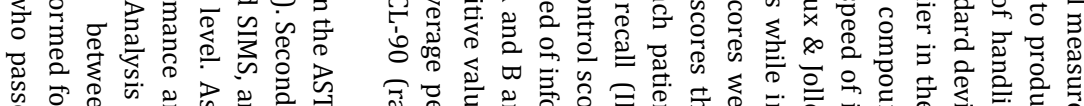

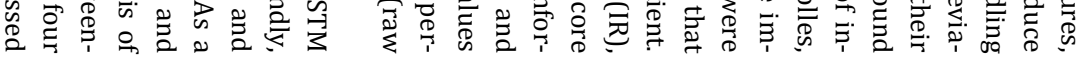

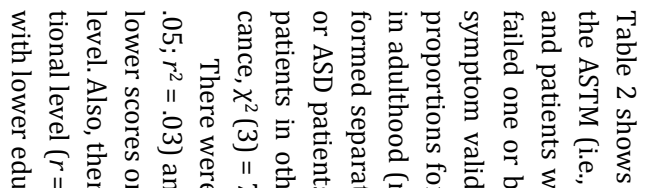
ming

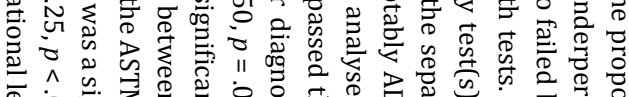

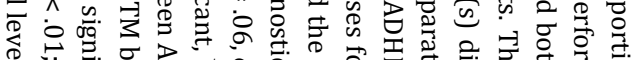
Hing

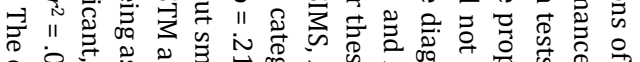

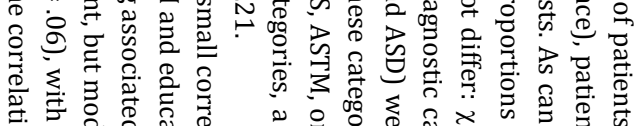

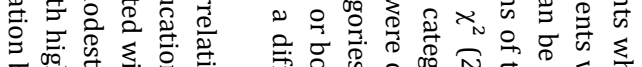

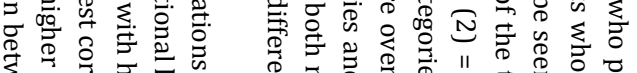
tin

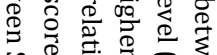

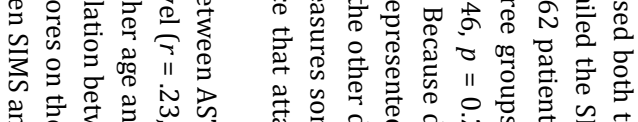
ह. \%马 总

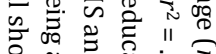

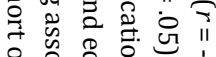

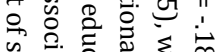
品.

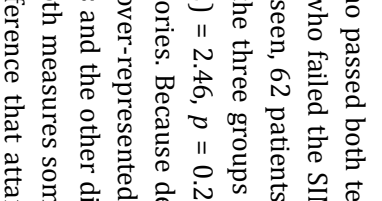

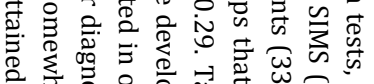

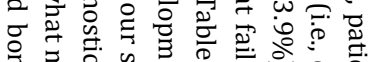

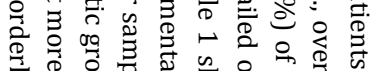

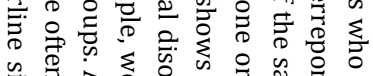

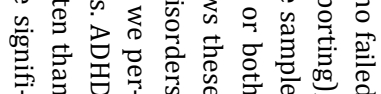

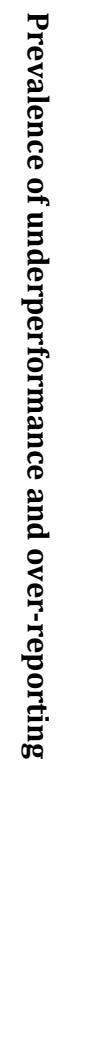

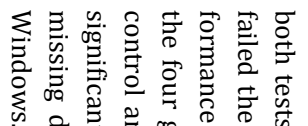
फ

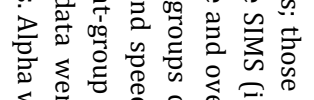

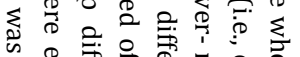

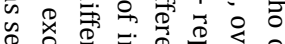

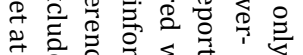

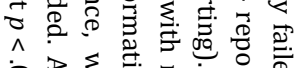

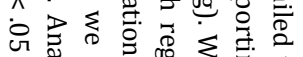

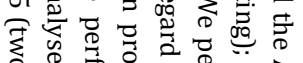

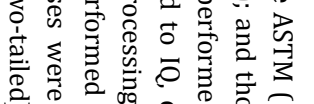
¿

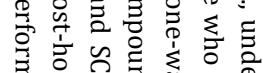

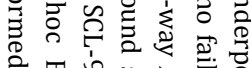

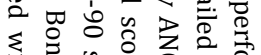

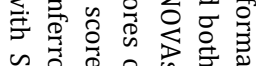

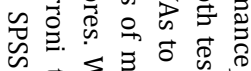

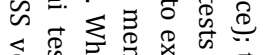

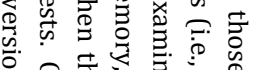

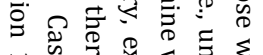

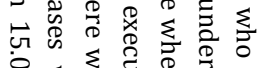

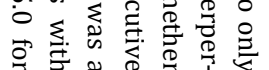


Table 1 DSM-IV-TR diagnoses (percentages between parentheses) in the sample $(N=183)$ and number of patients failing the ASTM and SIMS

\begin{tabular}{|c|c|c|c|c|c|c|c|c|}
\hline \multirow[b]{2}{*}{ ADHD } & \multicolumn{2}{|c|}{ Primary diagnosis } & \multicolumn{2}{|c|}{ Secondary diagnosis } & \multicolumn{2}{|c|}{ Fail ASTM } & \multicolumn{2}{|c|}{ Fail SIMS } \\
\hline & 56 & $(30.6 \%)$ & 4 & $(2.2 \%)$ & 8 & $(14 \%)$ & 8 & $(14 \%)$ \\
\hline ASD & 25 & $(13.7 \%)$ & 1 & $(0.5 \%)$ & 4 & $(16 \%)$ & 4 & $(16 \%)$ \\
\hline Affective disorders & 34 & $(18.6 \%)$ & 40 & $(21.9 \%)$ & 8 & $(24 \%)$ & 7 & $(21 \%)$ \\
\hline Psychotic Disorder & 8 & $(4.4 \%)$ & 1 & $(0.5 \%)$ & 2 & $(25 \%)$ & 3 & $(38 \%)$ \\
\hline Cognitive disorder NOS & 7 & $(3.8 \%)$ & 8 & $(4.4 \%)$ & 4 & $(57 \%)$ & 4 & $(57 \%)$ \\
\hline Personality Disorders & 16 & $(8.7 \%)$ & 3 & $(1.6 \%)$ & 5 & $(31 \%)$ & 6 & $(38 \%)$ \\
\hline Abuse/Dependence of substances & 11 & $(6.0 \%)$ & 14 & $(7.7 \%)$ & 2 & $(18 \%)$ & 2 & $(18 \%)$ \\
\hline Other psychiatric disorders & 13 & $(7.1 \%)$ & 18 & $(9.8 \%)$ & 4 & $(31 \%)$ & 3 & $(23 \%)$ \\
\hline Postponed diagnosis & 5 & $(2.7 \%)$ & 4 & $(2.2 \%)$ & 2 & $(40 \%)$ & 1 & $(20 \%)$ \\
\hline No diagnosis & 8 & $(4.4 \%)$ & 90 & $(49.2 \%)$ & 0 & $(0 \%)$ & 0 & $(0 \%)$ \\
\hline
\end{tabular}

Notes: ASTM = Amsterdam Short Term Memory test; SIMS = Structured Inventory of Malingered Symptomatology; ADHD = Attention Deficit Hyperactivity Disorder; ASD = Autism Spectrum Disorders; NOS = Not Otherwise Specified. 


\begin{tabular}{|c|c|c|c|c|c|c|c|c|c|}
\hline Measure & $\begin{array}{l}\text { Number of } \\
\text { Patients }\end{array}$ & $\begin{array}{l}\text { Group 1 } \\
\text { Passed } \\
\text { both }\end{array}$ & $\begin{array}{l}\text { Group } 2 \\
\text { Failed only } \\
\text { ASTM }\end{array}$ & $\begin{array}{l}\text { Group } 3 \\
\text { Failed only } \\
\text { SIMS }\end{array}$ & $\begin{array}{l}\text { Group } 4 \\
\text { Failed } \\
\text { both }\end{array}$ & $\mathbf{F}$ & $\begin{array}{l}p \text { - } \\
\text { value }\end{array}$ & $\begin{array}{l}\text { Eta } \\
\text { squared }\end{array}$ & $\begin{array}{l}\text { Significant group comparisons } \\
\text { (Bonferroni corrected) }\end{array}$ \\
\hline IQ & 180 & $\begin{array}{l}95.60 \\
(16,16)\end{array}$ & $\begin{array}{l}92.08 \\
(19.81)\end{array}$ & $\begin{array}{l}84.83 \\
(14.28)\end{array}$ & $\begin{array}{l}78.86 \\
(14.48)\end{array}$ & 6.36 & .00 & .10 & $3,4<1$ \\
\hline $\begin{array}{l}\text { Compound score } \\
\text { Memory }\end{array}$ & 180 & $\begin{array}{l}.19 \\
(.80)\end{array}$ & $\begin{array}{l}-.60 \\
(1.00)\end{array}$ & $\begin{array}{l}-.22 \\
(.81)\end{array}$ & $\begin{array}{l}-.25 \\
(.85)\end{array}$ & 6.75 & .00 & .10 & $2<1$ \\
\hline $\begin{array}{l}\text { Compound score } \\
\text { Speed }\end{array}$ & 161 & $\begin{array}{l}.14 \\
(.69)\end{array}$ & $\begin{array}{l}-.21 \\
(.90)\end{array}$ & $\begin{array}{l}-.31 \\
(.92)\end{array}$ & $\begin{array}{l}-.46 \\
(1.14)\end{array}$ & 4.00 & .01 & .07 & n.s. \\
\hline $\begin{array}{l}\text { Compound score } \\
\text { Executive }\end{array}$ & 112 & $\begin{array}{l}1.46 \\
(.83)\end{array}$ & $\begin{array}{l}-.38 \\
(1.11)\end{array}$ & $\begin{array}{l}-.32 \\
(.84)\end{array}$ & $\begin{array}{l}-.23 \\
(.79)\end{array}$ & 3.48 & .02 & .06 & n.s. \\
\hline $\begin{array}{l}\text { SCL-90 raw total } \\
\text { score }\end{array}$ & 112 & $\begin{array}{l}159.72 \\
(37.73)\end{array}$ & $\begin{array}{l}186.13 \\
(61.16)\end{array}$ & $\begin{array}{l}262.85 \\
(71.99)\end{array}$ & $\begin{array}{l}271.89 \\
(61.54)\end{array}$ & 28.37 & .00 & .44 & $\begin{array}{l}3,4>1 \\
3,4>2\end{array}$ \\
\hline
\end{tabular}

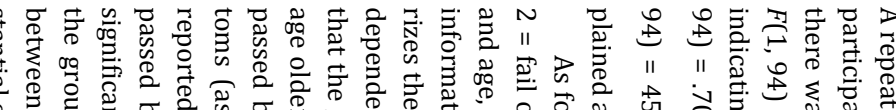
బ)

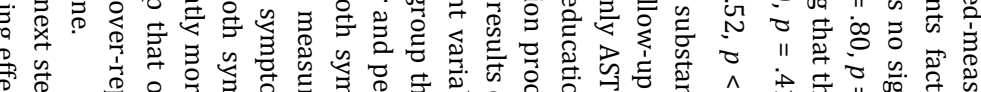

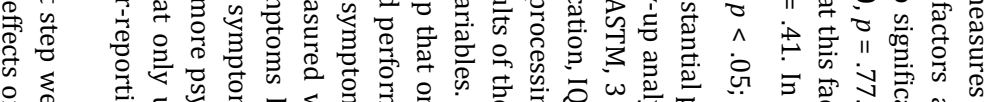

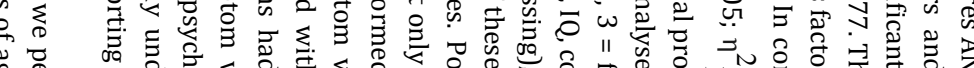

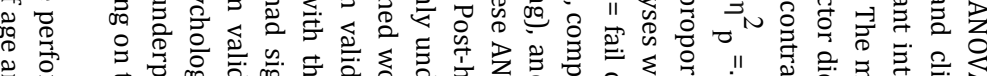

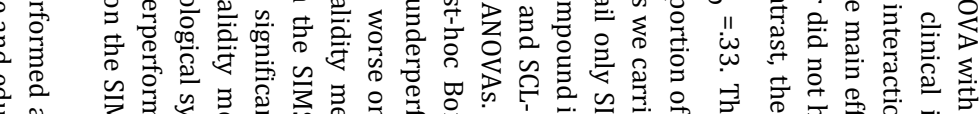

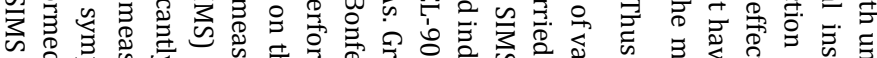

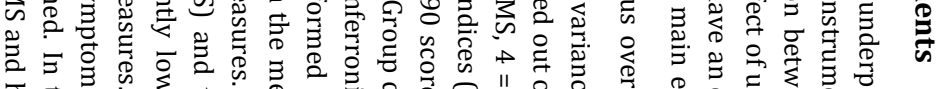

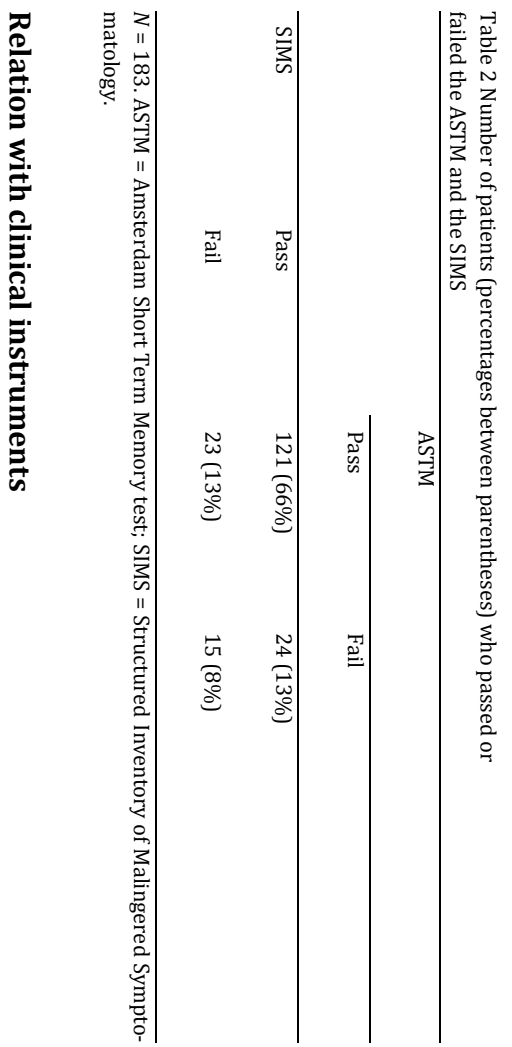




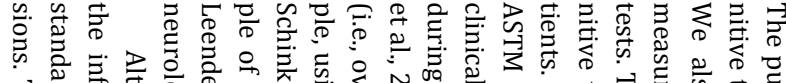

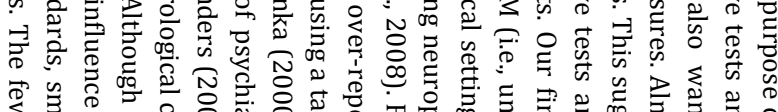

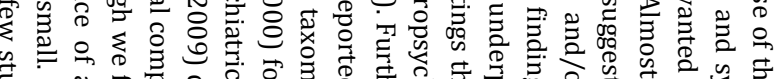

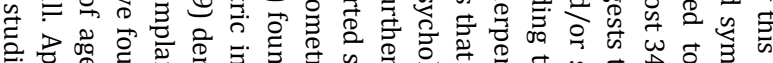

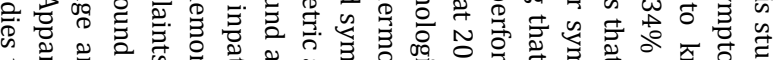

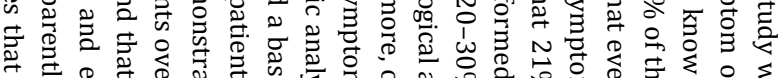

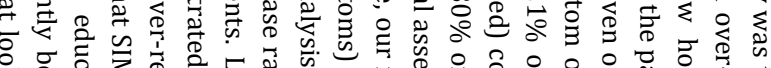

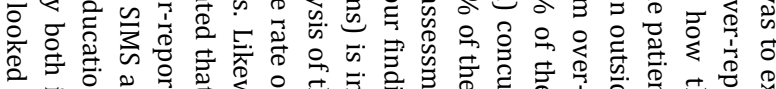

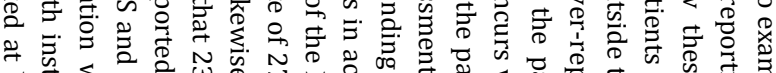

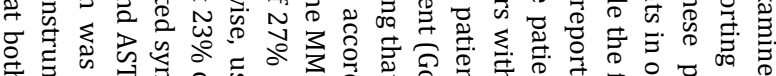

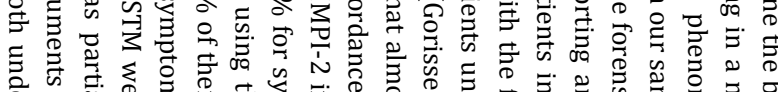

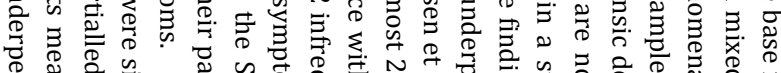

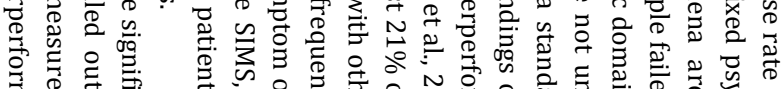

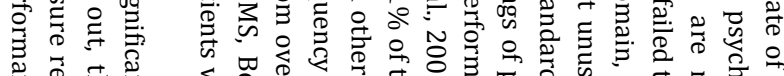

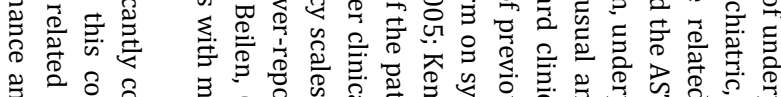

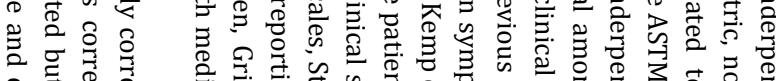

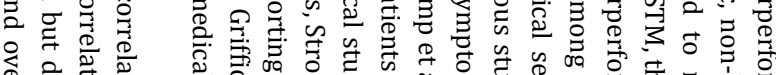

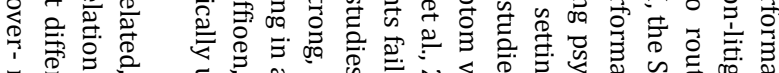

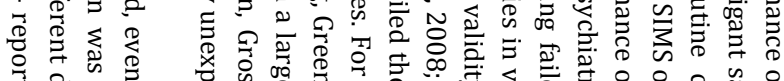

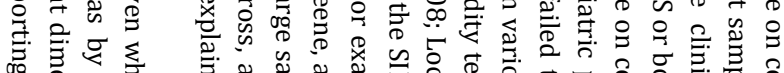

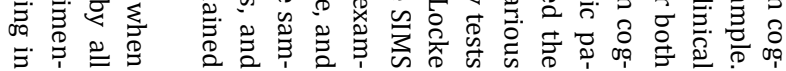

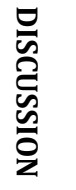

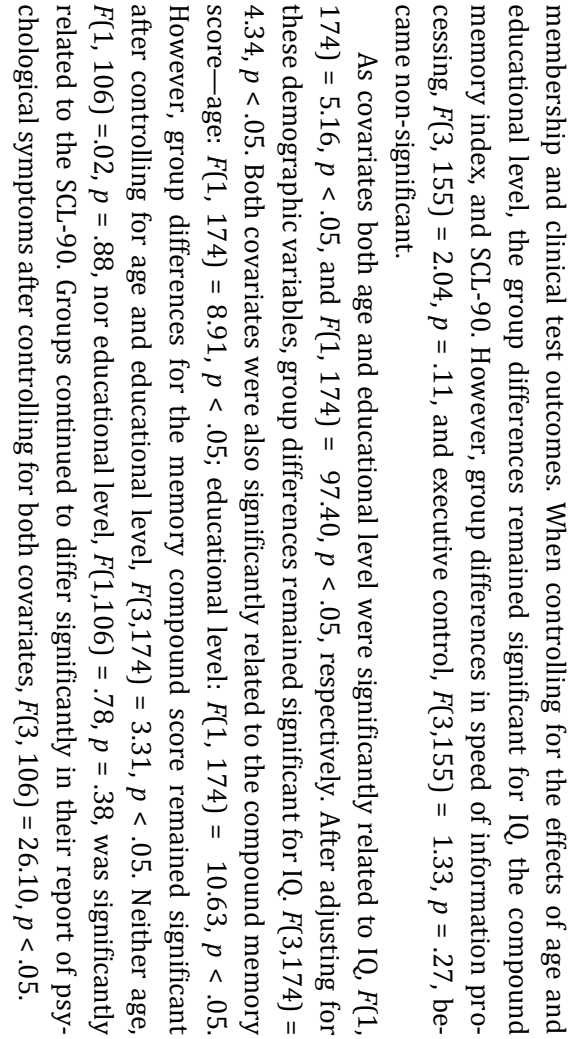

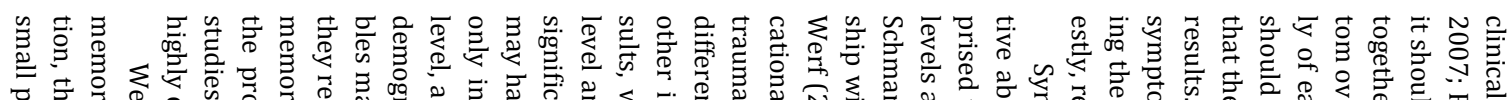

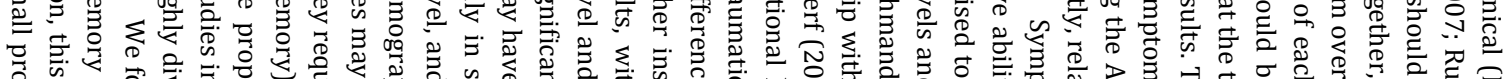

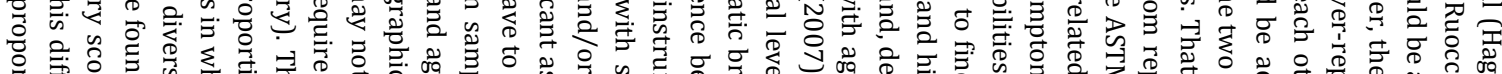

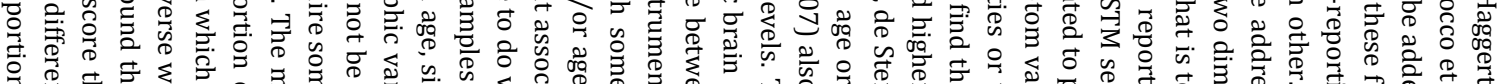

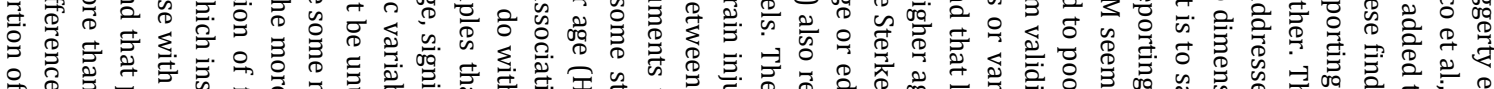

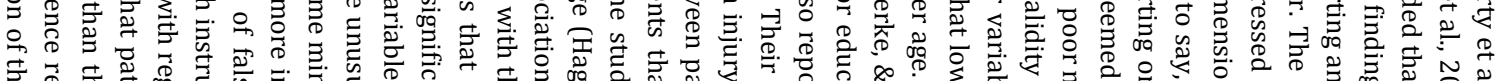

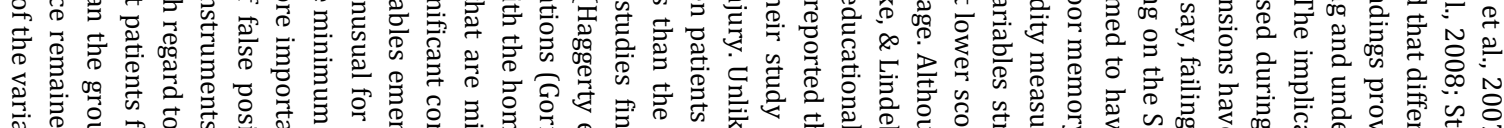

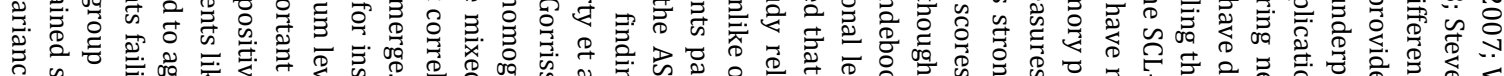

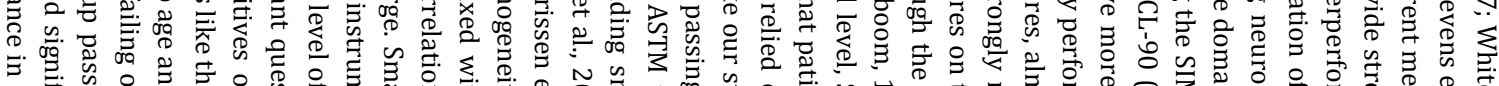

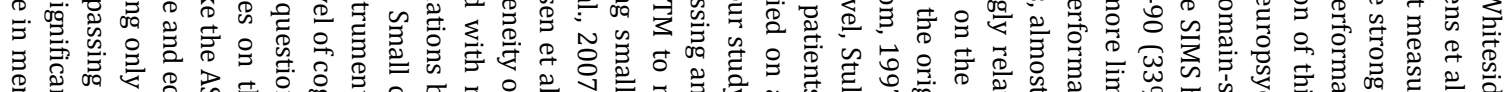

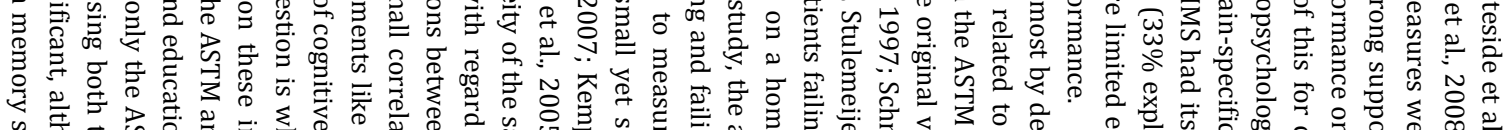

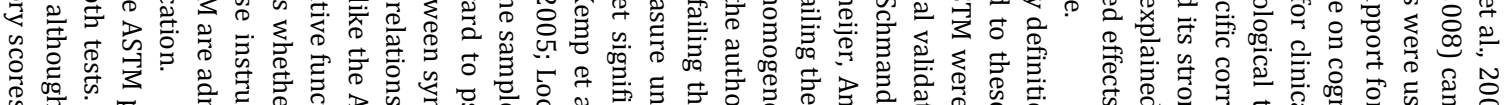

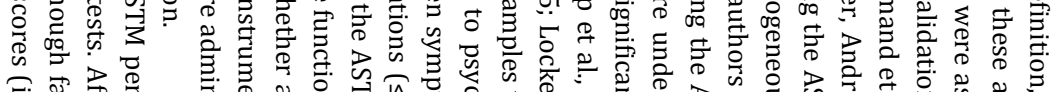

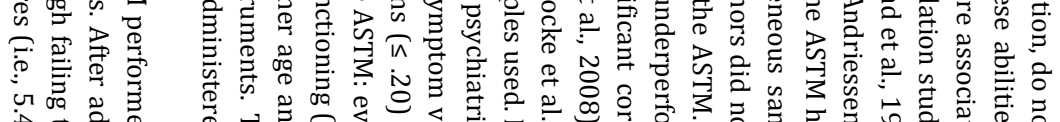

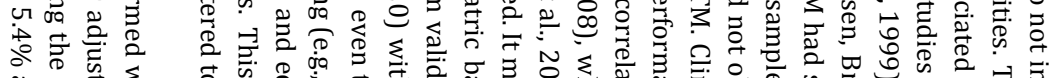

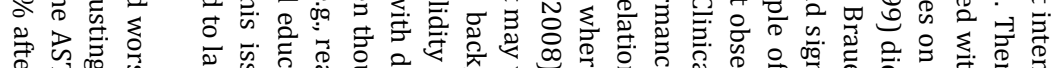

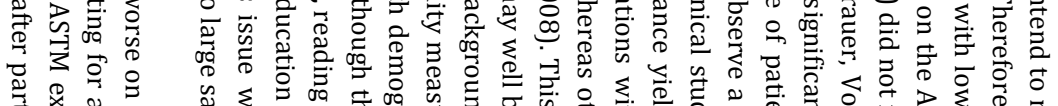

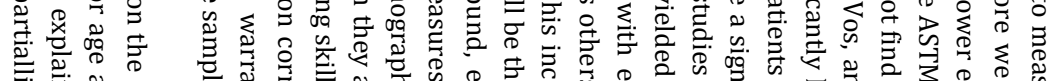

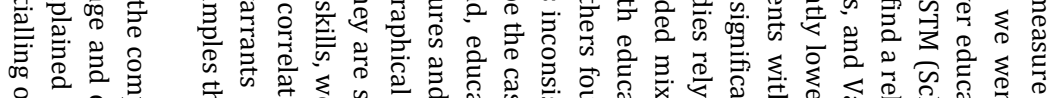

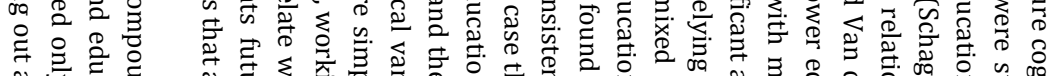

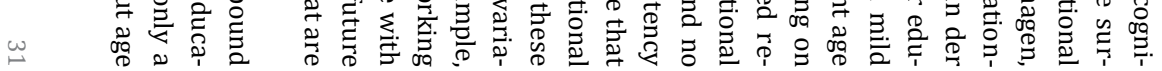

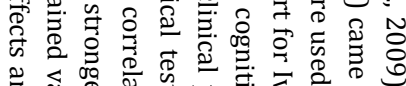

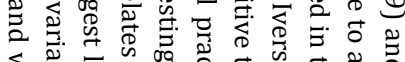

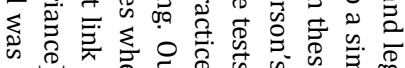
ट

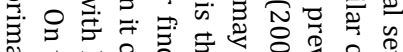

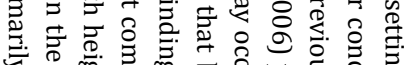

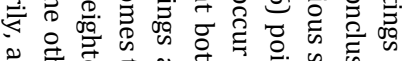

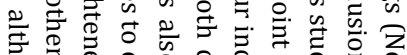

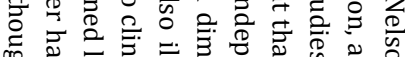

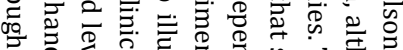

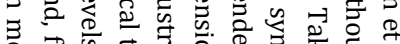

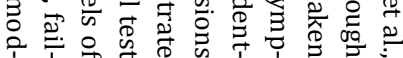




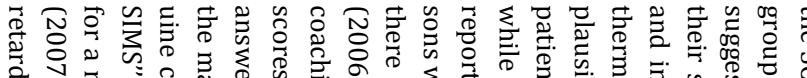

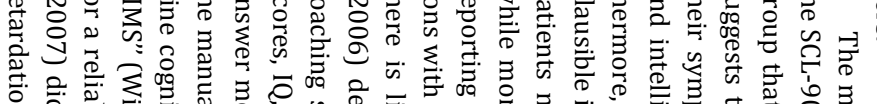

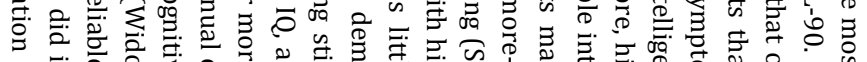

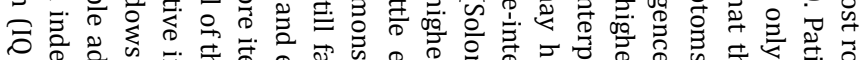

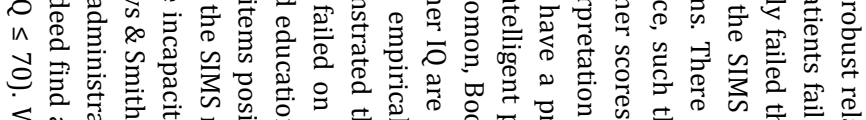

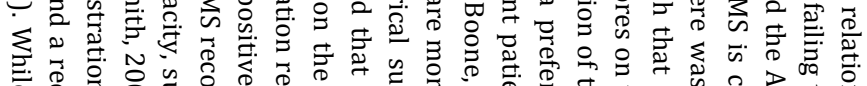

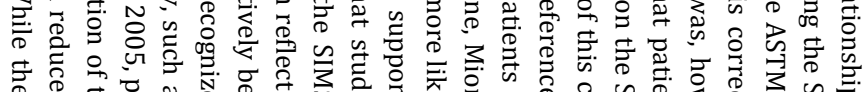

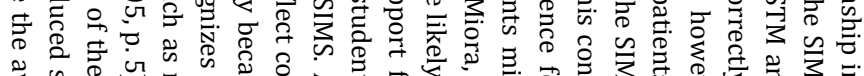

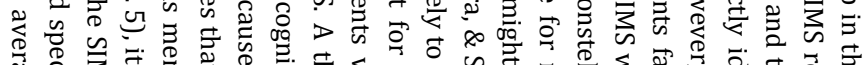

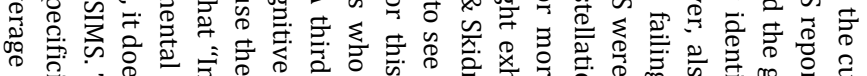

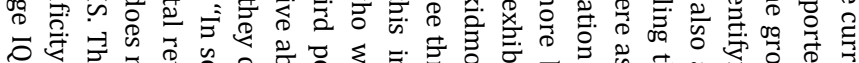

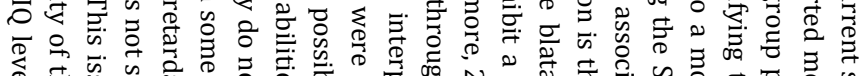

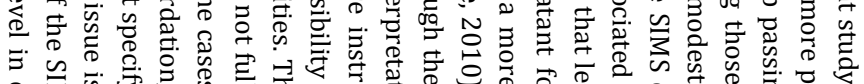

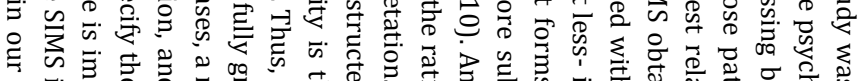

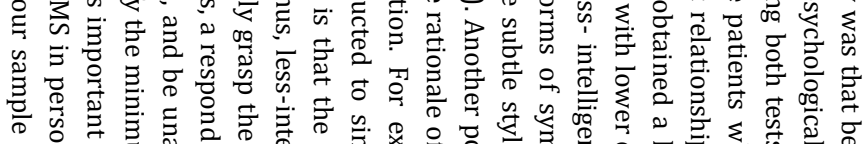

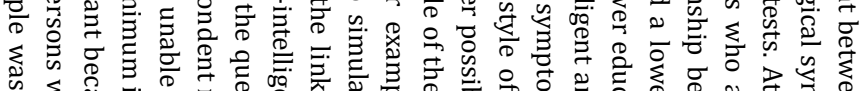

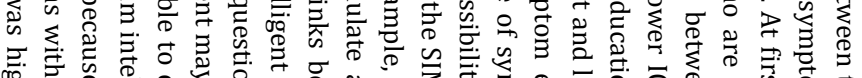

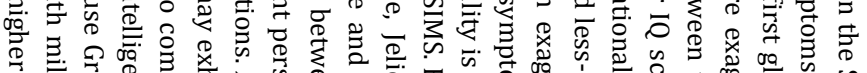

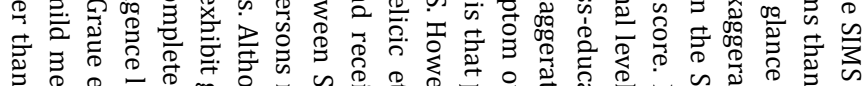

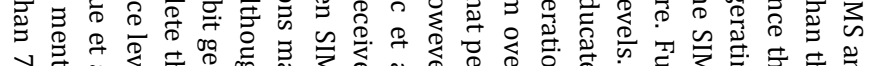

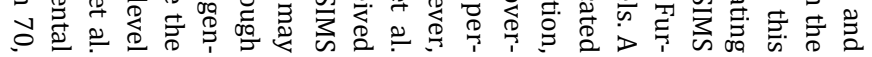

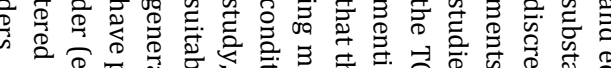

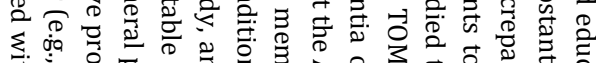

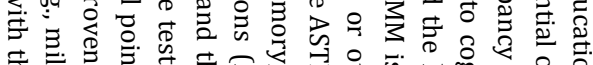

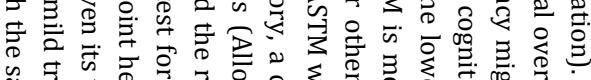

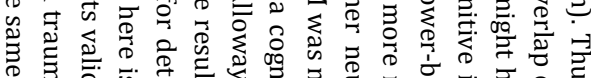

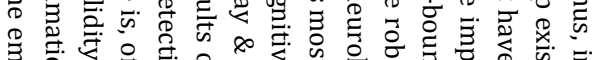

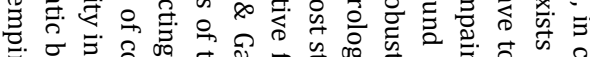

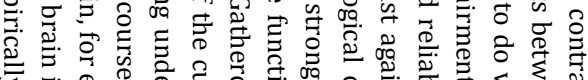

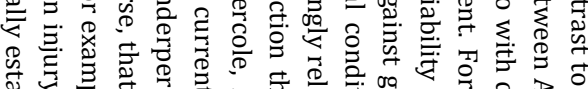

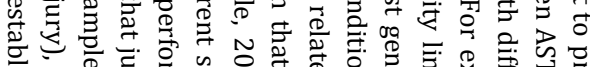

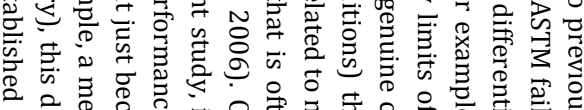
응

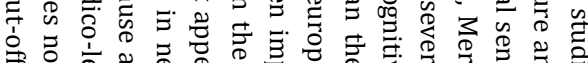

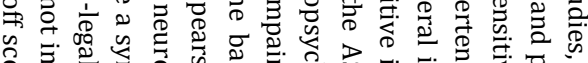

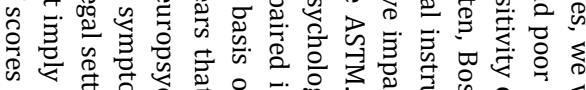

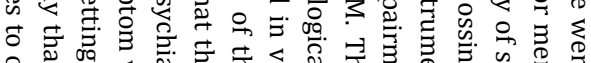

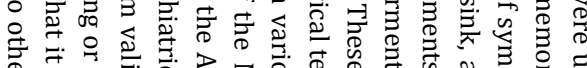

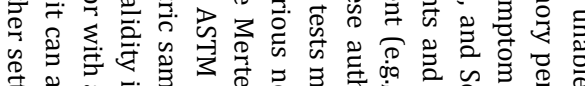

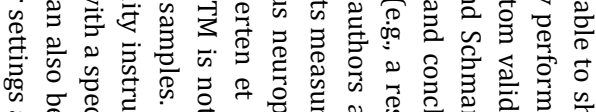

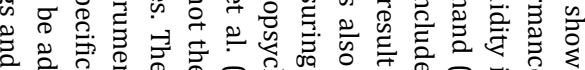

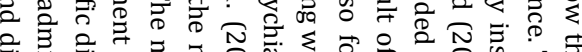

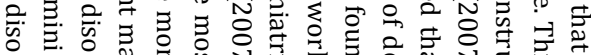

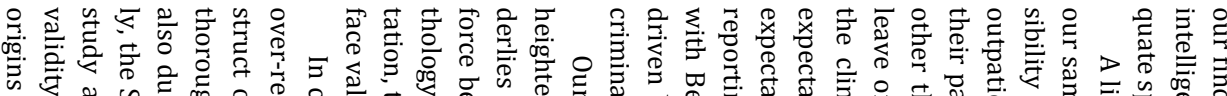

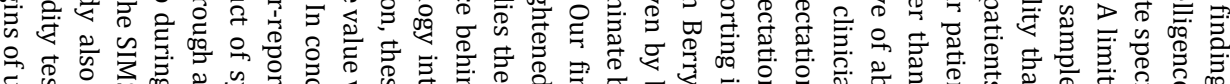

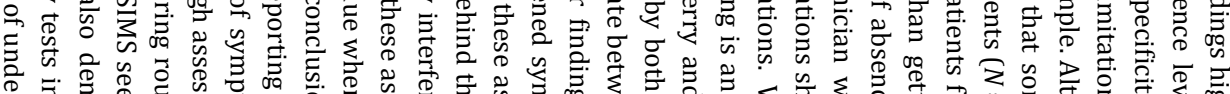

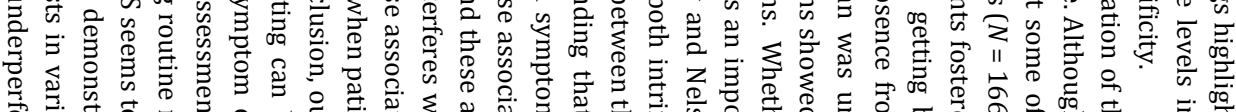

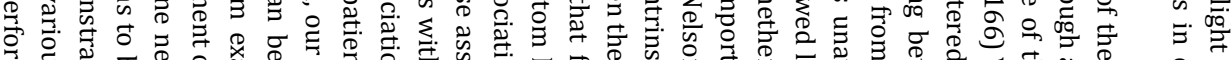

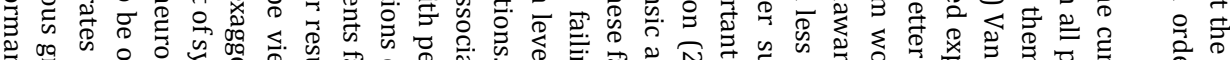

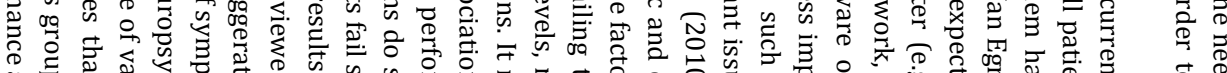

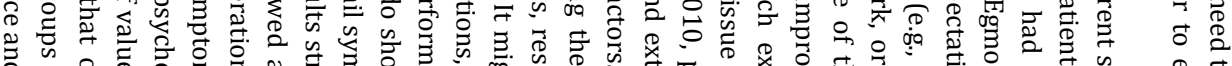

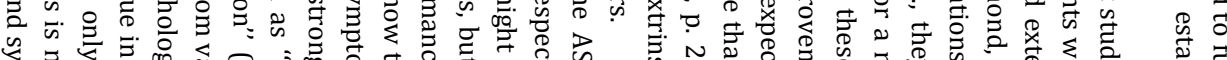

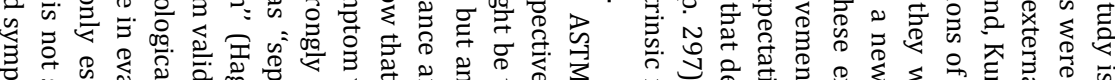

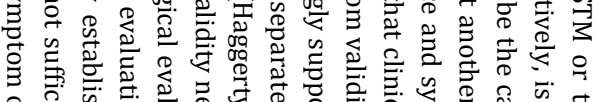

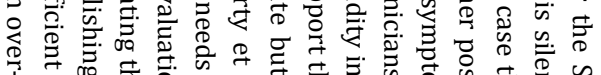

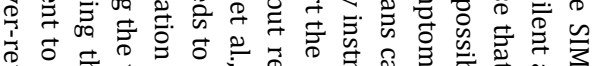

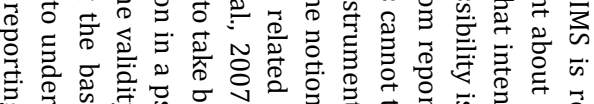

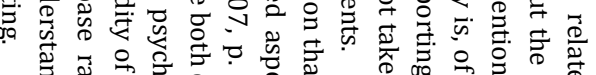

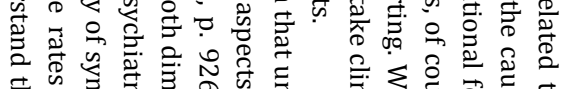

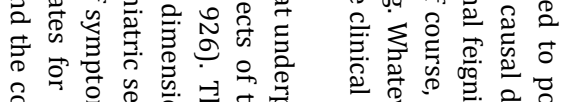

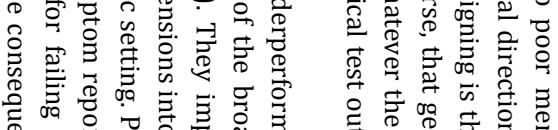

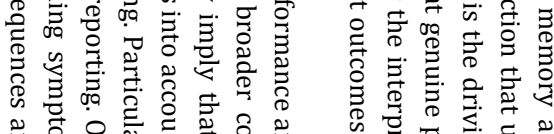

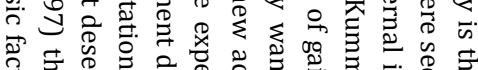

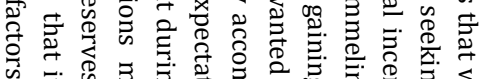

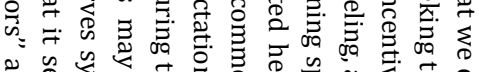

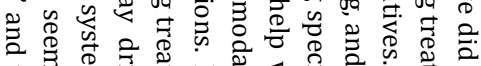

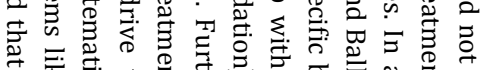

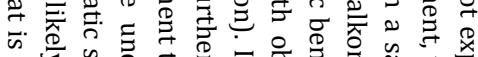

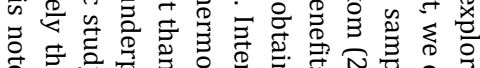

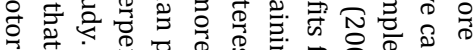

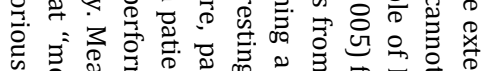

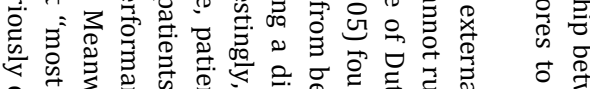

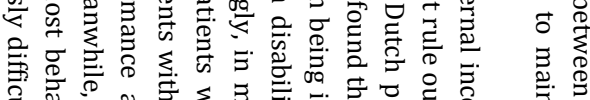
产空.

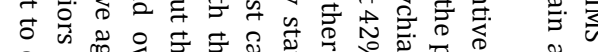

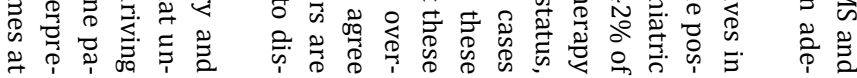

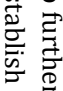

苋 

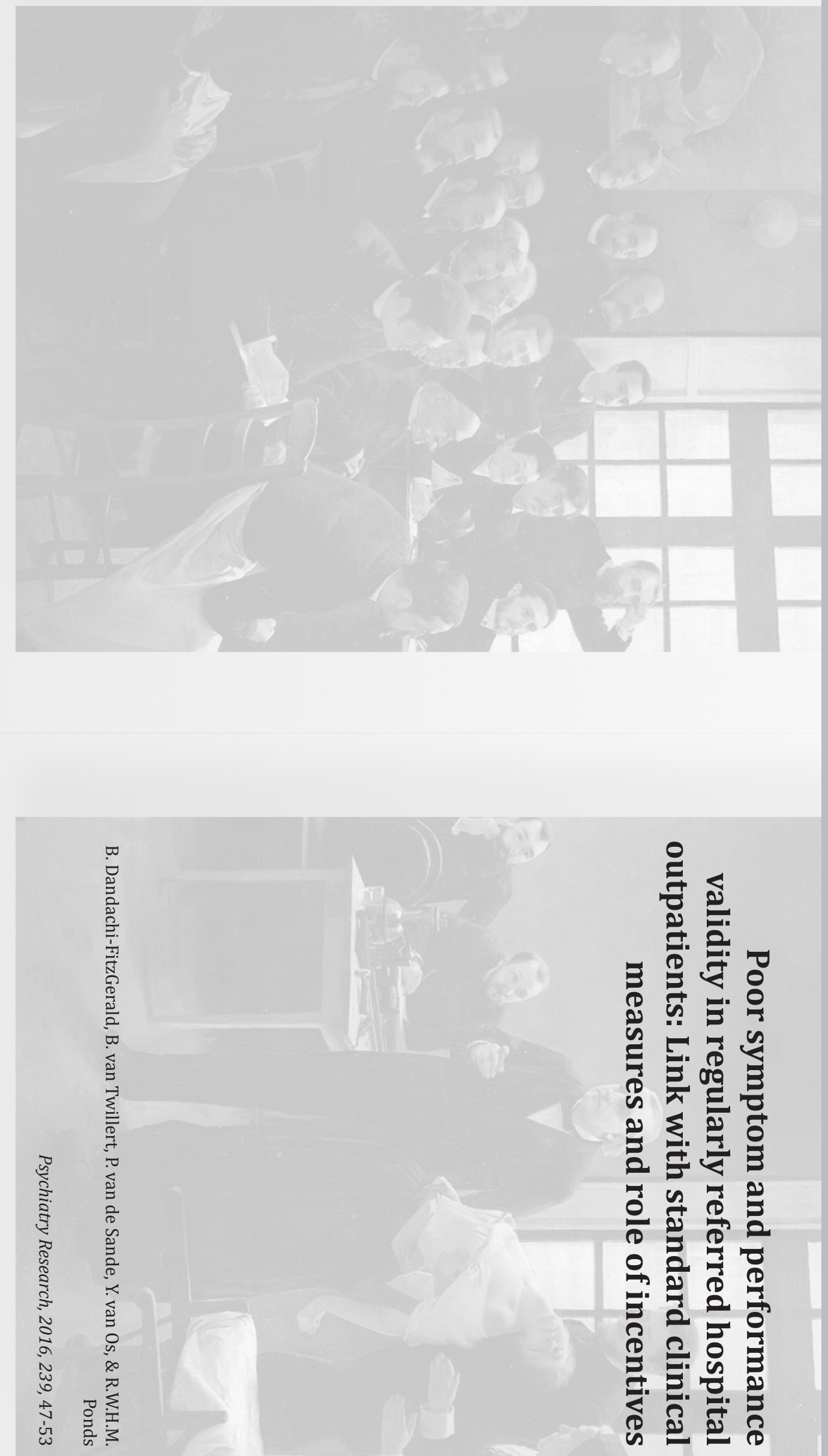

$\underbrace{0}_{0}$ 


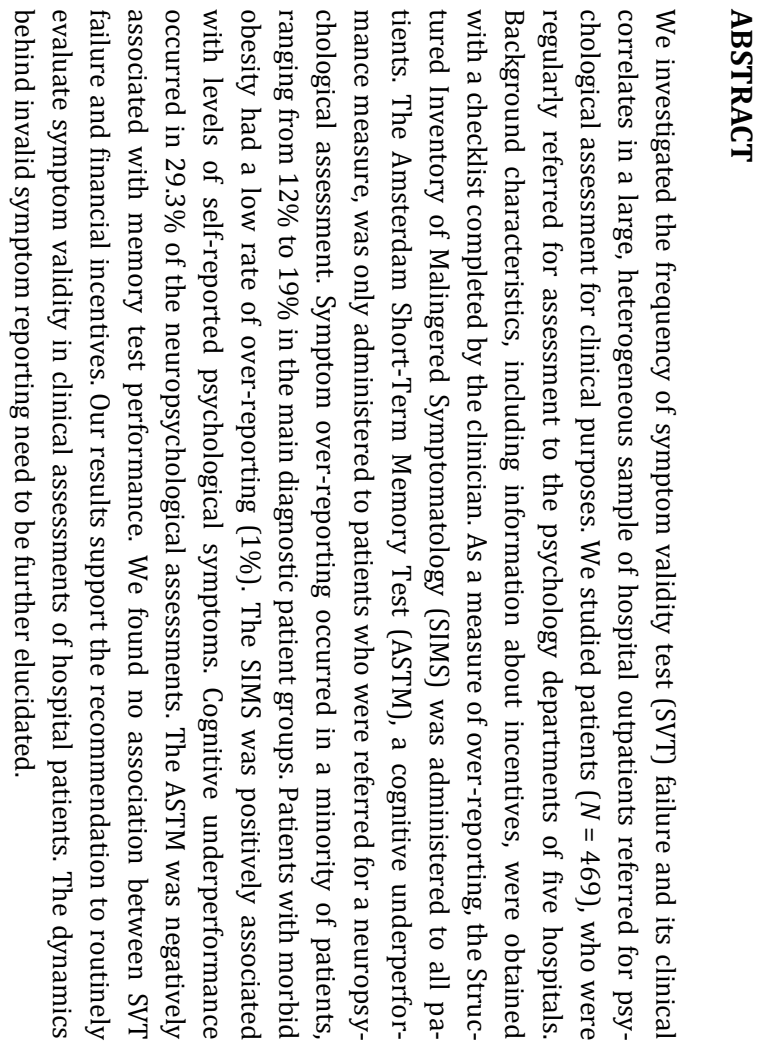

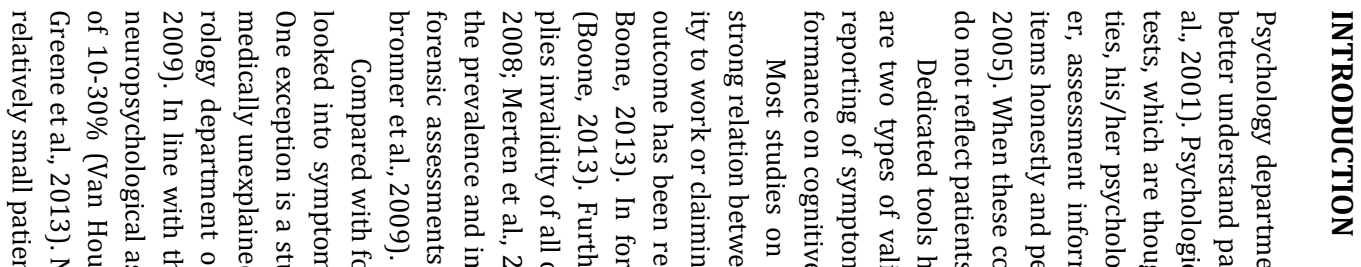

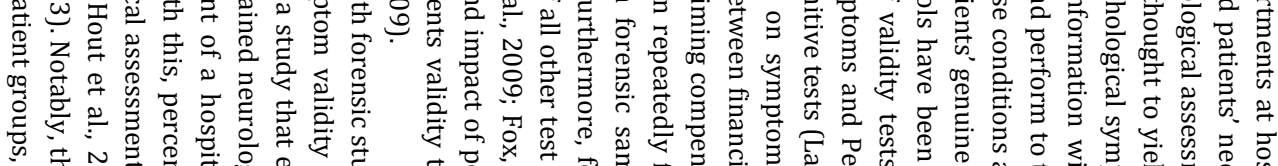

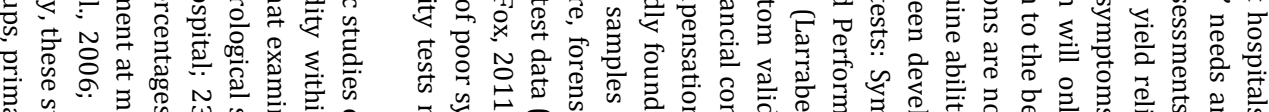

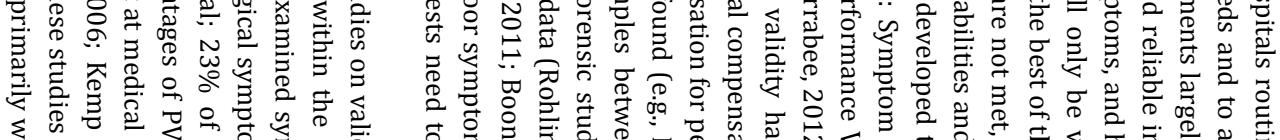

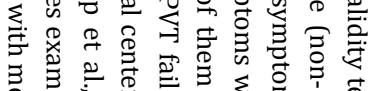

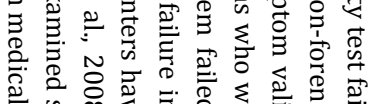

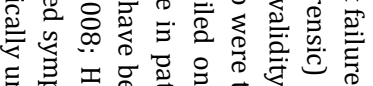
集

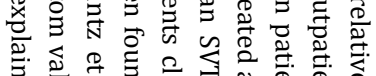

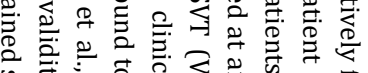

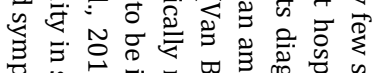

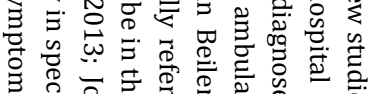

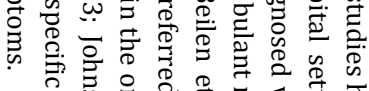

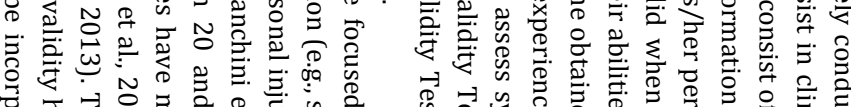

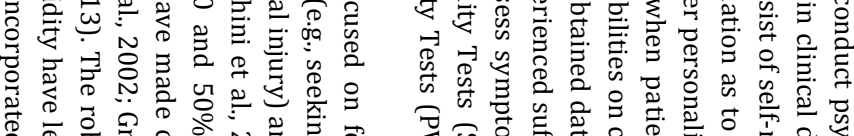

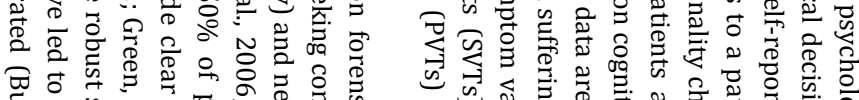

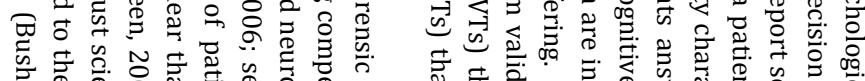

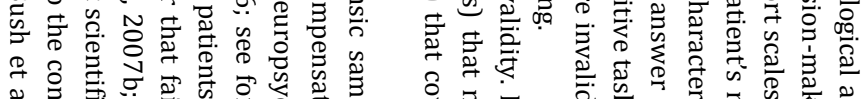

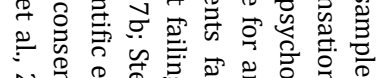

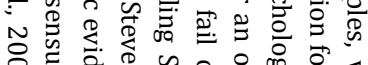

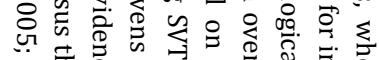

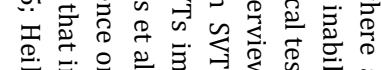

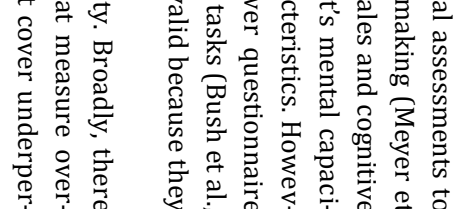




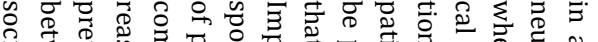

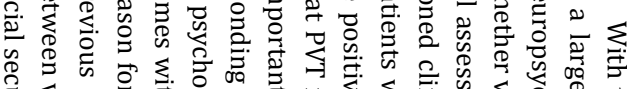
龸.

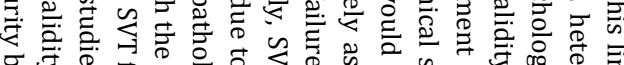

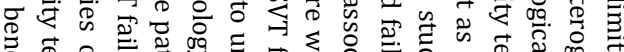

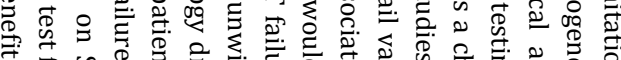

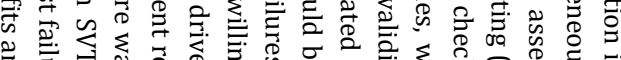

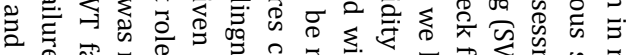

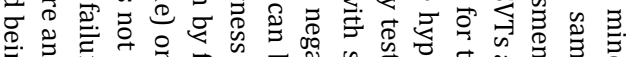

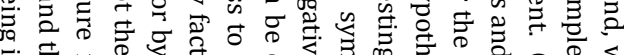
छे

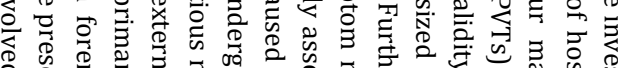

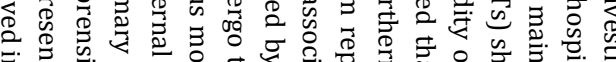

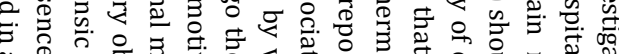

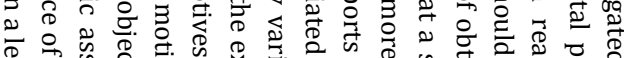

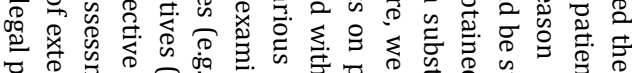

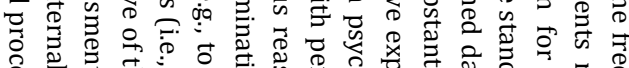

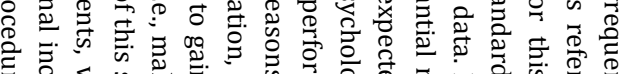

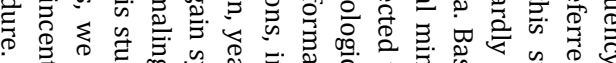

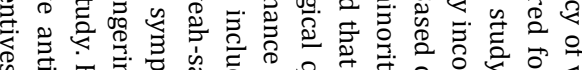
क ज.

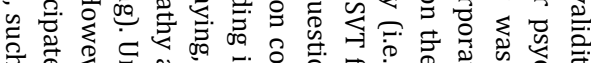

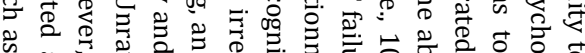

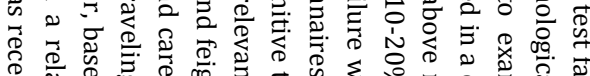

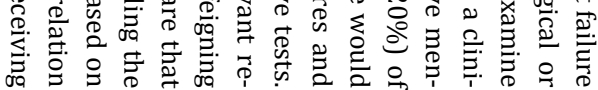

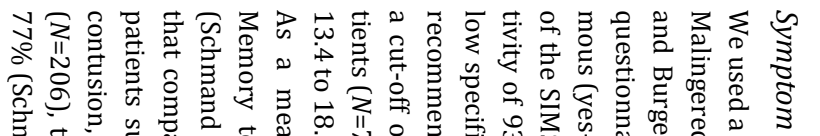

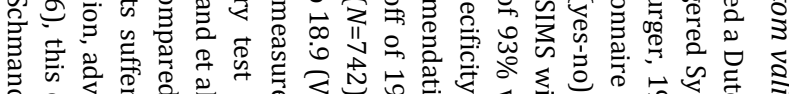

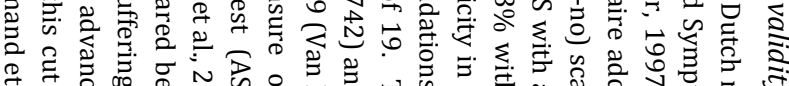

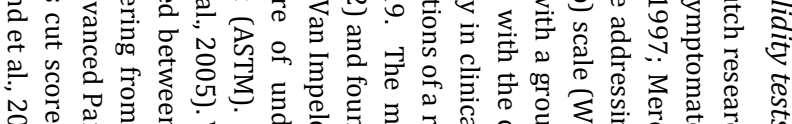

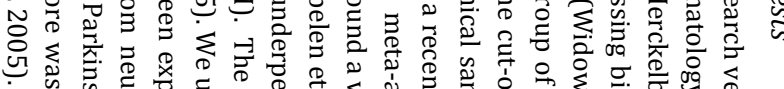

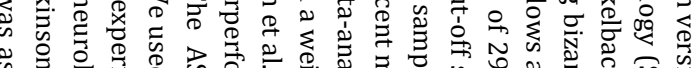

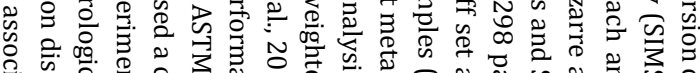

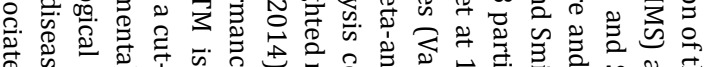

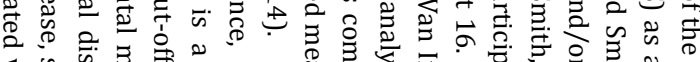

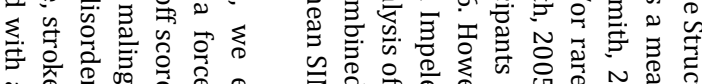

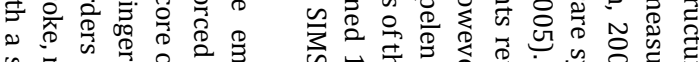

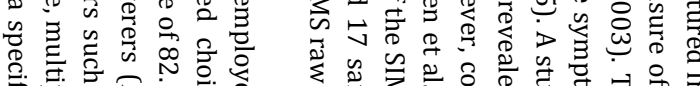

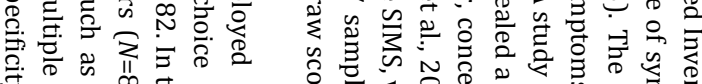

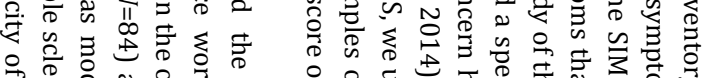

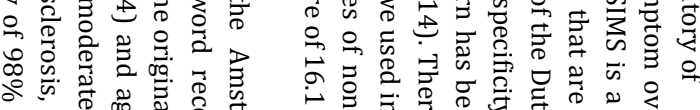

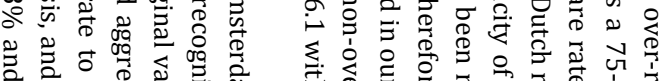
य 出

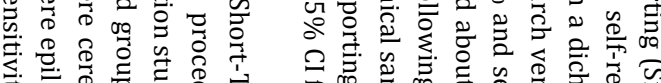

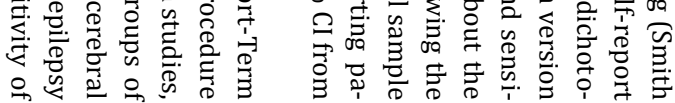

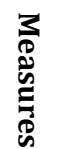

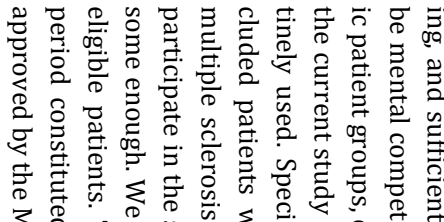
उ冬

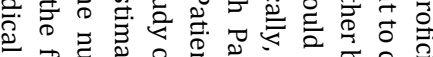

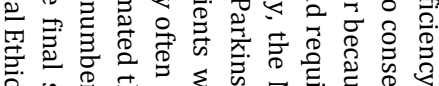

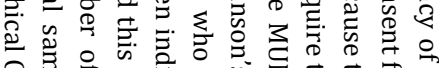

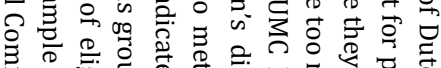

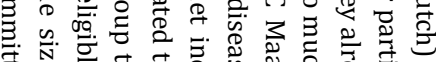
त्ञ

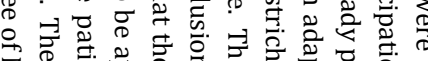
उ

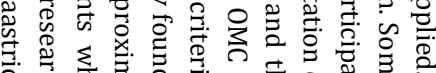

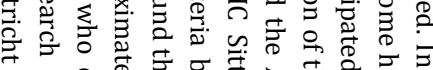

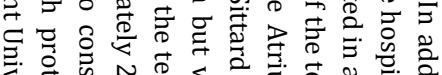

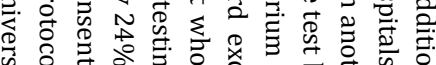

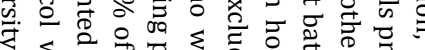

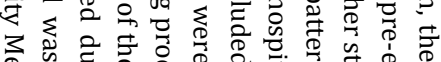
के

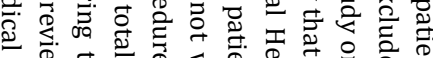

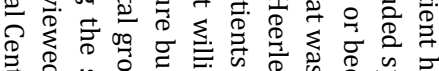

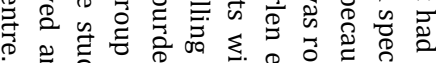

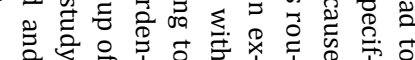




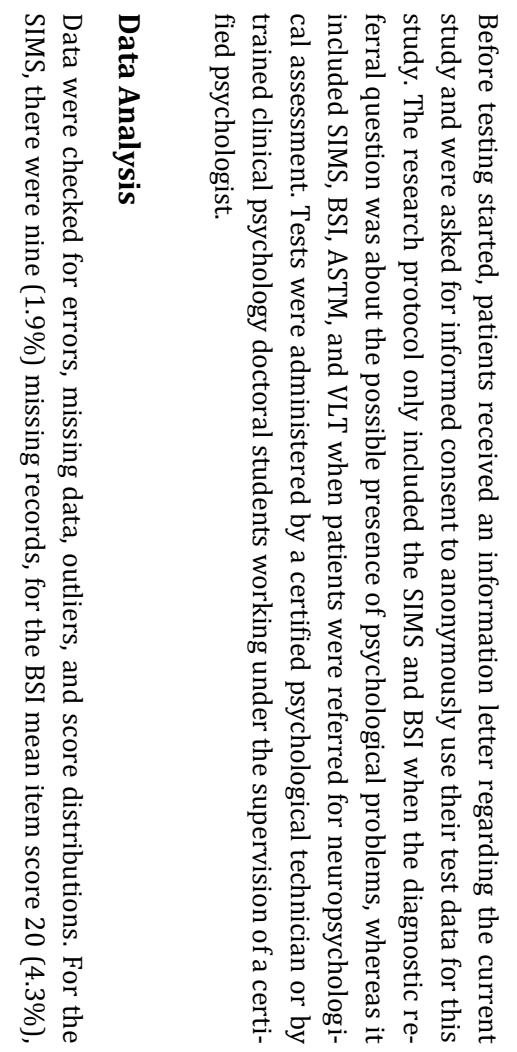

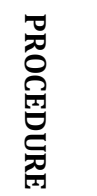

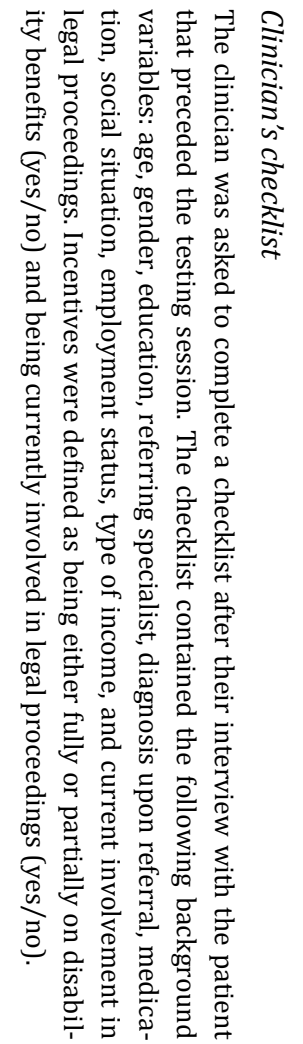

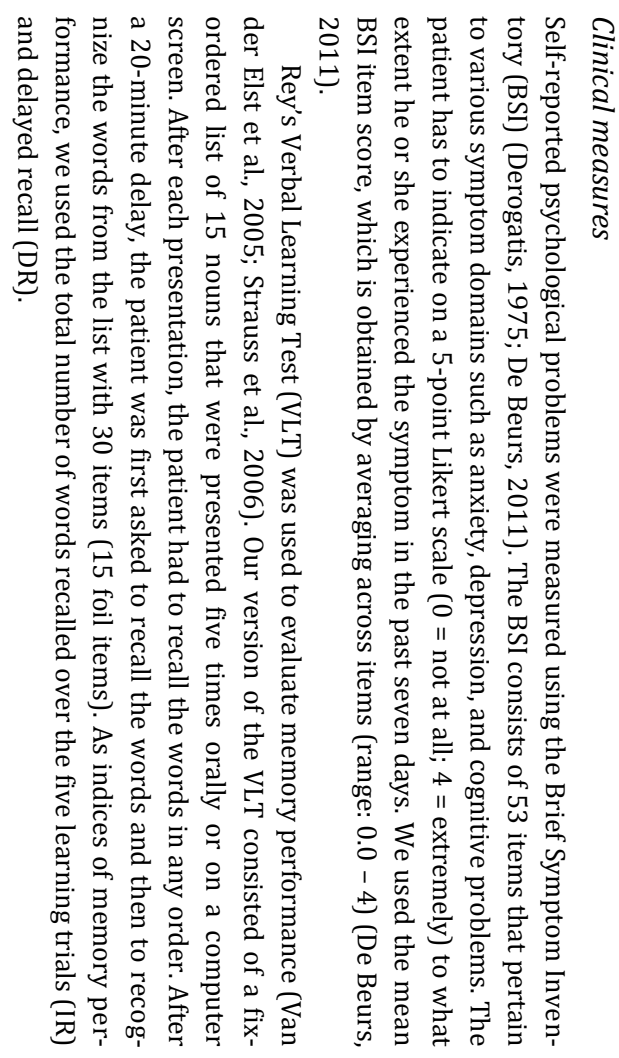

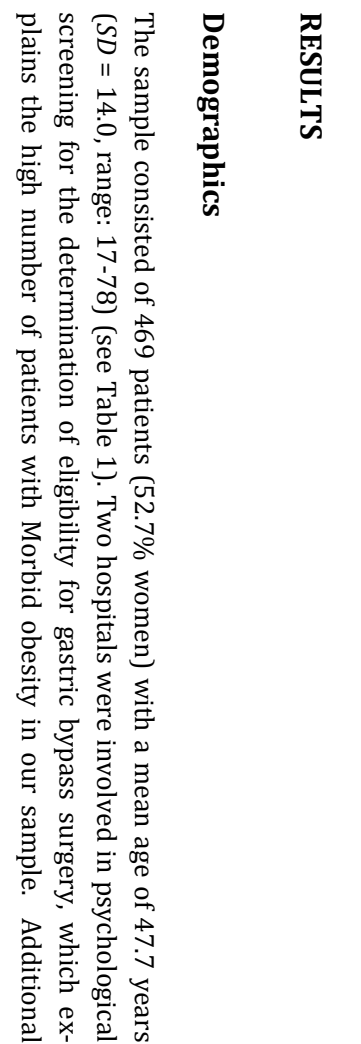

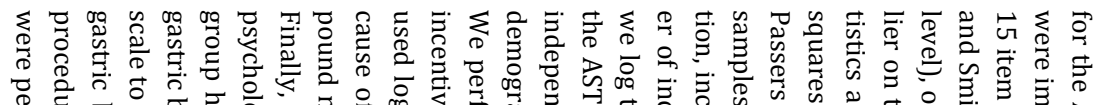

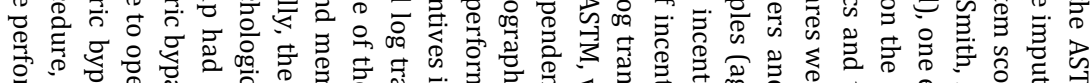

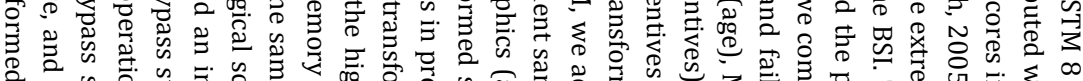

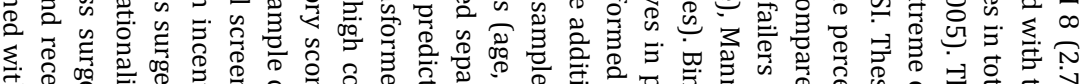

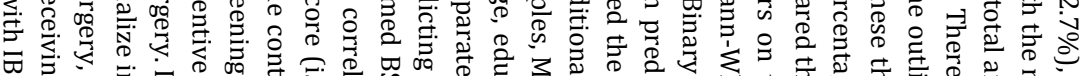

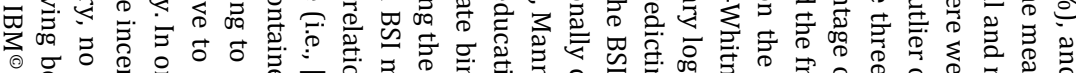

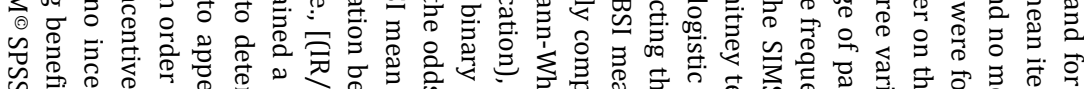

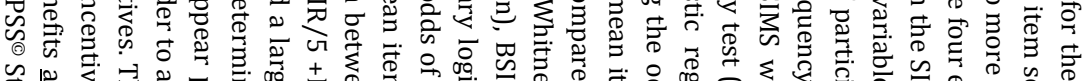

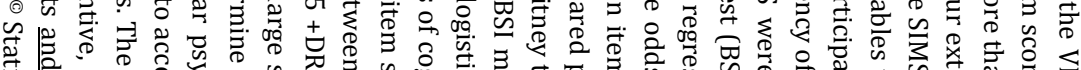
苟.

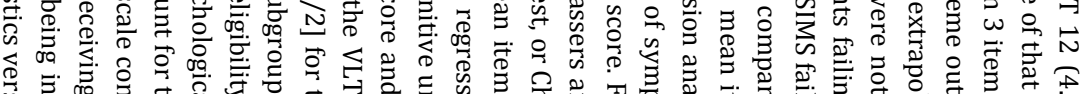

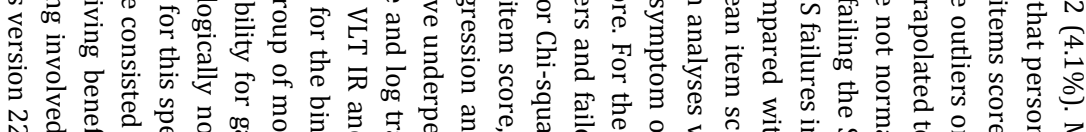

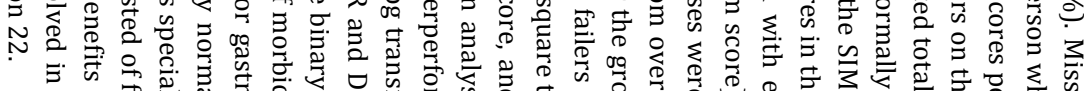

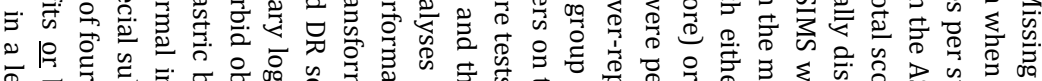

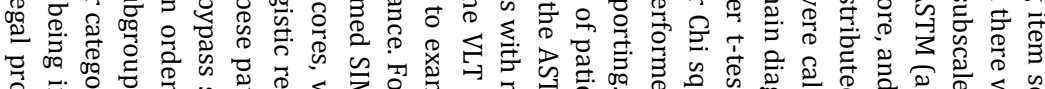

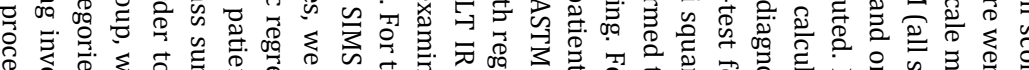

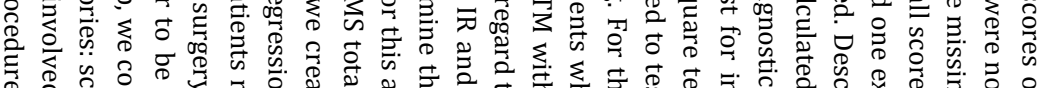

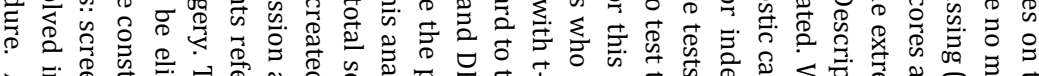

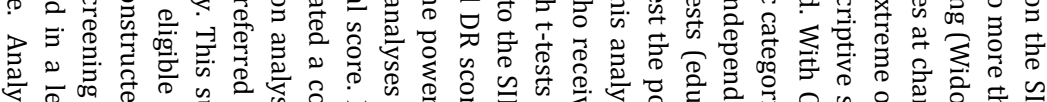

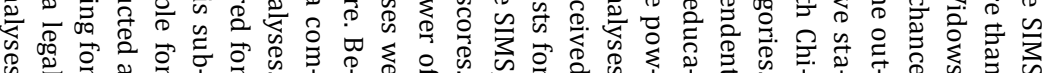




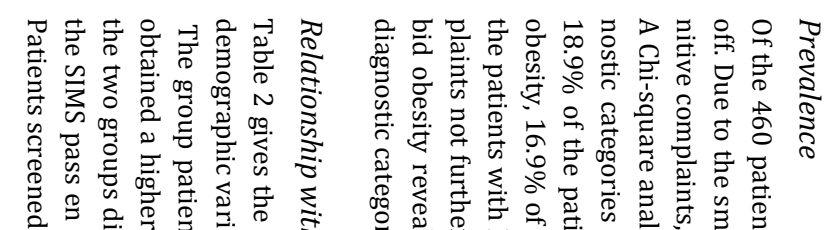

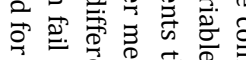

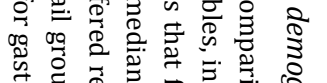

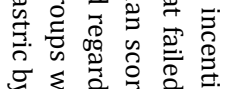

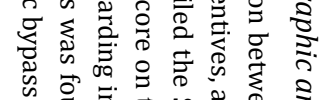
के

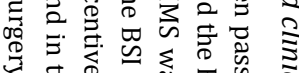

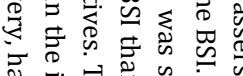

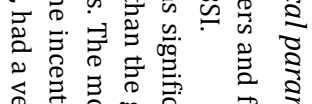

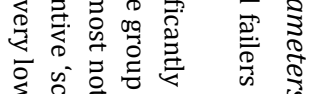

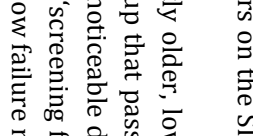

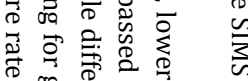

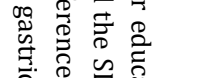

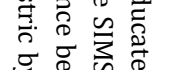

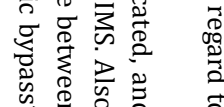

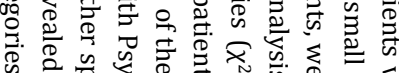

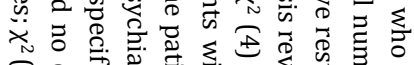

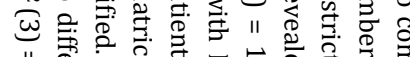

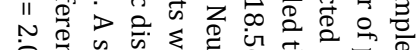

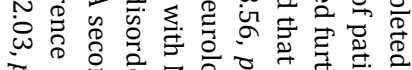
ن

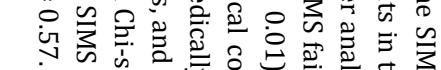

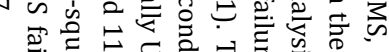

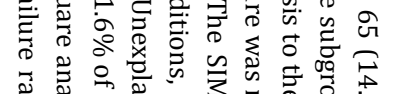

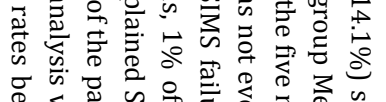

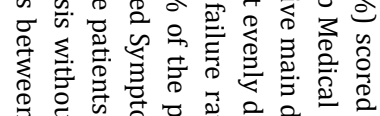

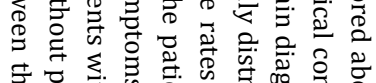

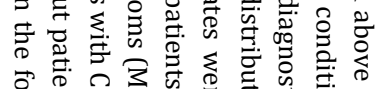

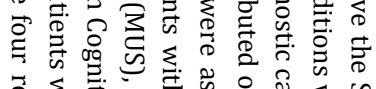

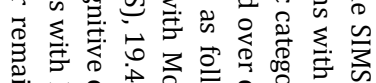

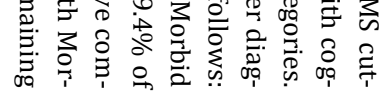




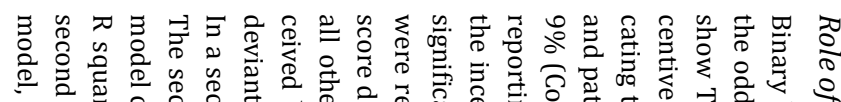

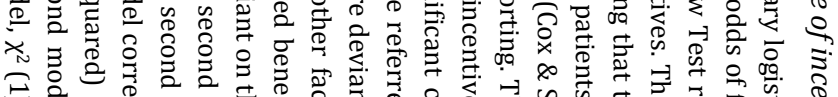

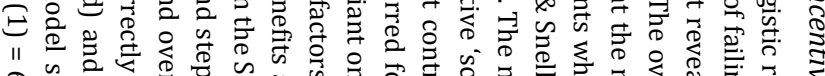

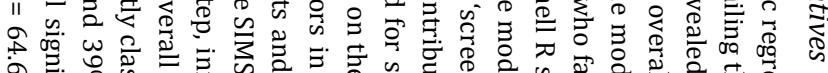

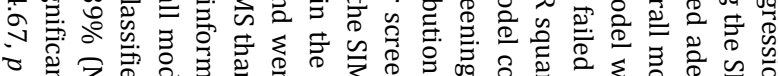

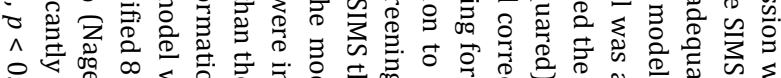

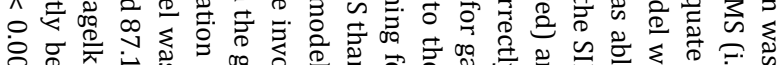

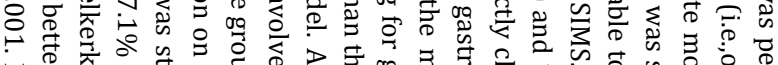

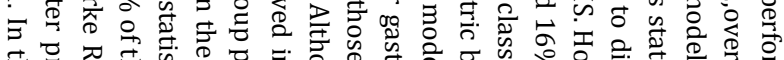

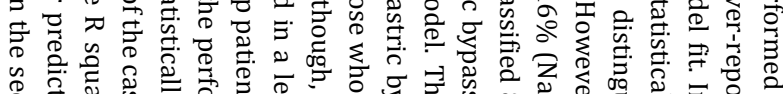

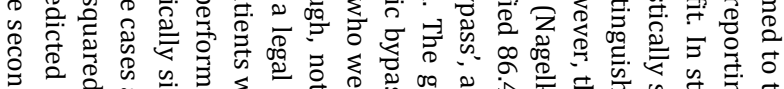

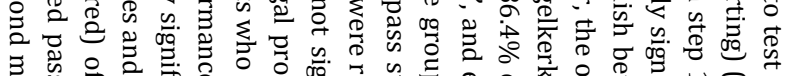

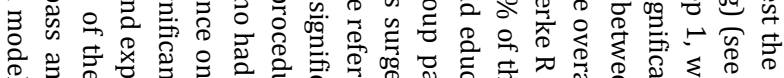

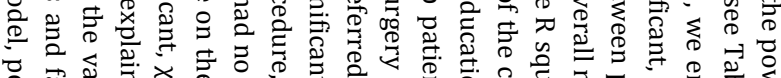

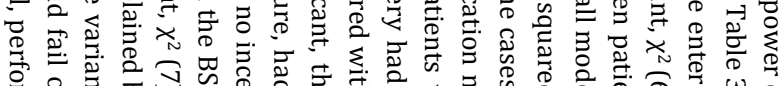

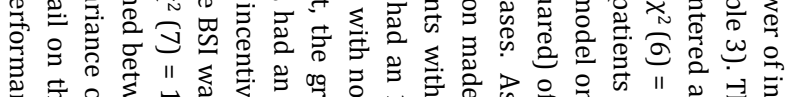

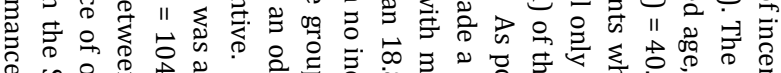

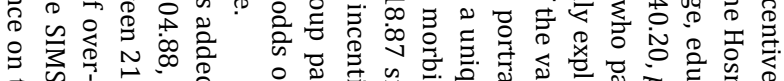

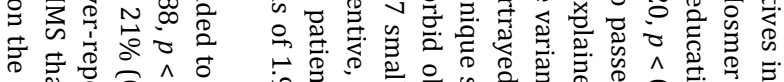

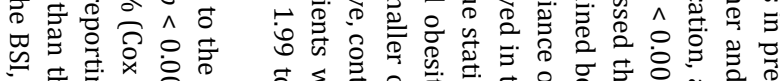

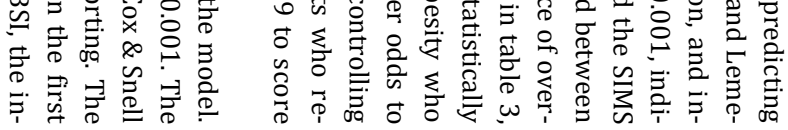
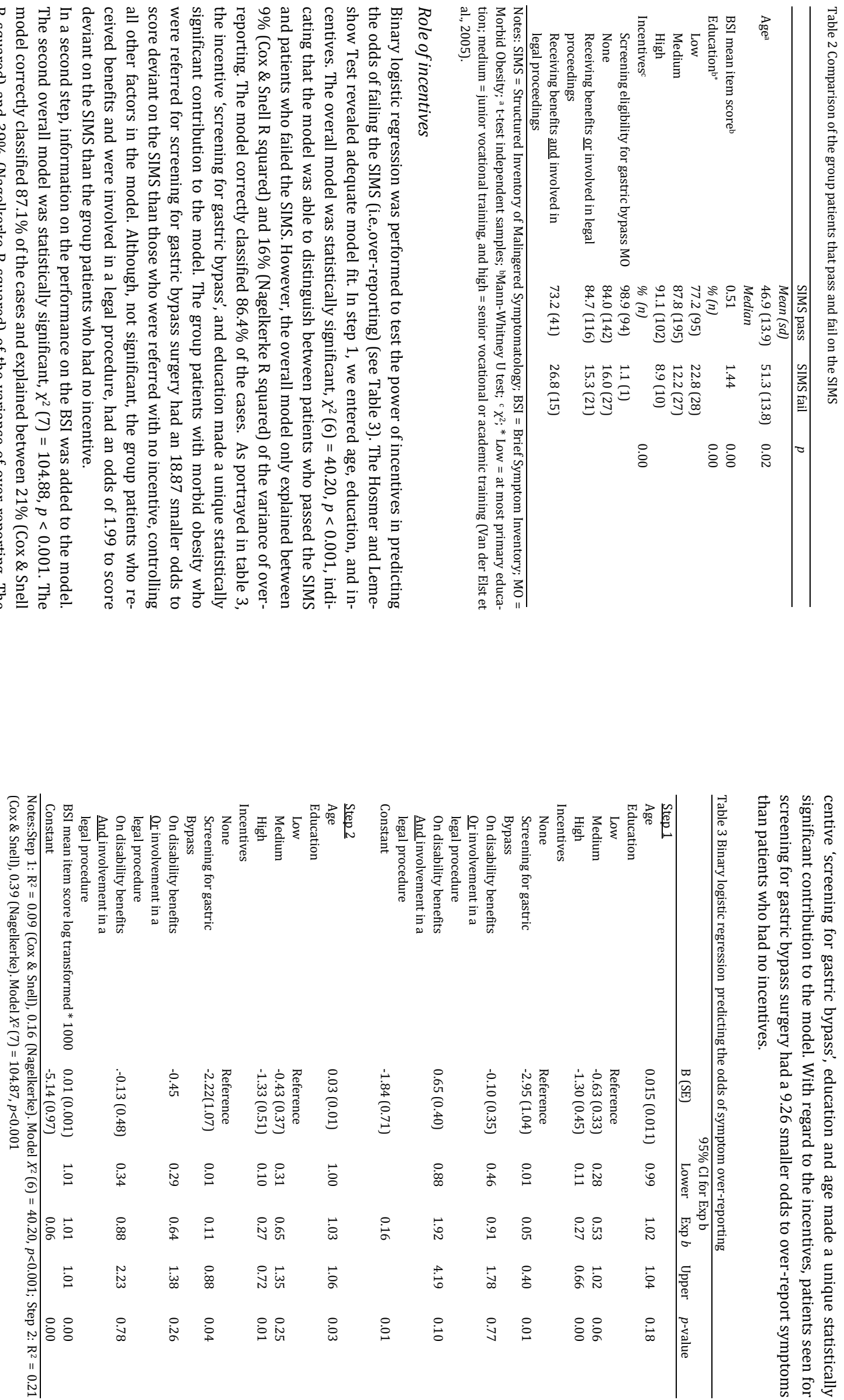


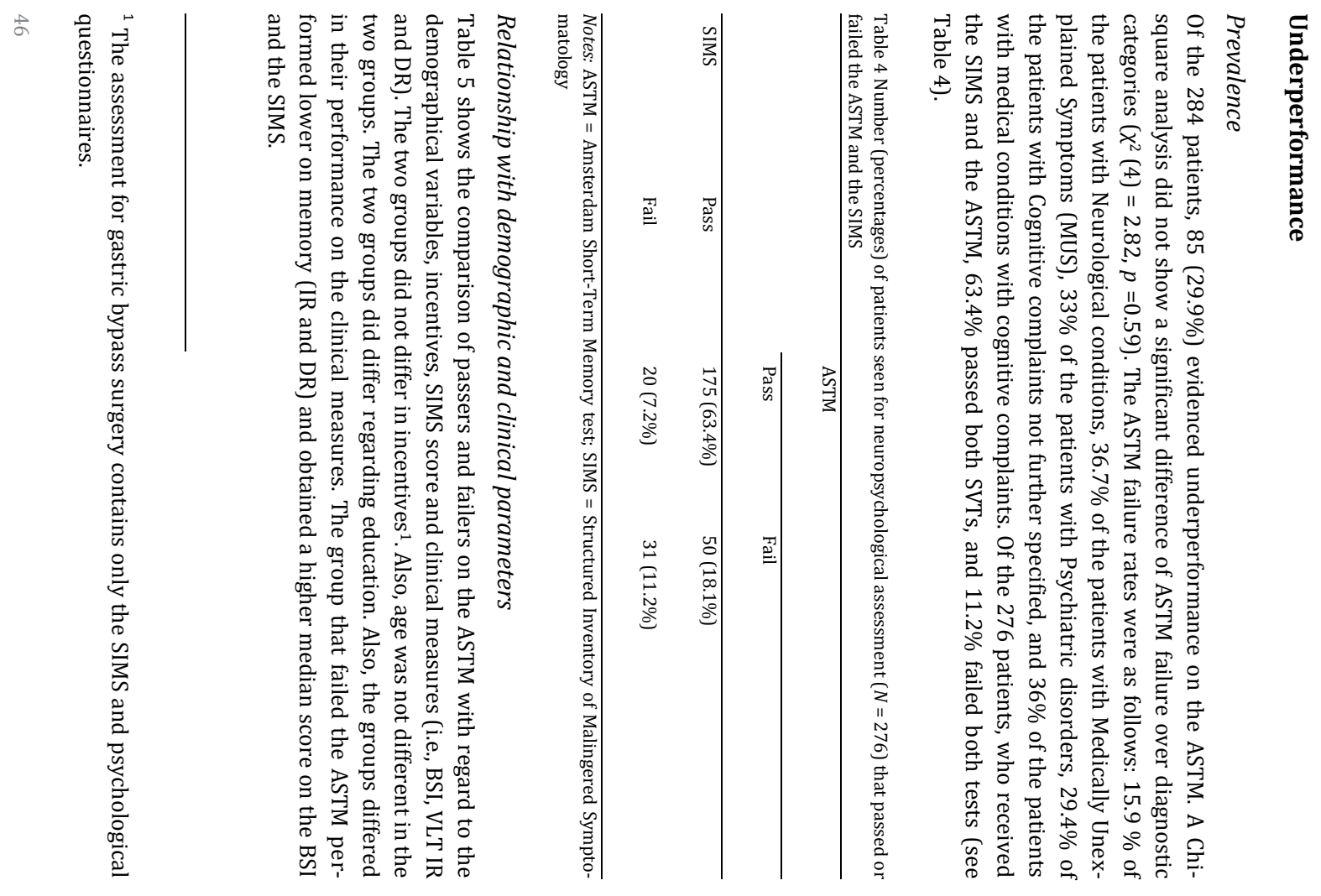

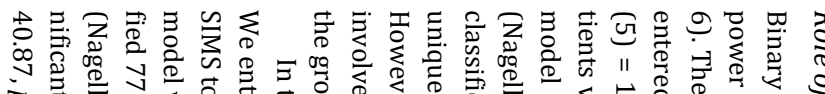

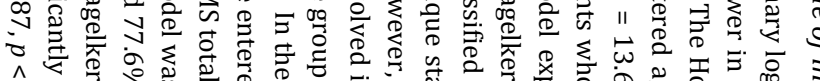

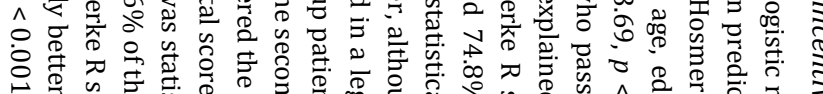

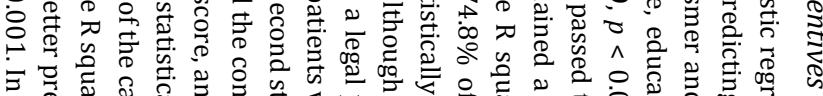

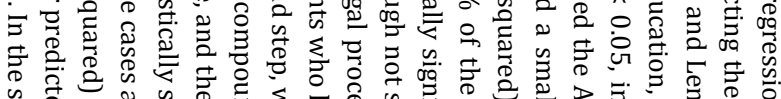

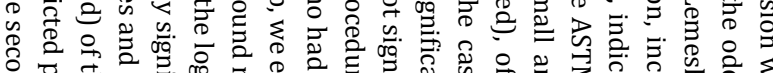

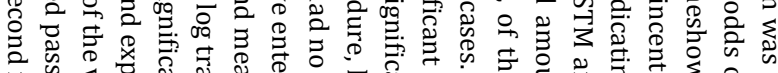

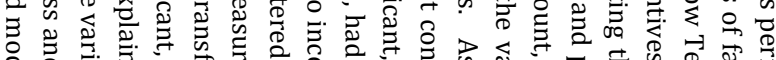

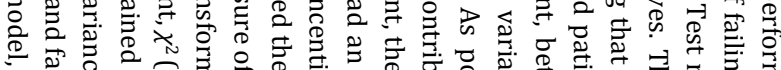

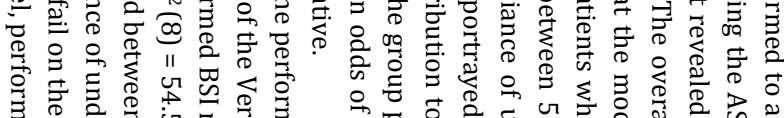

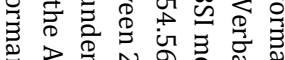

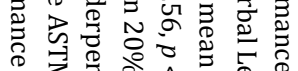

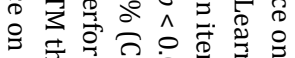

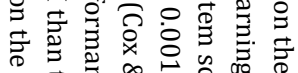

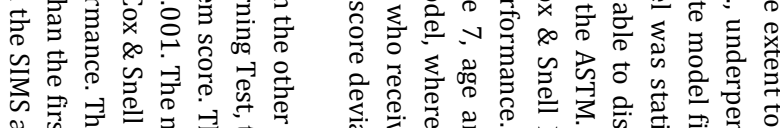

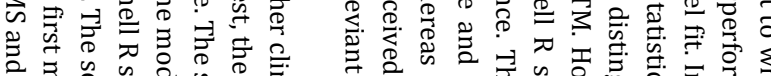

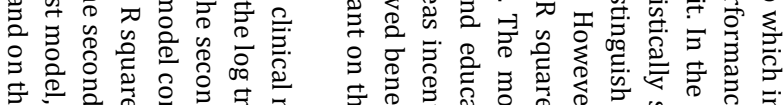

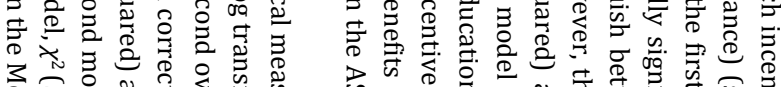

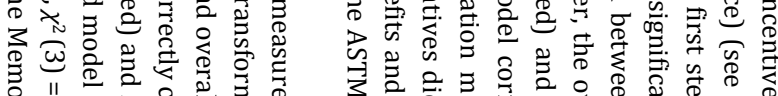

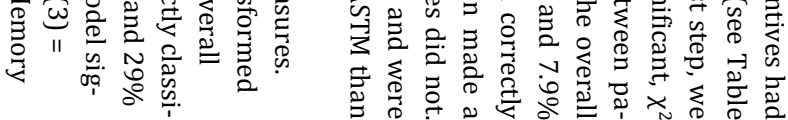

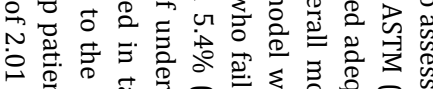

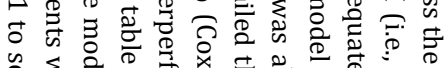

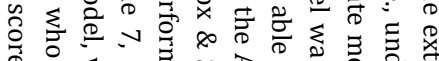

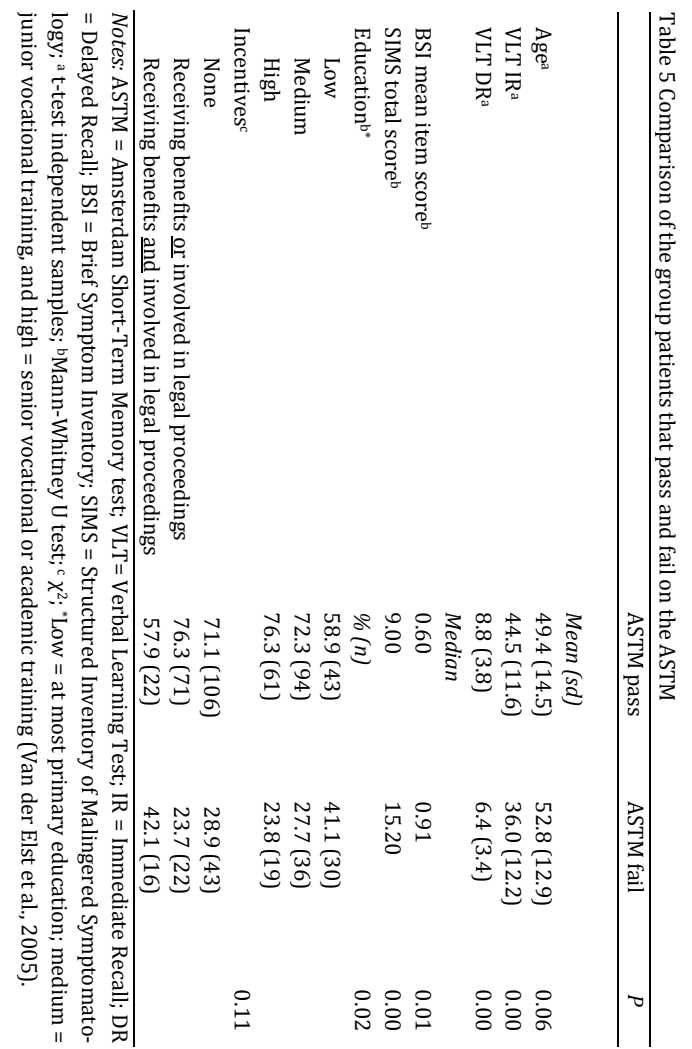




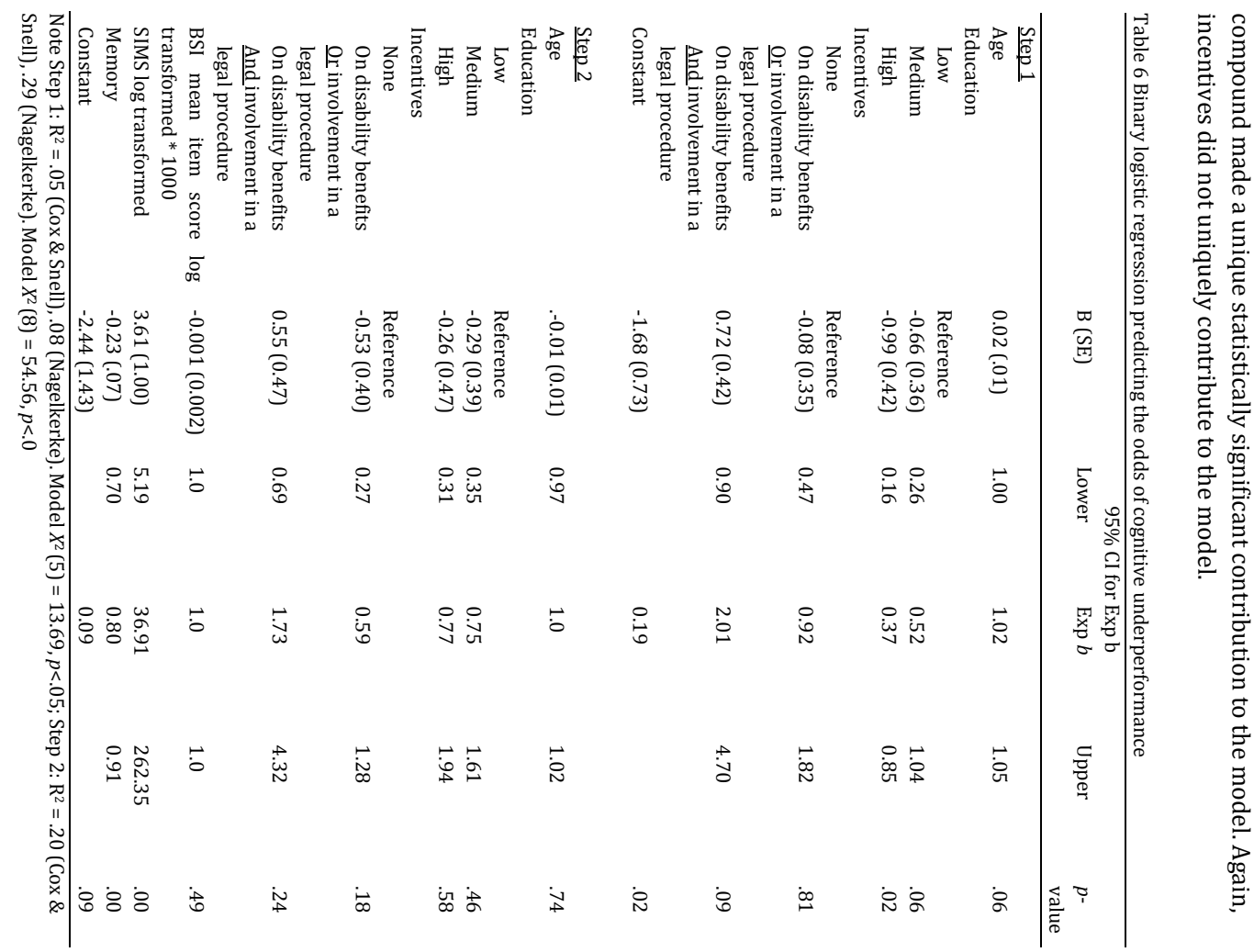

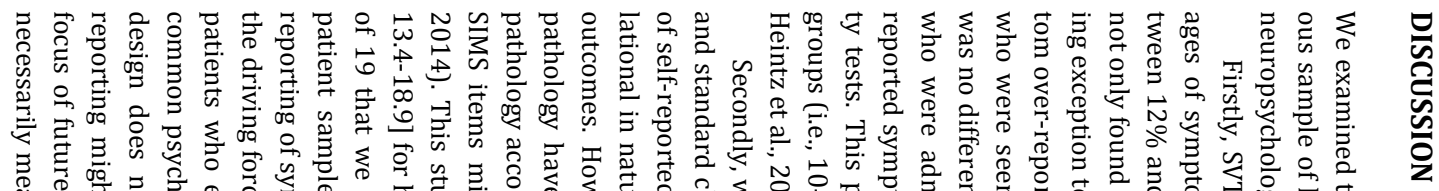

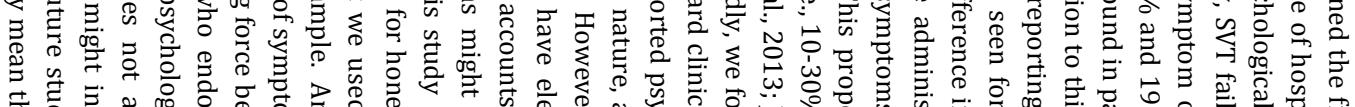

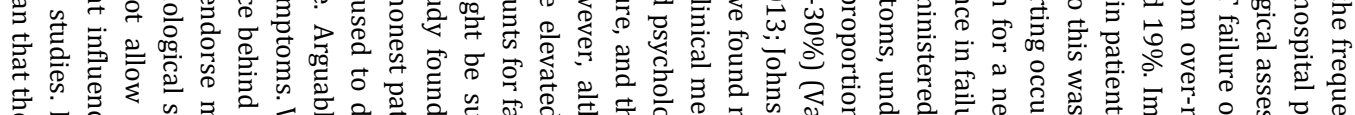

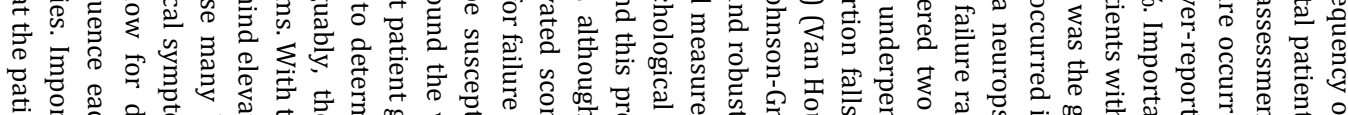

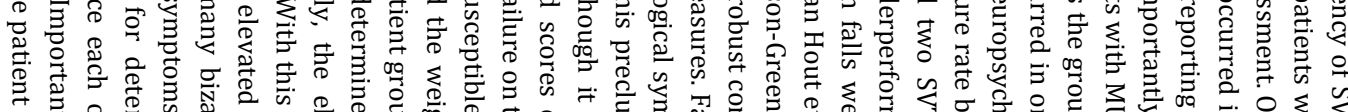

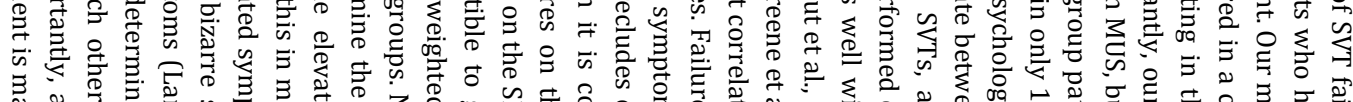

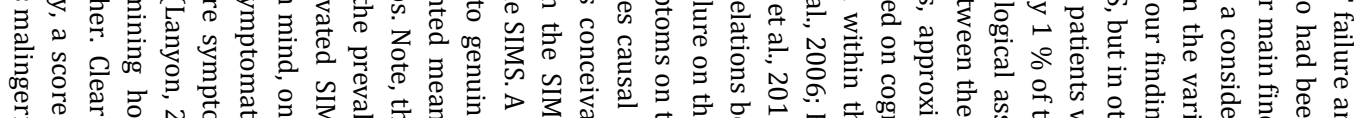

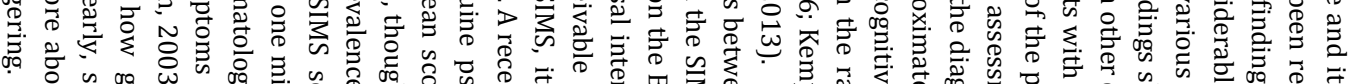

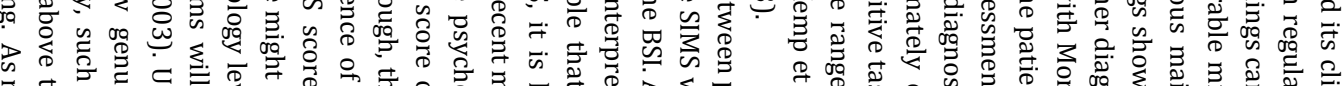

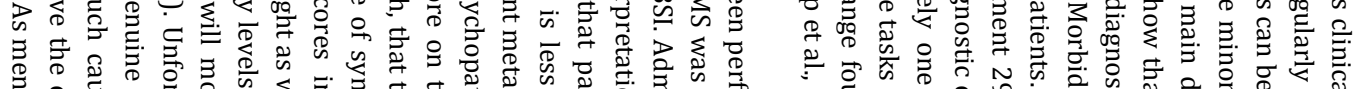

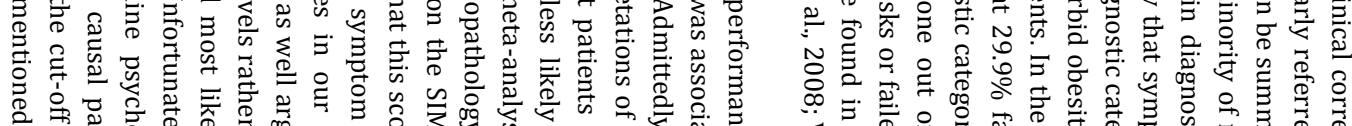

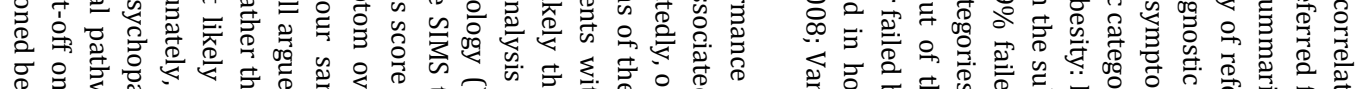

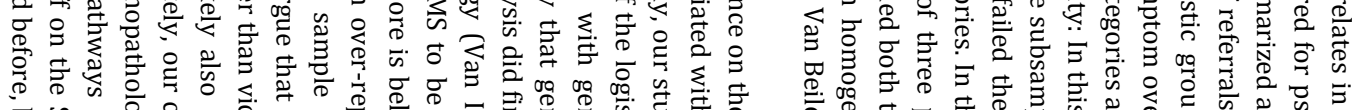

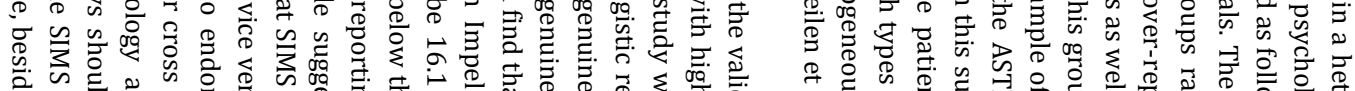

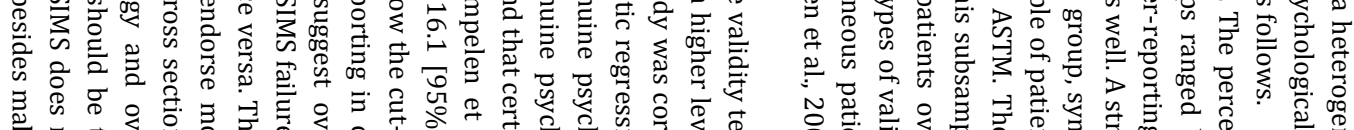

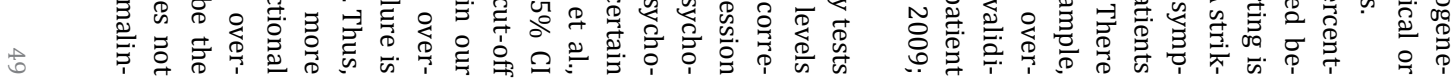




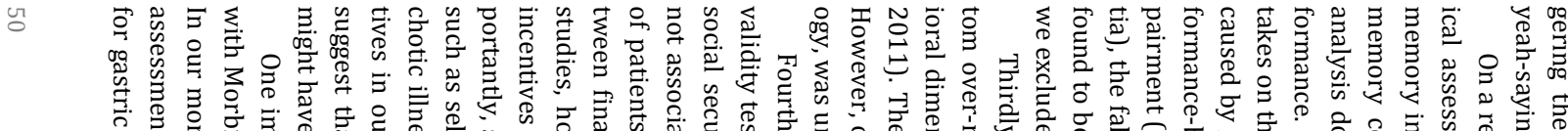

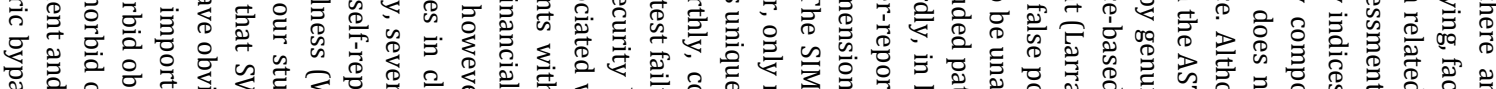

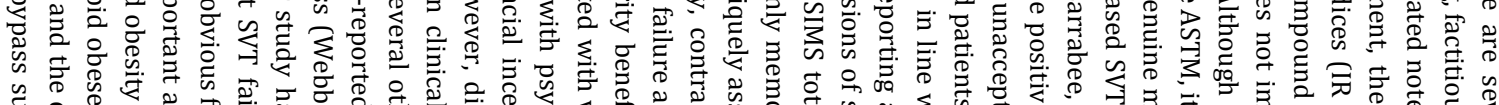

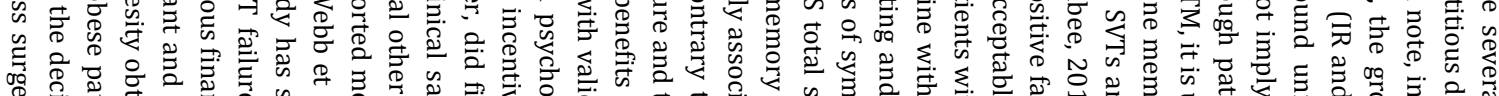

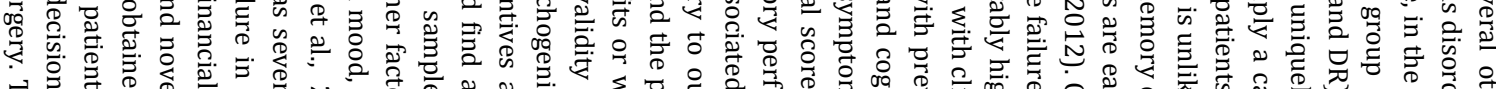

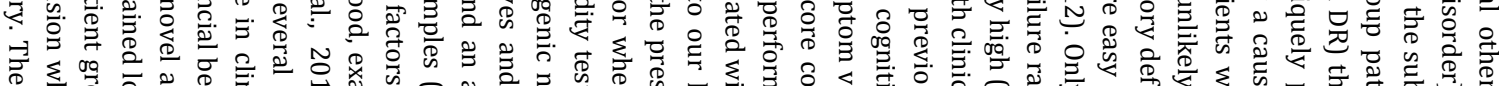

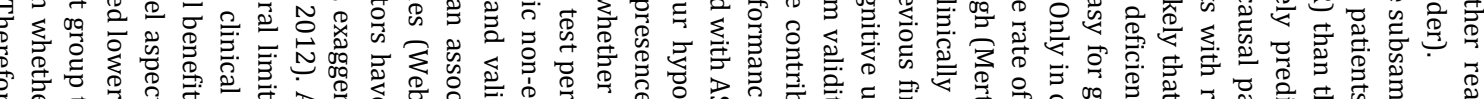

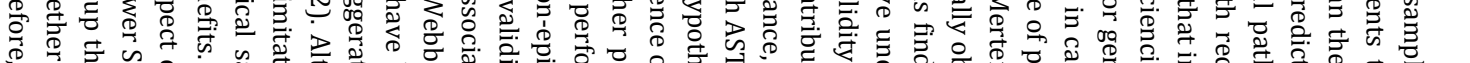

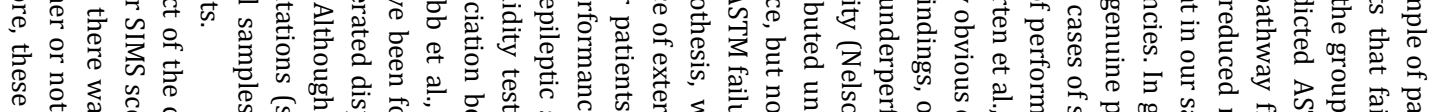

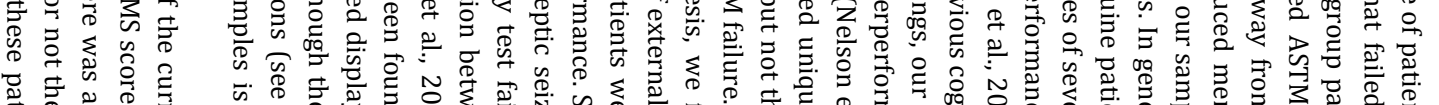

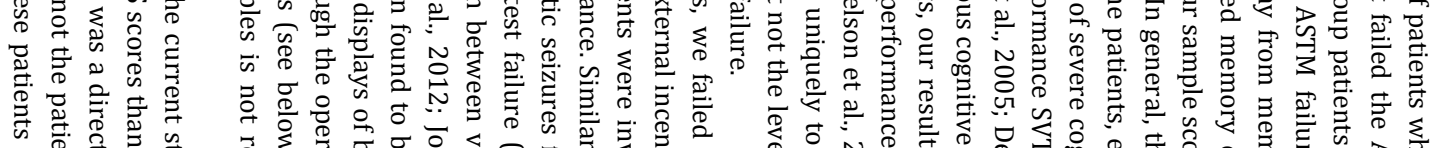

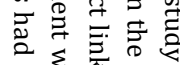

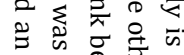

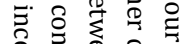

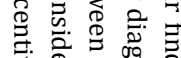

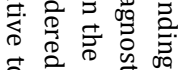

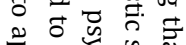

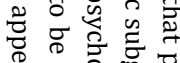
要

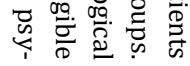

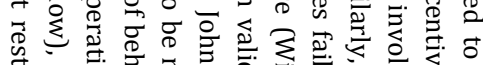

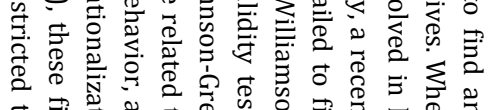

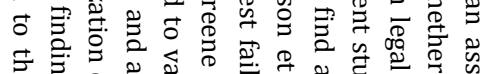

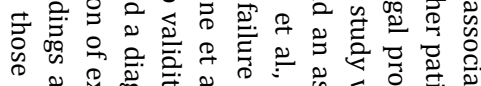

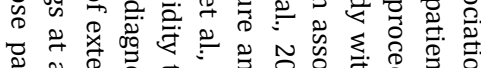

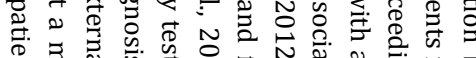

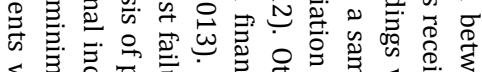

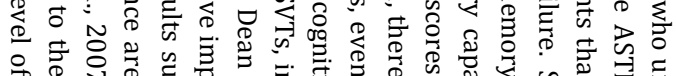

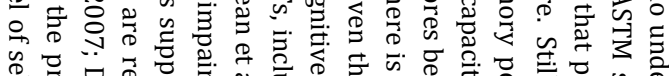

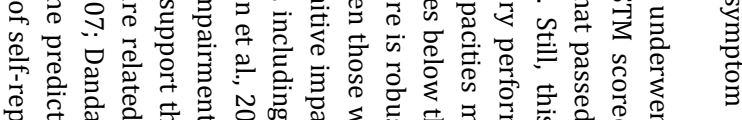

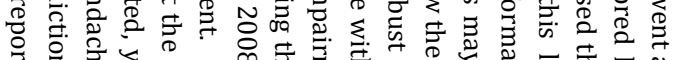

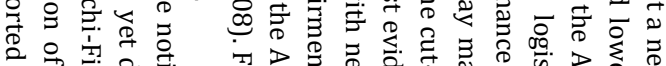

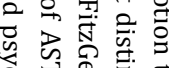

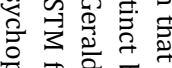

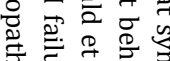

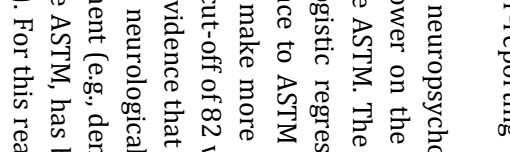

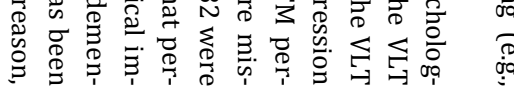

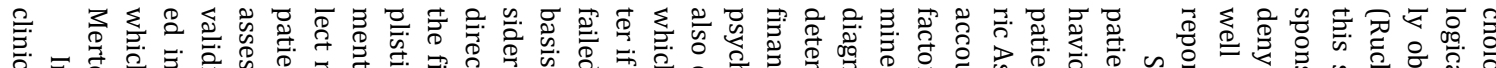

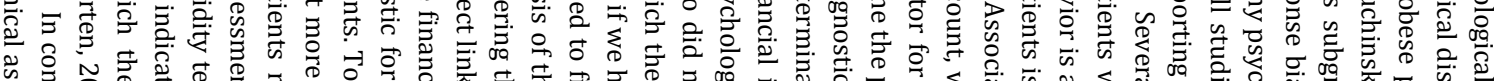

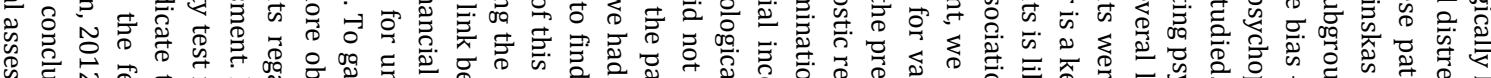

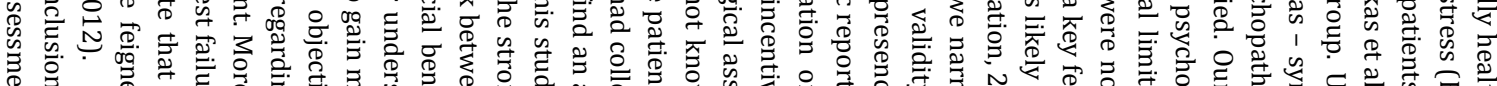

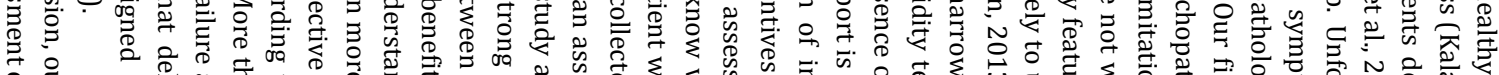

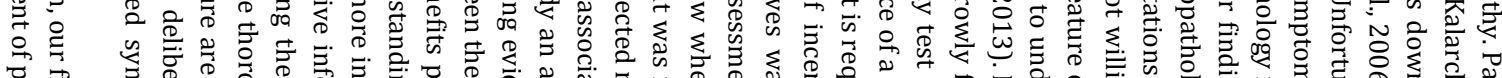

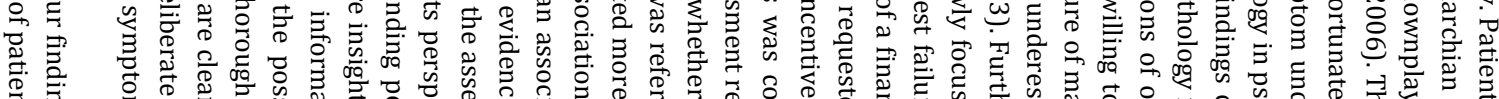

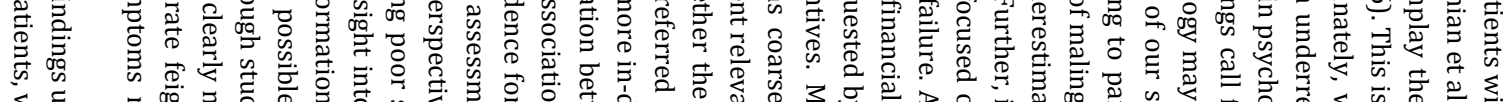

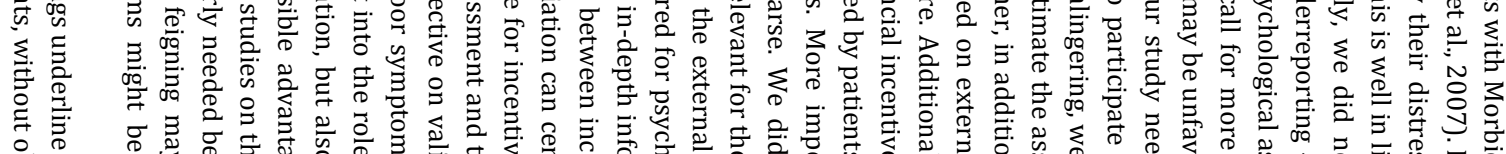

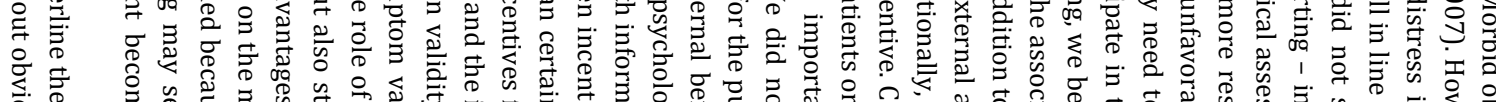

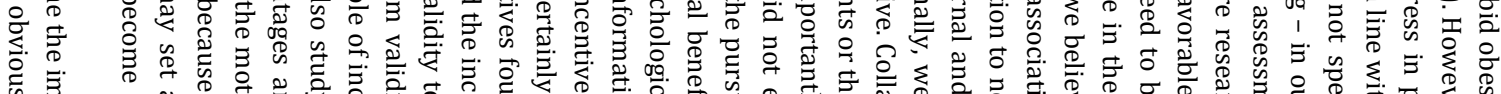

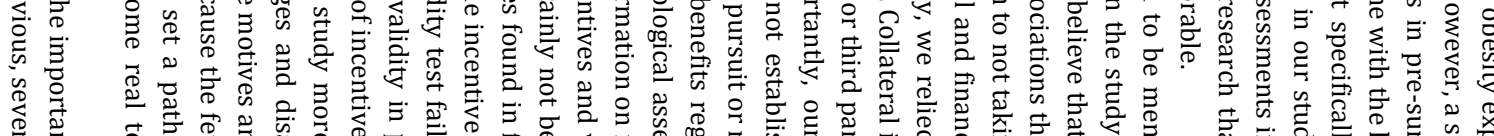

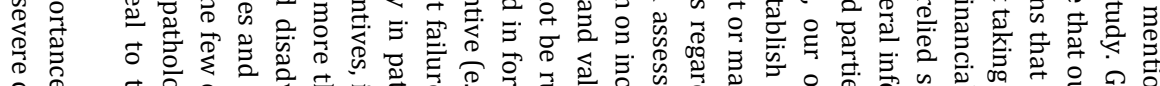

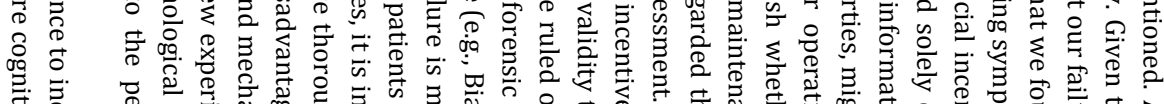

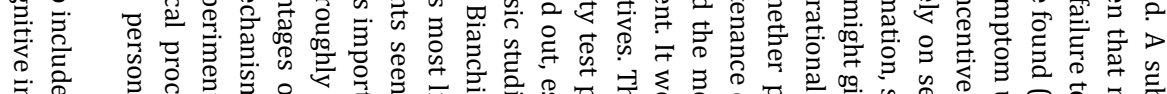

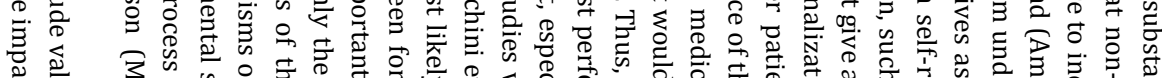

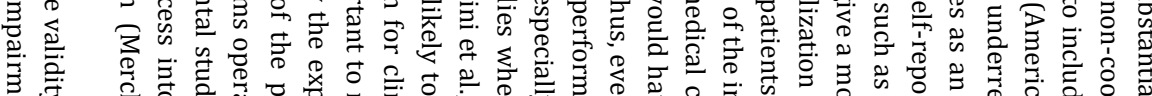

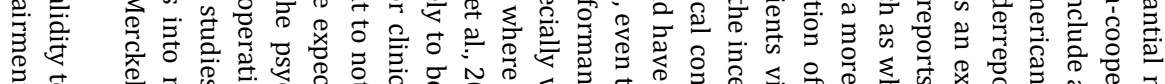

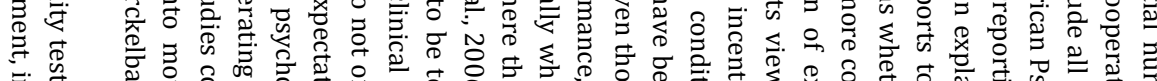

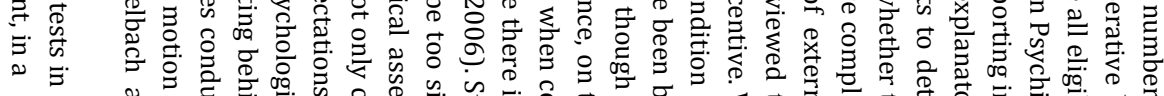

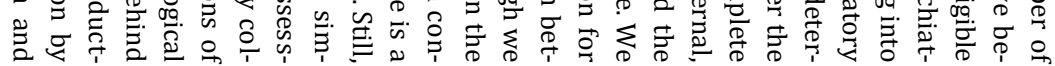

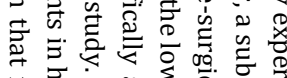

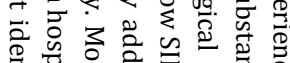

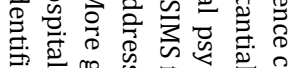

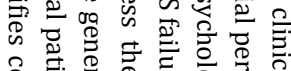

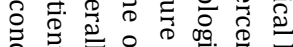

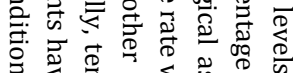

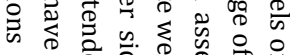
उ.

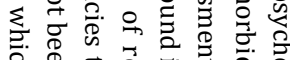


N
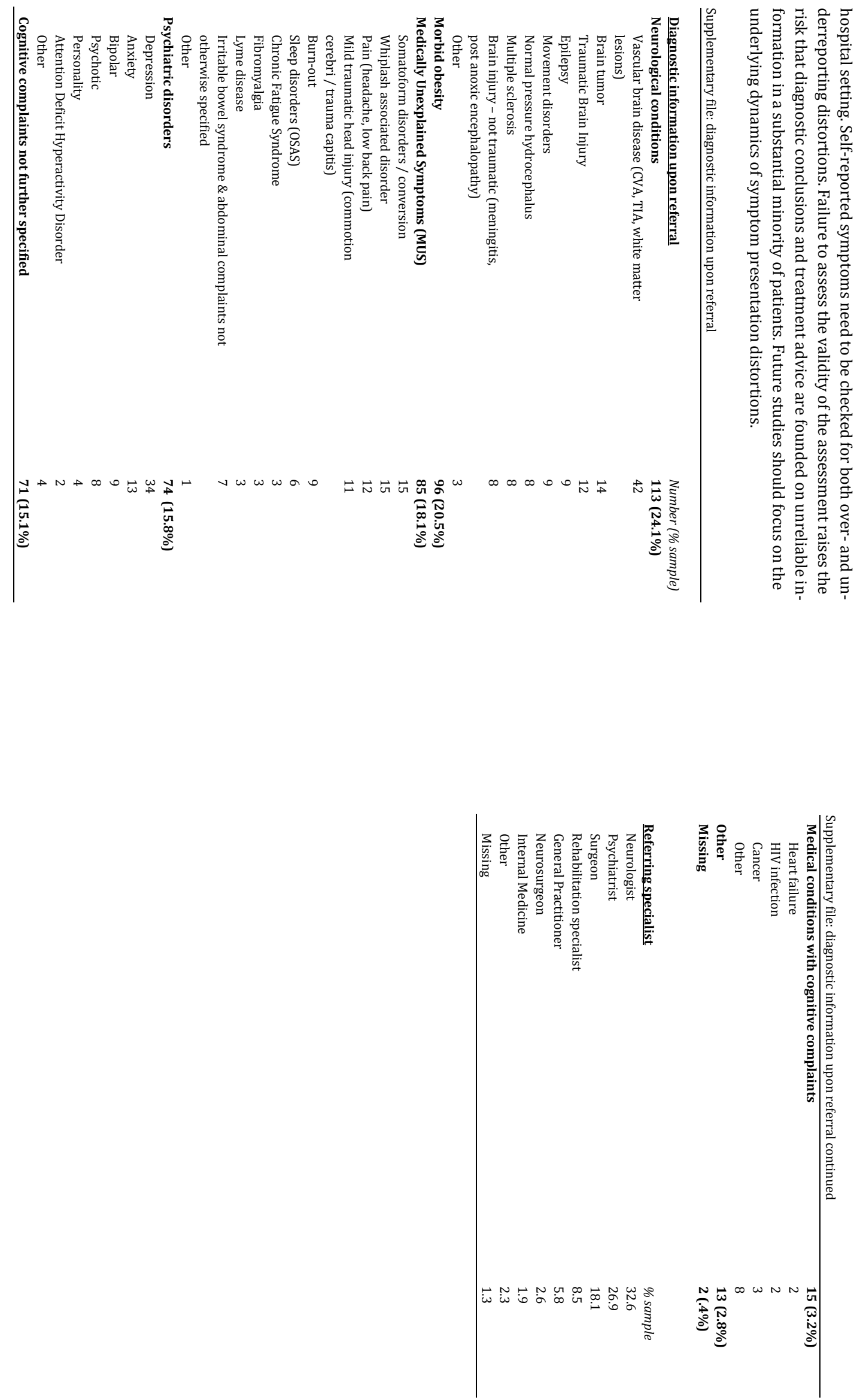

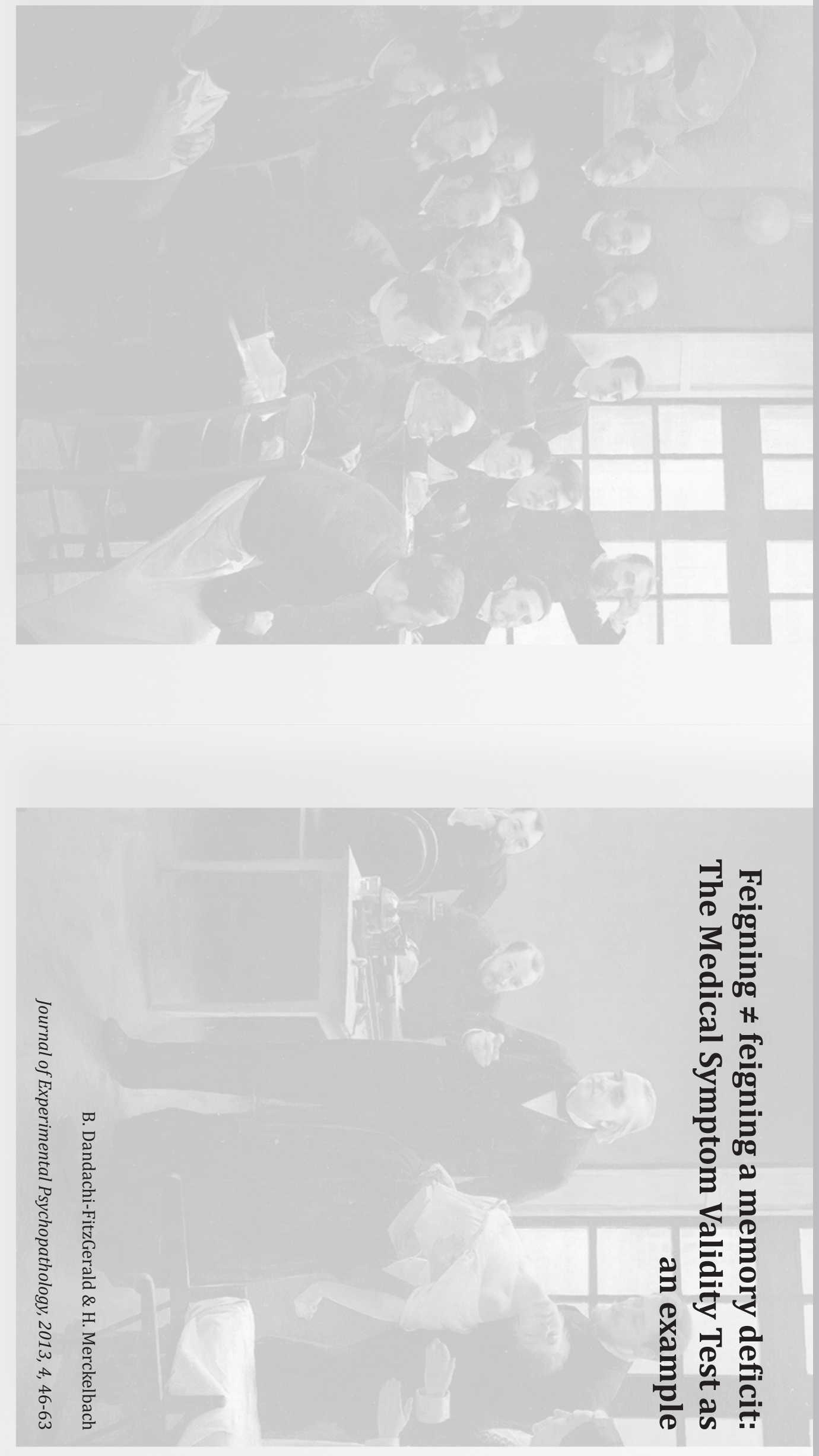

罚 


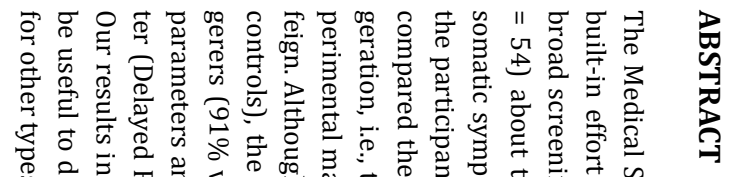

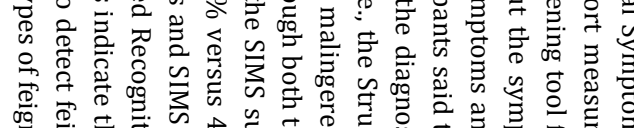

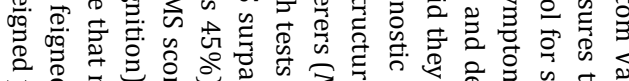

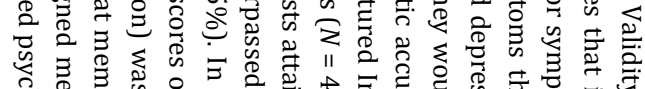

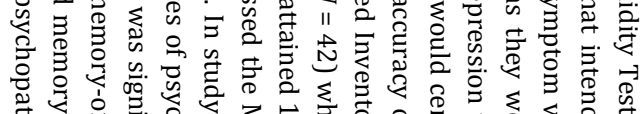

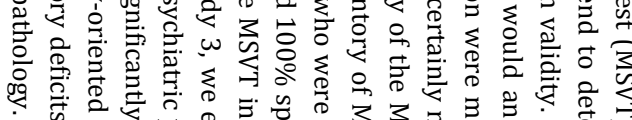

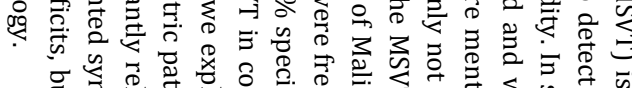

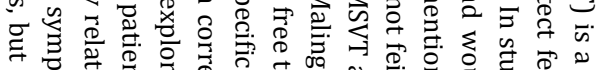

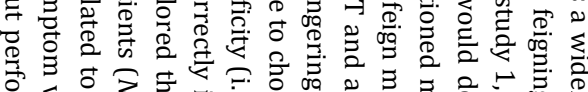

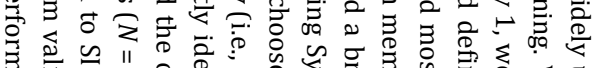

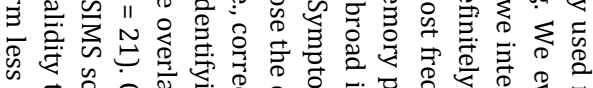

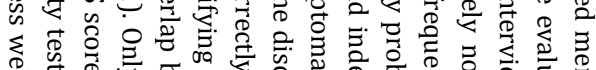

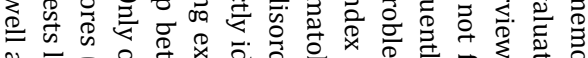
is

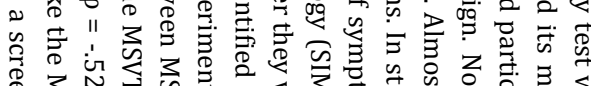

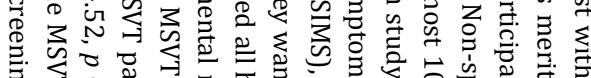

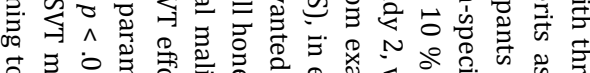

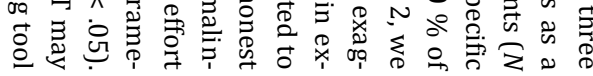

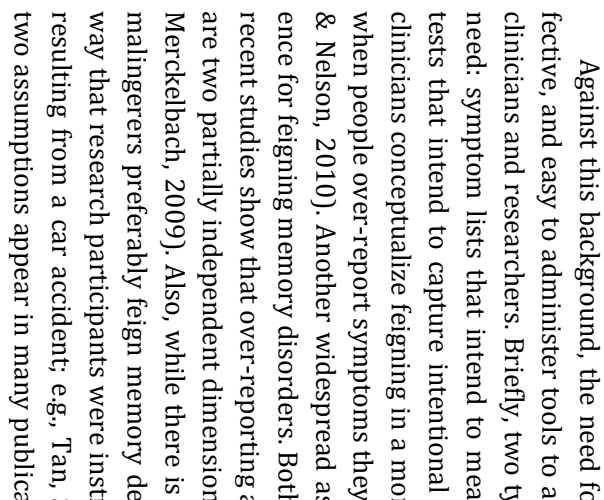

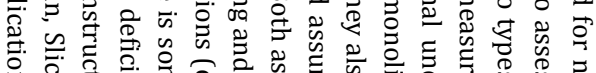

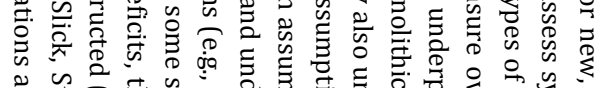

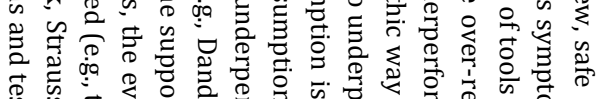

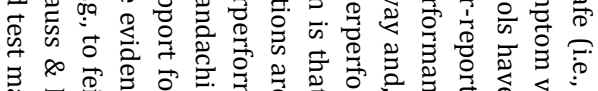

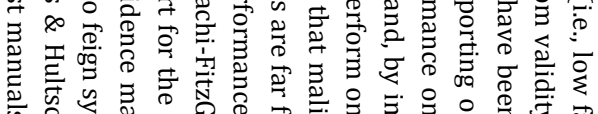

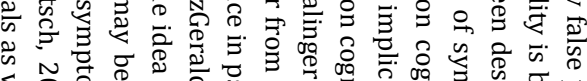

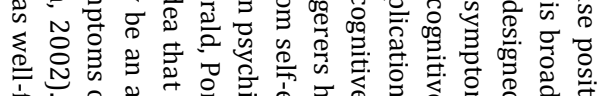

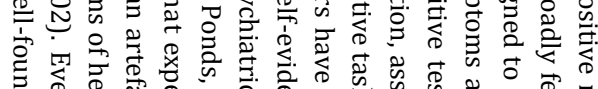

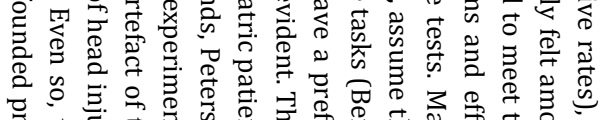

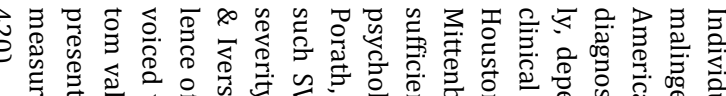

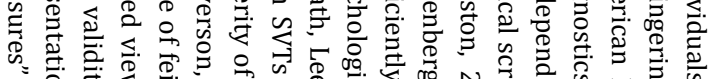

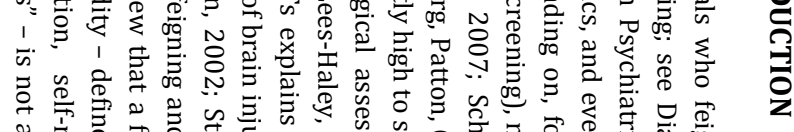

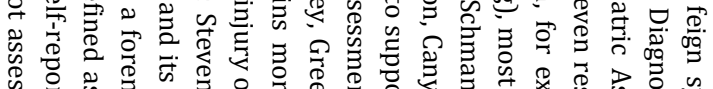

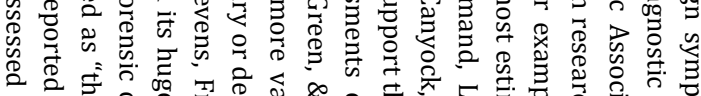

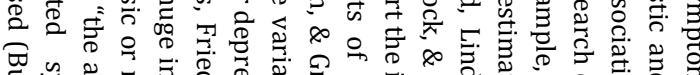

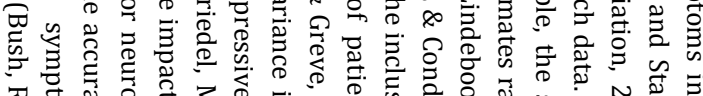

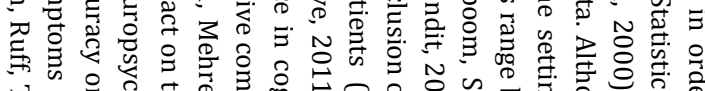

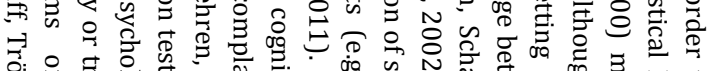

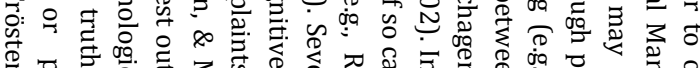

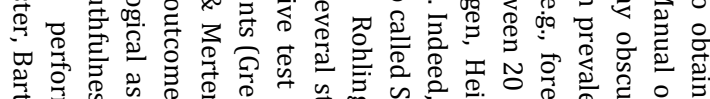

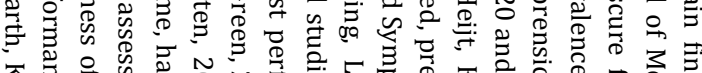

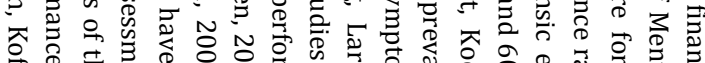

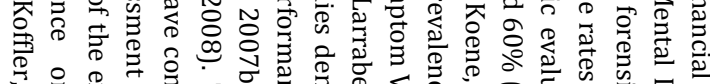

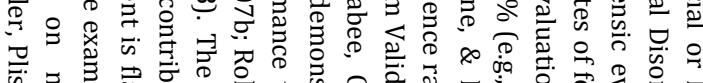

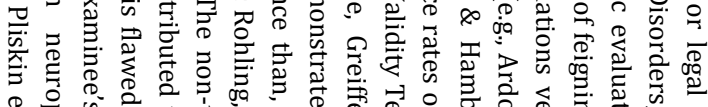

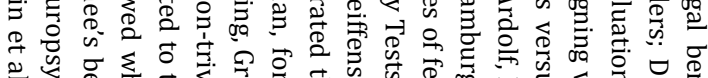

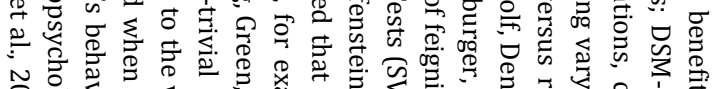

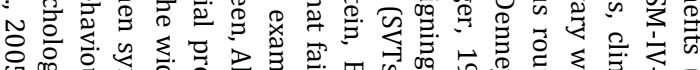

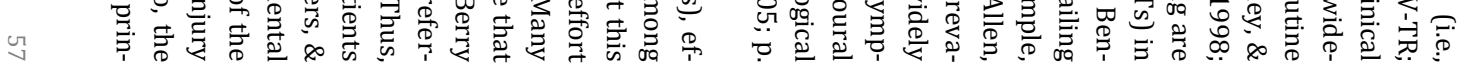




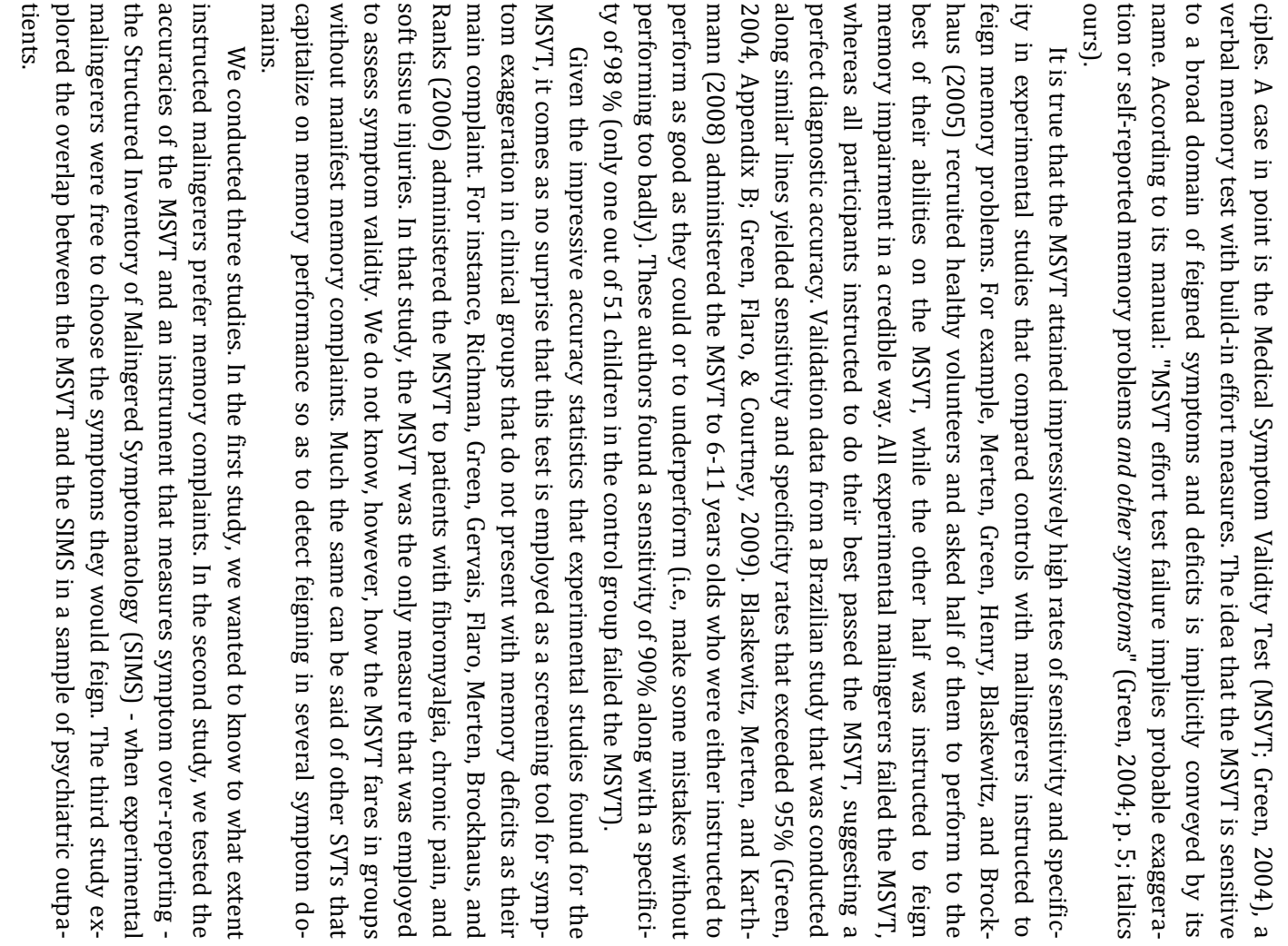

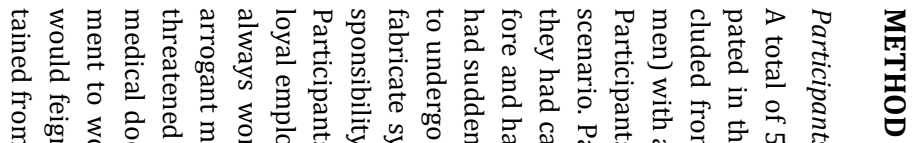

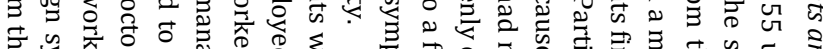

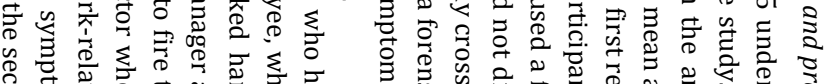

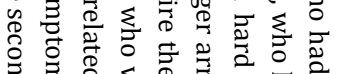

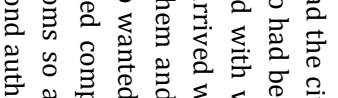
क्ष ठ

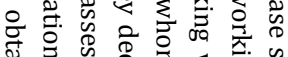

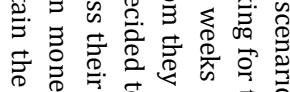

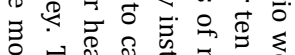

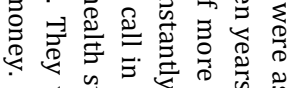

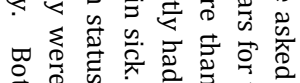

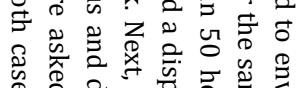

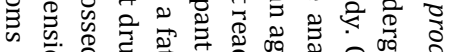

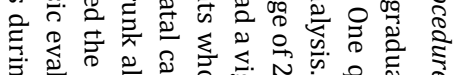

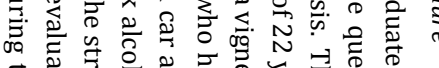

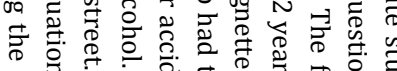

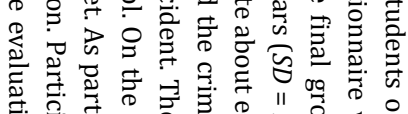

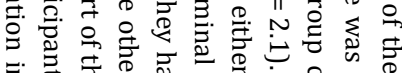

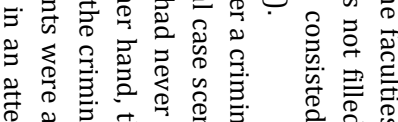

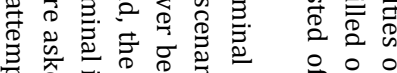

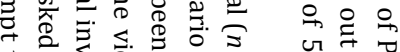
० 0 要

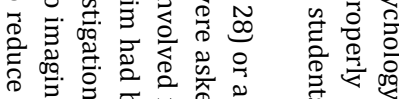

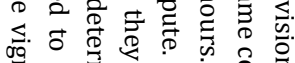
实

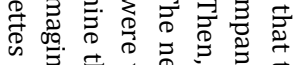

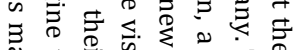

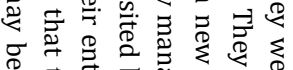

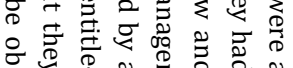

ज。

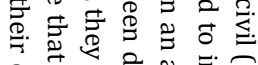

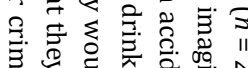

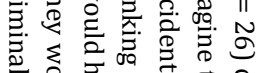

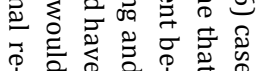

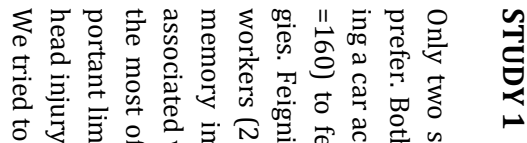

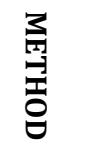

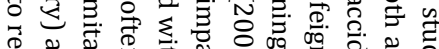

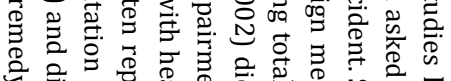

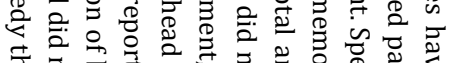

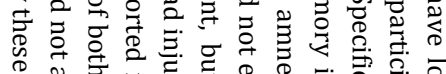

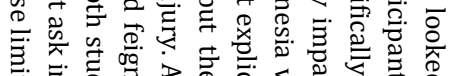

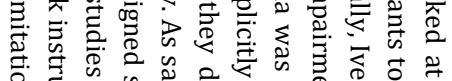

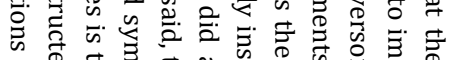

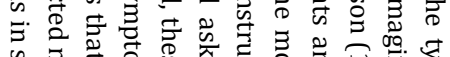

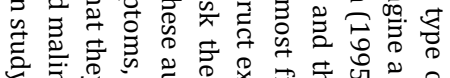

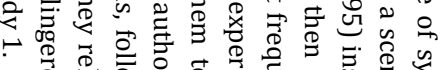

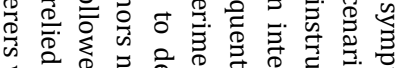

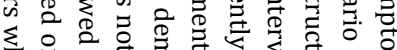

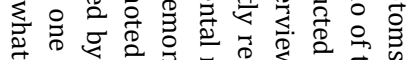

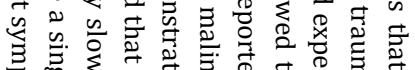

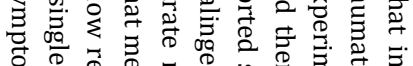

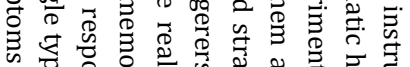

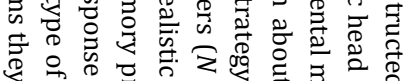

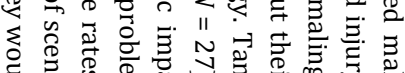

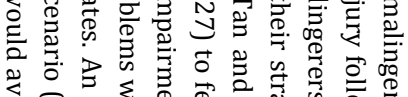

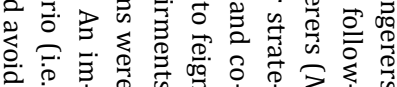




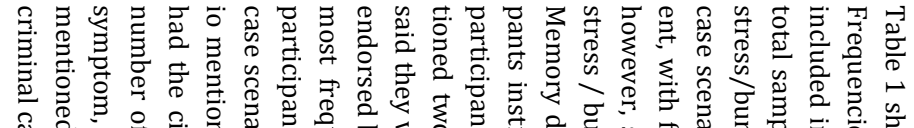

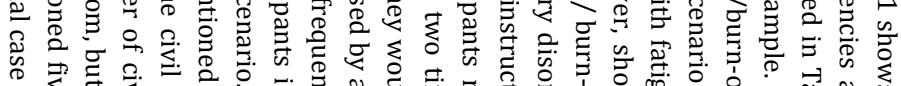

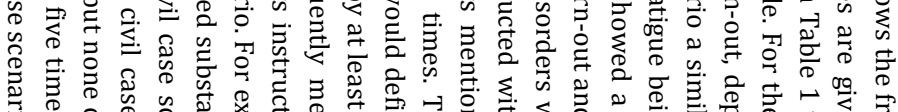
ㄱ.

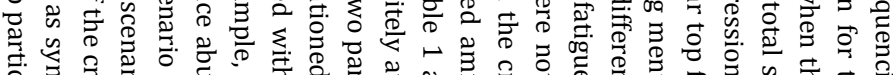

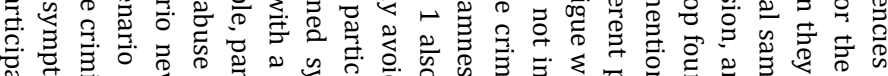

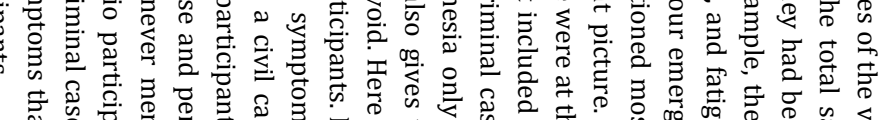

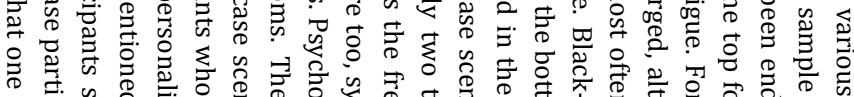
क

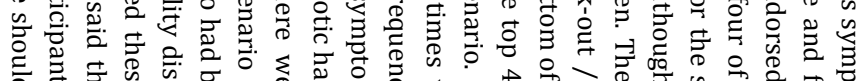

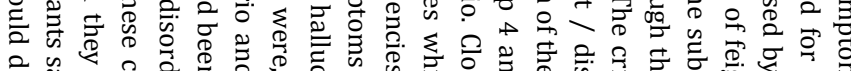

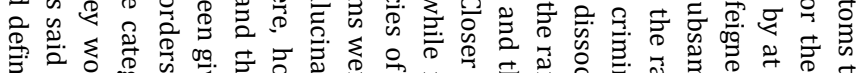

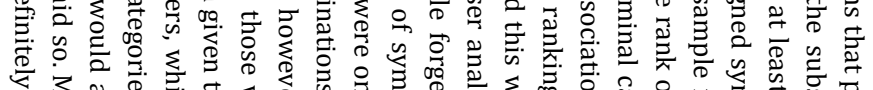

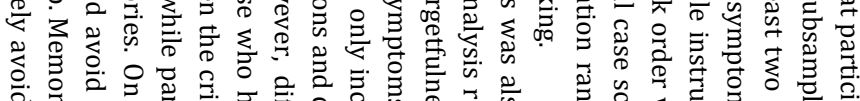

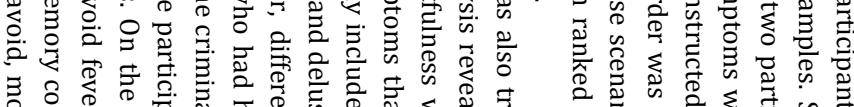

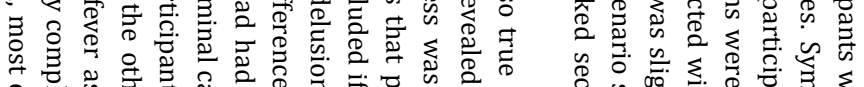

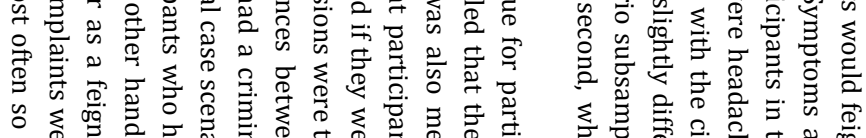

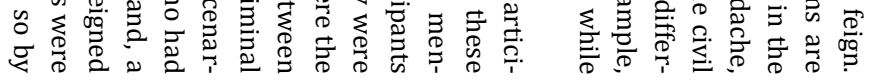
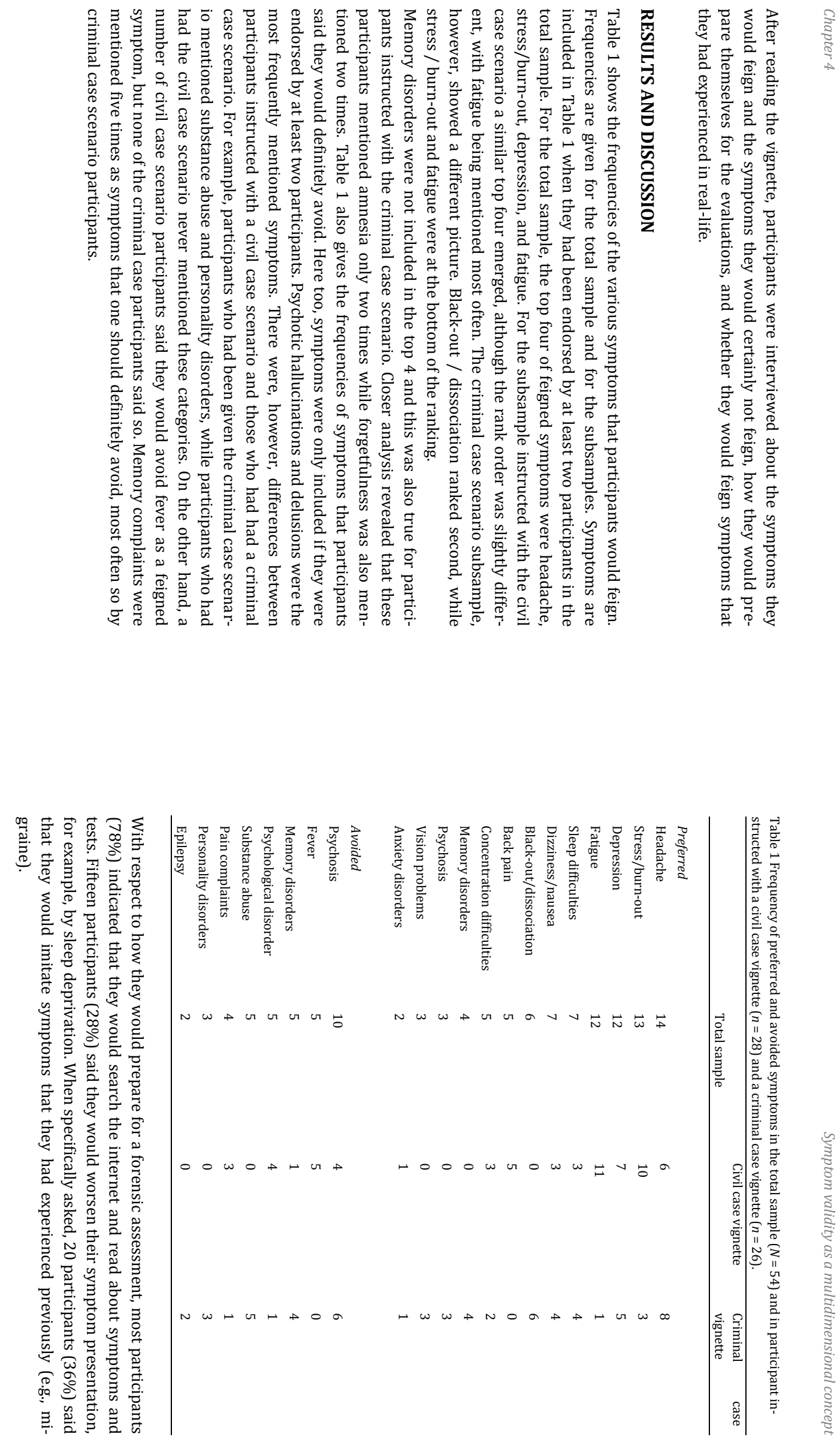


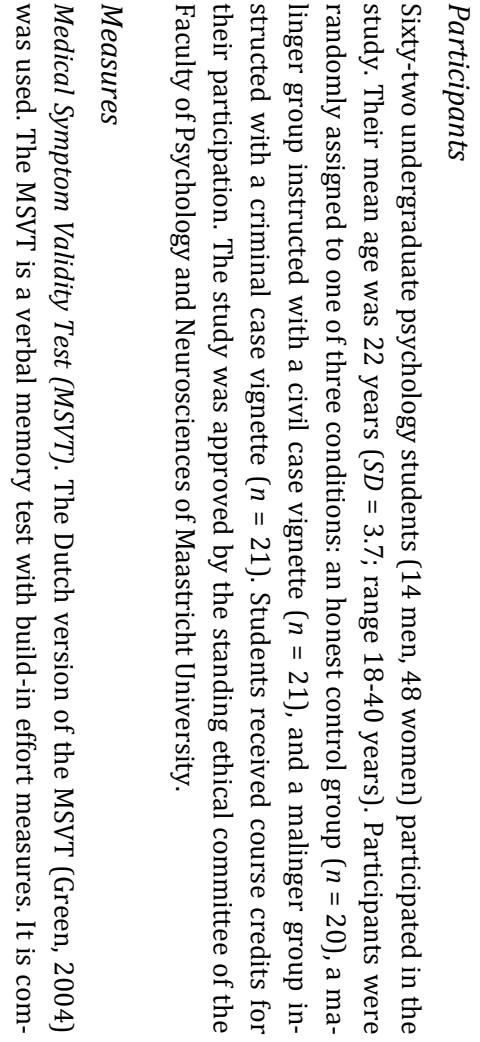

章

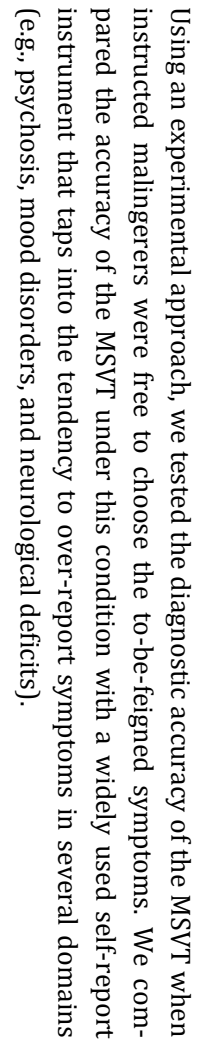

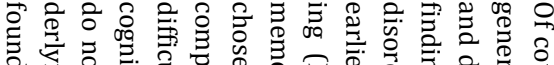

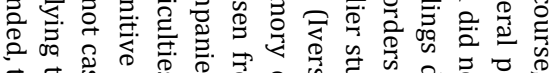
के

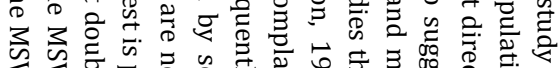

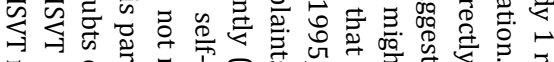
క.

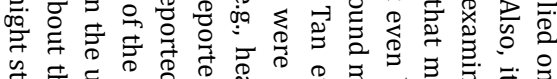

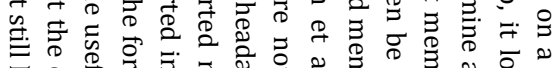

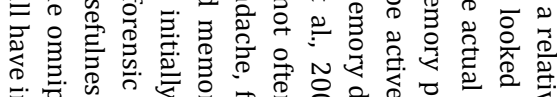

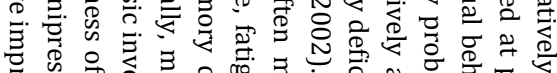

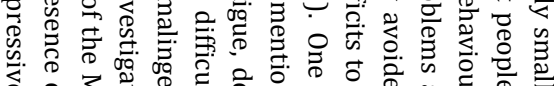

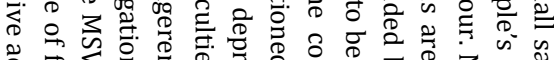

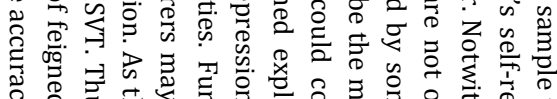

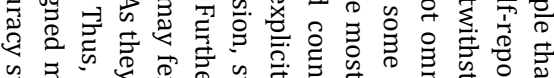

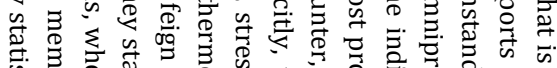

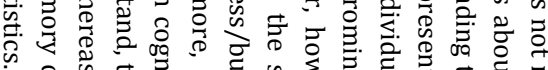

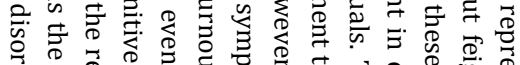

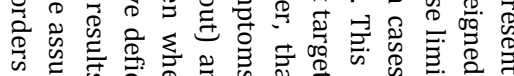

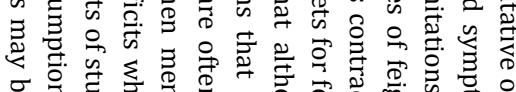

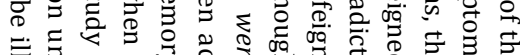

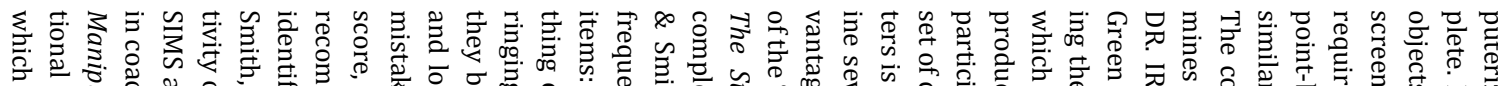

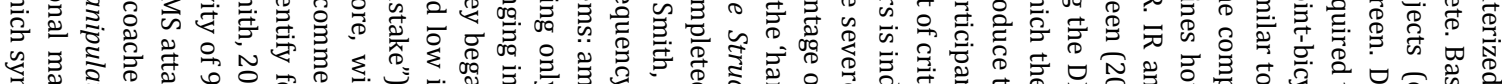

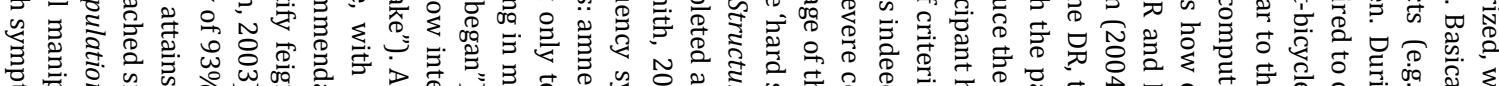

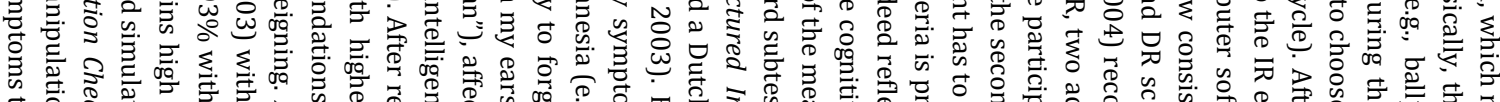

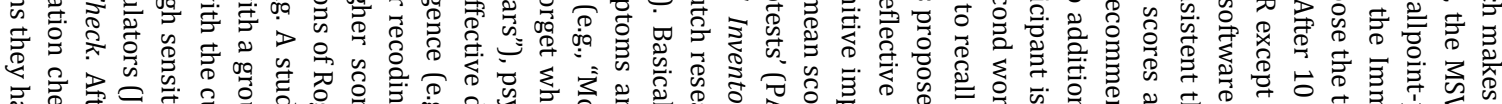

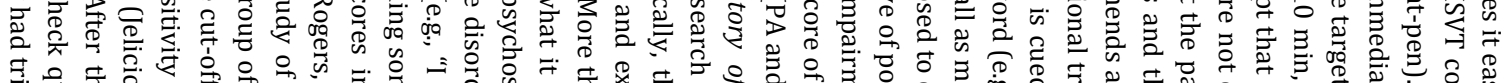

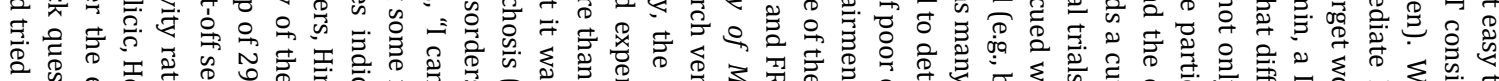

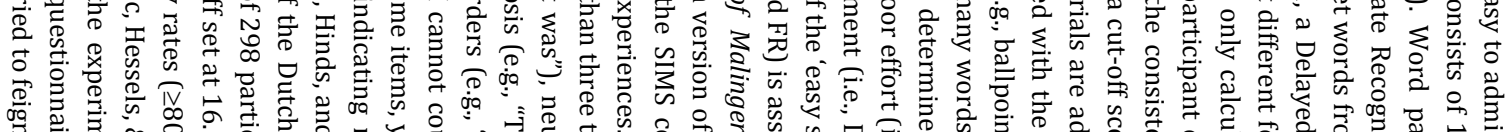

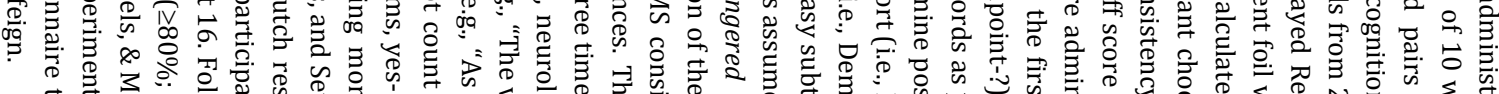

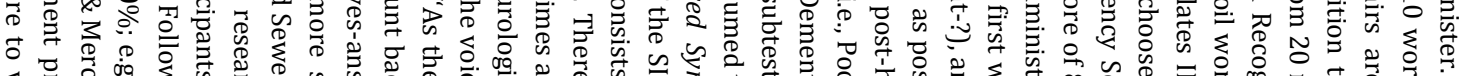

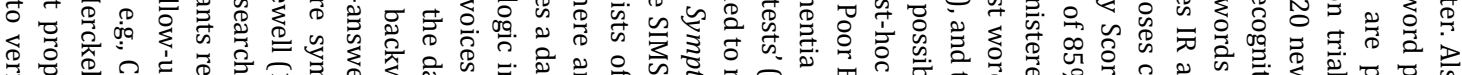

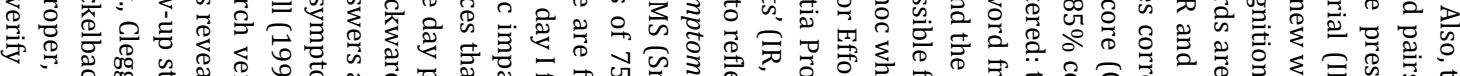

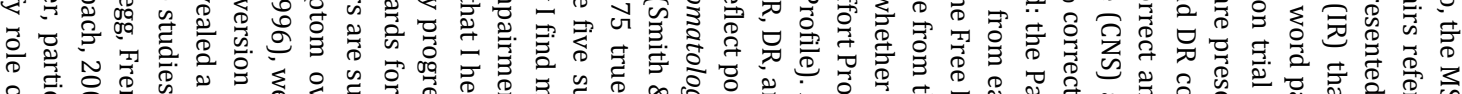

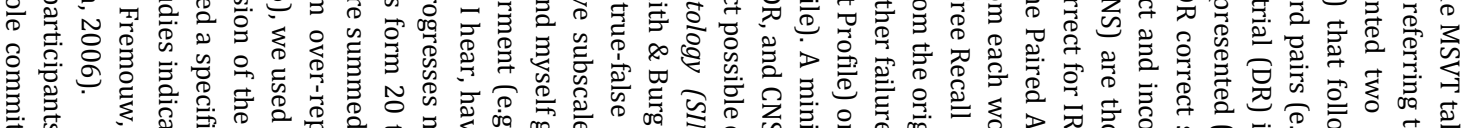

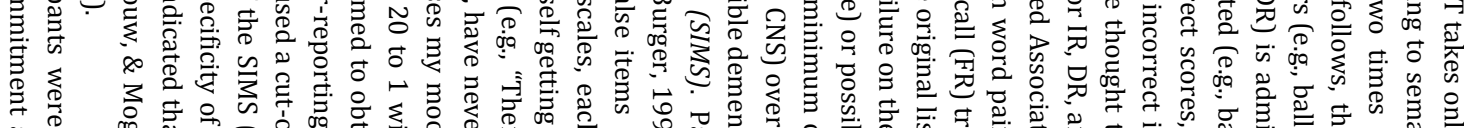

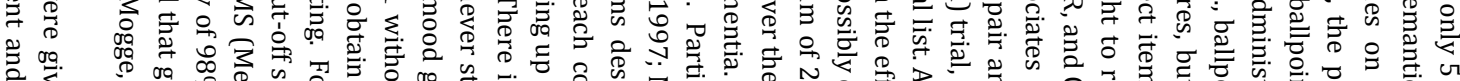

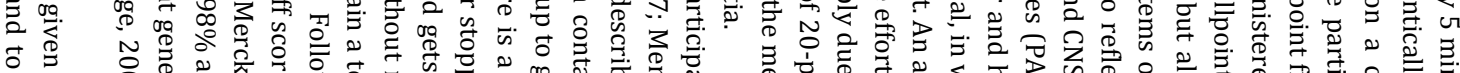

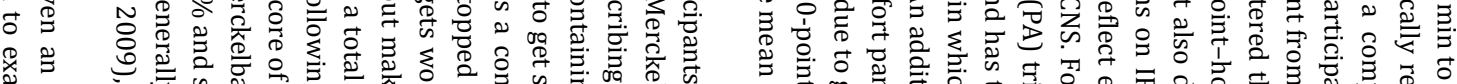

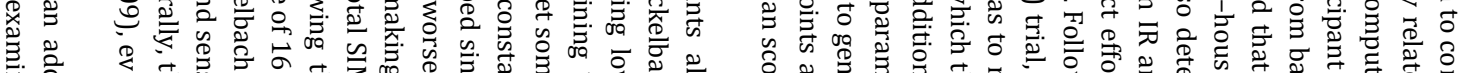

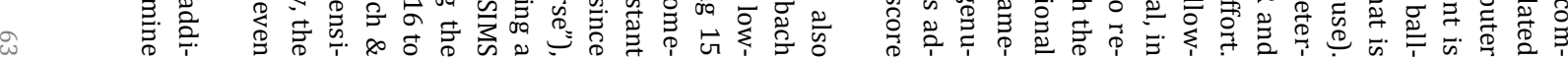


व

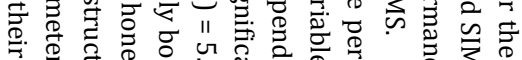

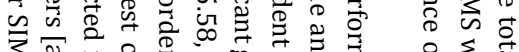

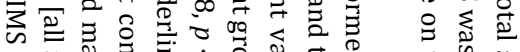

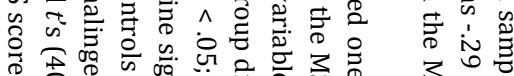

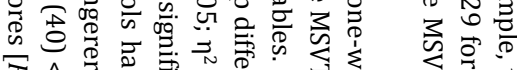

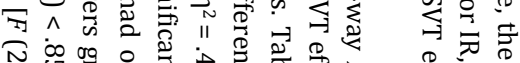

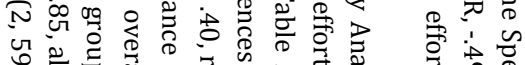

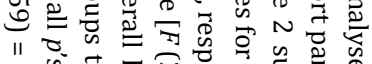
"li

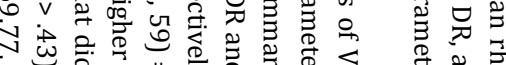

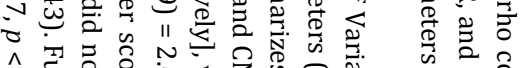

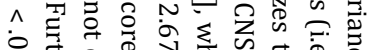
क्षे

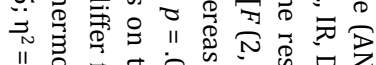

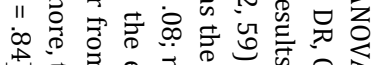

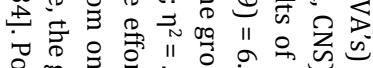

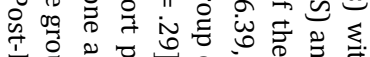

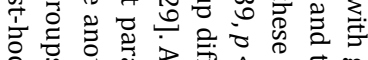

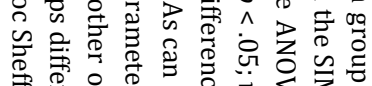

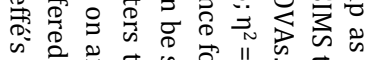

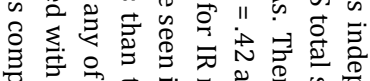

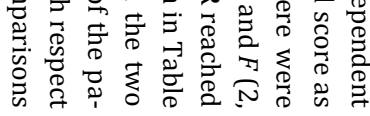

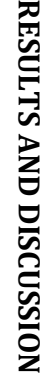

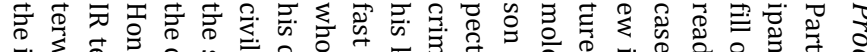

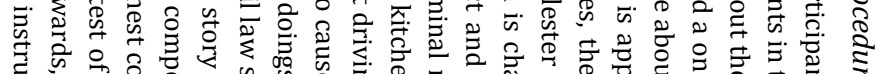

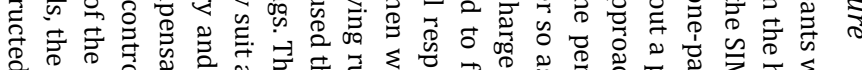

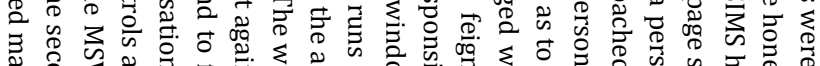

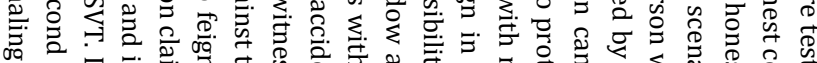

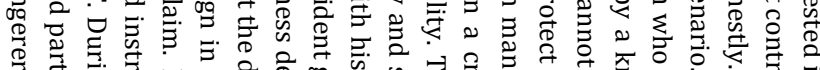

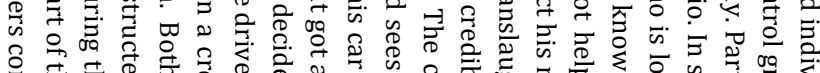

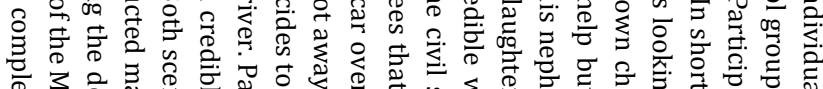
了क

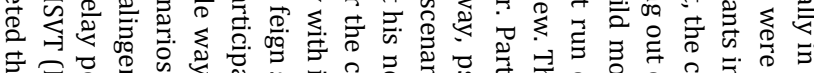

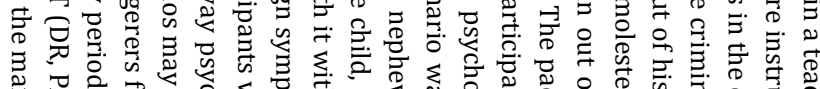

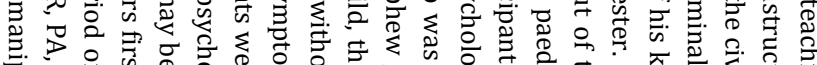

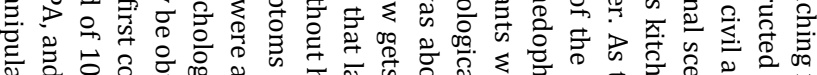

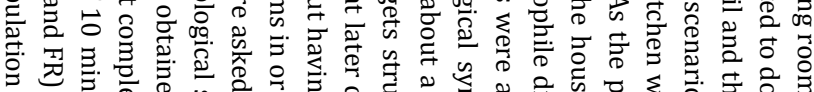

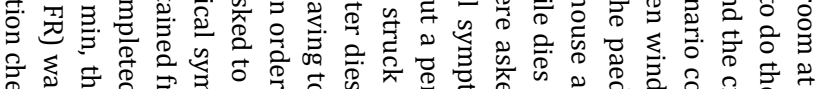

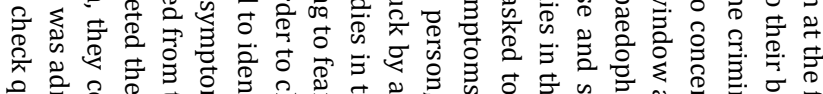

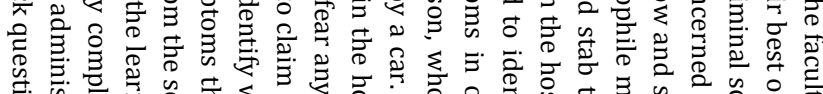

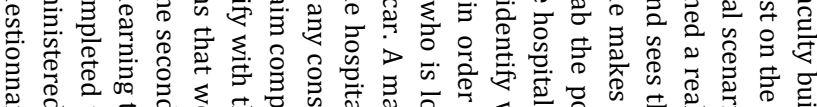

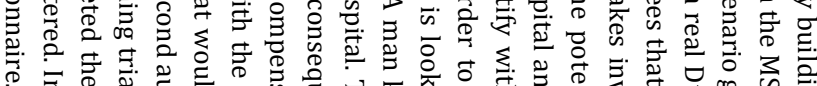

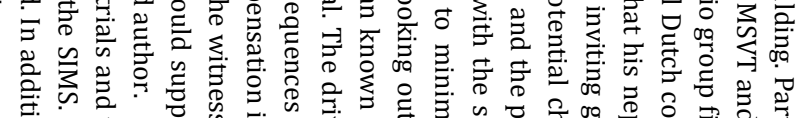

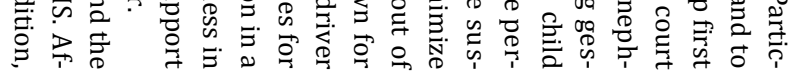

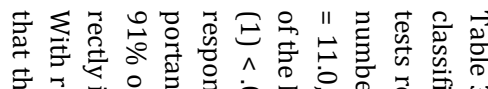

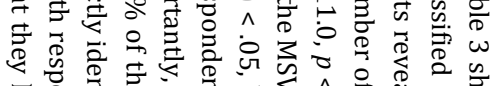

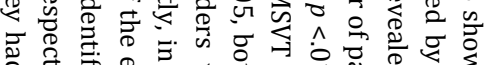

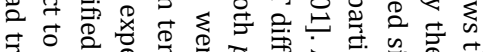

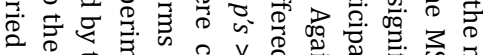

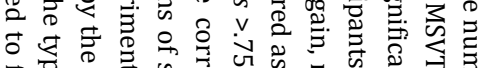
它.

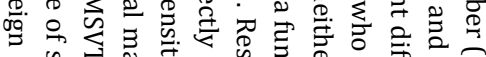

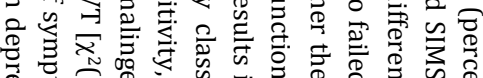

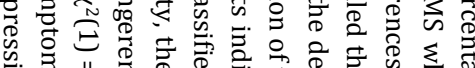
的

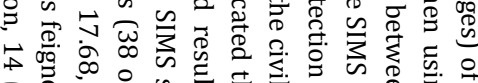

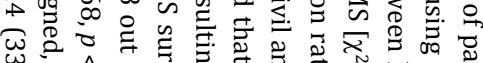

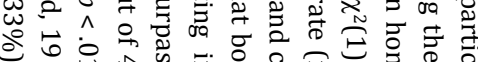

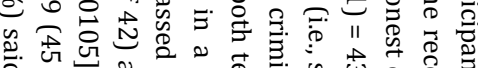

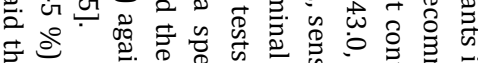

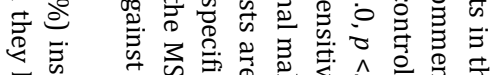

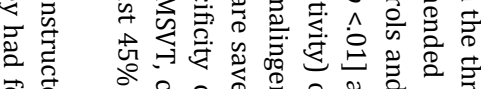

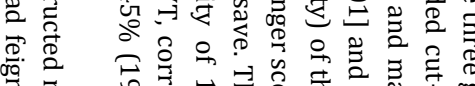

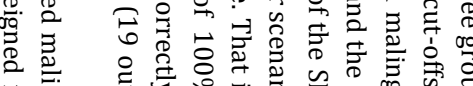

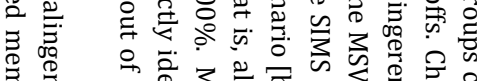

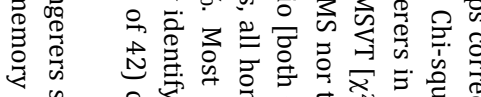
i)

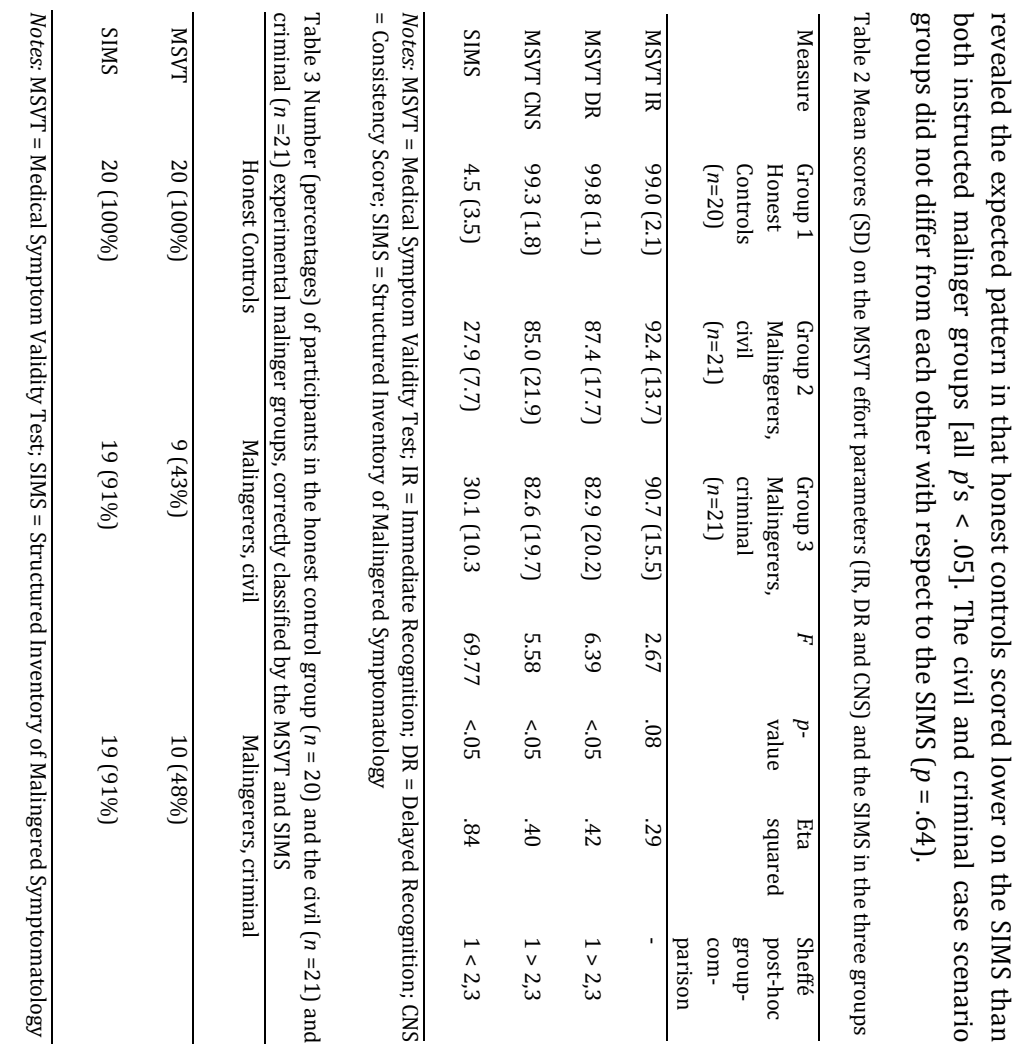




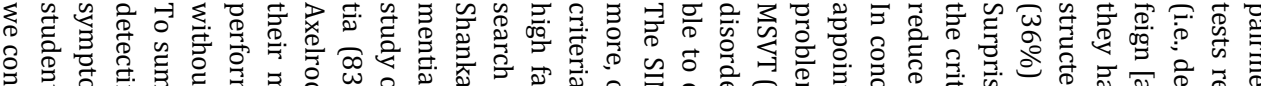

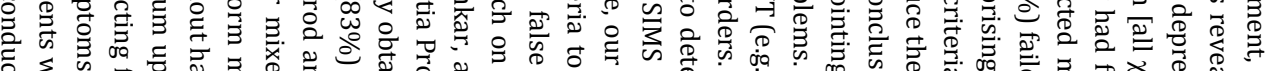

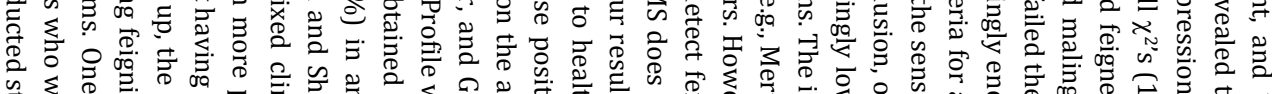

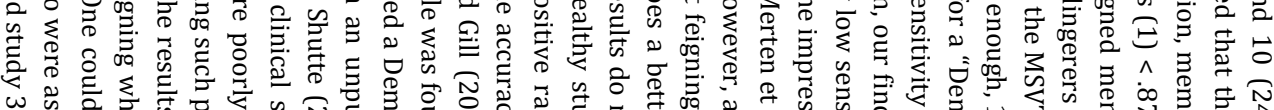

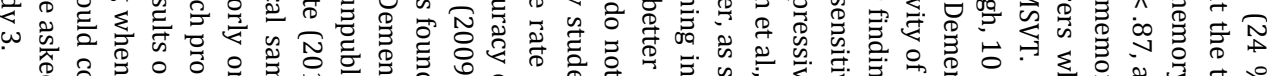

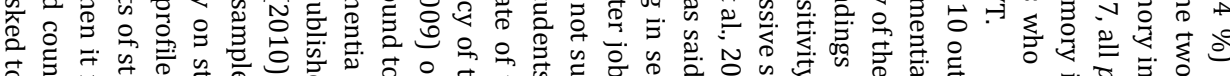

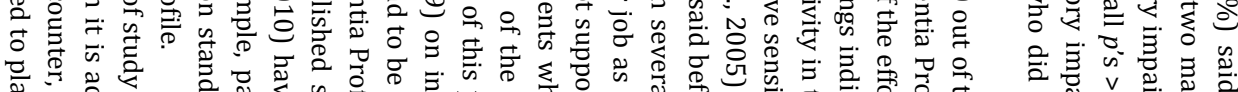

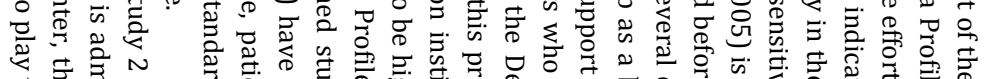

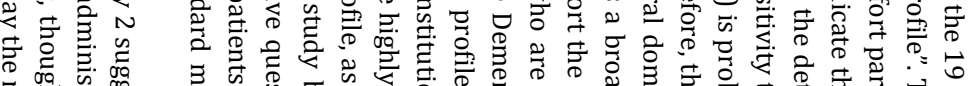
0.

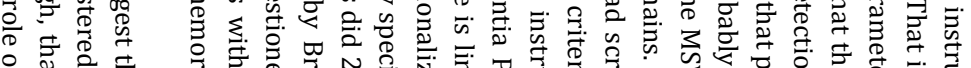

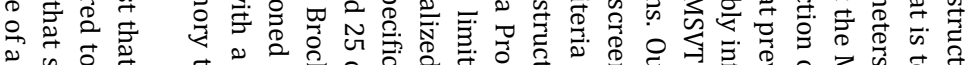

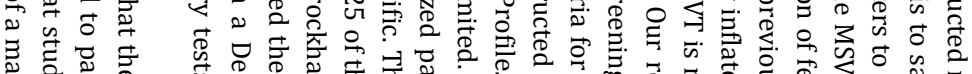

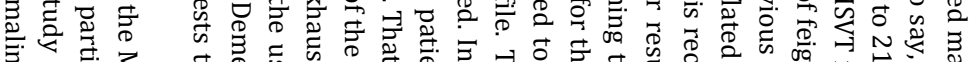

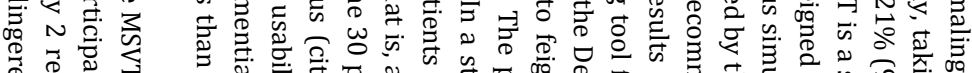

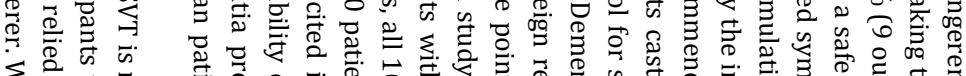

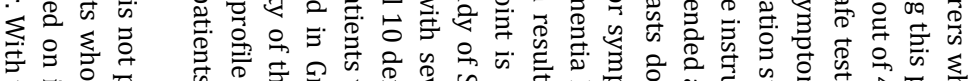

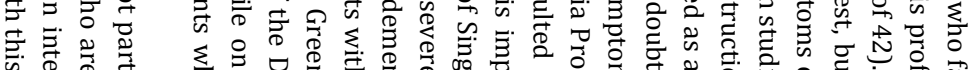

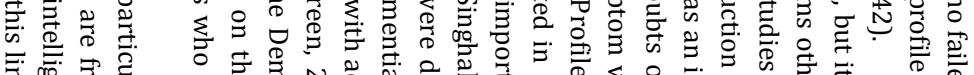

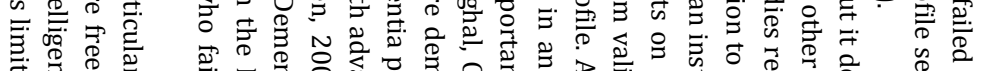

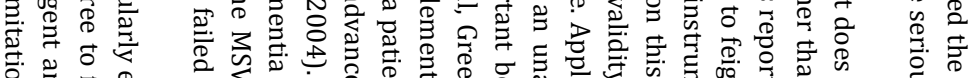

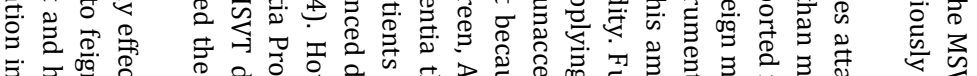

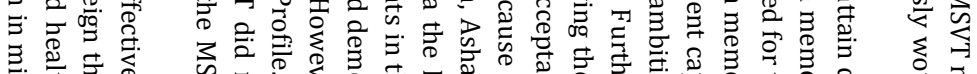

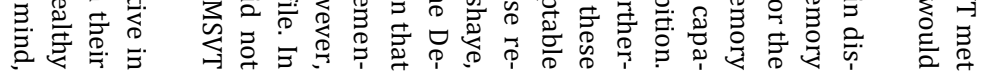

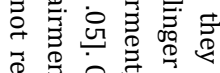

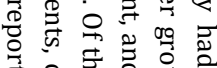

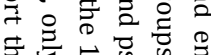

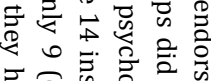

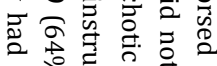
뭉.

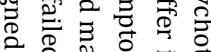
咩

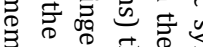

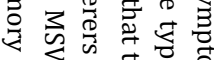

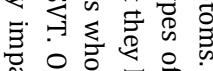
$\stackrel{\infty}{\xi}$ 劳 品

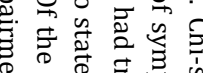

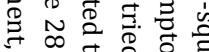

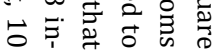

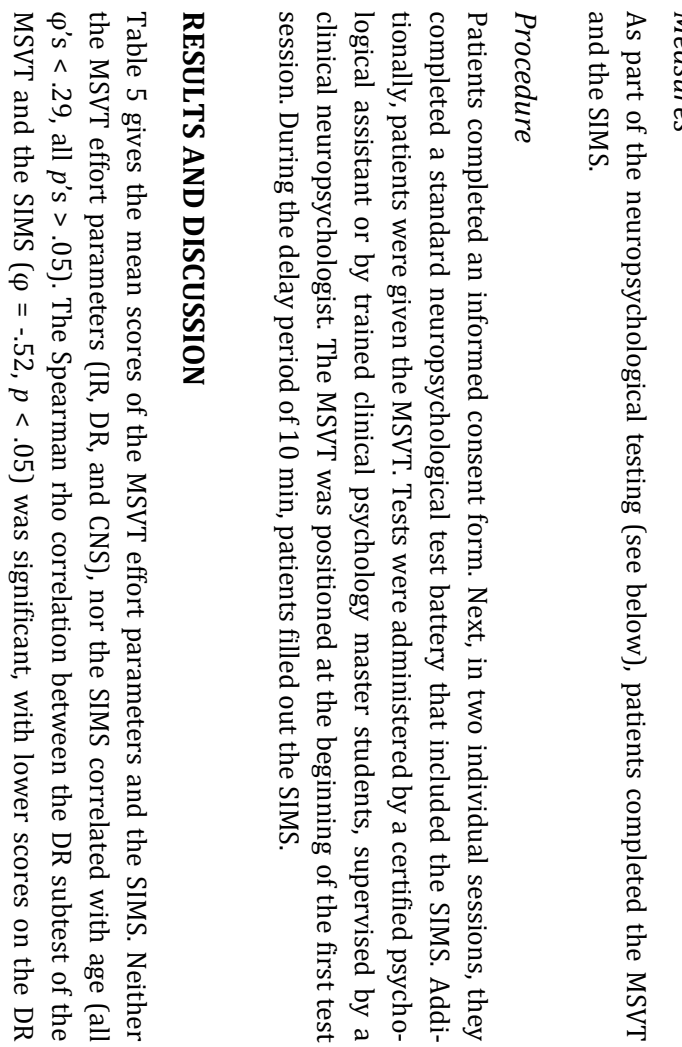

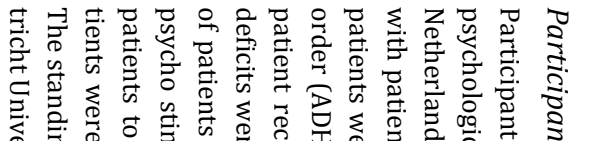

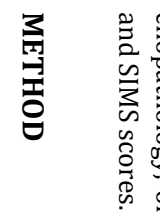

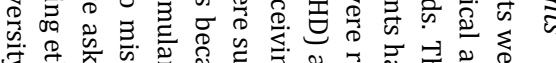

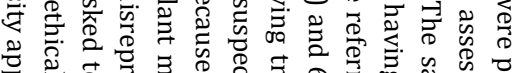

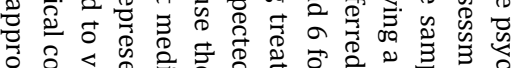

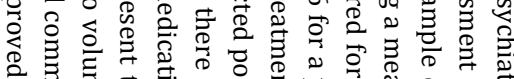

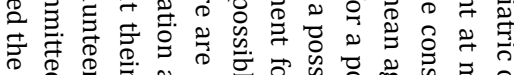

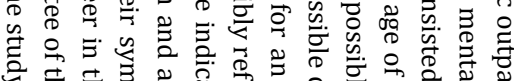

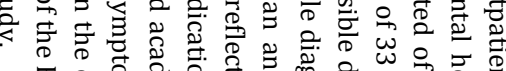

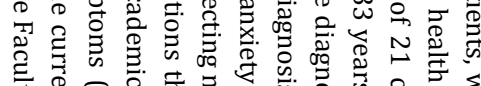

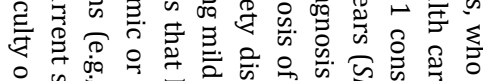

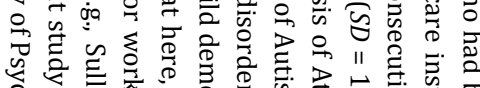

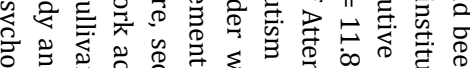

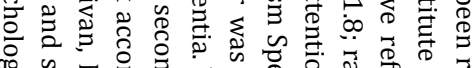

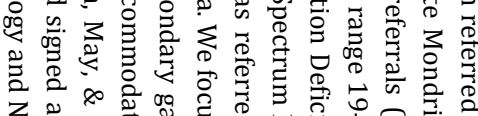

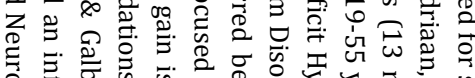

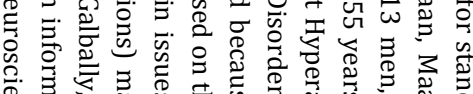

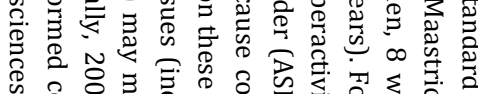

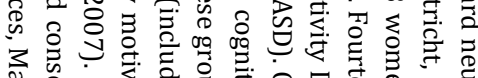

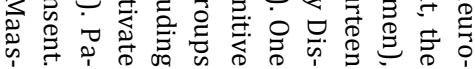




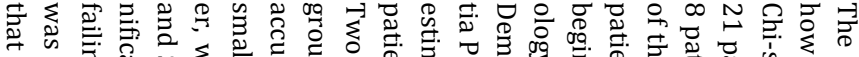

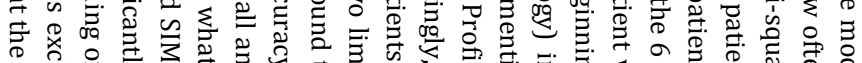

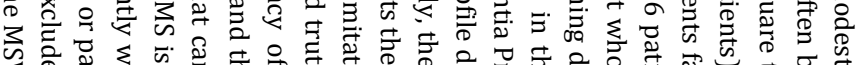

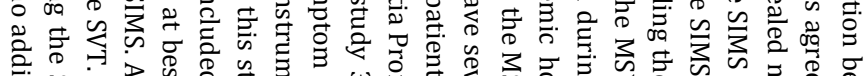

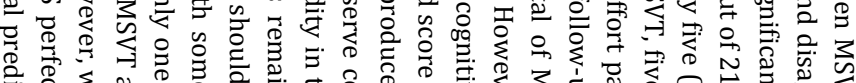

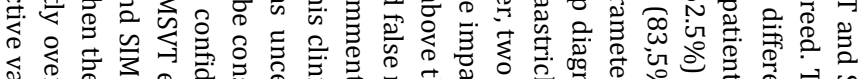

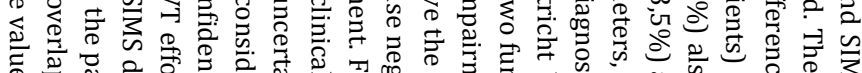

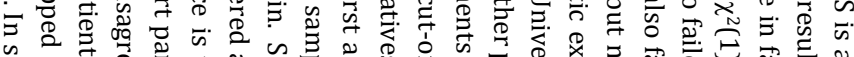

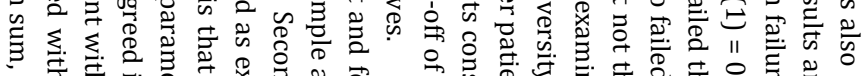

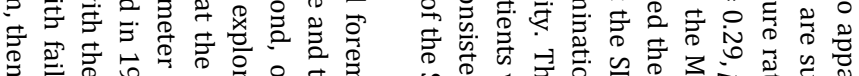

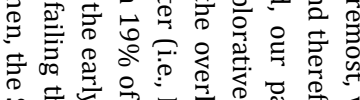

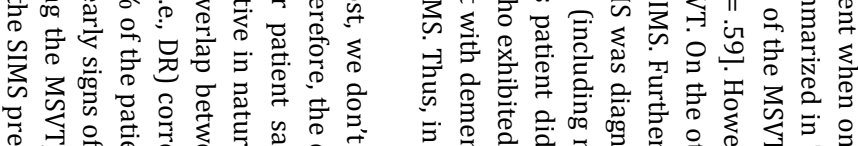

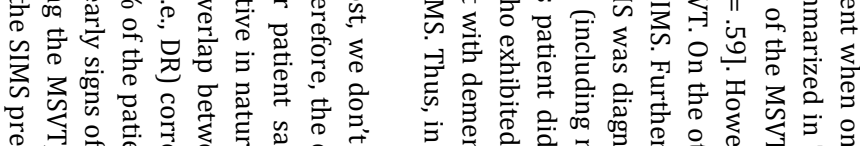

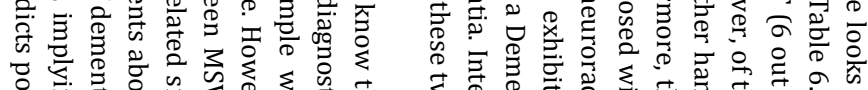

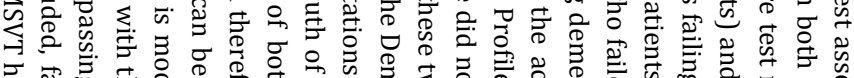

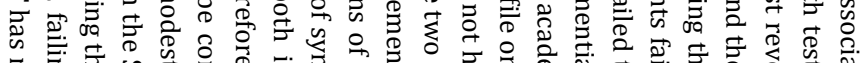

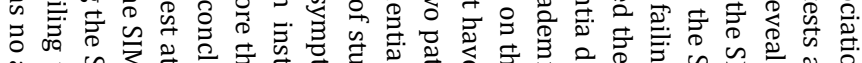

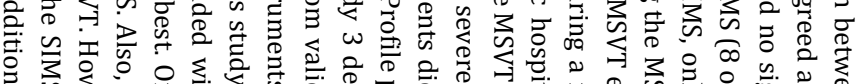

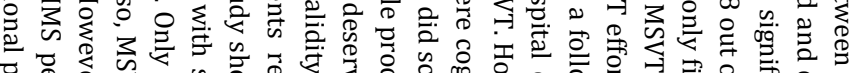

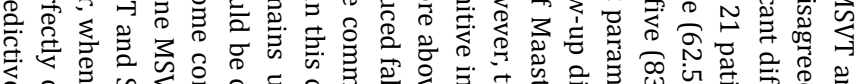

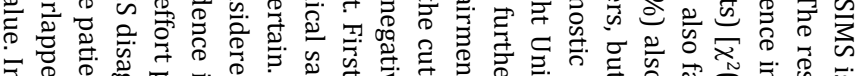
.

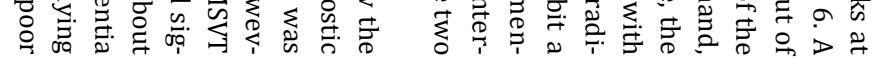
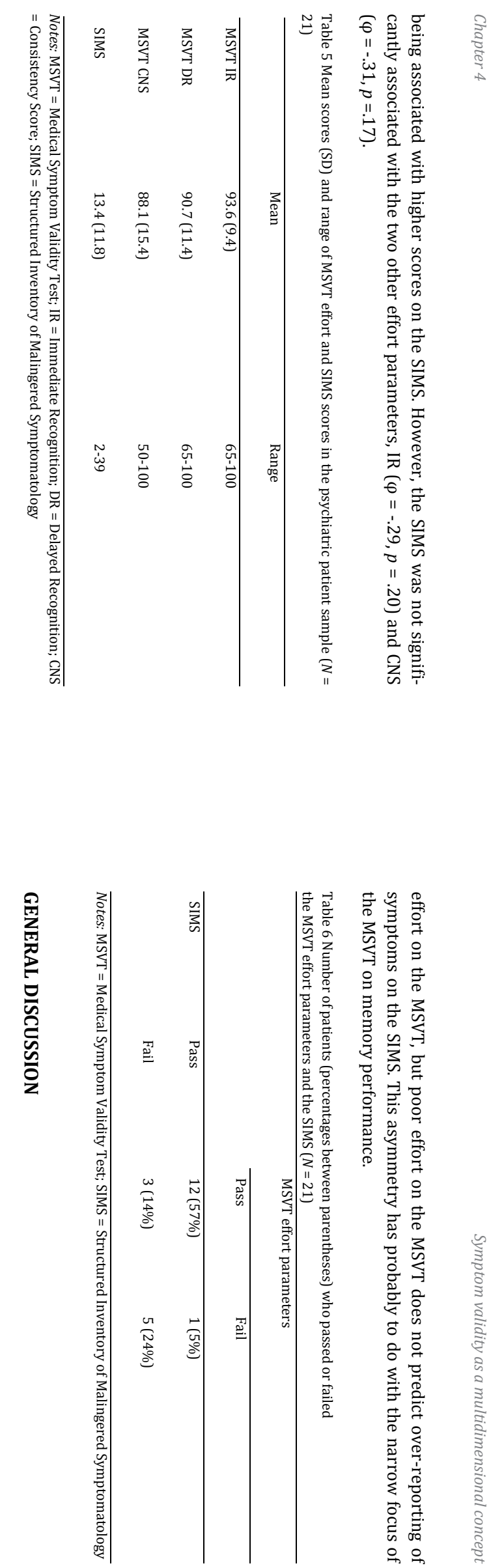

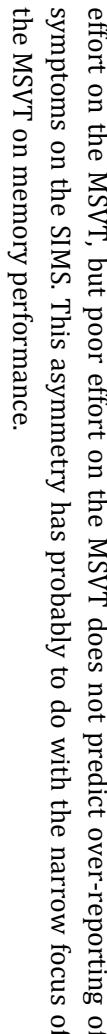

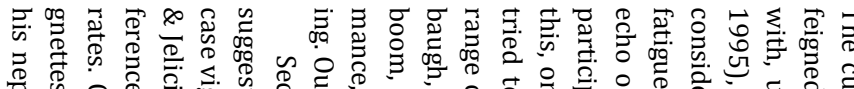
密 o

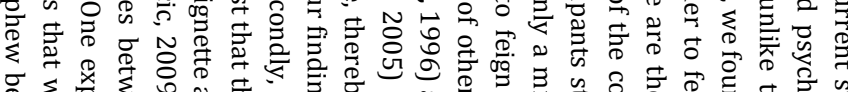

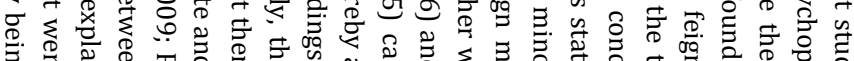

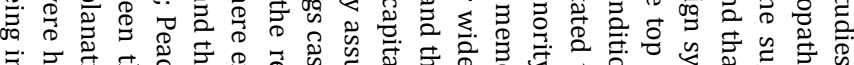

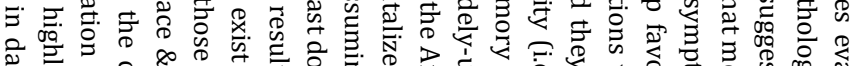

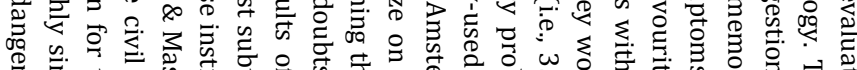

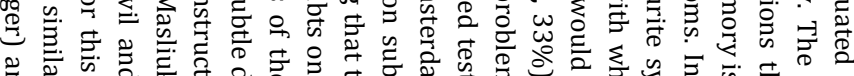

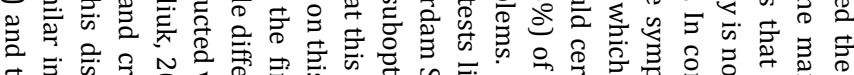

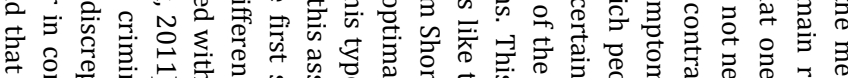

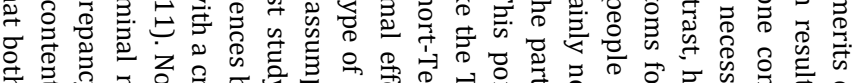

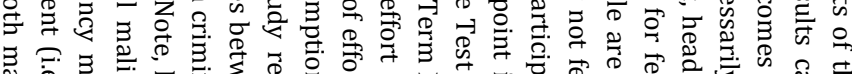

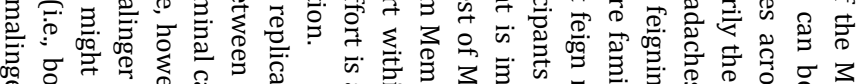

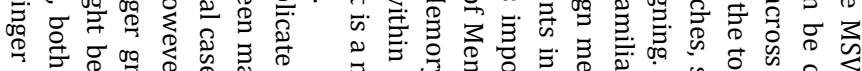
og

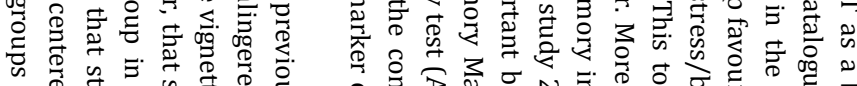

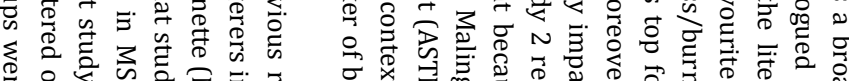

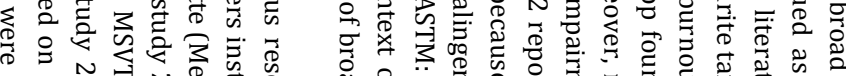

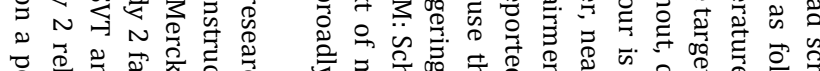

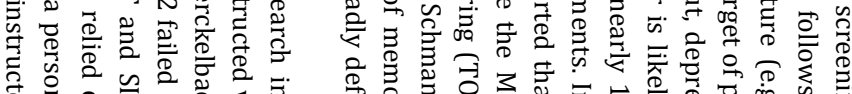

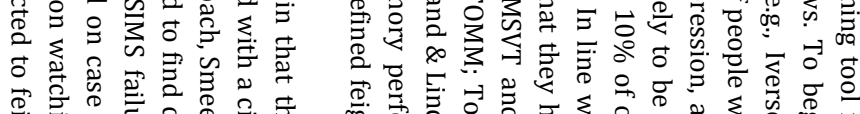

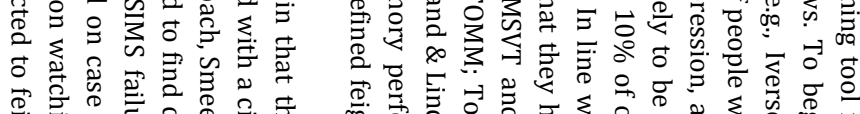

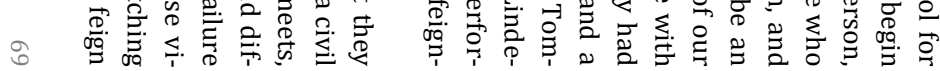




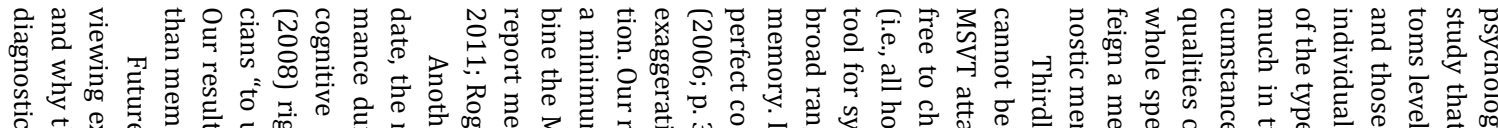

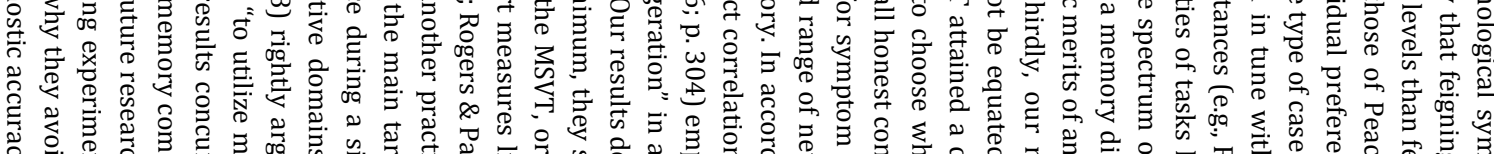

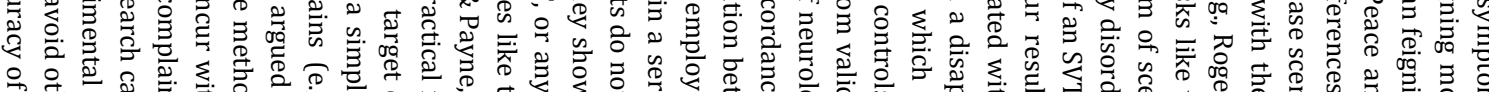

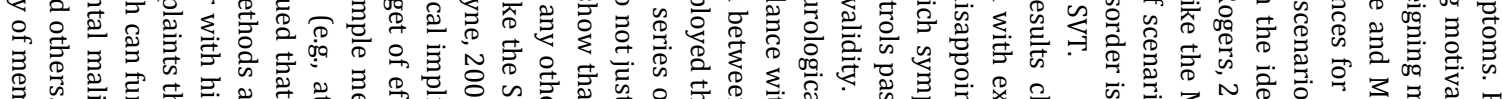

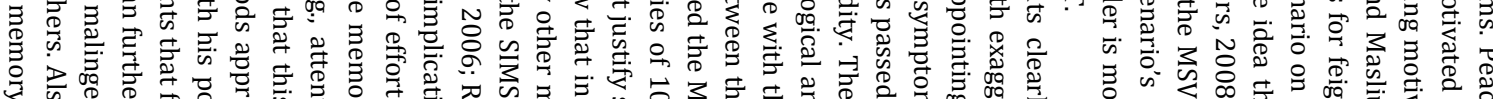

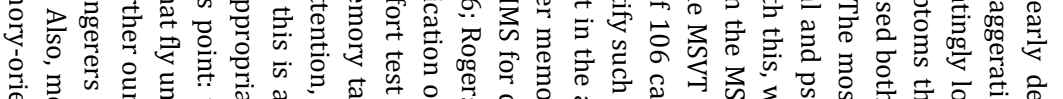

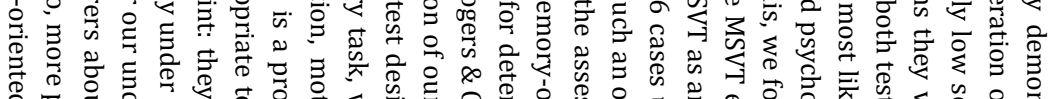

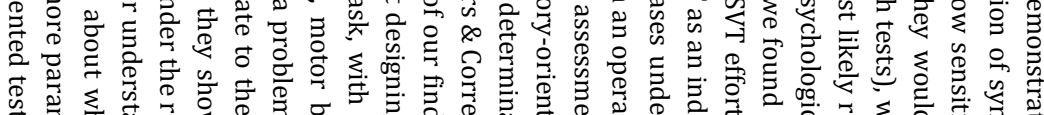

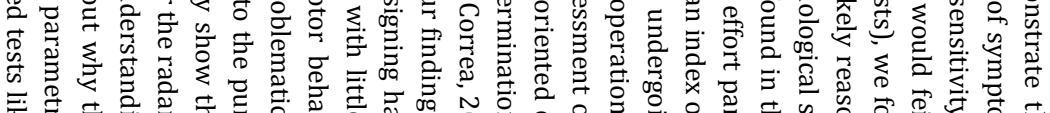

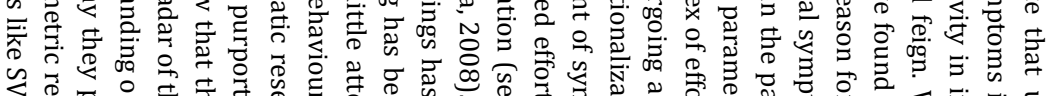

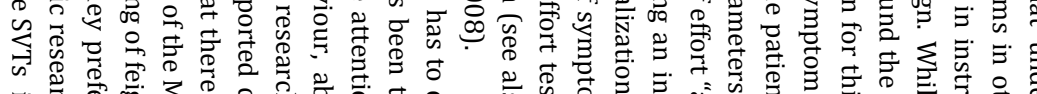

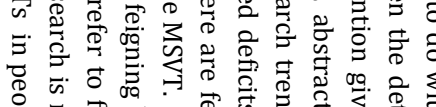

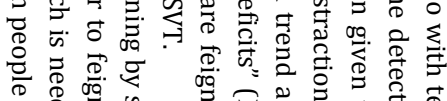

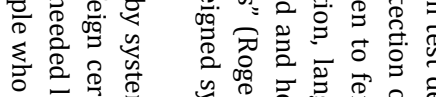

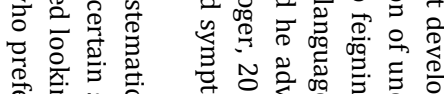

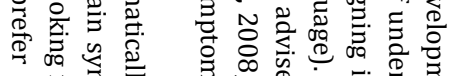

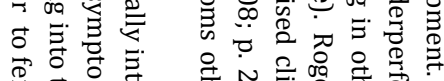

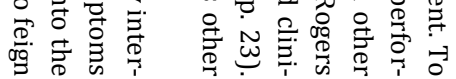

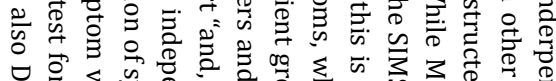

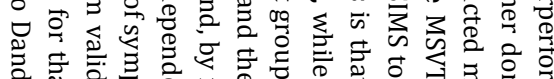

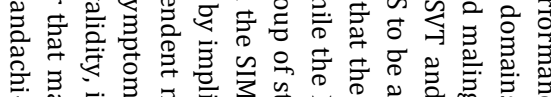

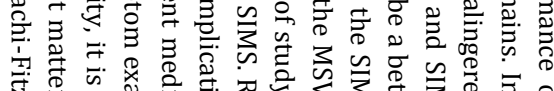

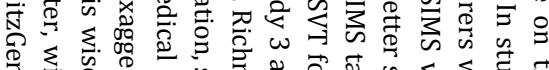

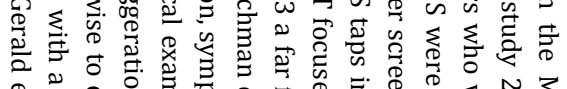
O

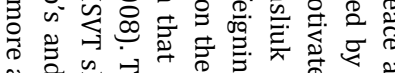

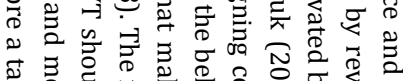

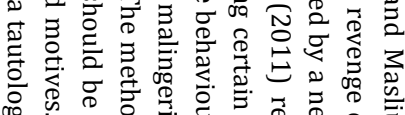

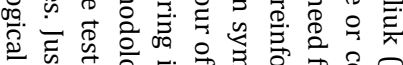

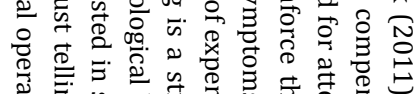

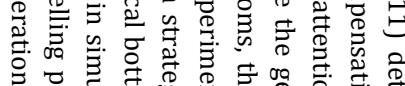

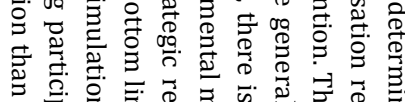

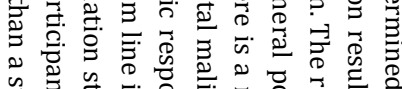

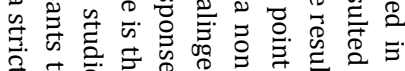

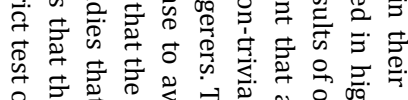

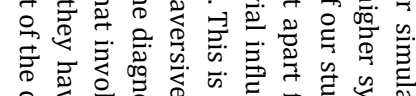

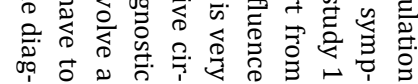

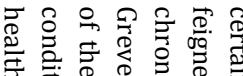

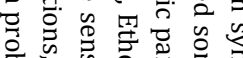
年

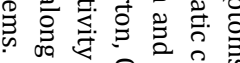

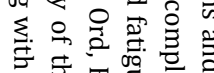

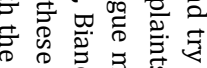
के 0 을. 를. के क्ष

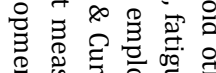

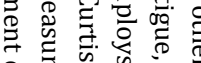
$\circ$ 象

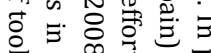

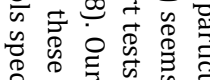

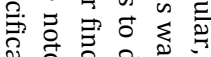

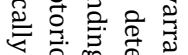

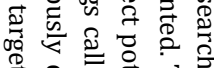

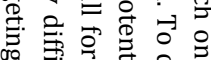

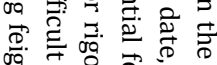

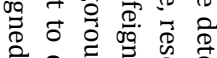

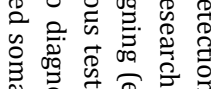
总. 

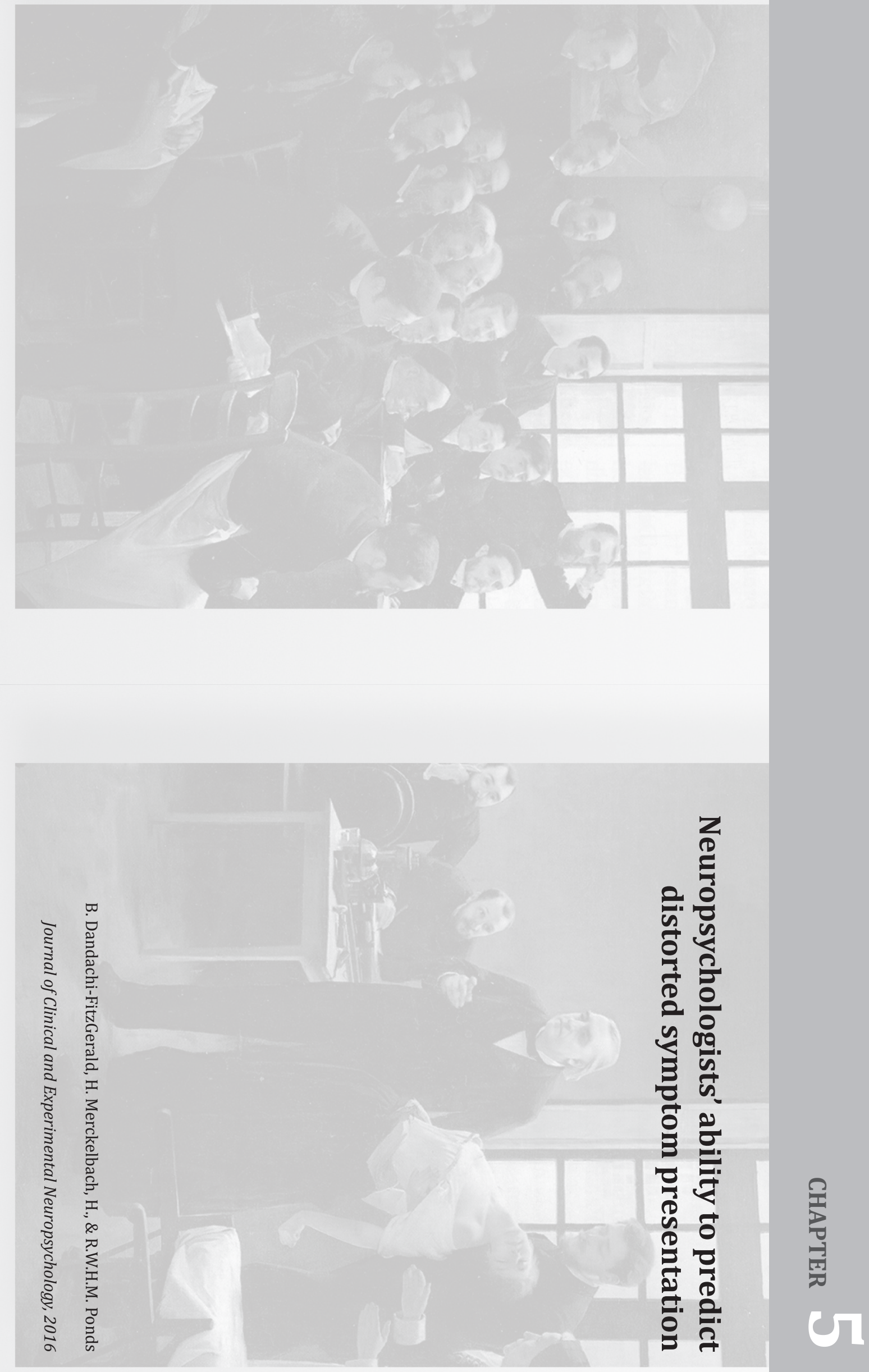


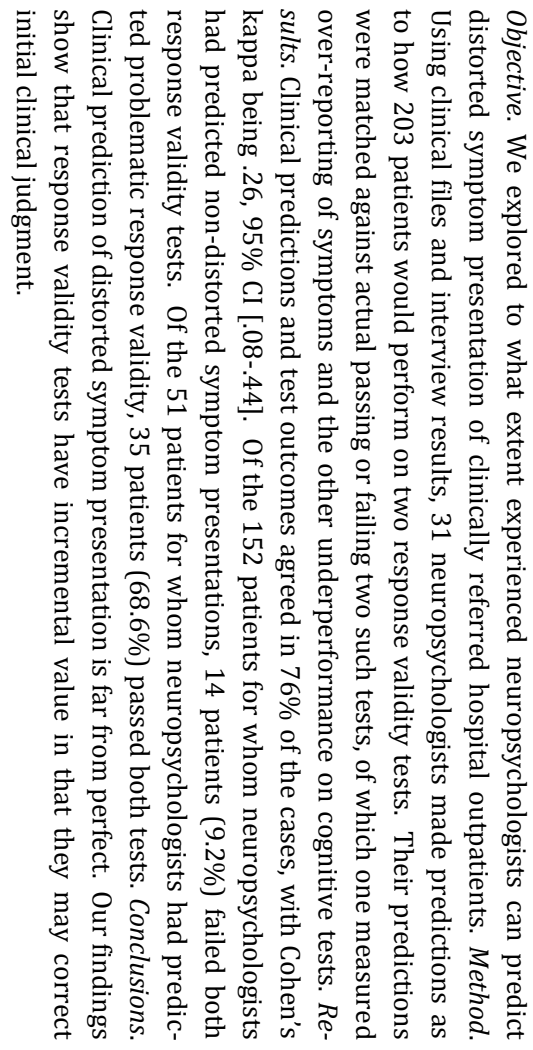

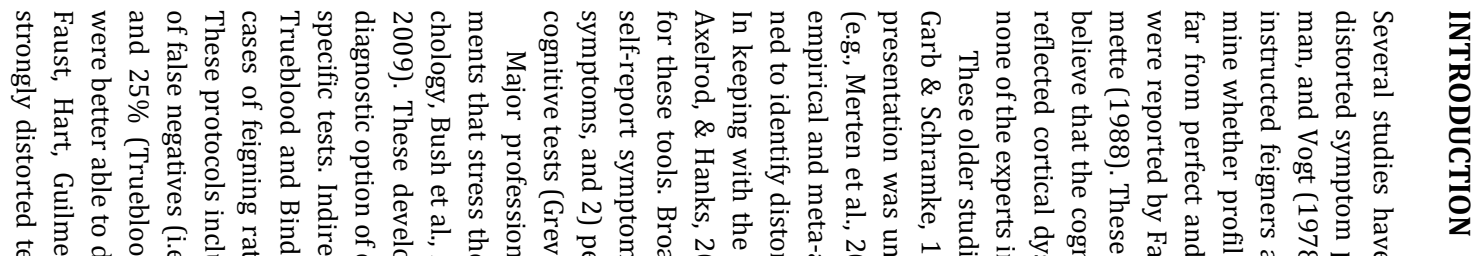

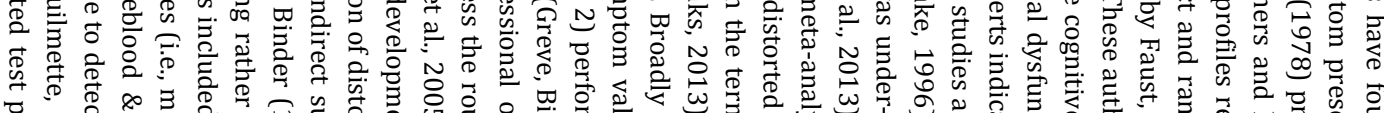

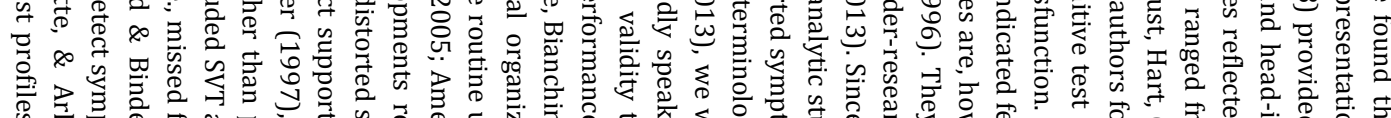

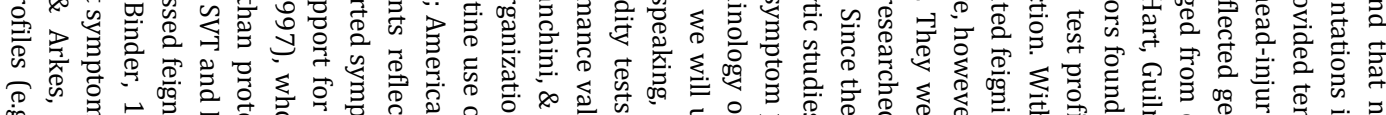
9. ris

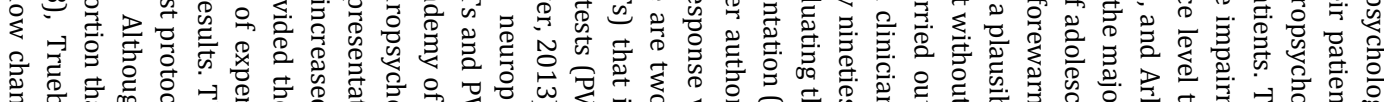
Mun

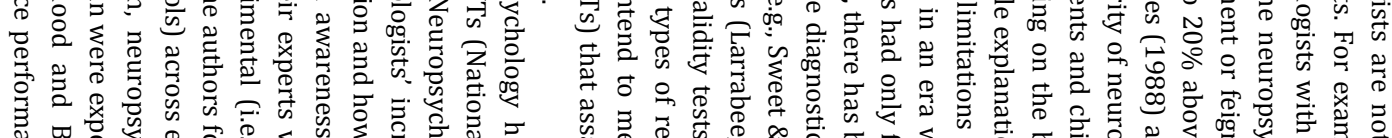

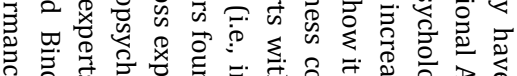

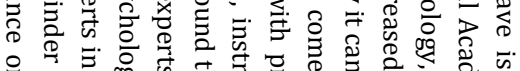

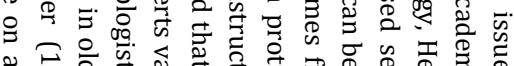

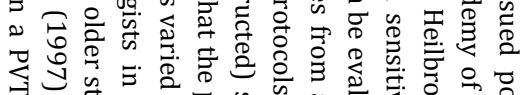

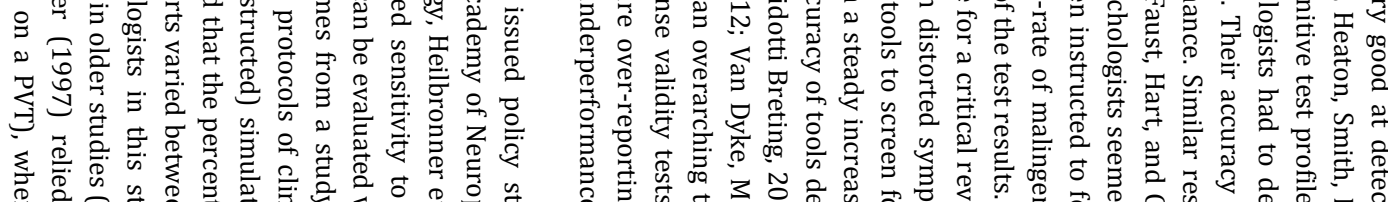

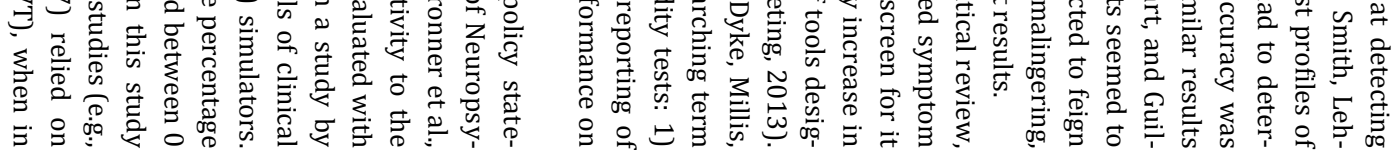

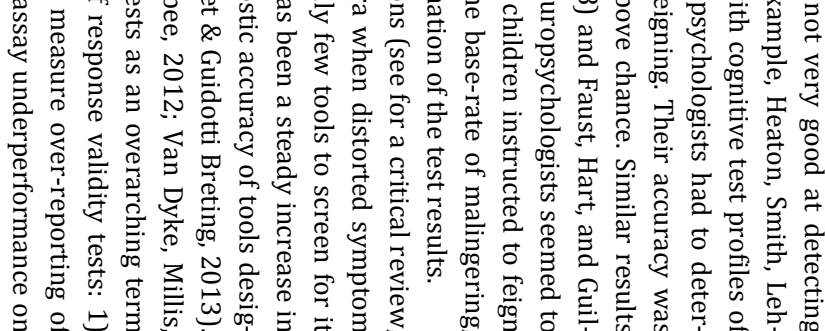



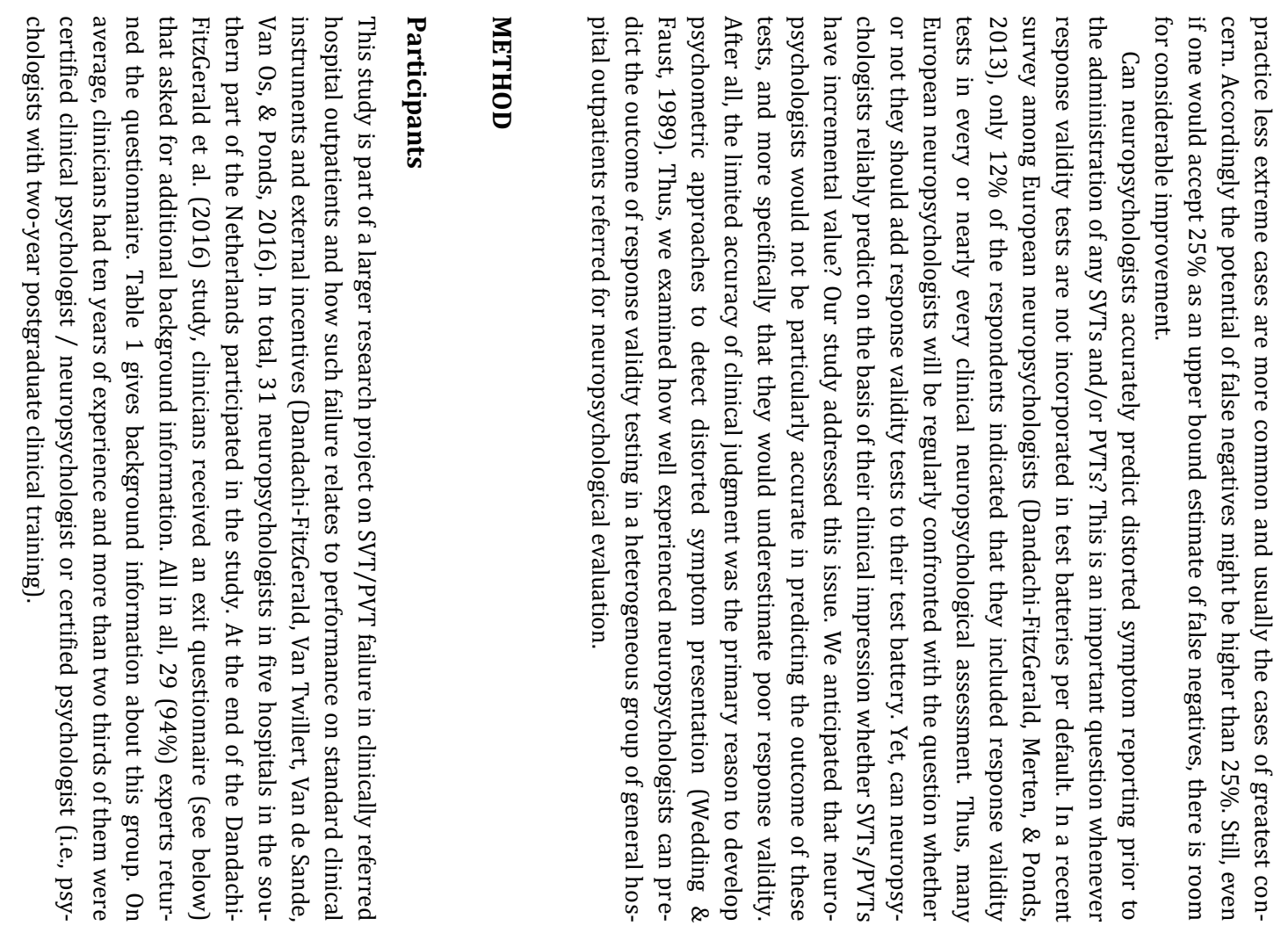

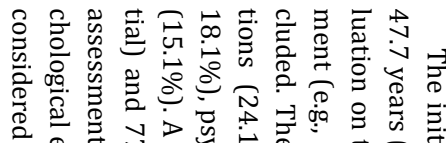

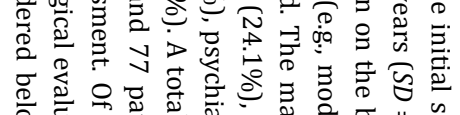

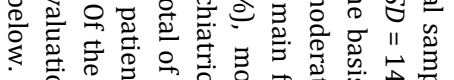

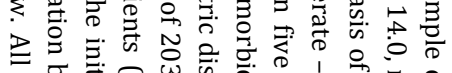

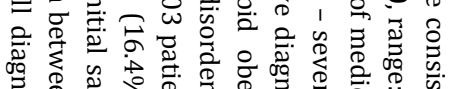

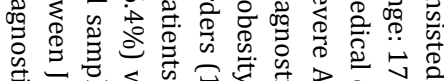

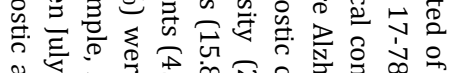

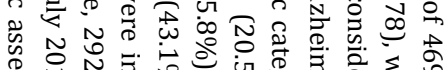

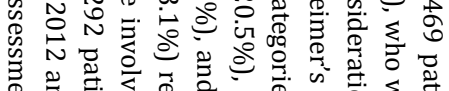

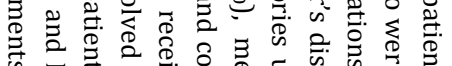
-

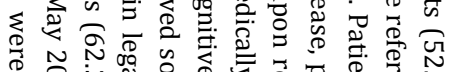

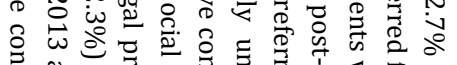

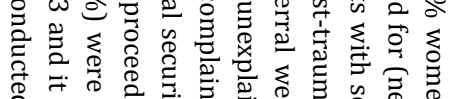

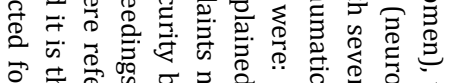

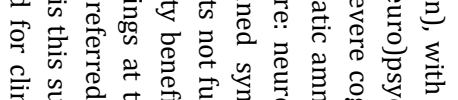

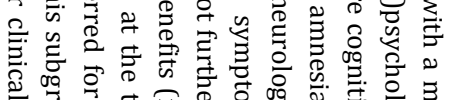

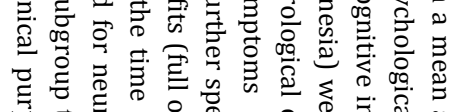

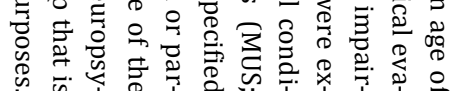

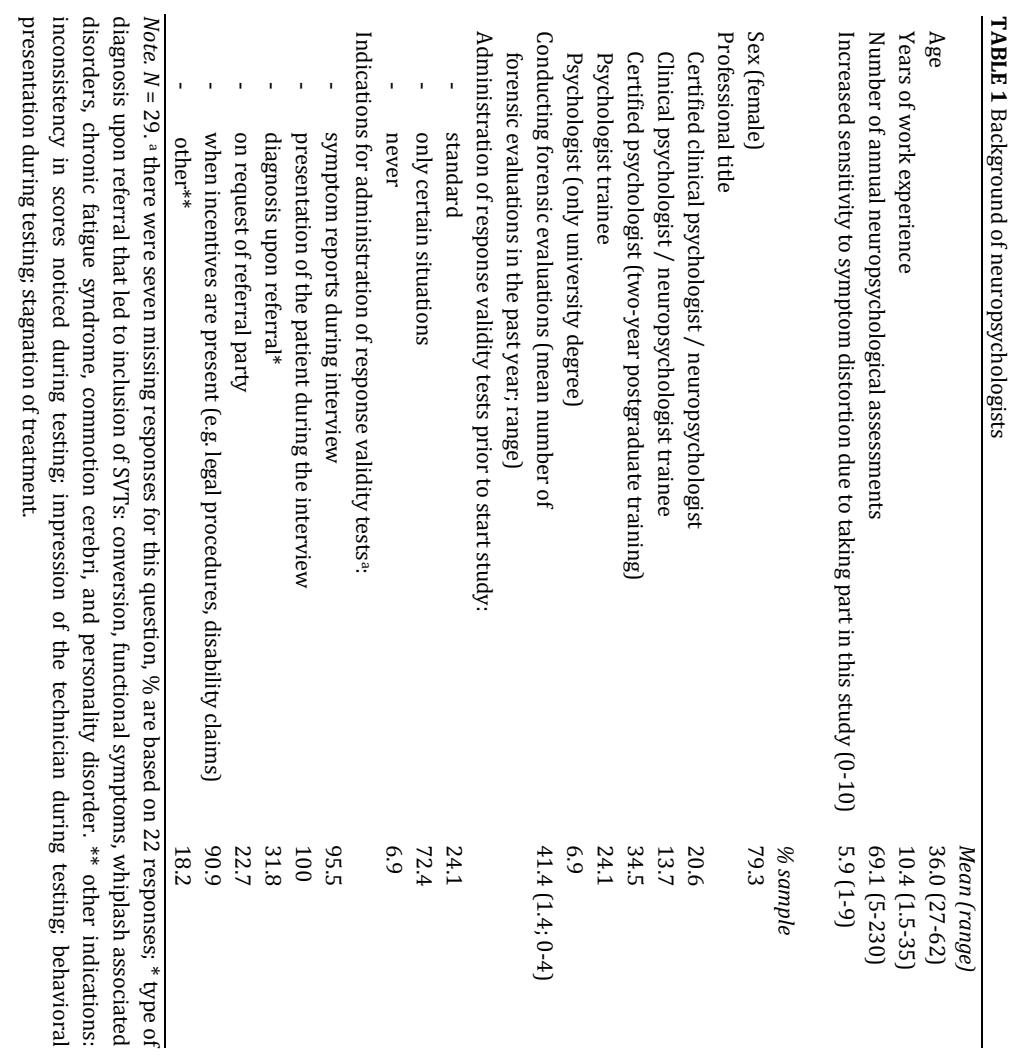



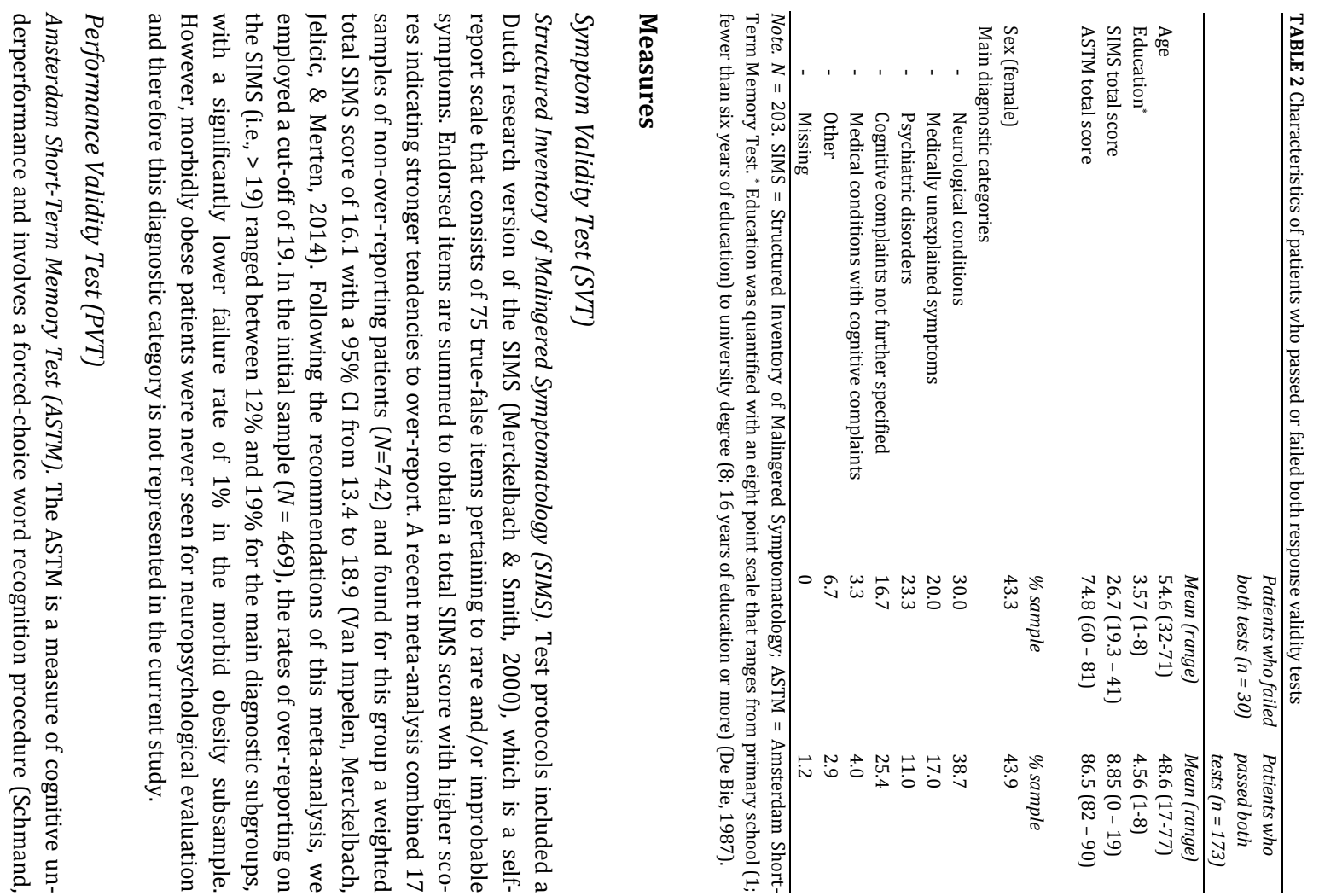


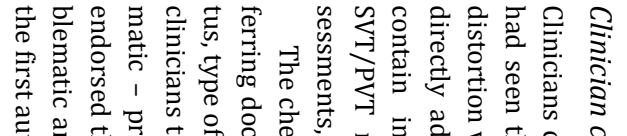

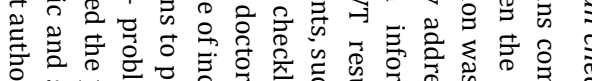

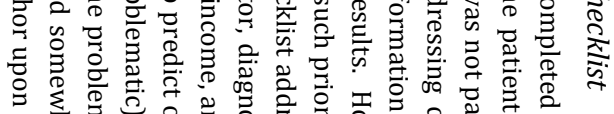

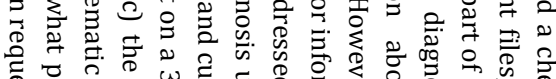

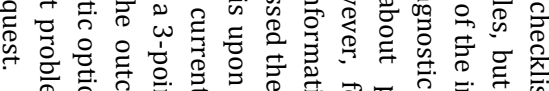

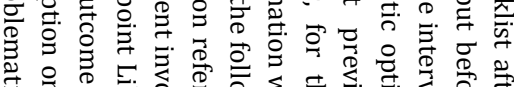

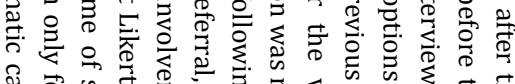

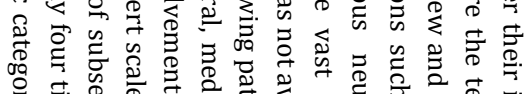

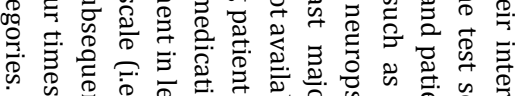

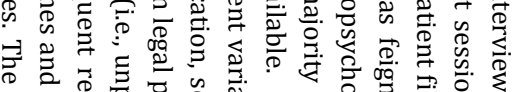

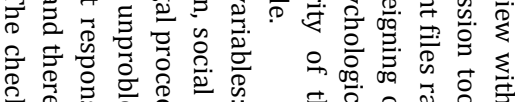

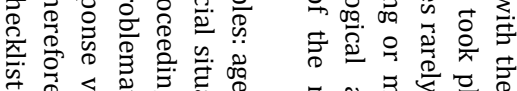

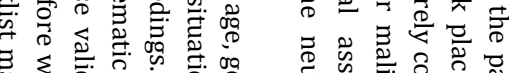

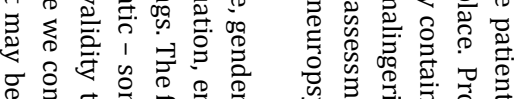

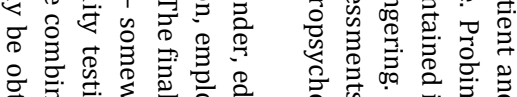

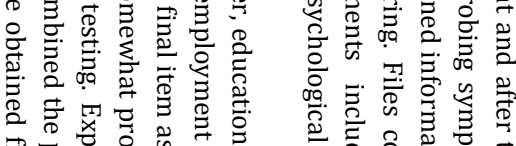

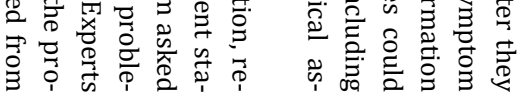

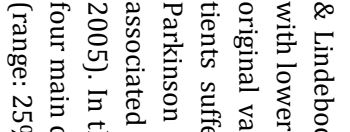

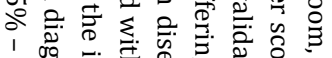

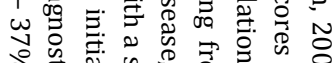
㝴究.

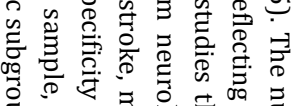

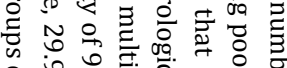

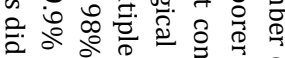

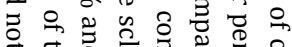

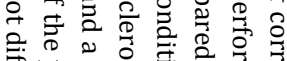

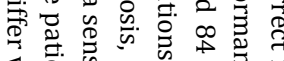

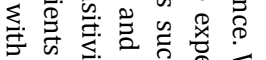

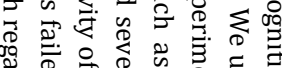

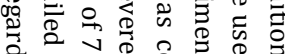

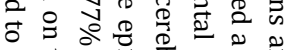

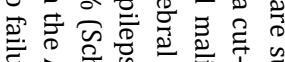

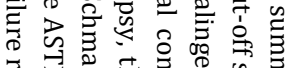

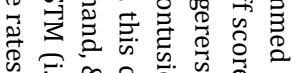

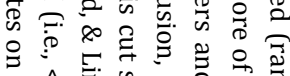

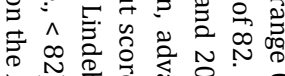

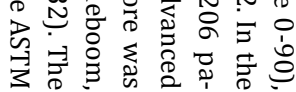

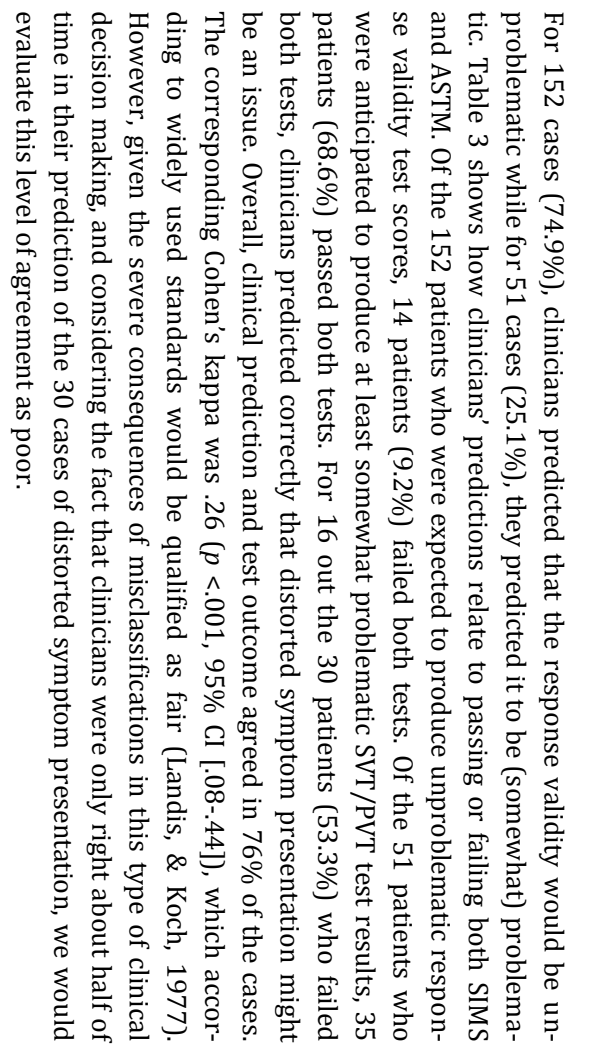

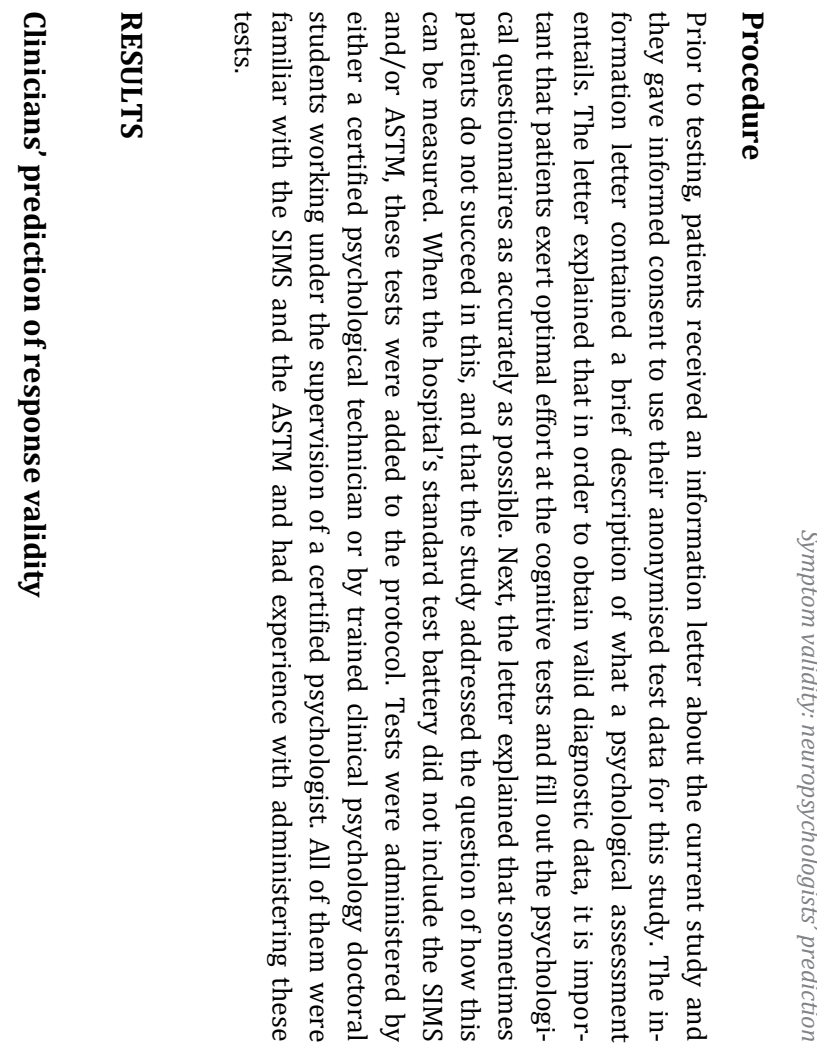




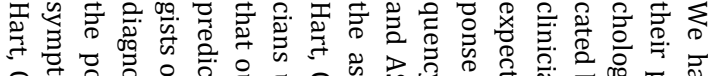

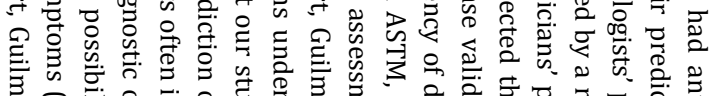

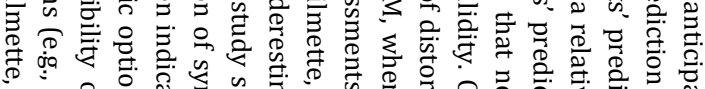

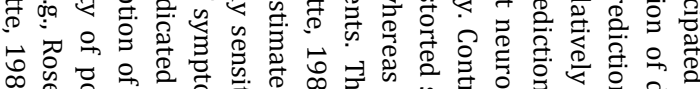

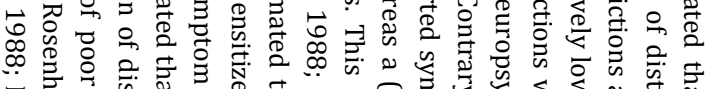

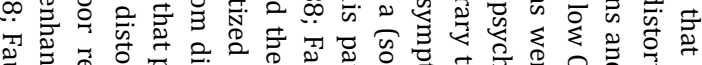

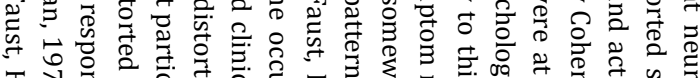

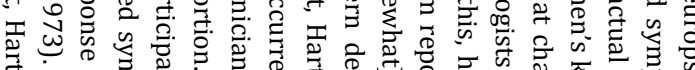

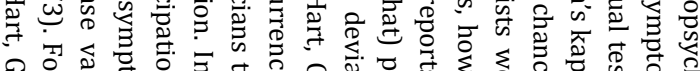

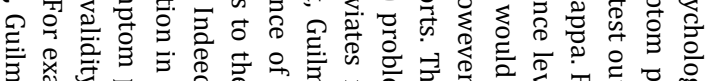

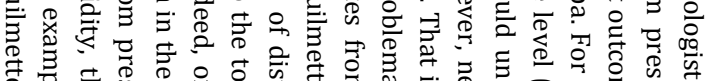

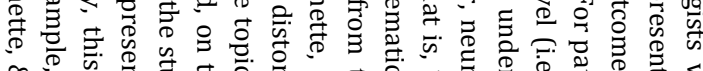

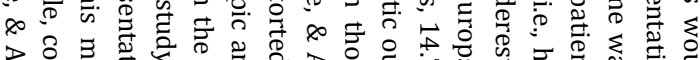

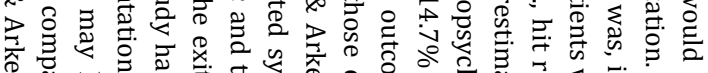

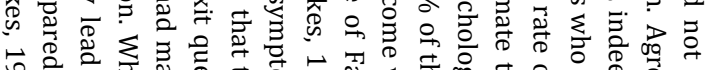

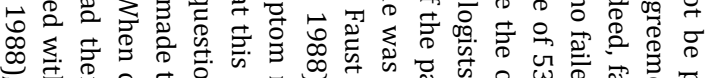

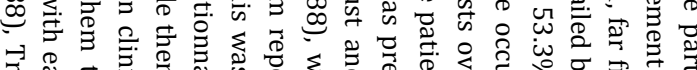

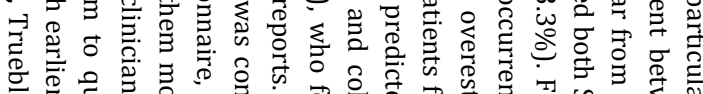

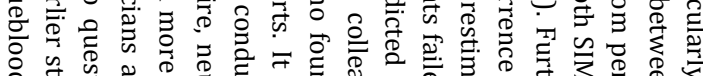

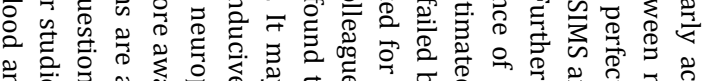

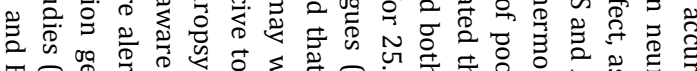

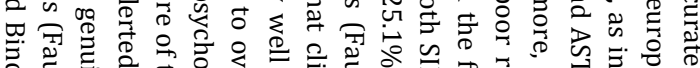

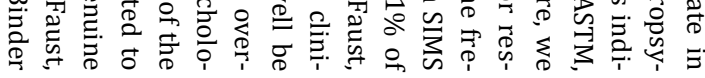
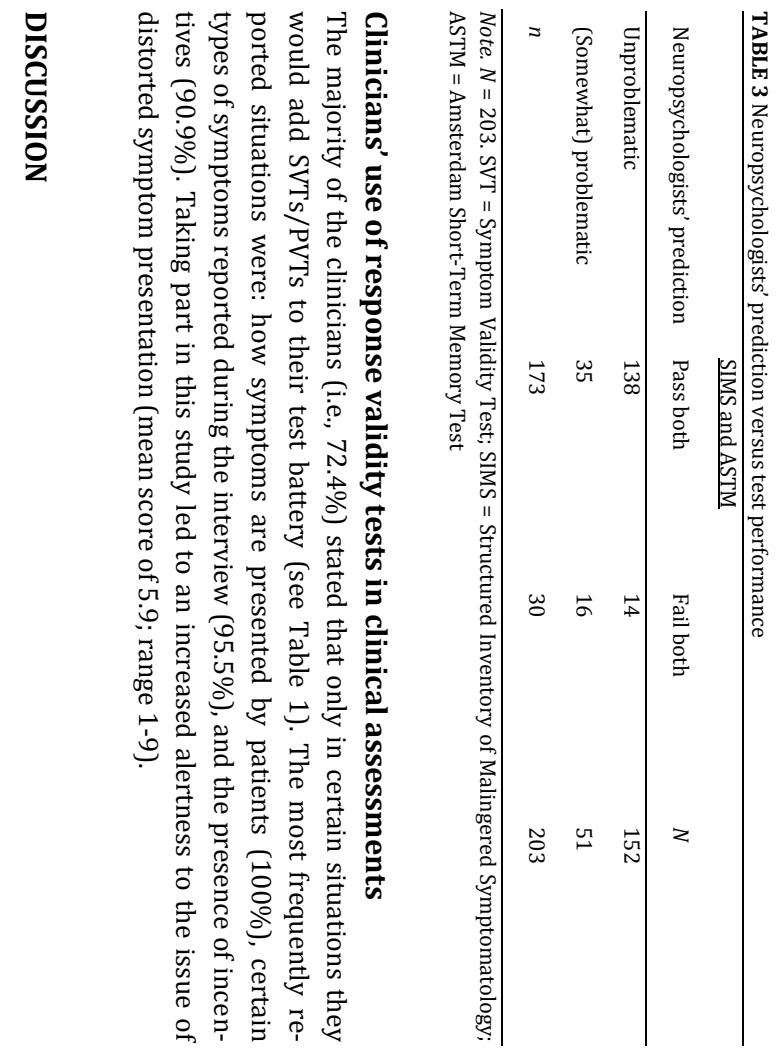

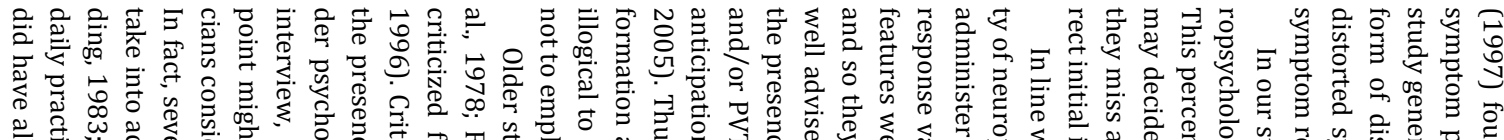

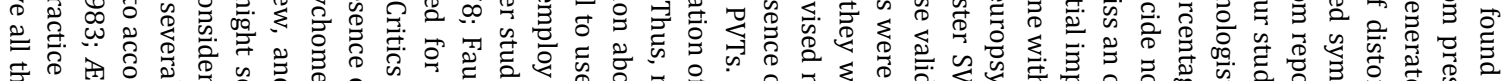

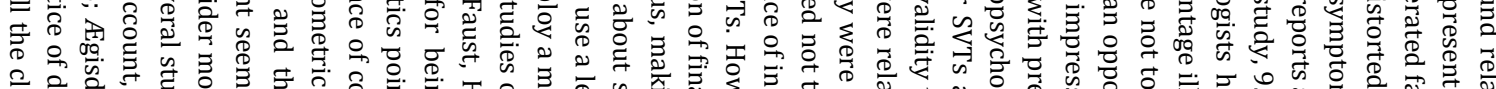

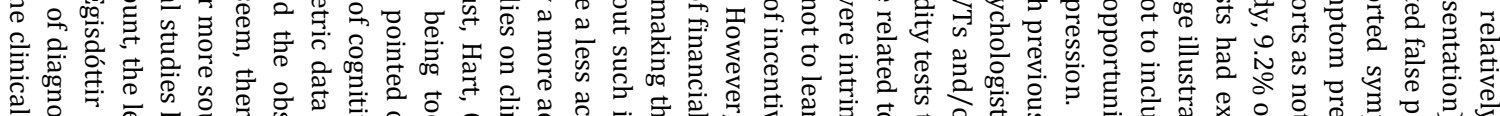

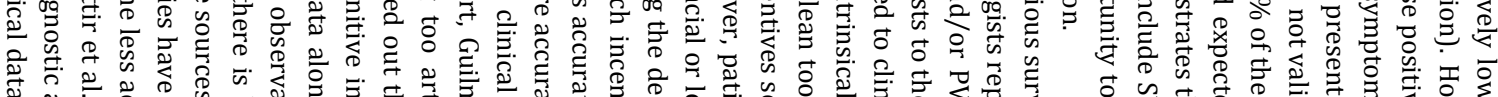

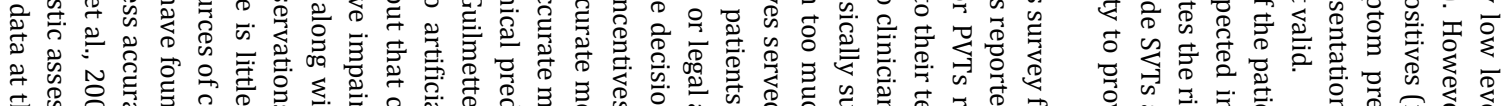

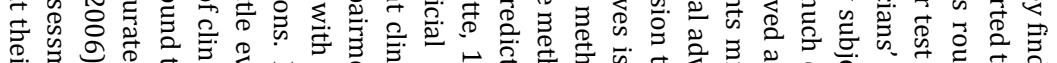

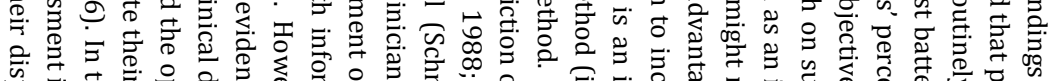

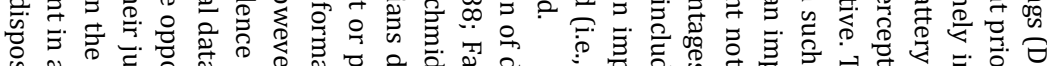

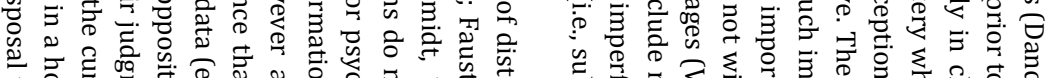

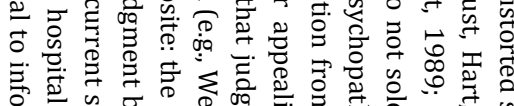

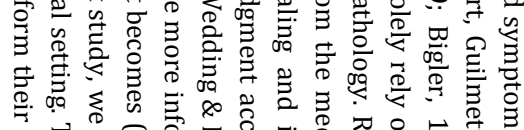

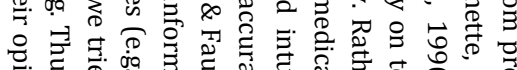

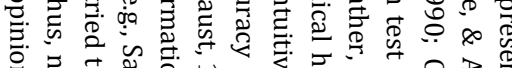

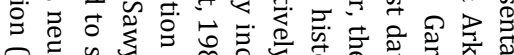

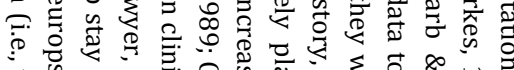

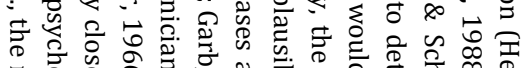

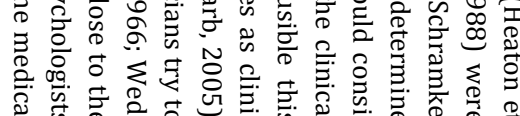

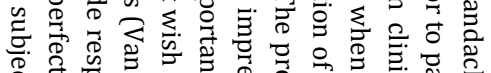

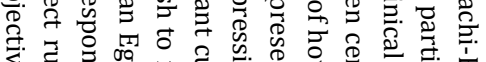

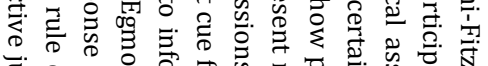

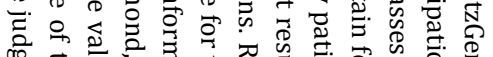

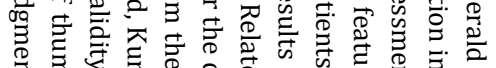

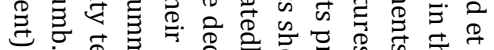

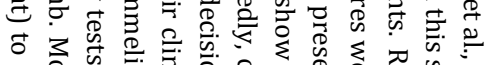

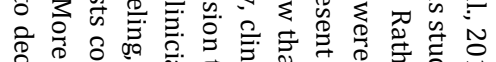

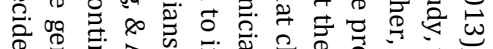

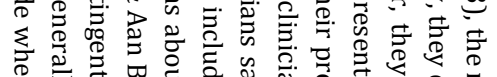

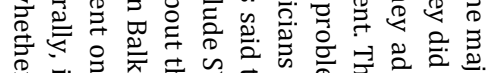

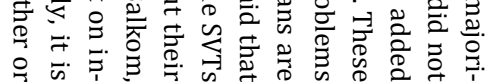

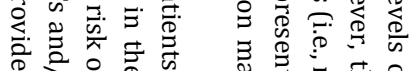

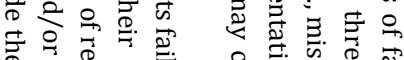

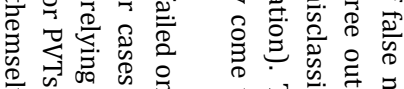

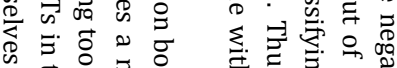
¿.

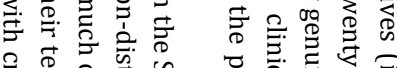

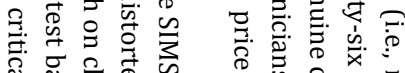

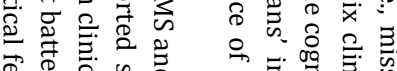

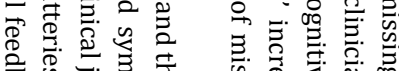

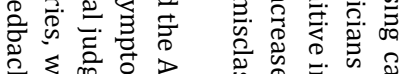

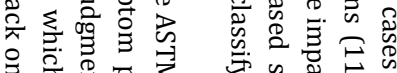

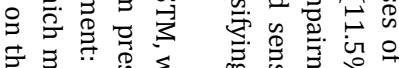

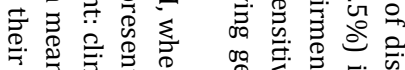

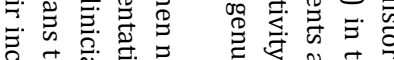

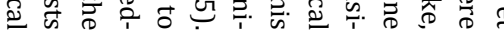




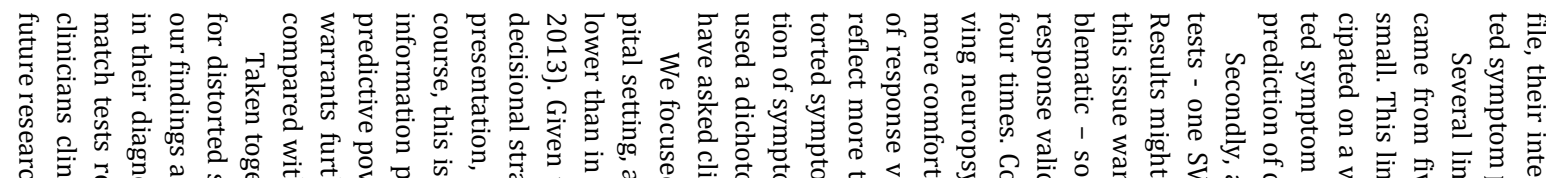

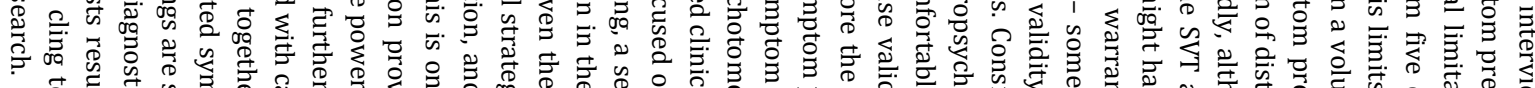

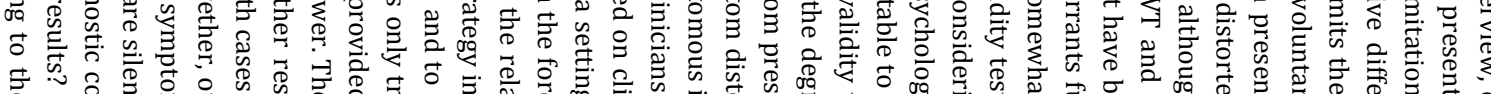

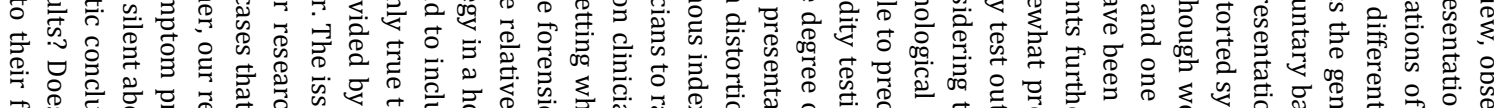

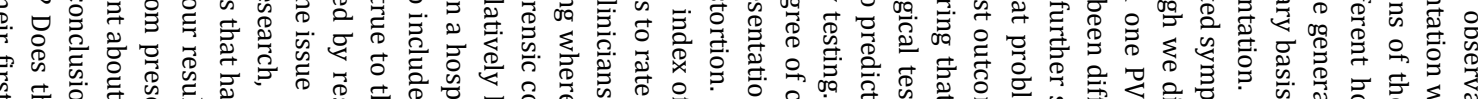

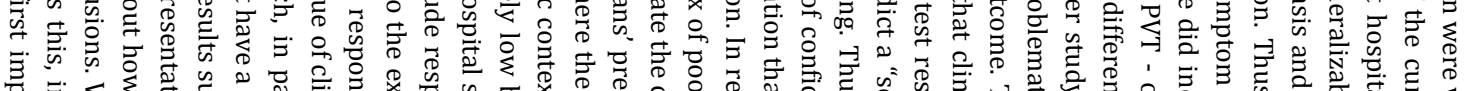

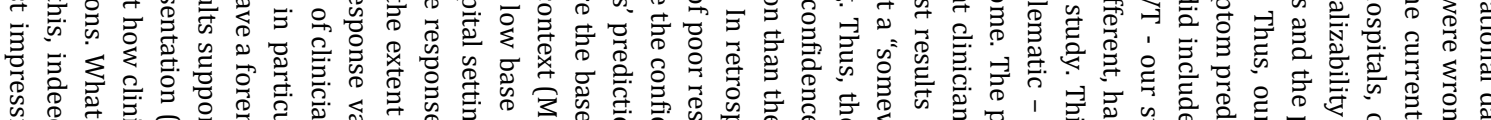

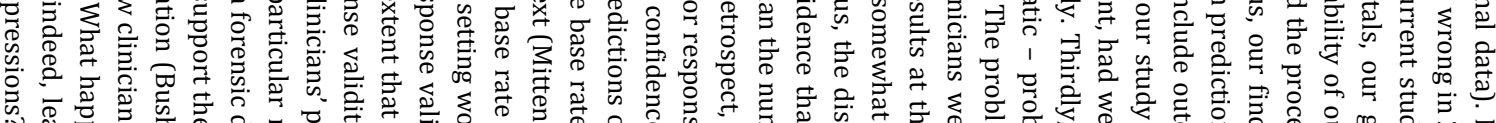

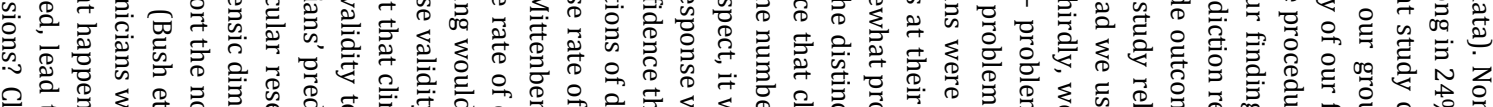

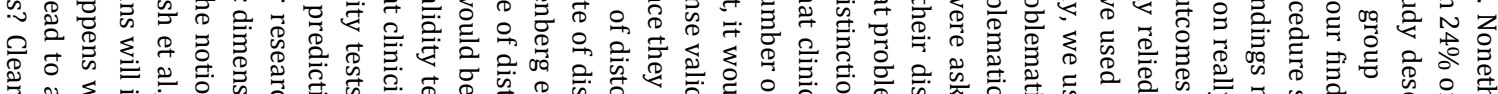

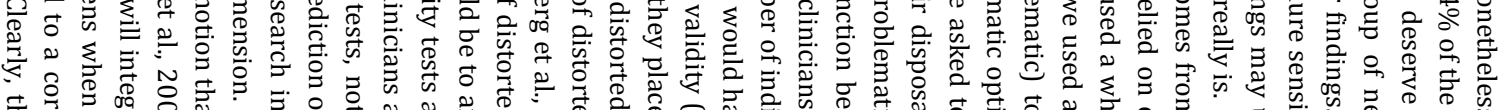

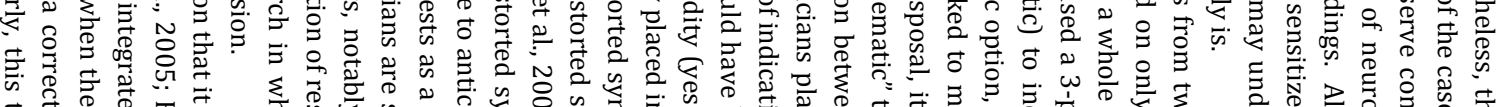

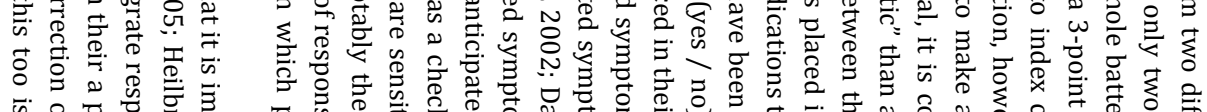

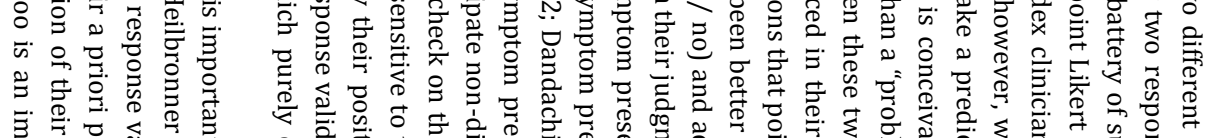

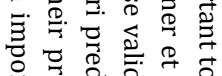

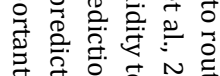

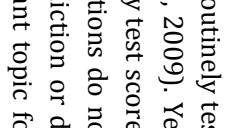

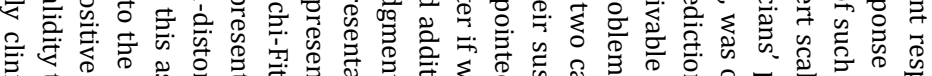

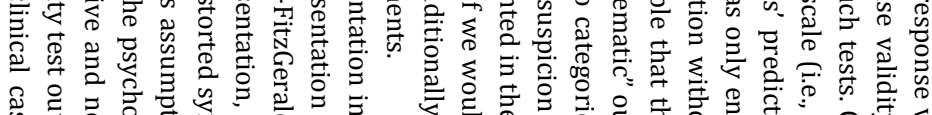

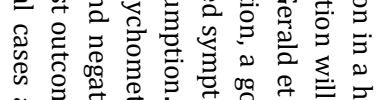

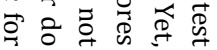

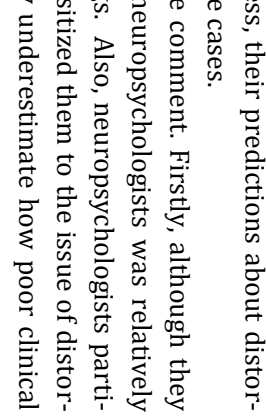

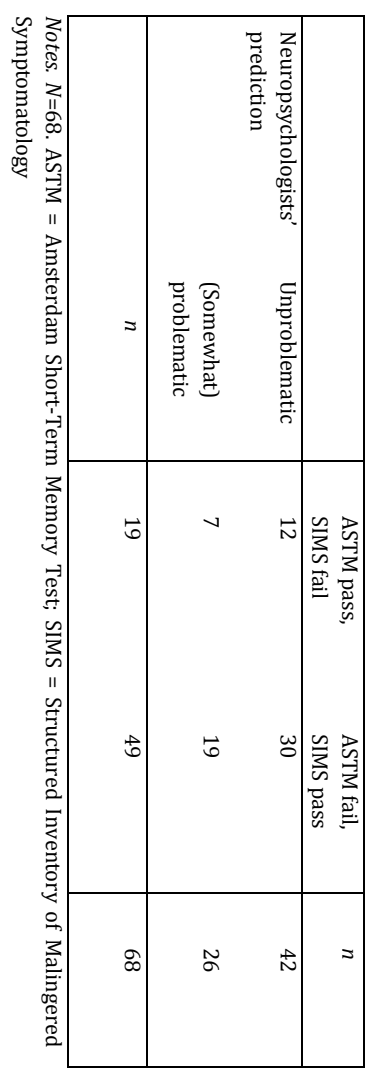



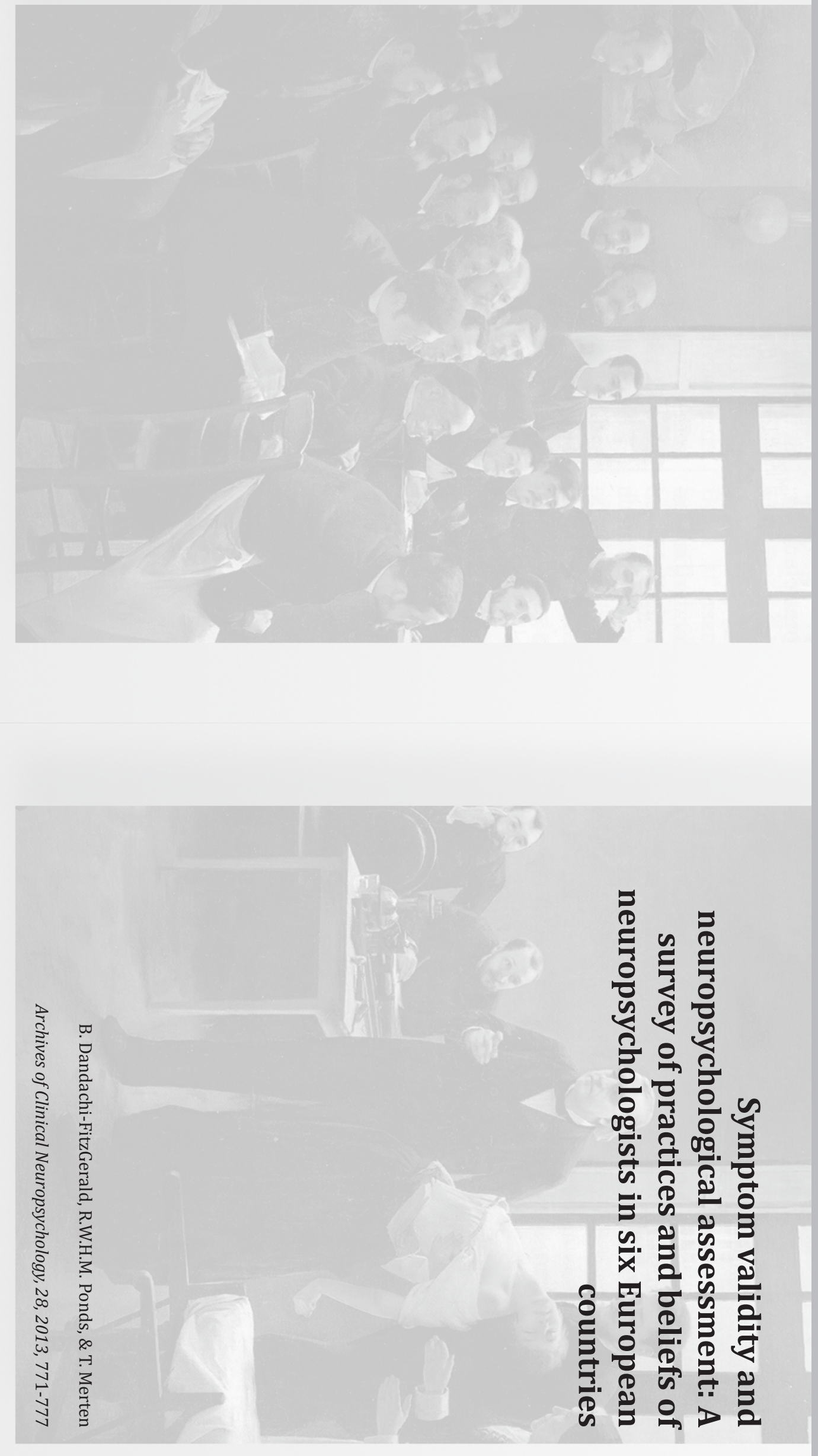

罚 


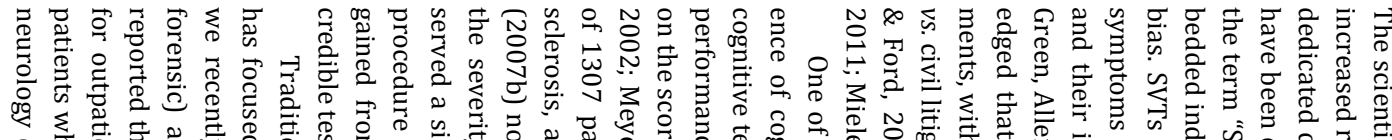
过

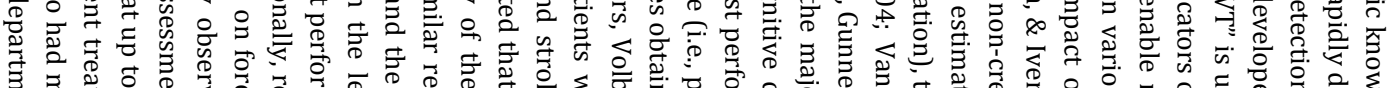

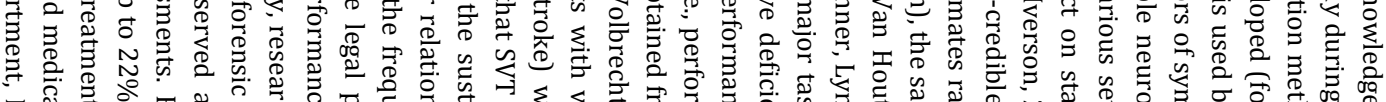
丆贝人

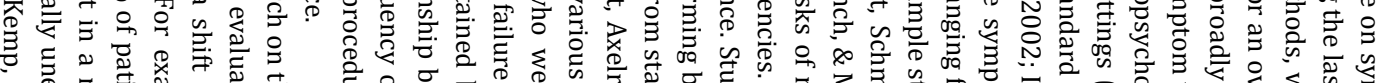

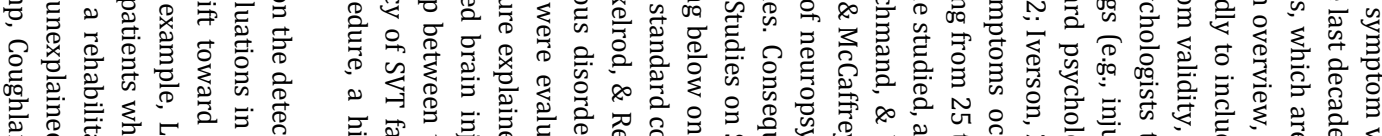

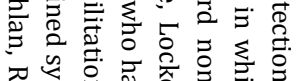

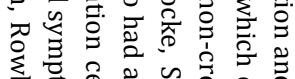

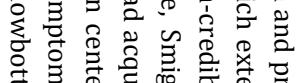

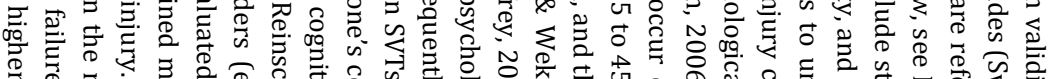
क्ञ

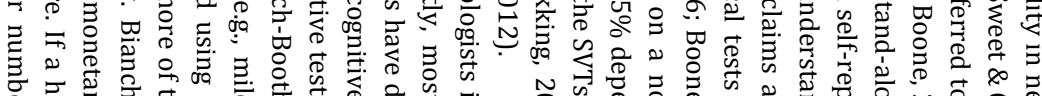
के

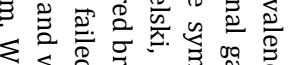

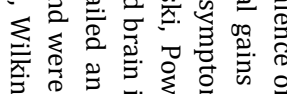

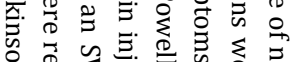

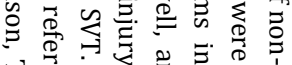

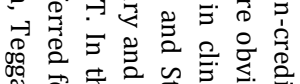

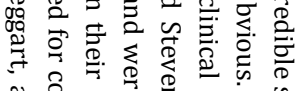

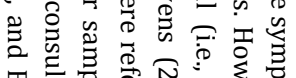

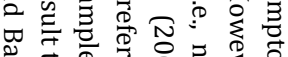

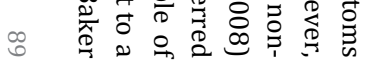

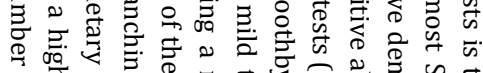

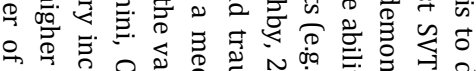

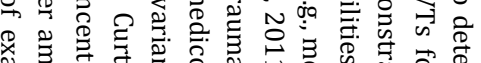

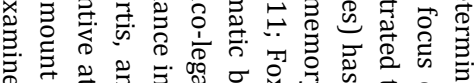

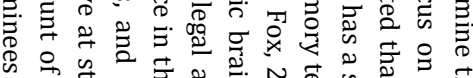

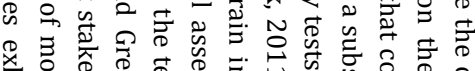

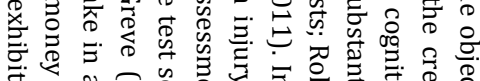

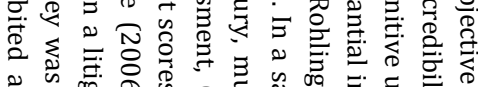
थ के

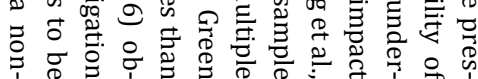

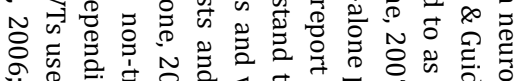

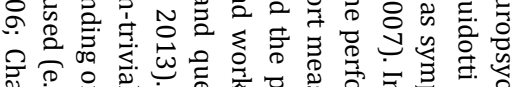

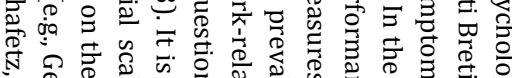

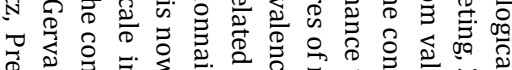

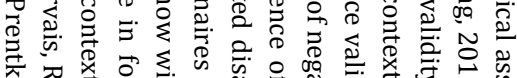

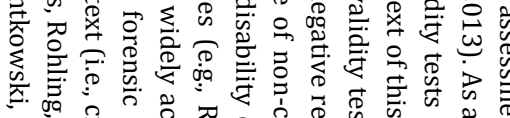

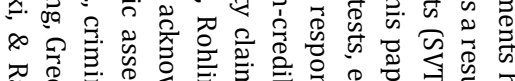

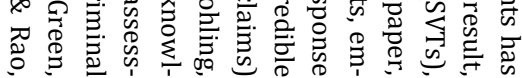




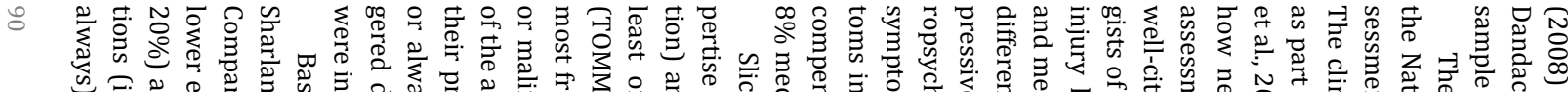

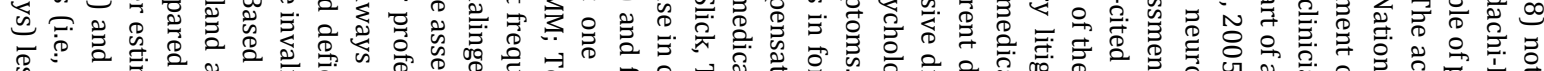

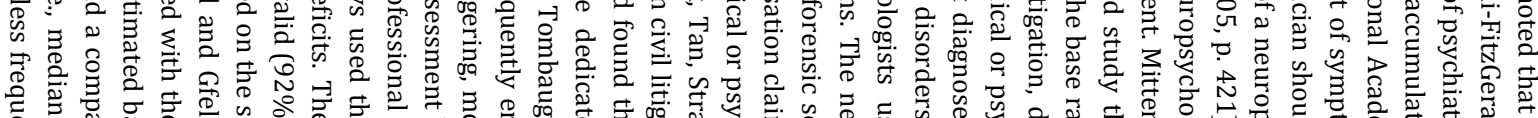

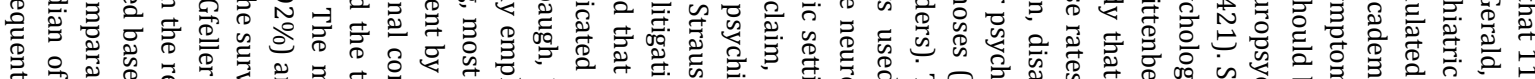

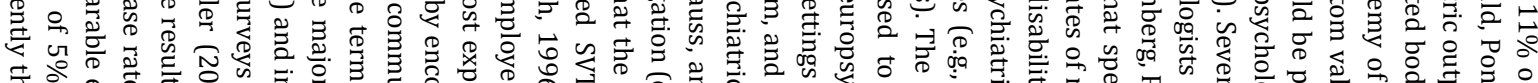

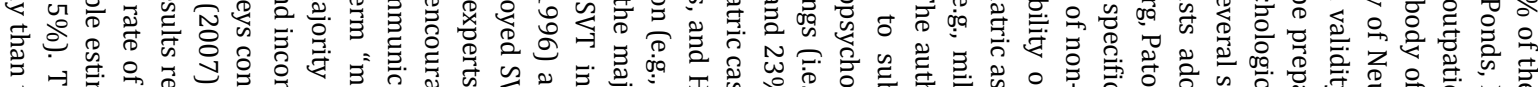

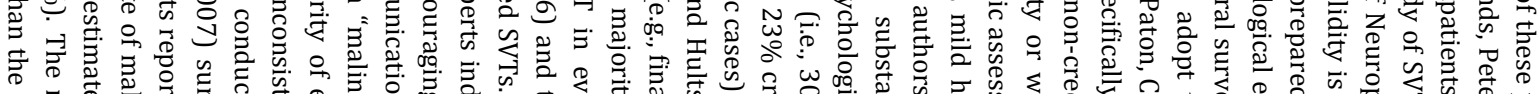

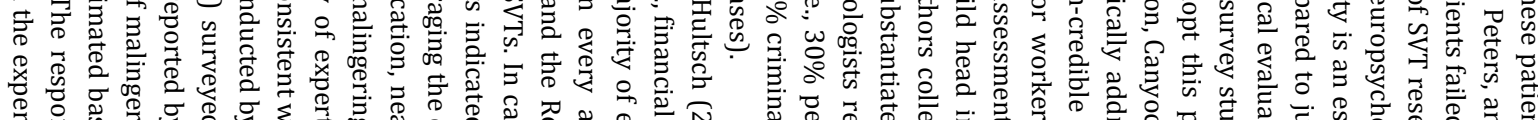

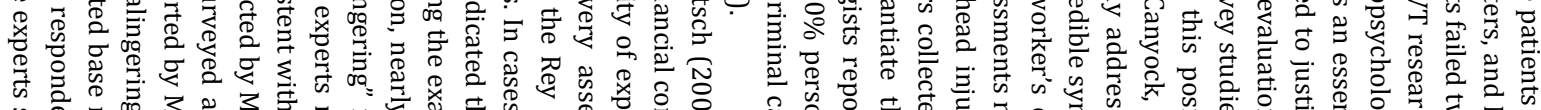

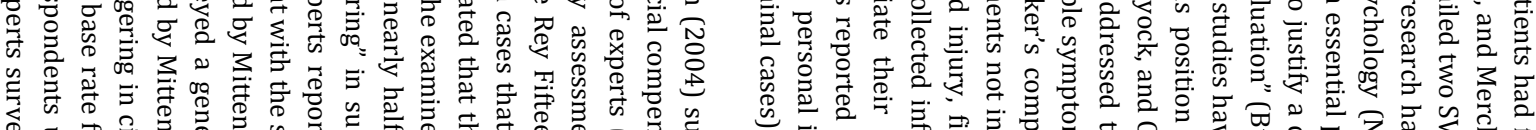

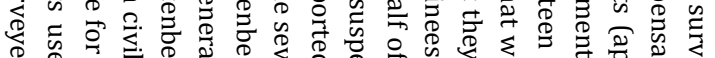

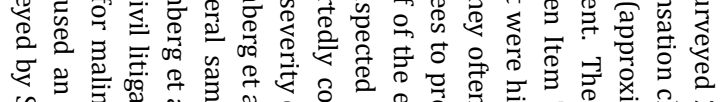

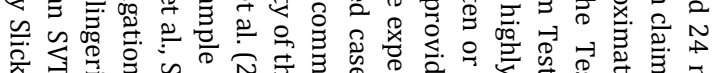

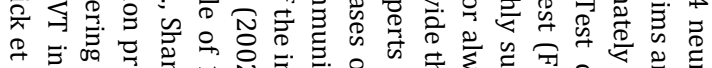

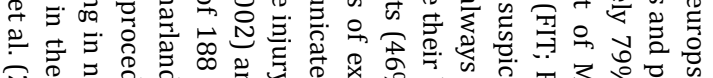

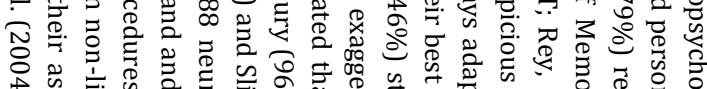

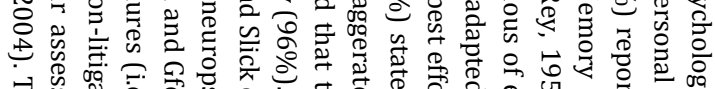

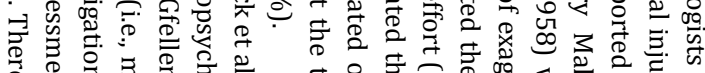

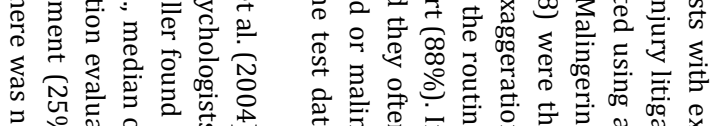

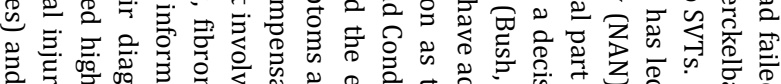

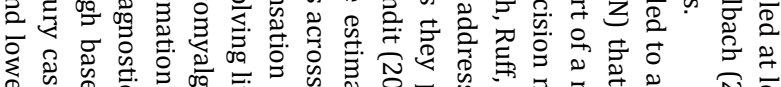

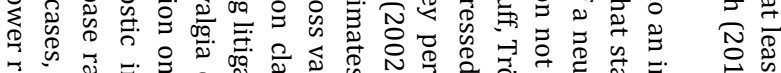

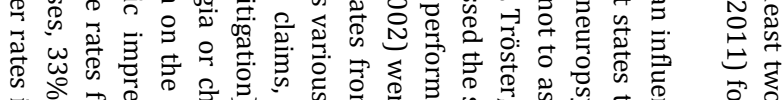

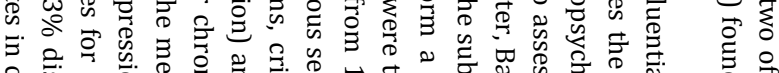

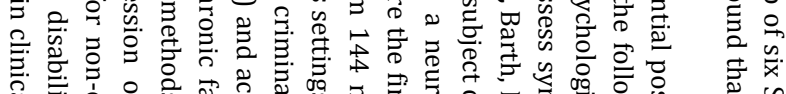

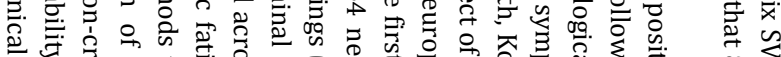

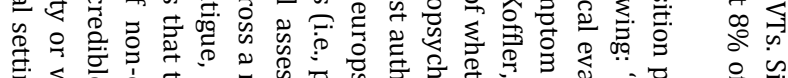

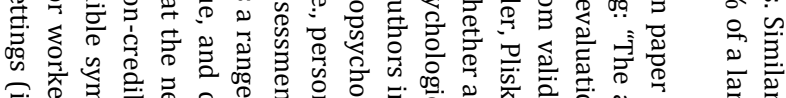

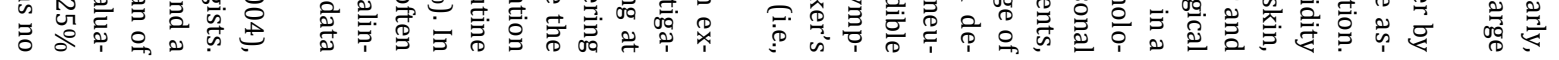

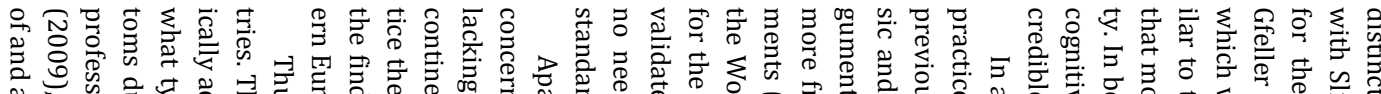
ơ

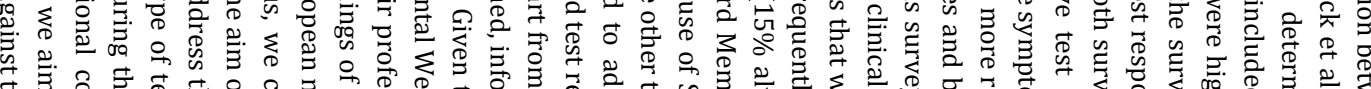

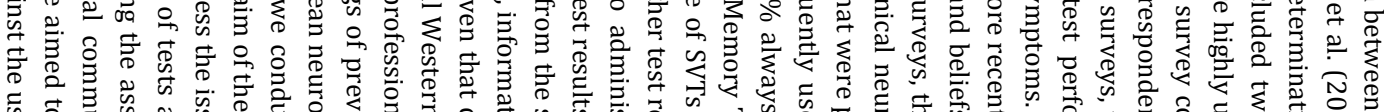

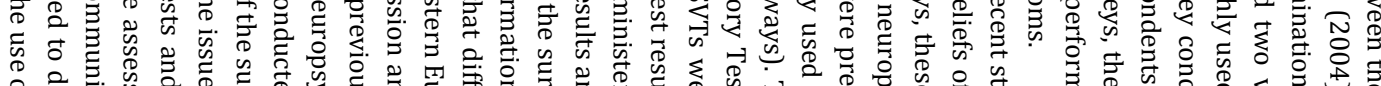

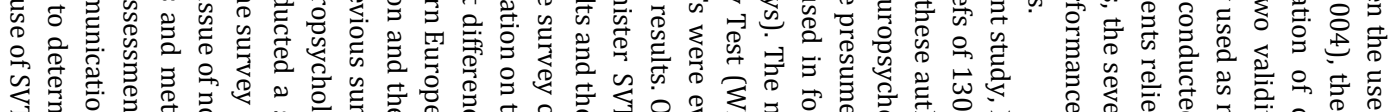

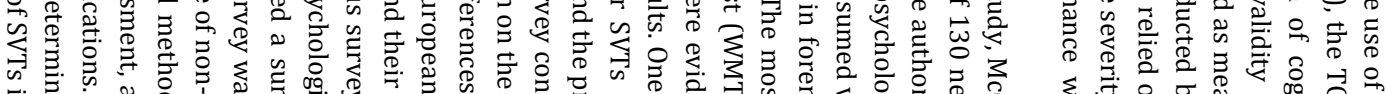

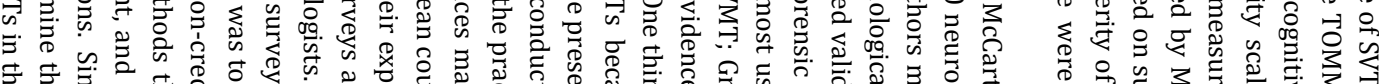

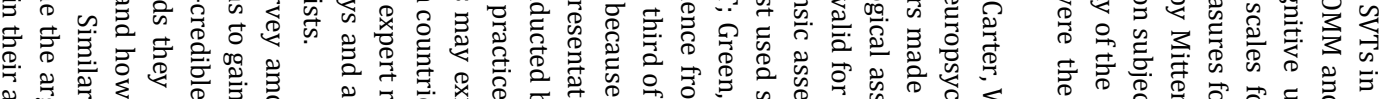

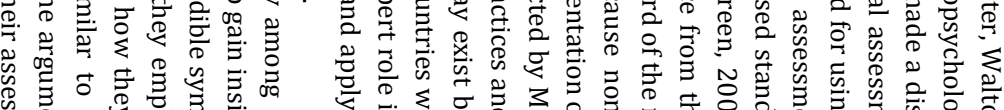

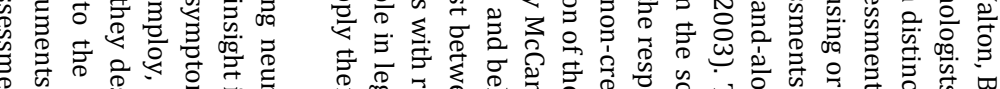

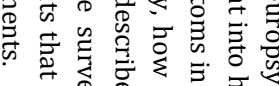
ॠ

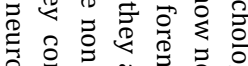

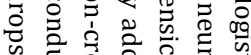

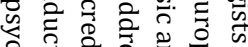

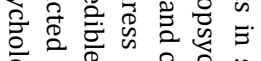
ণ वृ

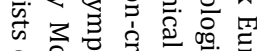

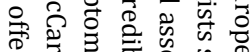

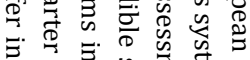

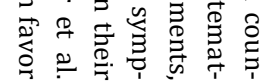

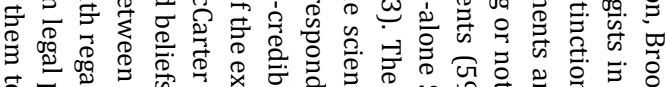

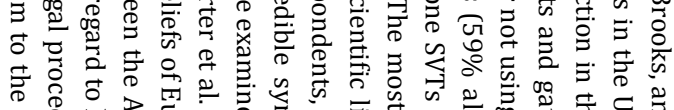

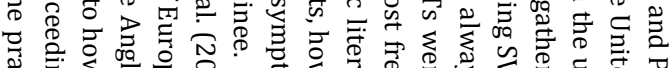

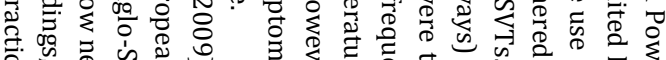
त. ब0

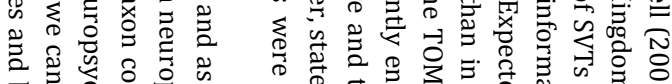
员

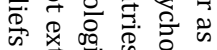

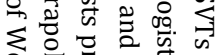

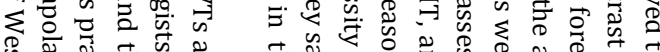

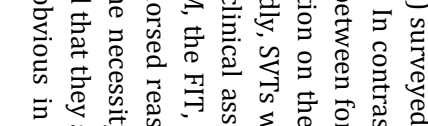

क 응 $\frac{1}{0} 0$

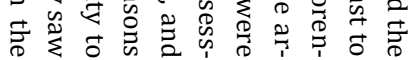

न

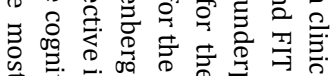

$\rightarrow$ 过

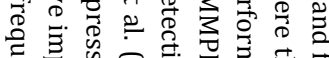

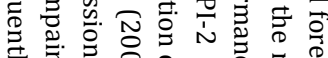

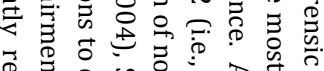

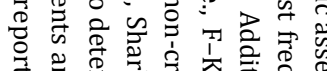

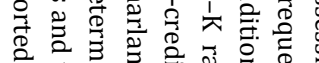

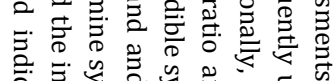

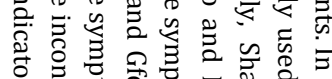

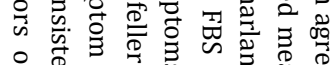
की

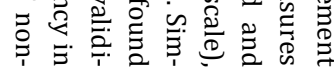




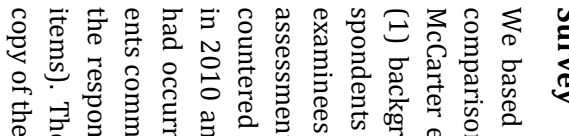
a then

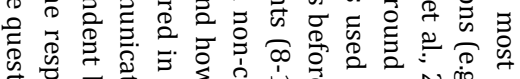

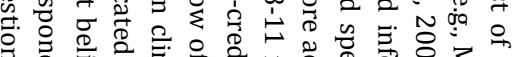

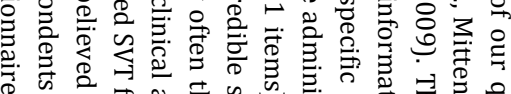

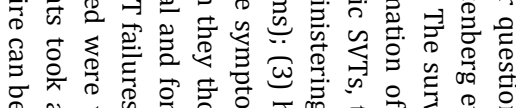

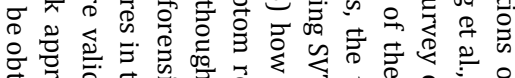

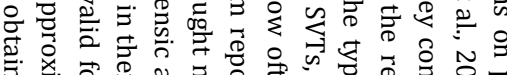

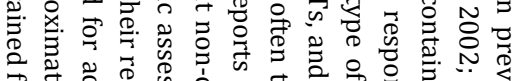

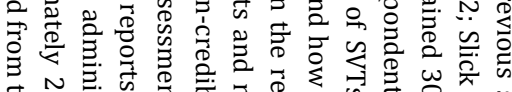

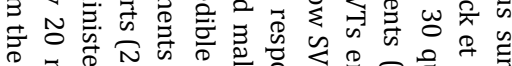

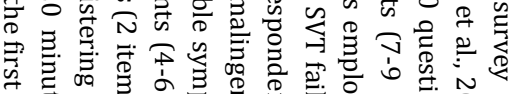

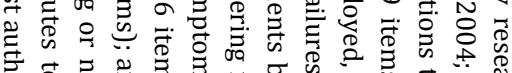

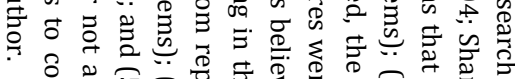

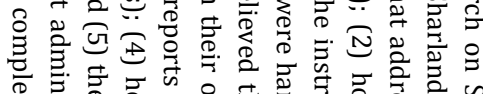

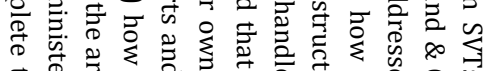

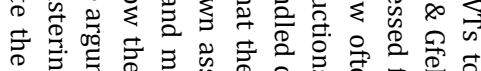

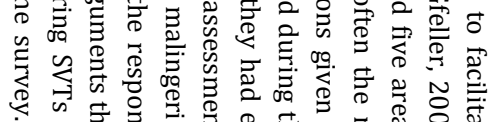

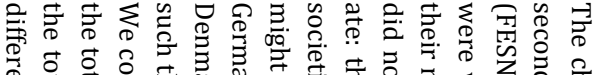

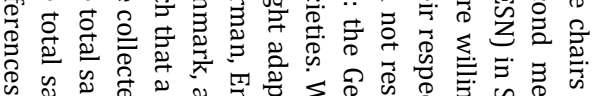

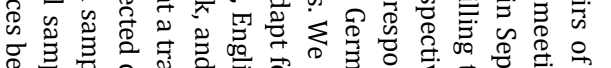

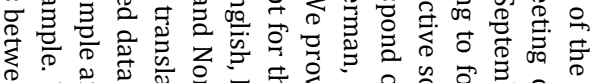

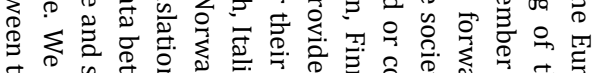

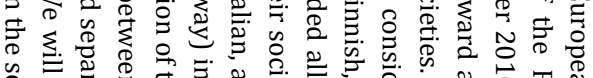

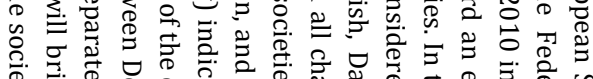

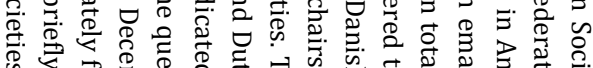

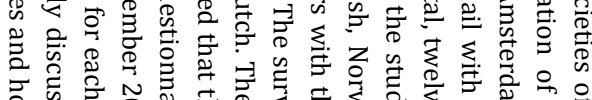
ठ

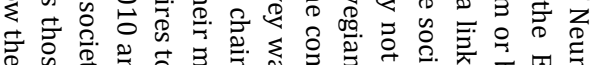

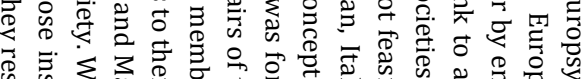

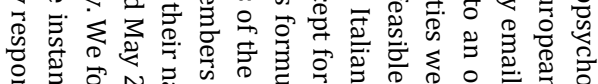

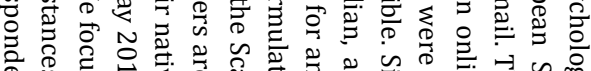

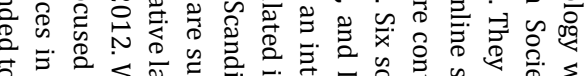

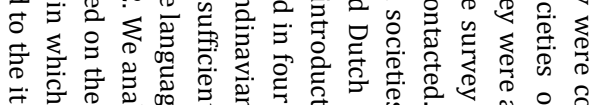

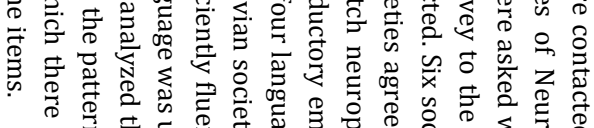

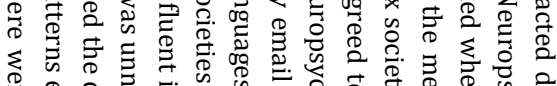

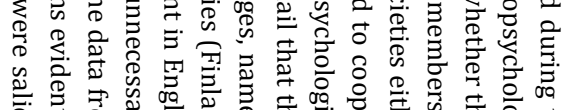

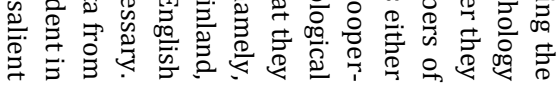

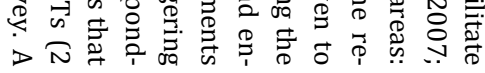
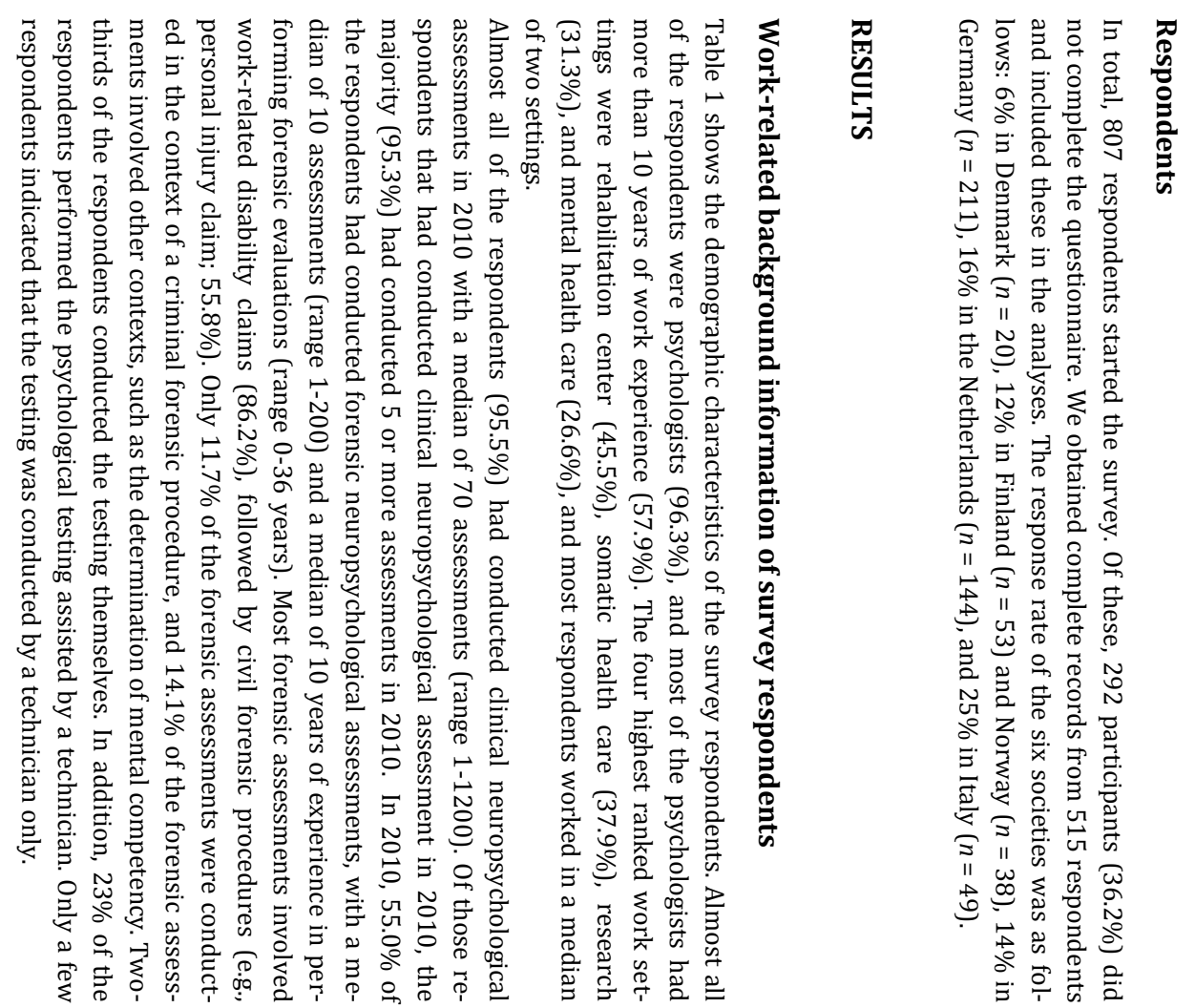


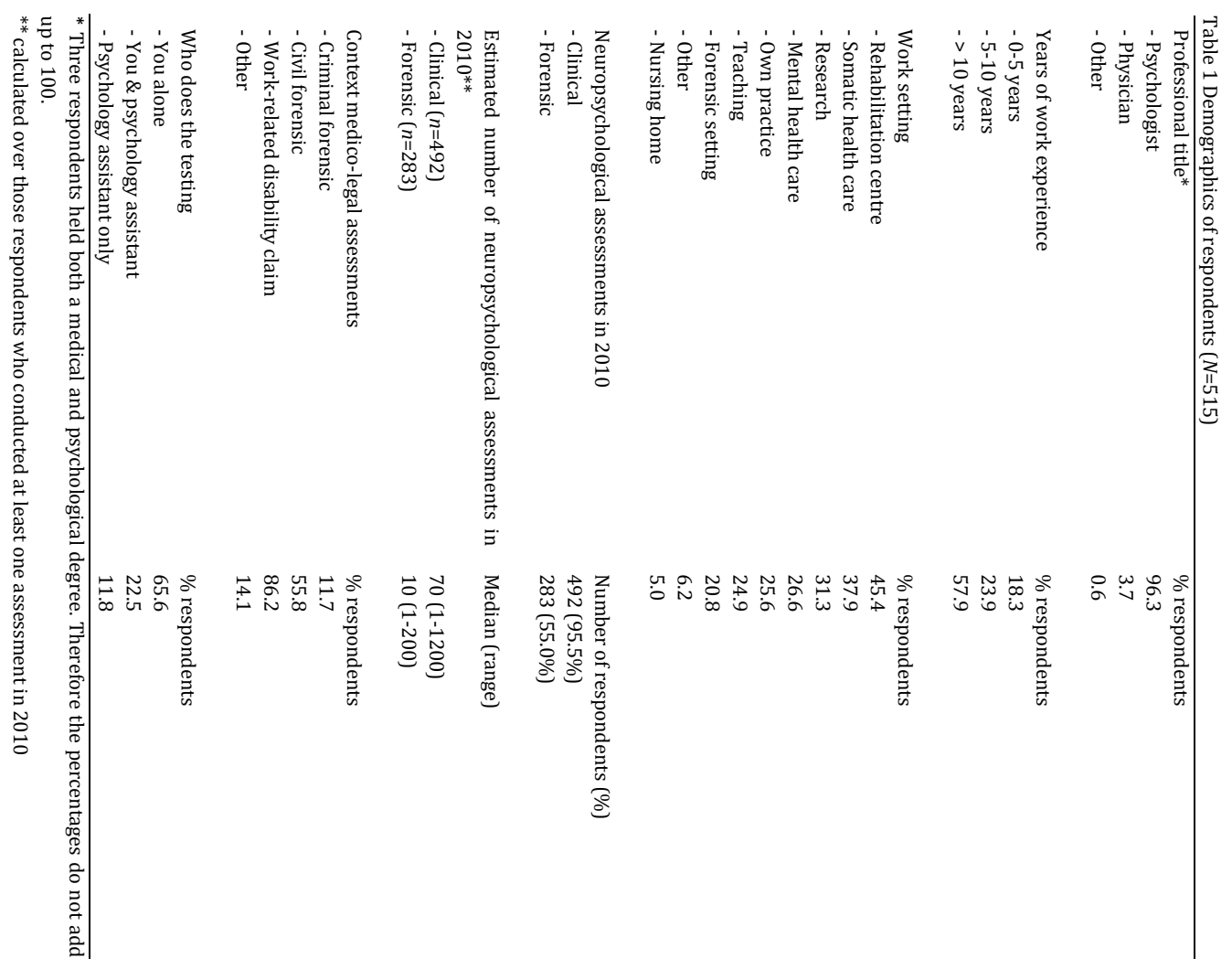

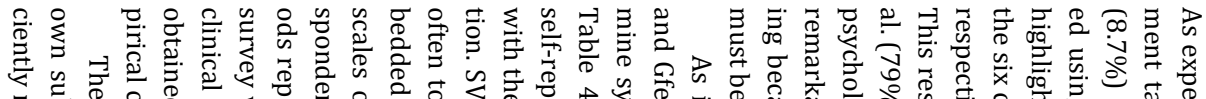

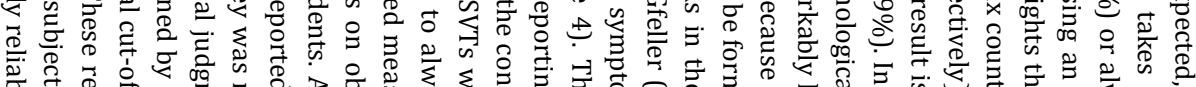

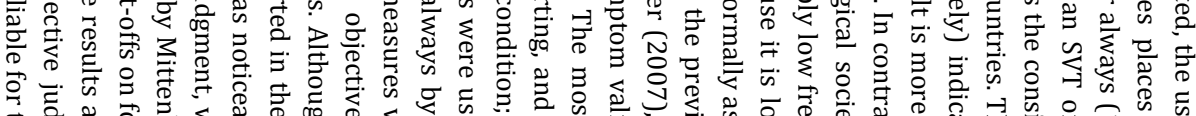

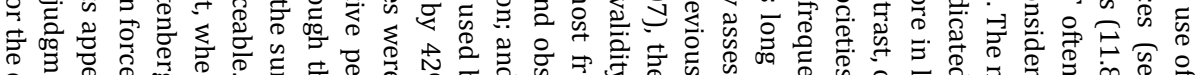

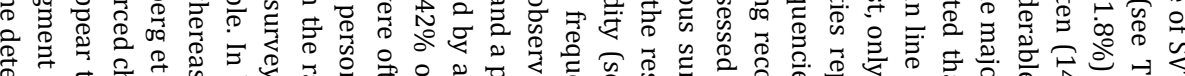

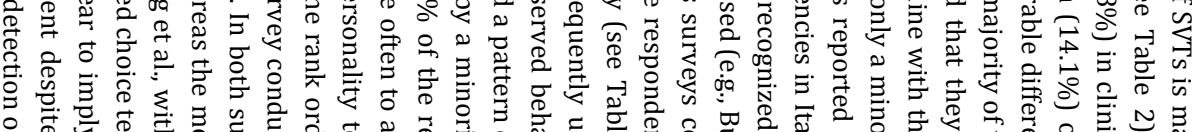

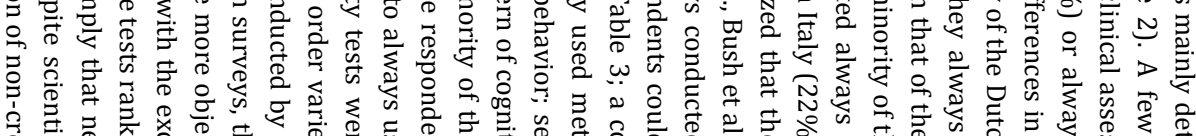

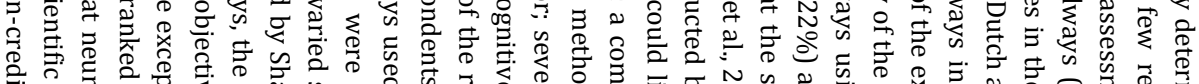

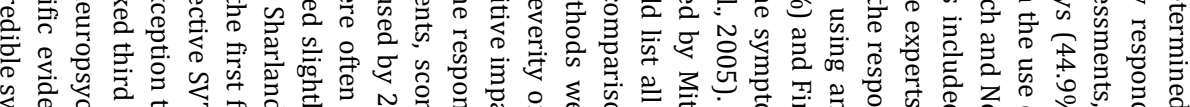

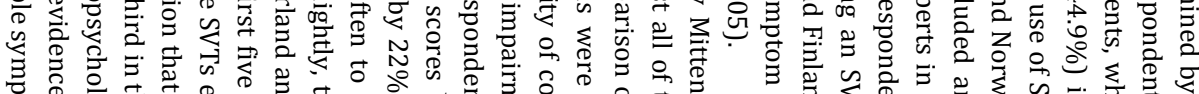

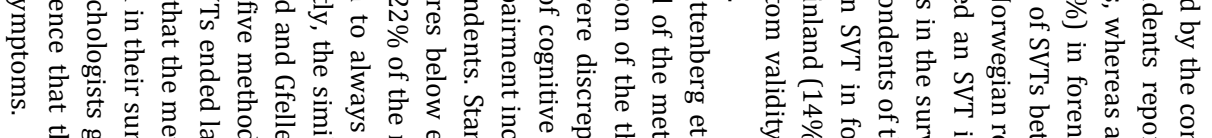

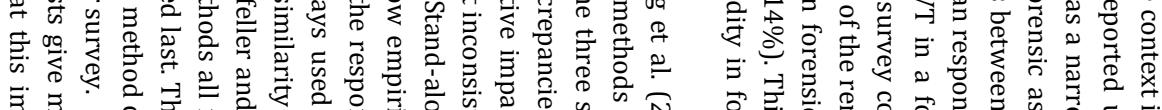

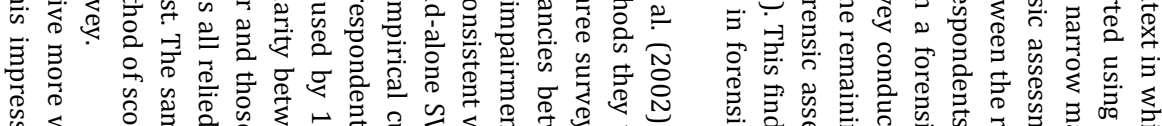

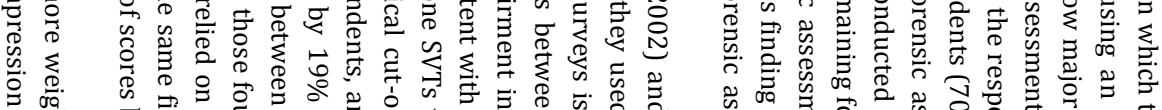

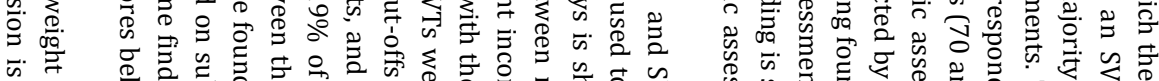

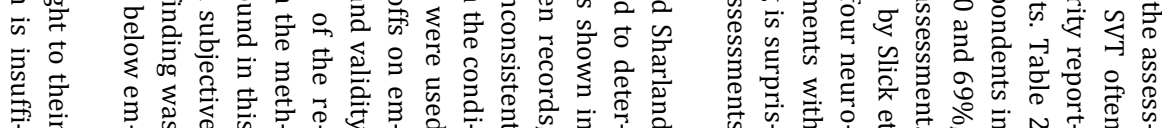

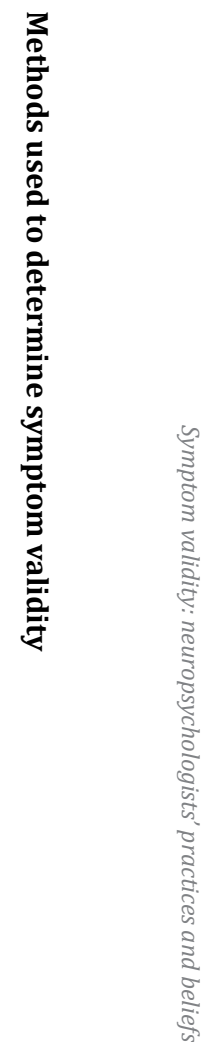




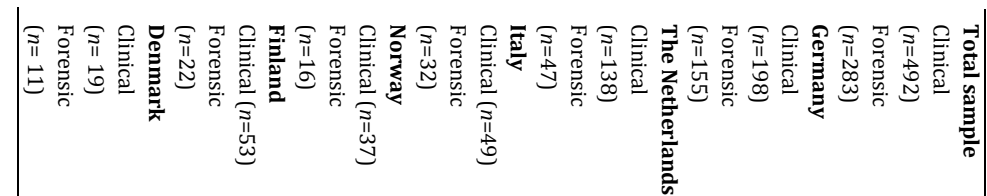

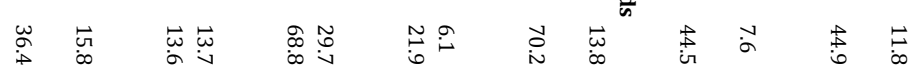

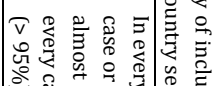

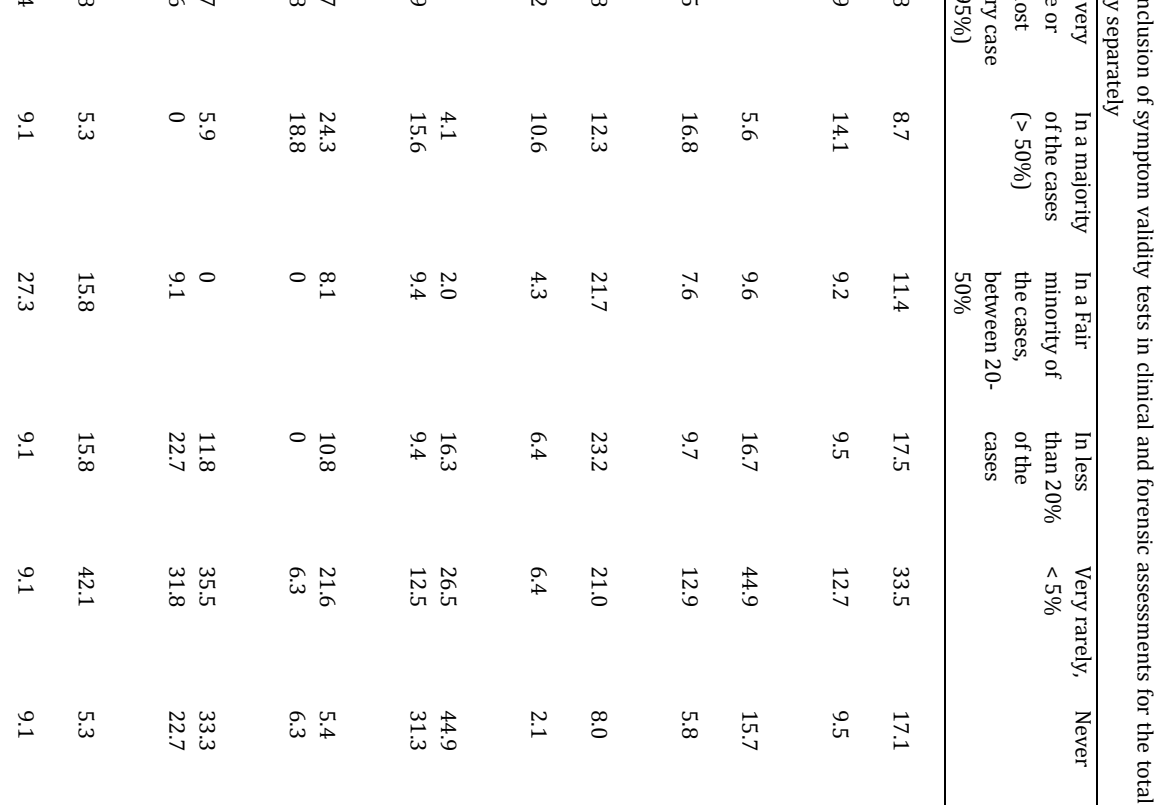
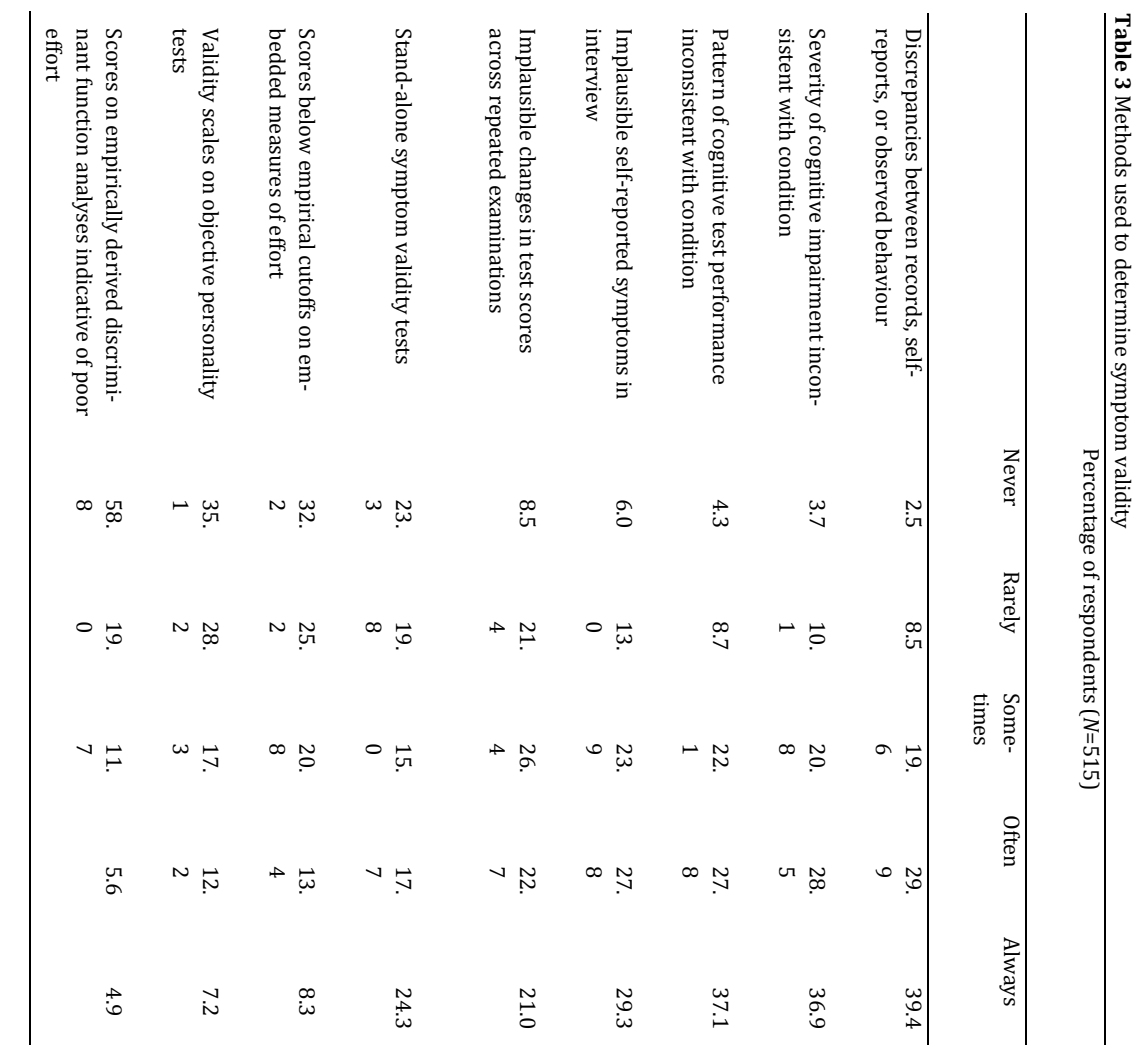

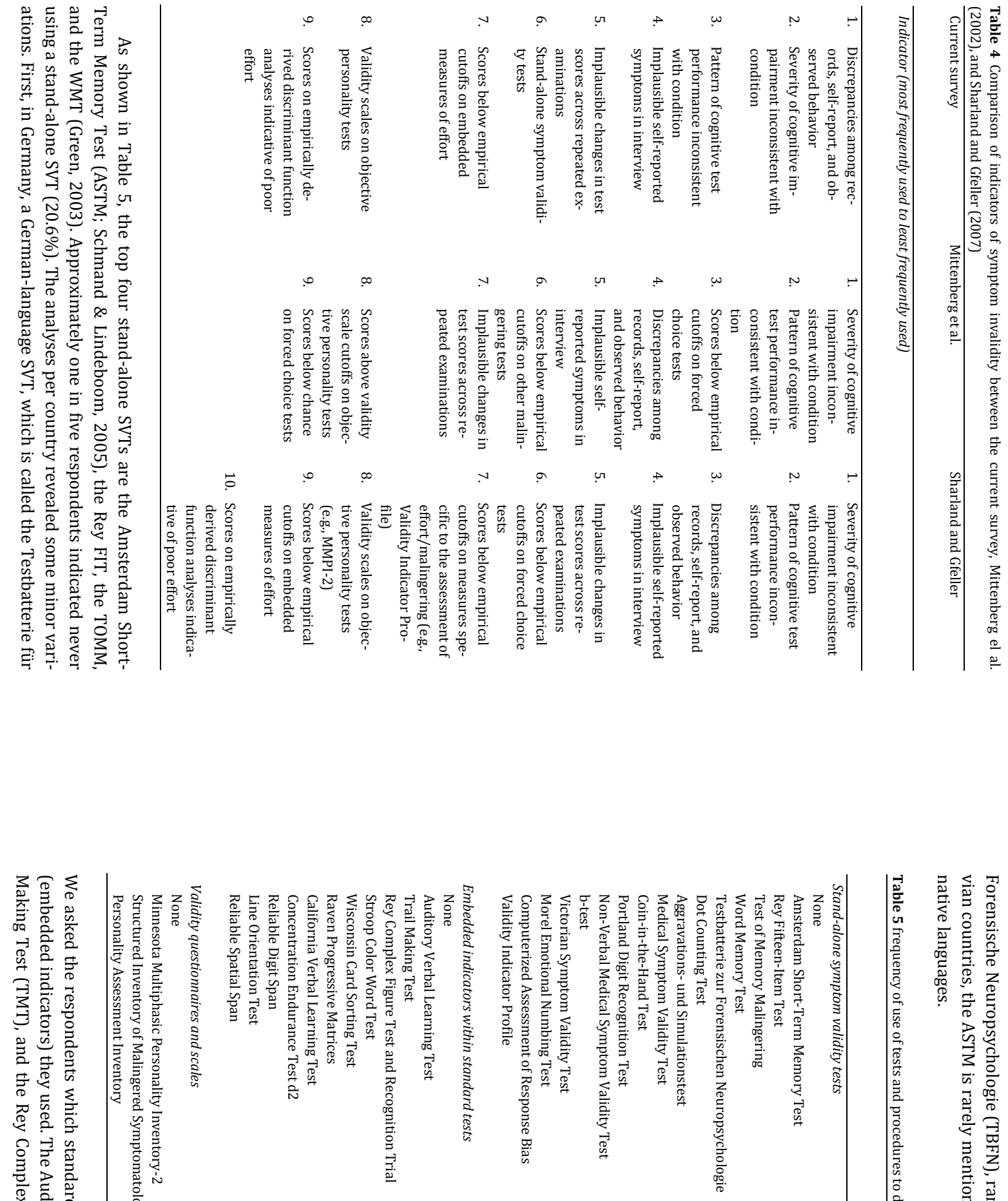

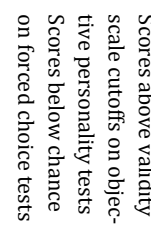
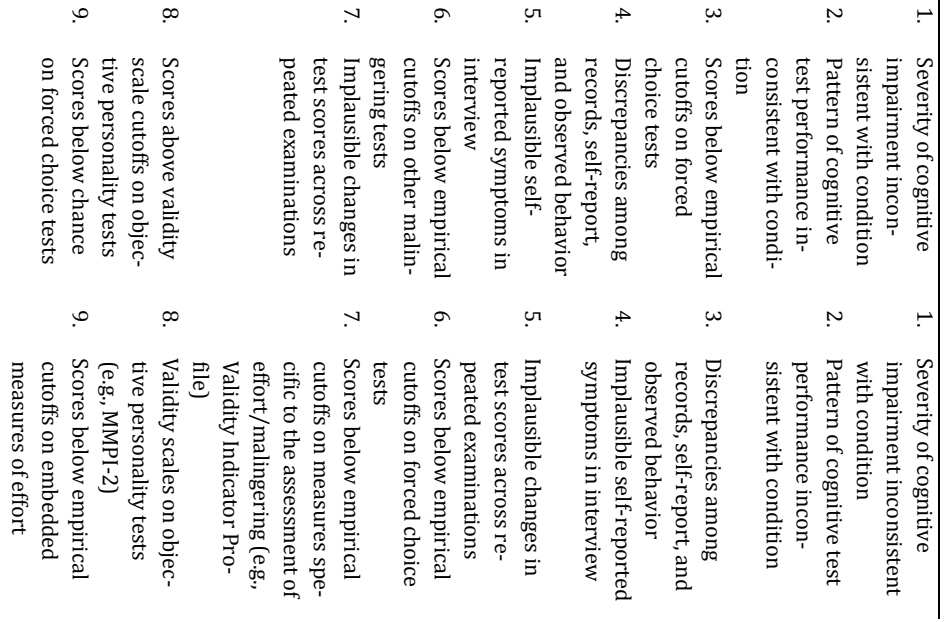

, 

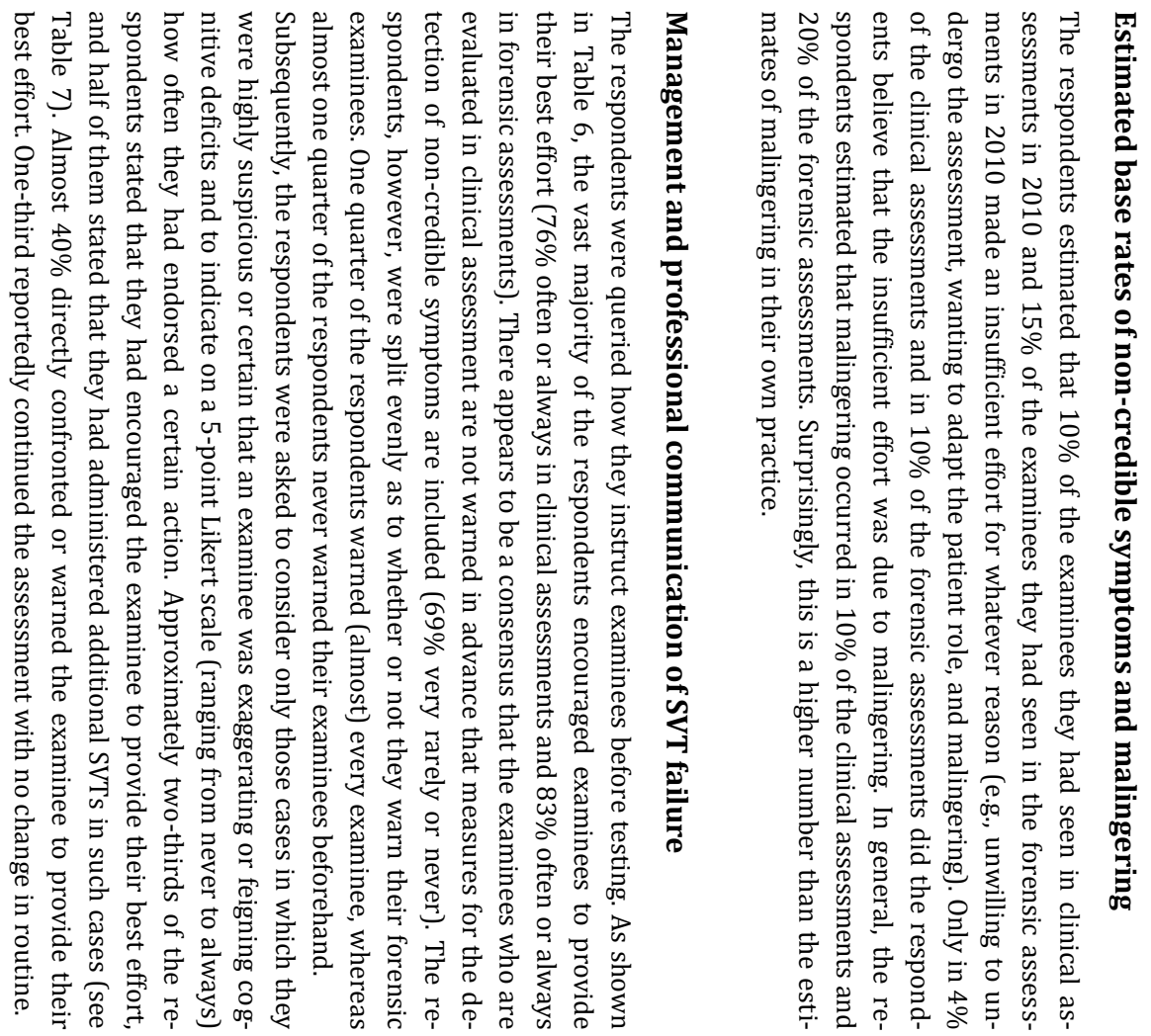

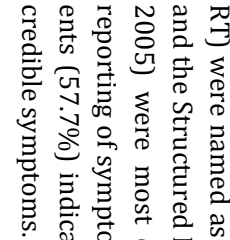

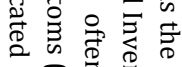

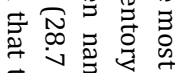

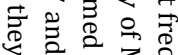

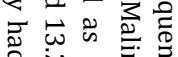

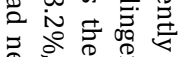

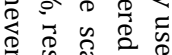

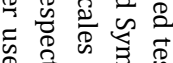

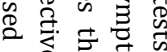

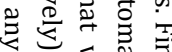

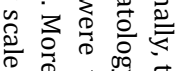

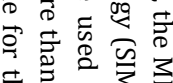

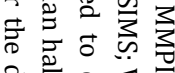
के के क्ष

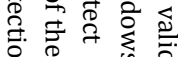

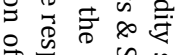

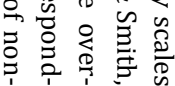

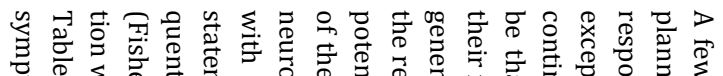

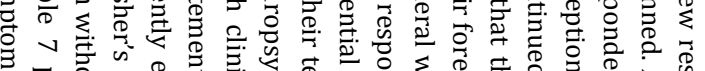

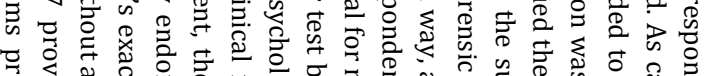

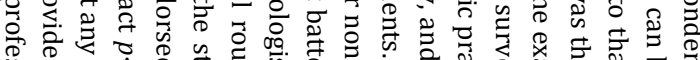

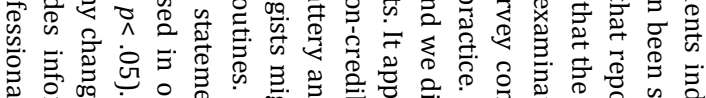

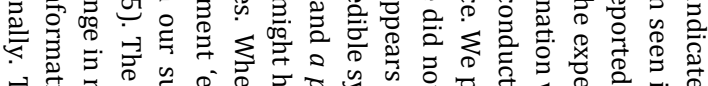

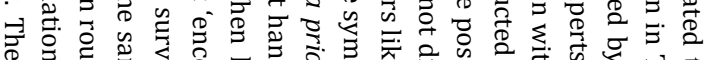

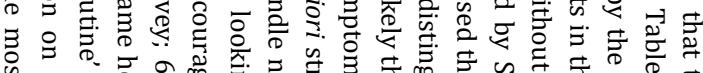

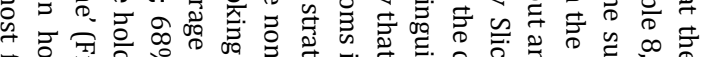

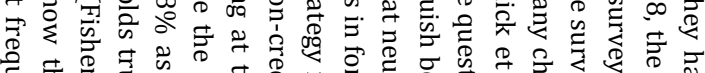

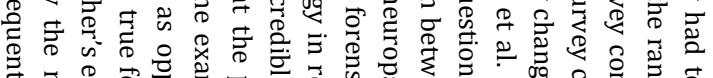

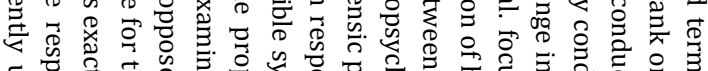

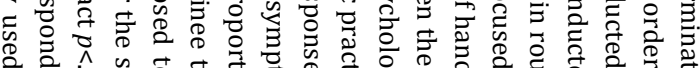

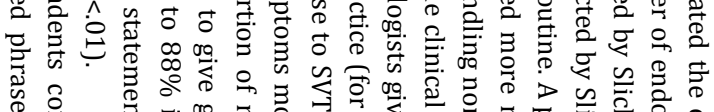
¿

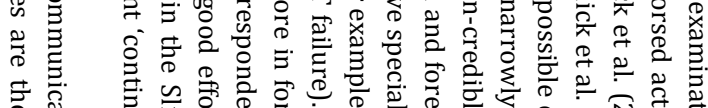

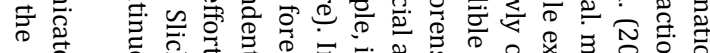

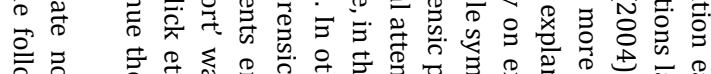

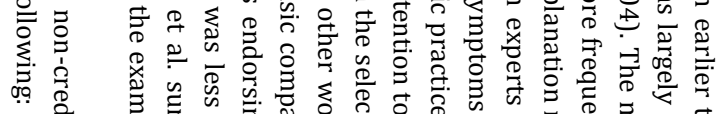

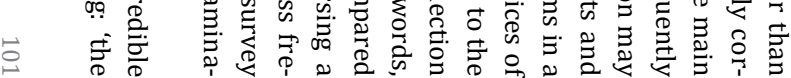

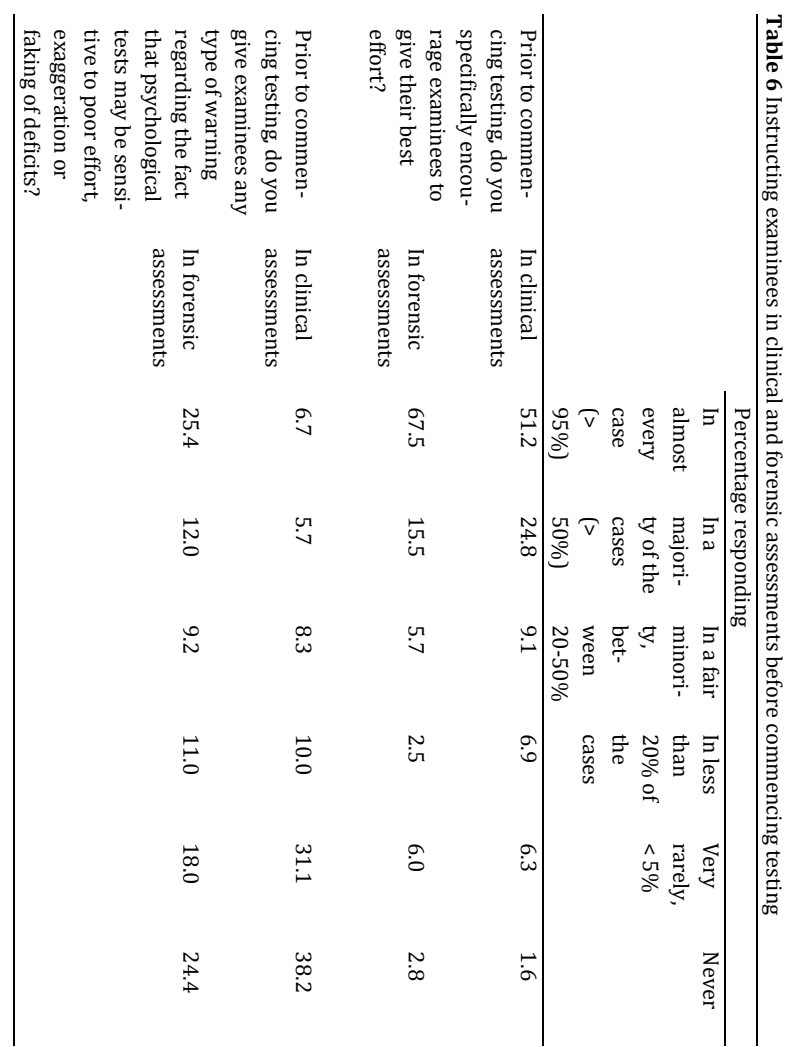




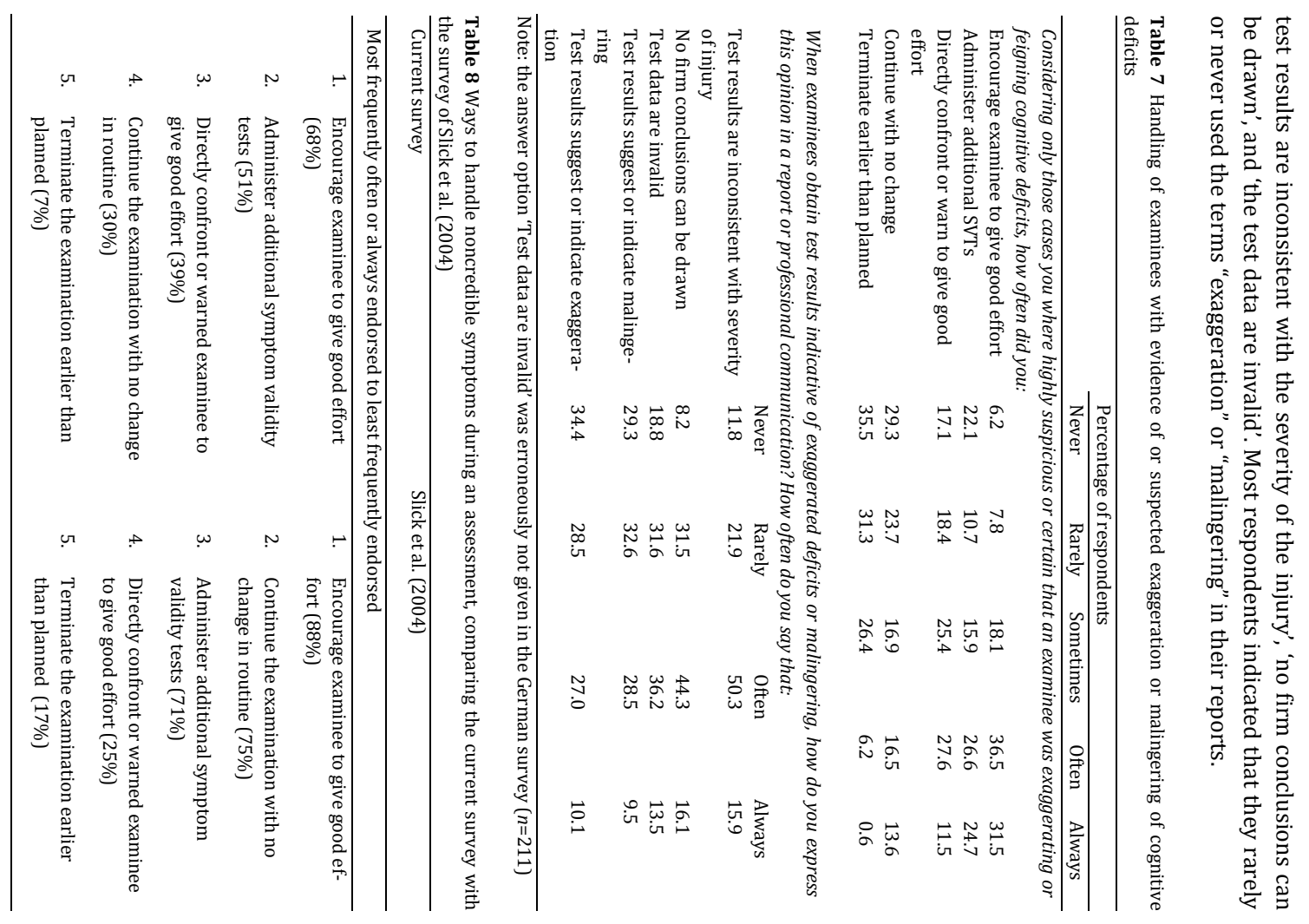

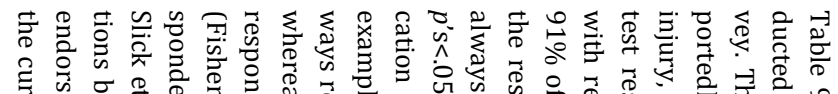

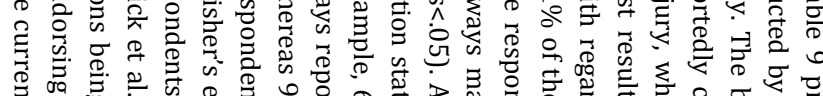
等

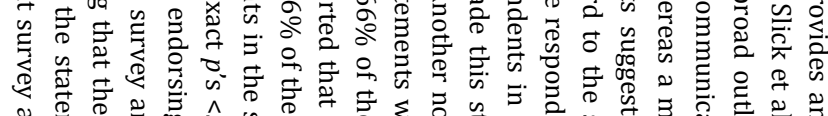

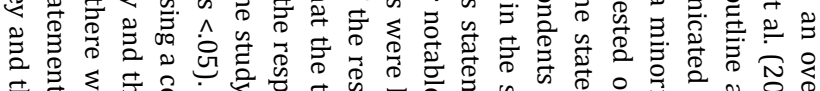

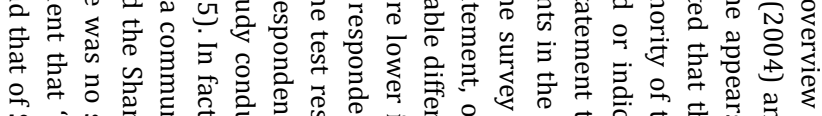

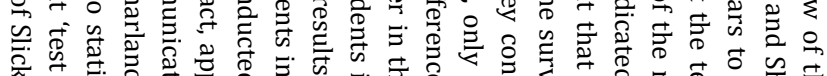

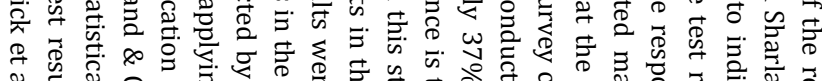

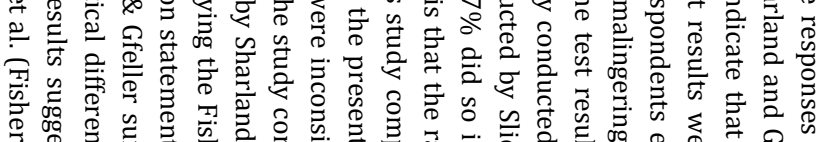

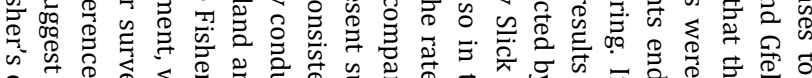

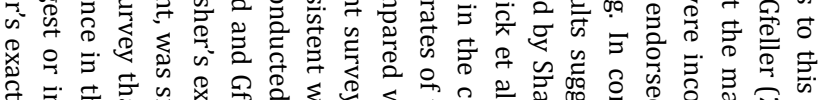

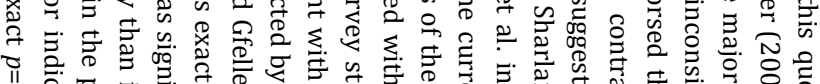

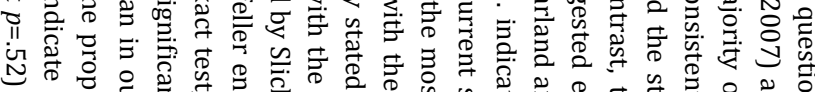

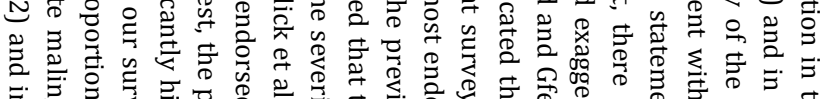

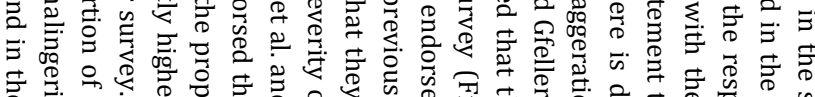

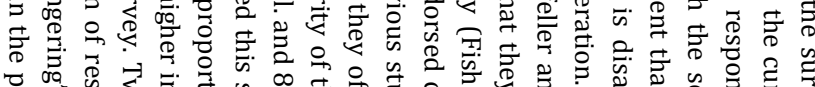

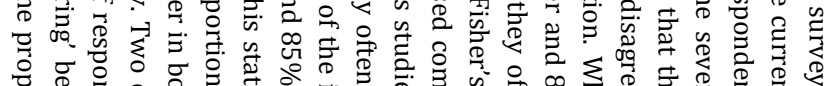

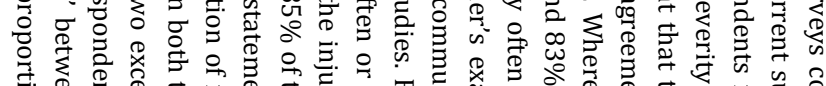

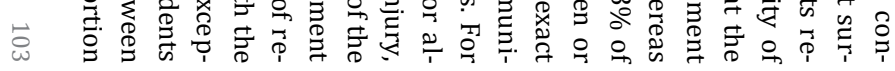
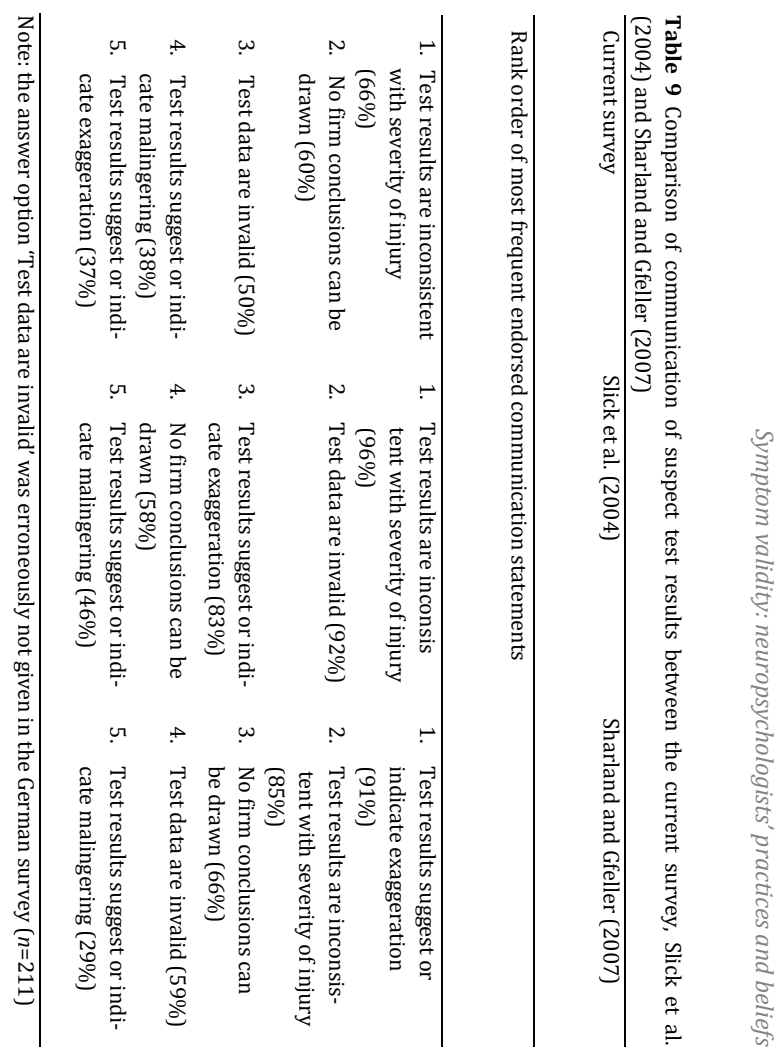


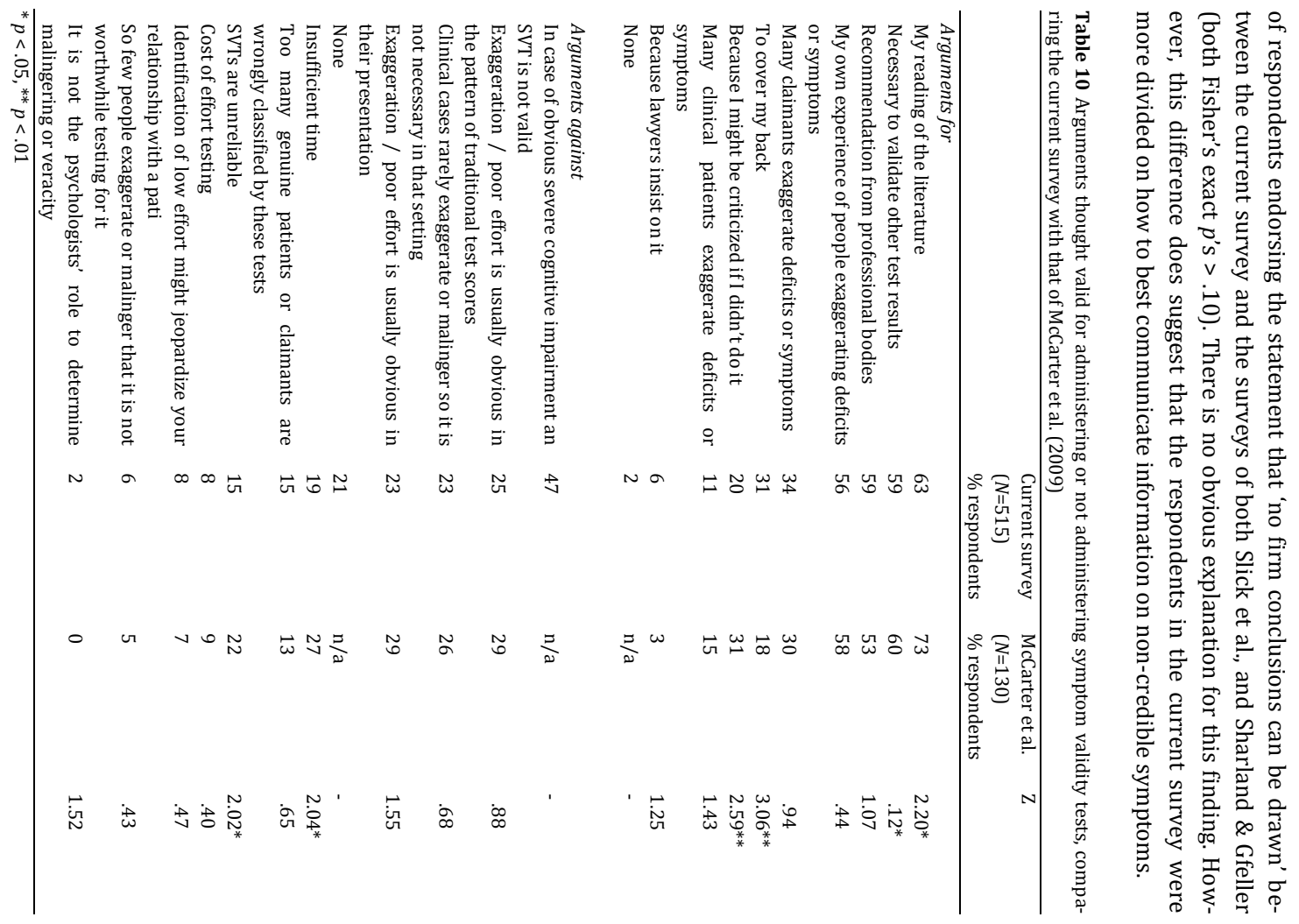

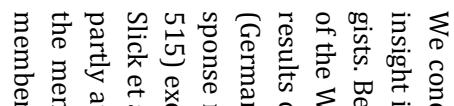

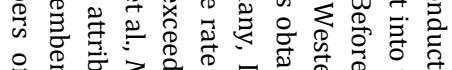

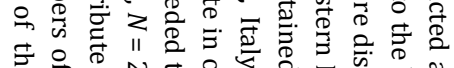

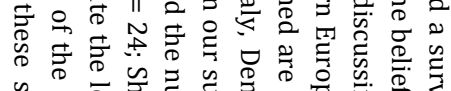

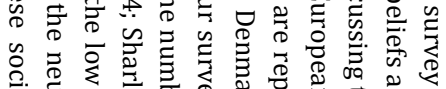
‥

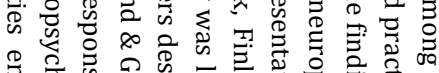

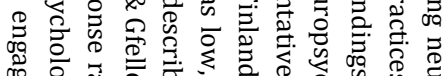

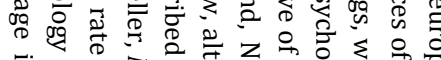
$\Xi$ 品

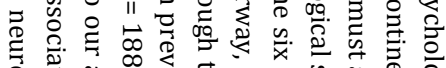

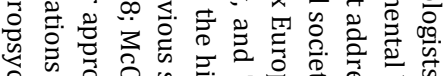

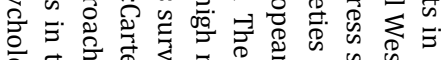

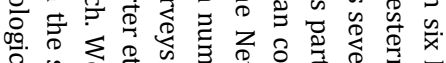

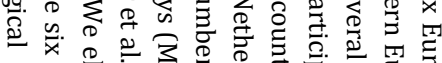

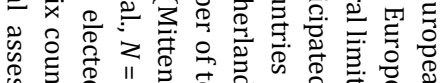

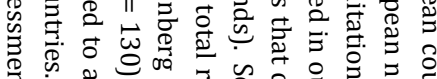

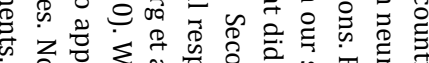
>

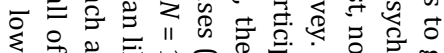

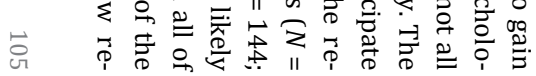

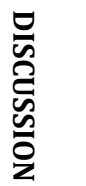

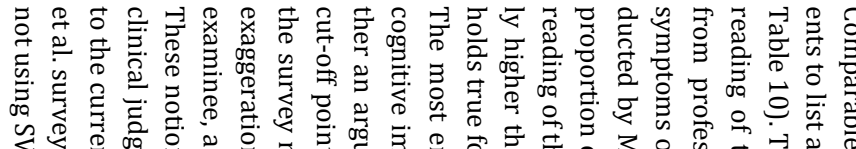

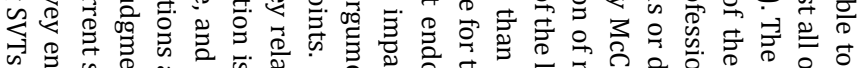

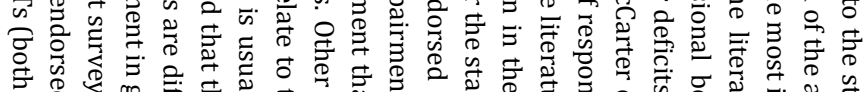

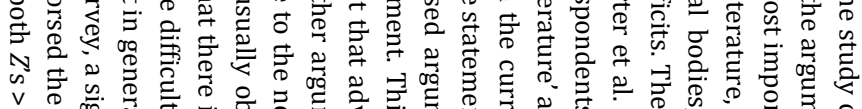

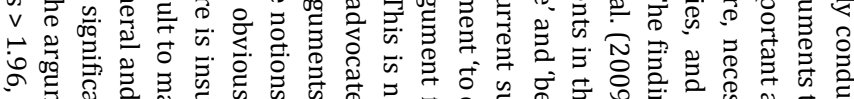

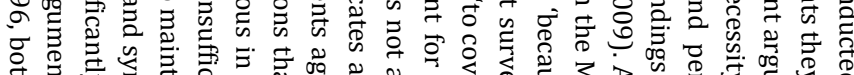

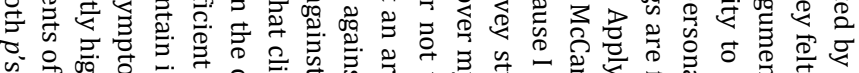

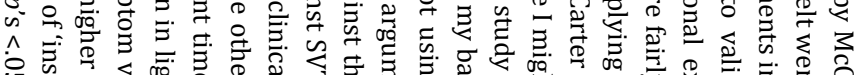

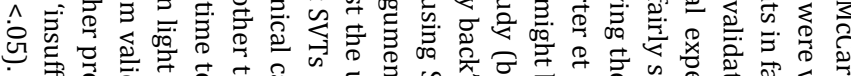

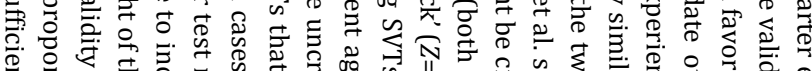

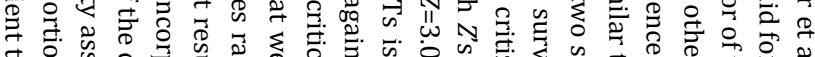

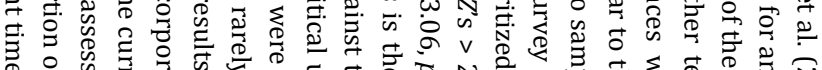

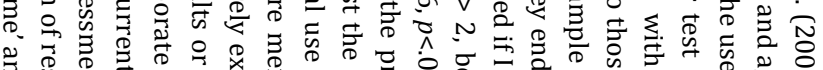

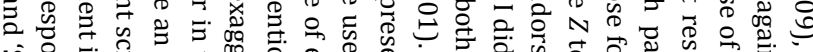

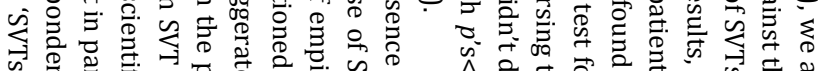

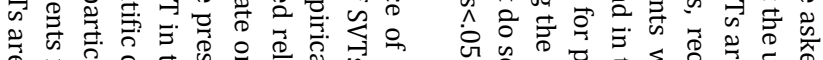

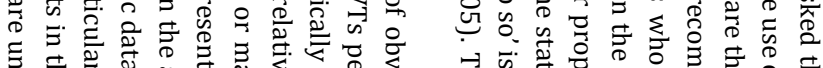

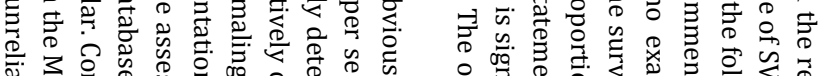

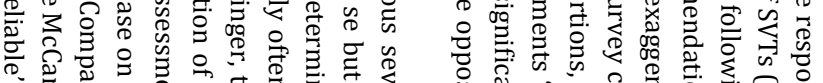

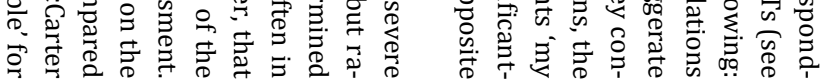




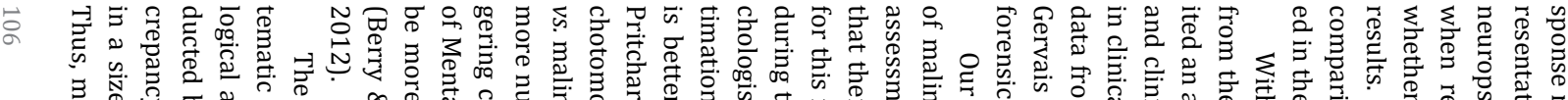

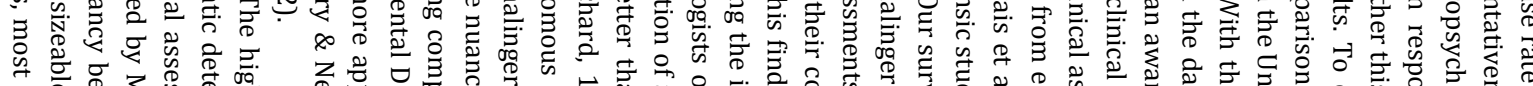

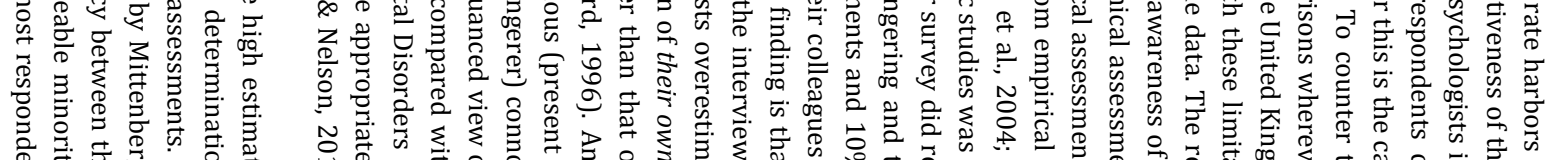

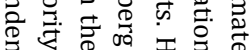
जि 0 i

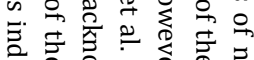

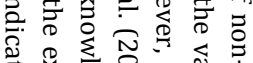

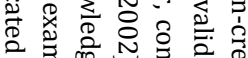

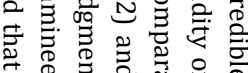

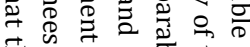

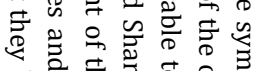

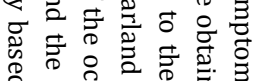

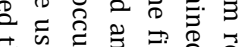

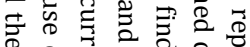

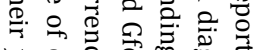
둥유

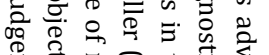
路

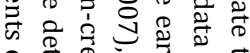
유율

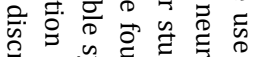

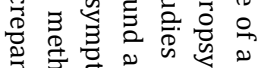

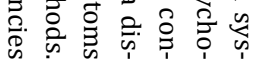

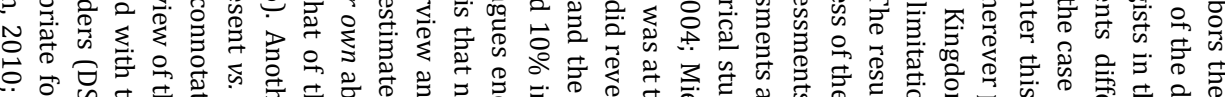

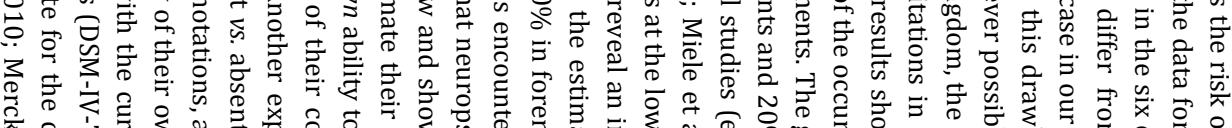

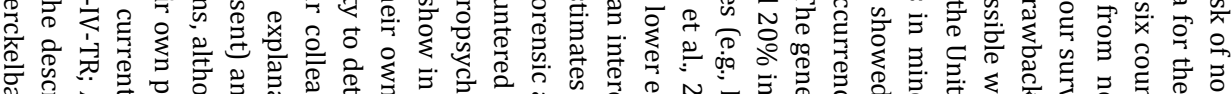

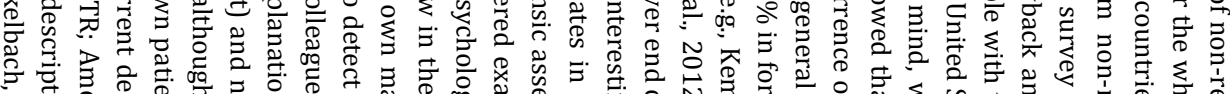

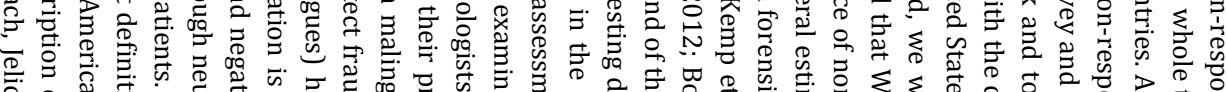

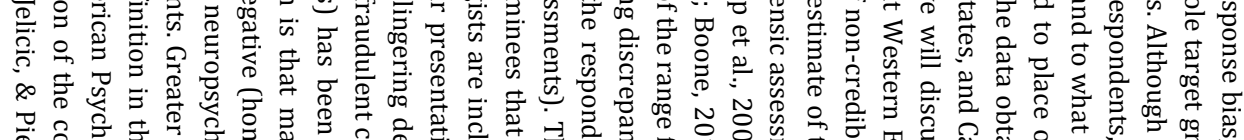

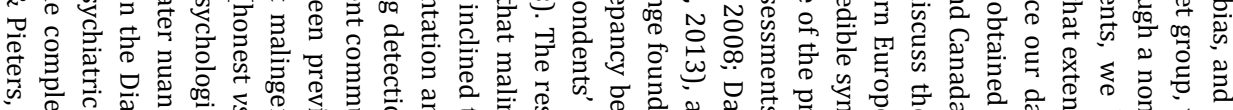

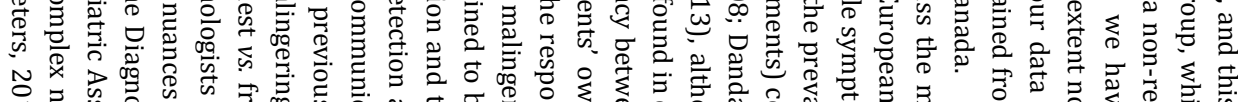

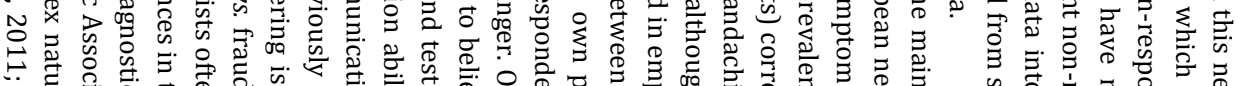

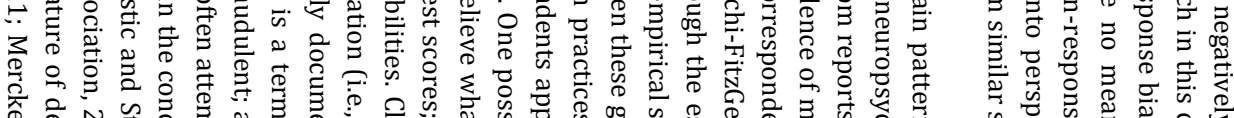

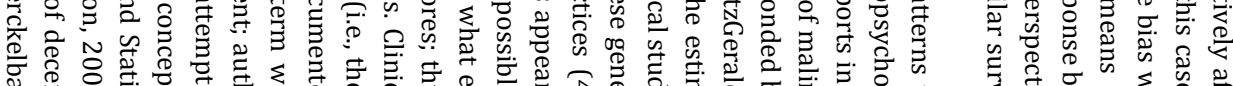

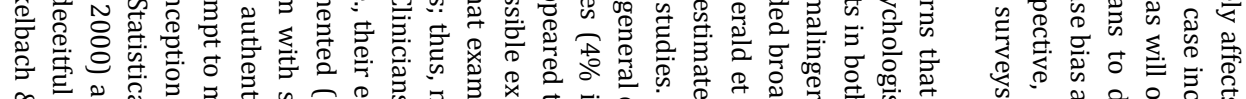

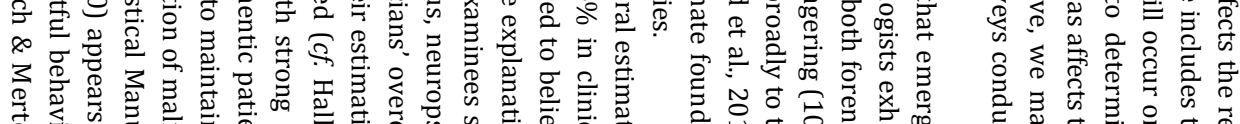

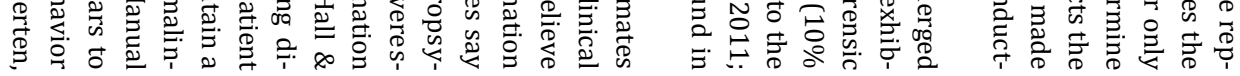

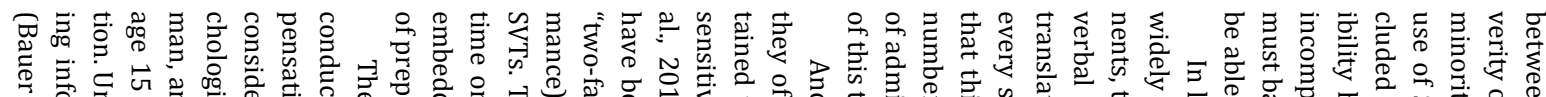

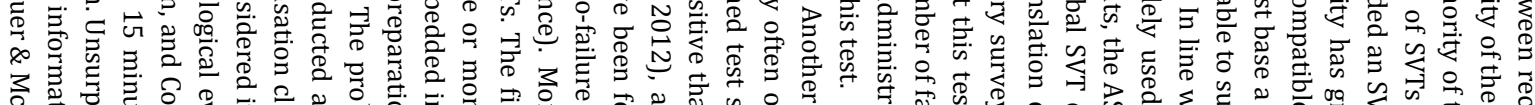

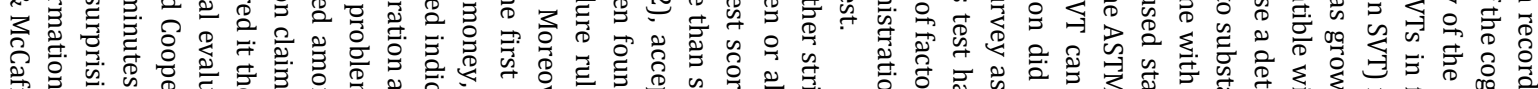

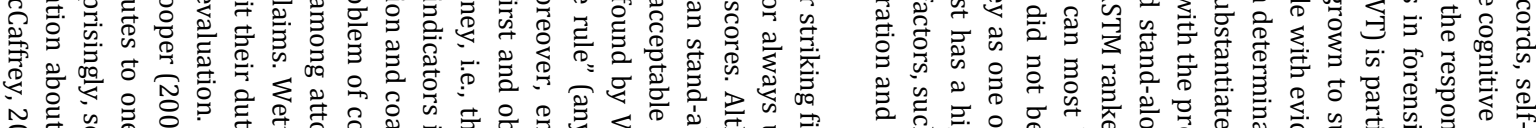
N

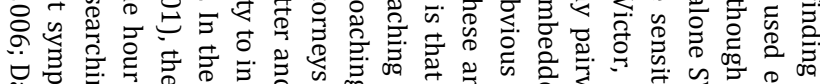

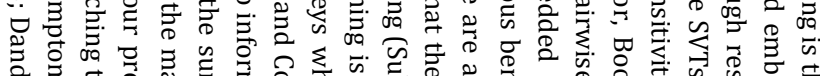

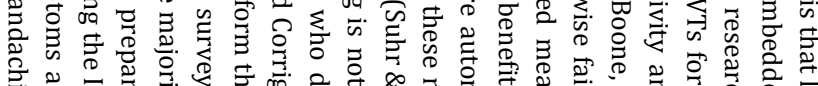

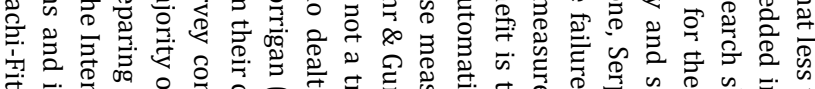

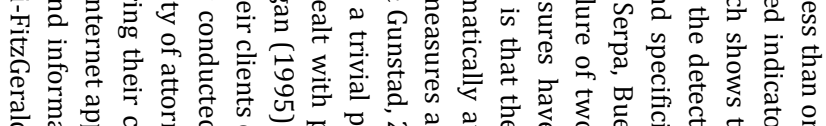

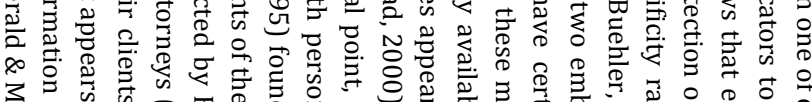

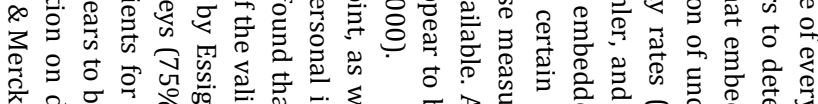

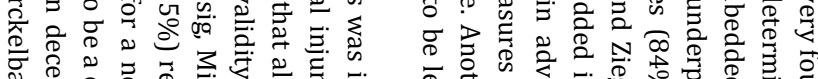

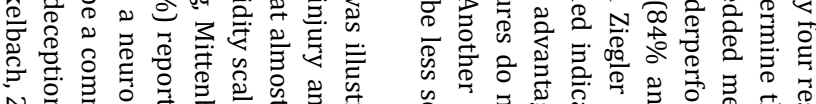

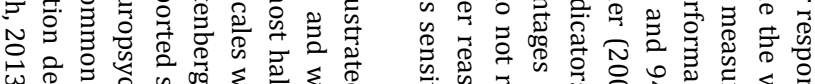

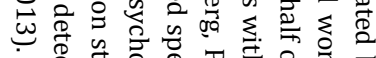

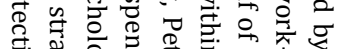

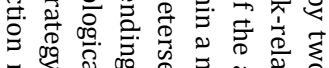

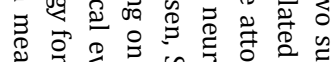

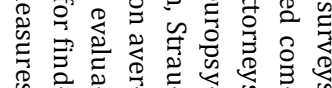

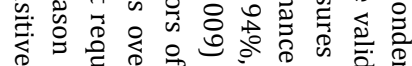
ठ

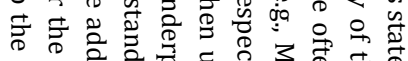

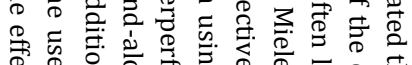

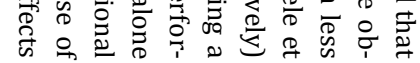

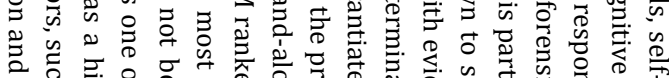

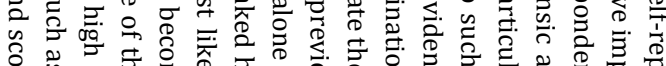

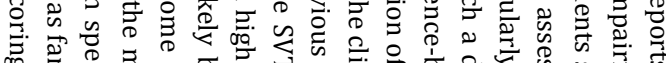
政节.

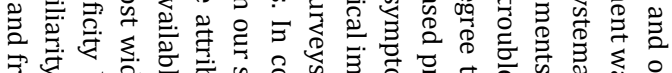

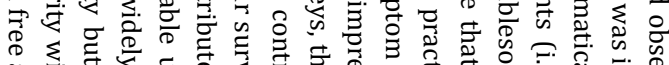

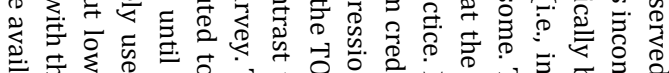

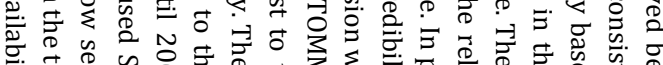

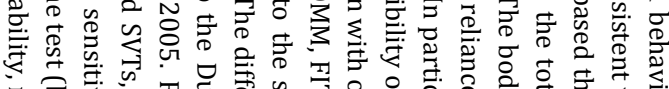

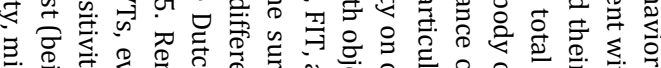

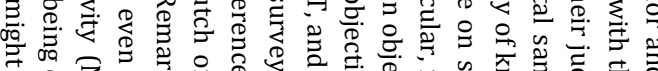

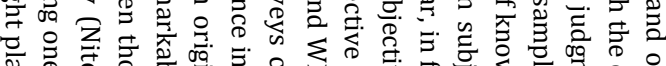

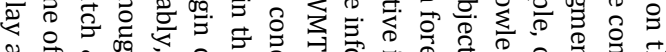

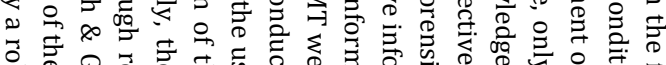
क क

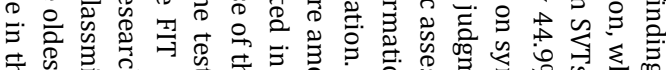

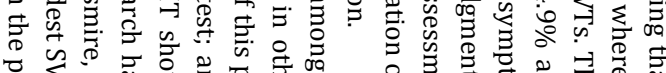

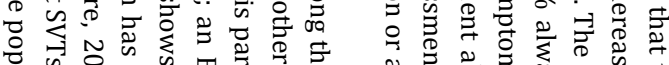

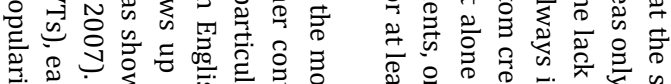

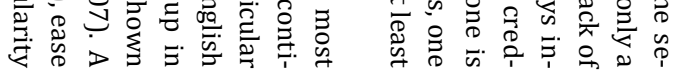




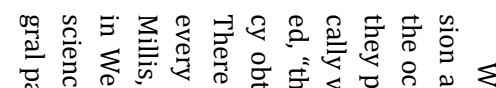

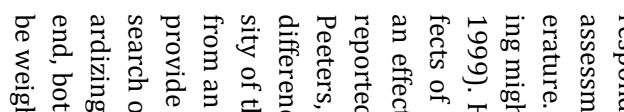

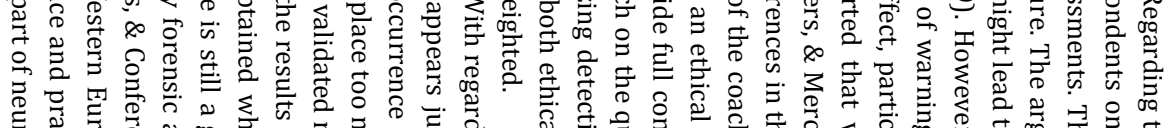

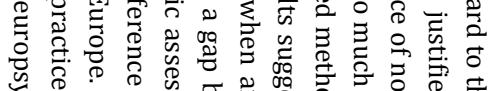

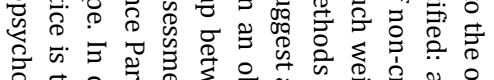

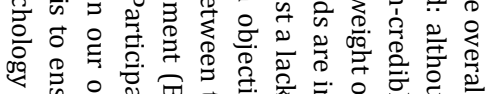

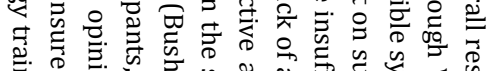

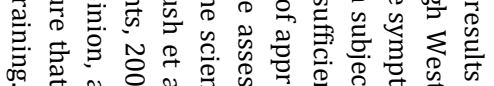

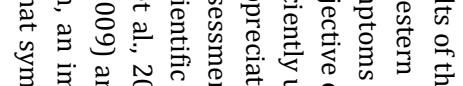

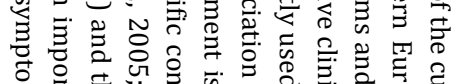

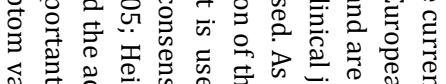

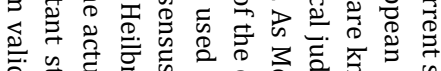

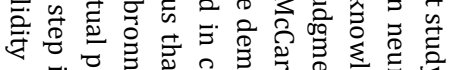
ming

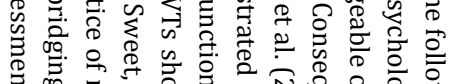

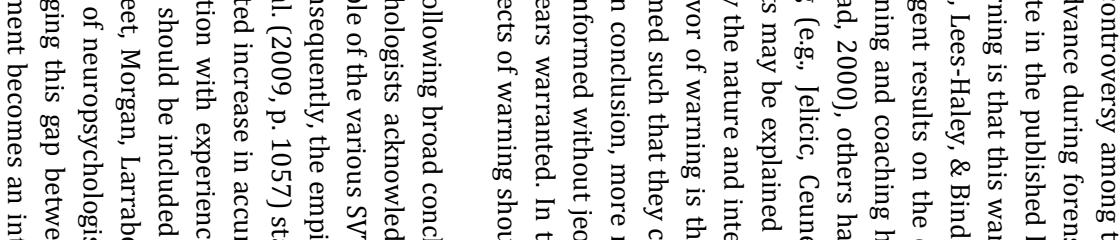

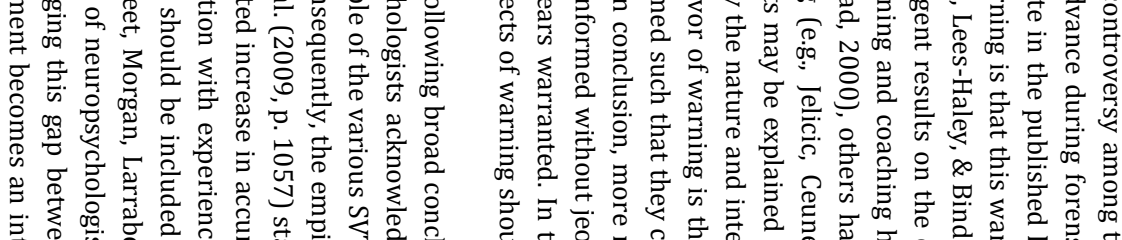

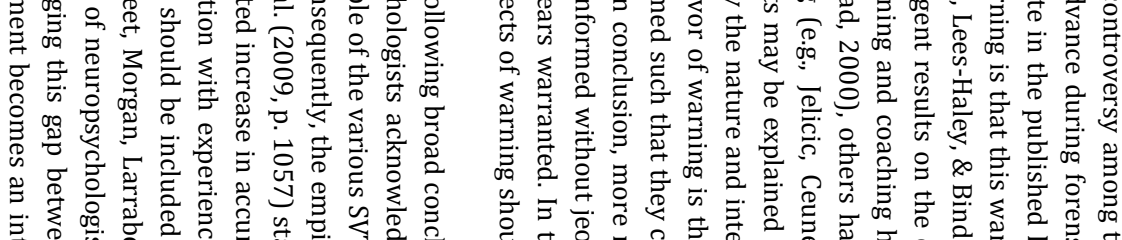

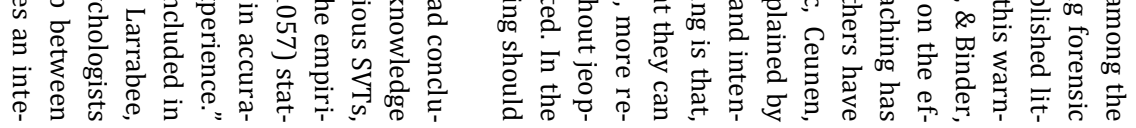

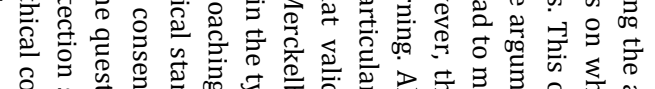

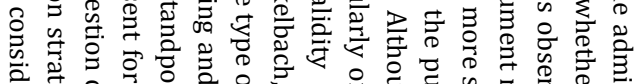

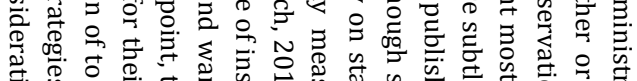

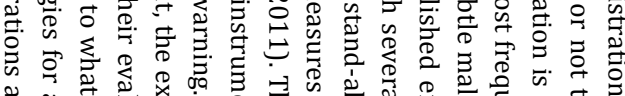

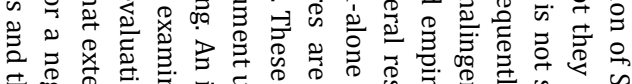

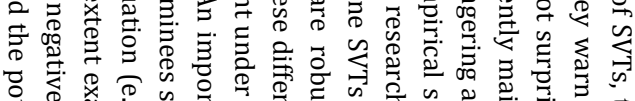

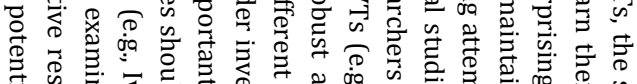

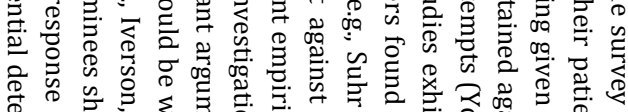

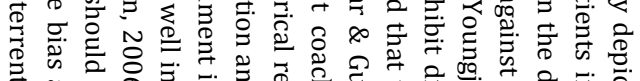

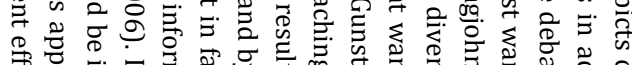

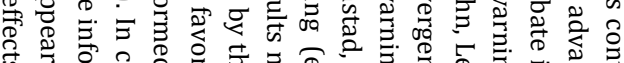
के जि

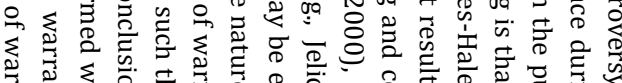

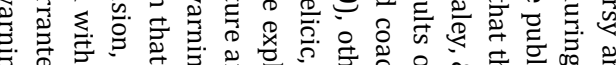

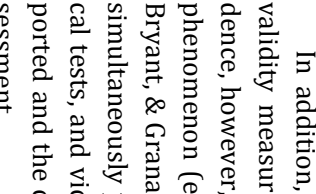
ชิ

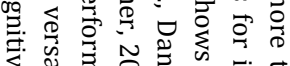
ब.

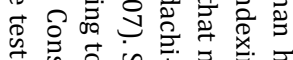

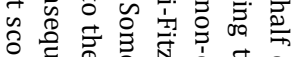

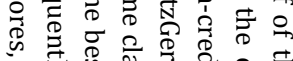

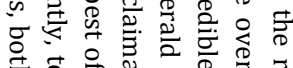

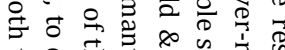

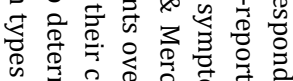

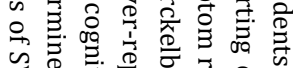

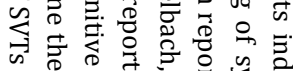

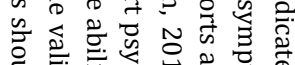

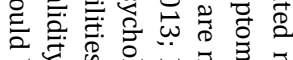

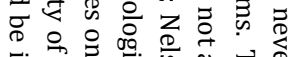

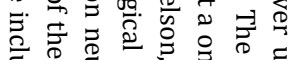

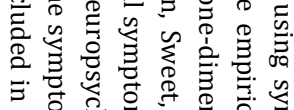

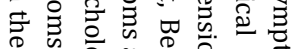

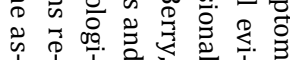

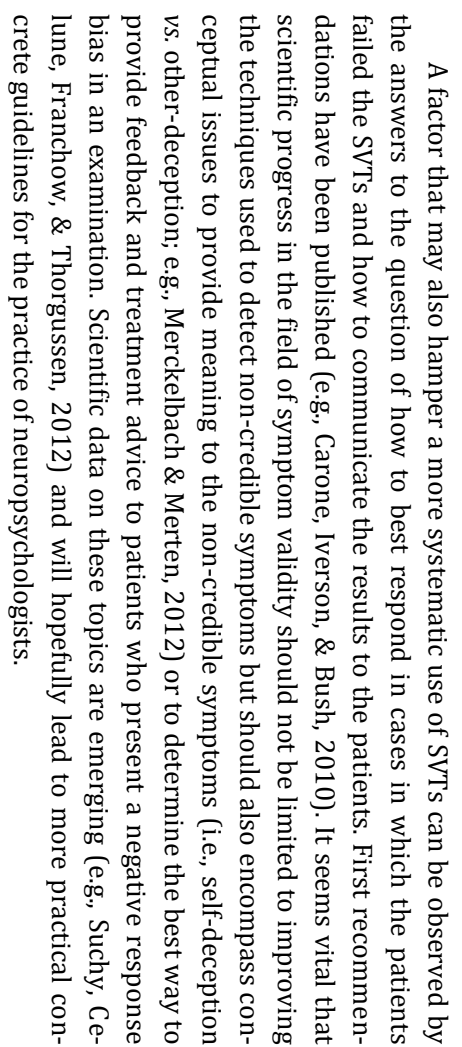



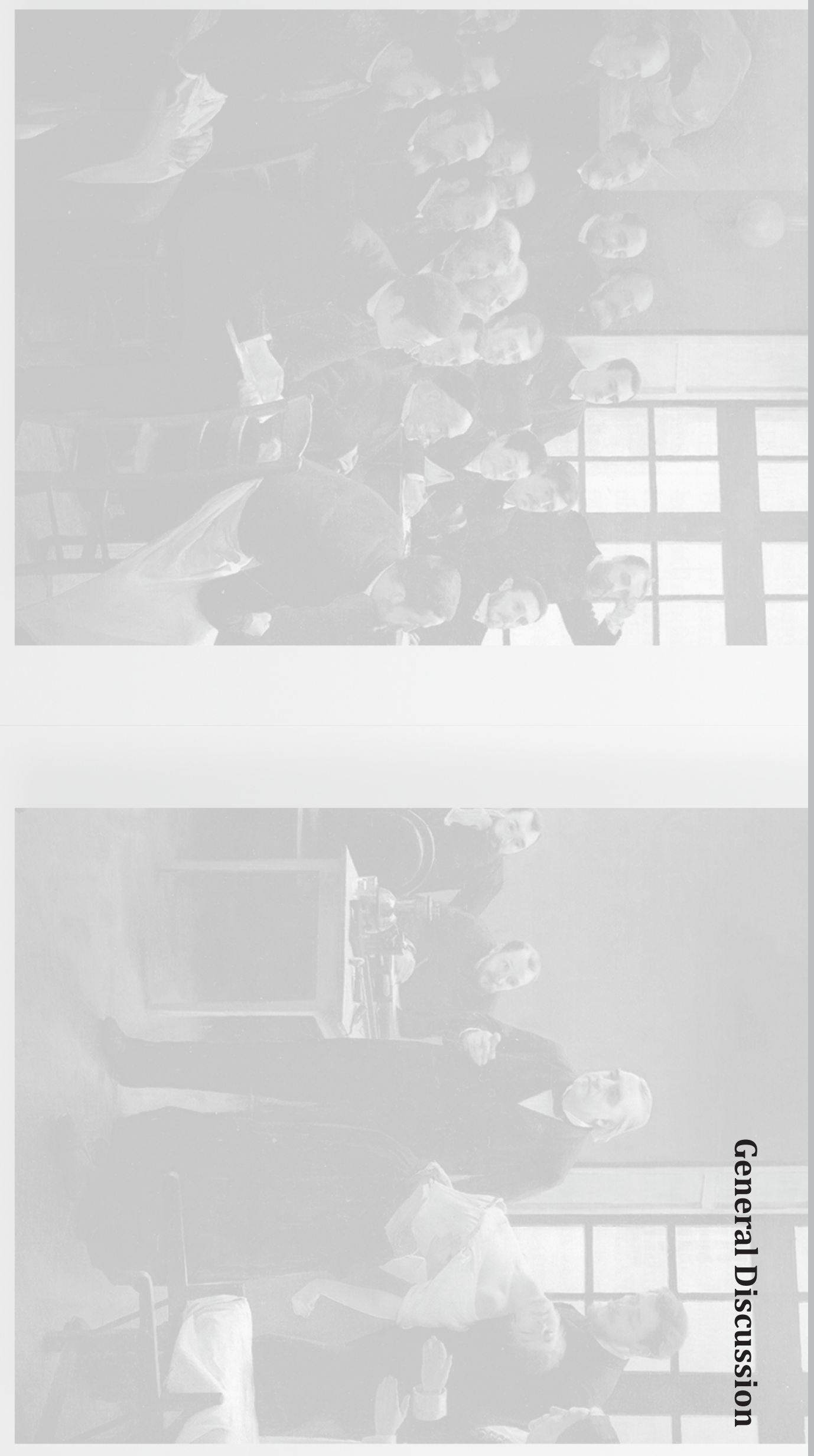

롤

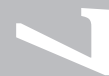




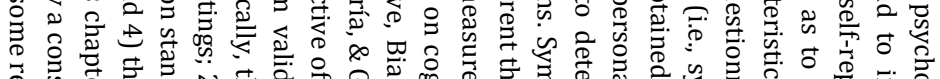

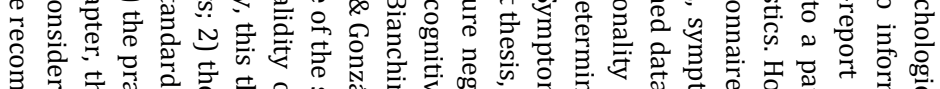

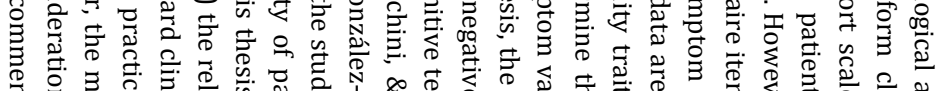

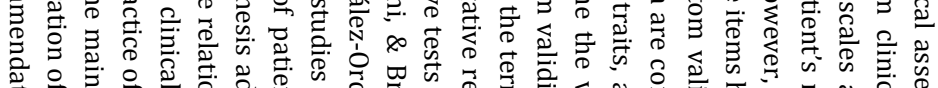

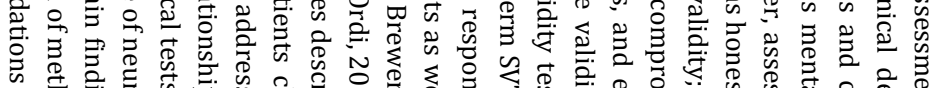

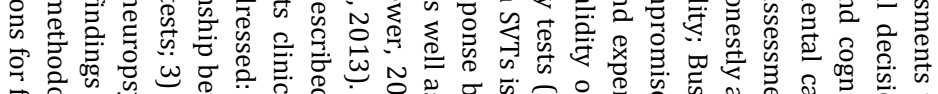

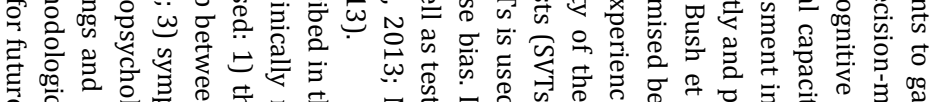

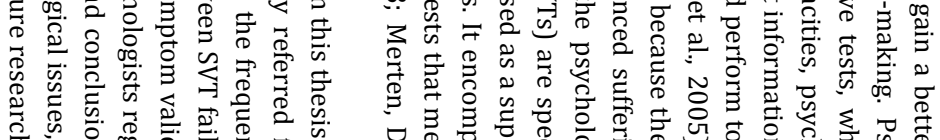

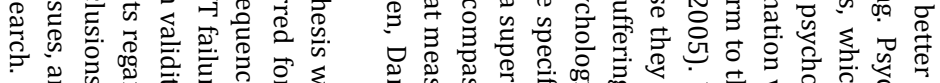

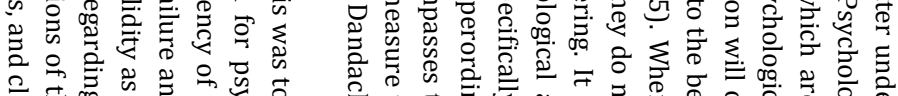

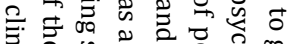
突.

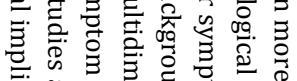

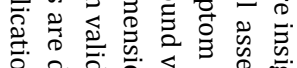

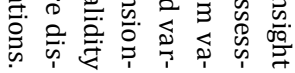

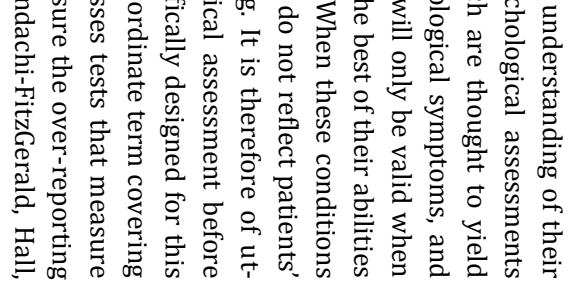

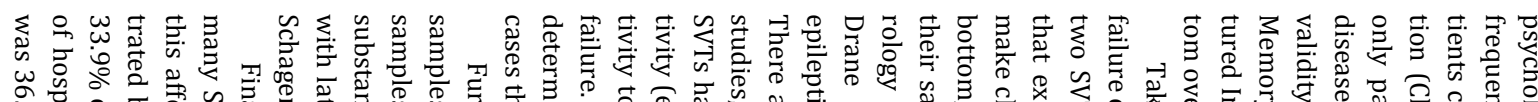

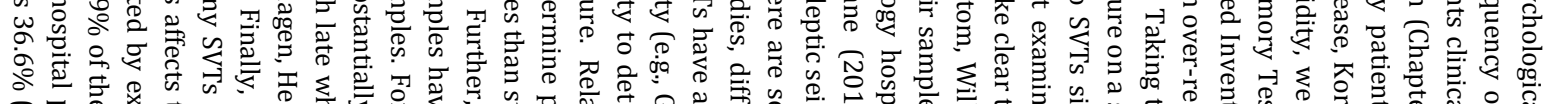

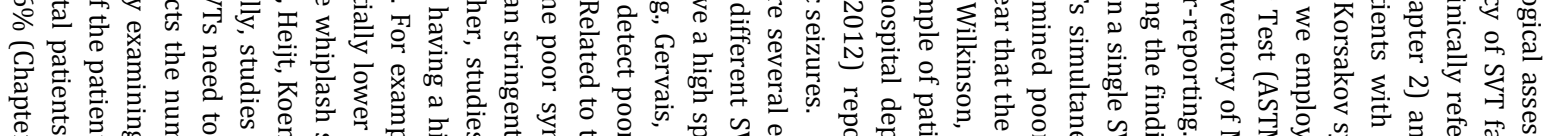

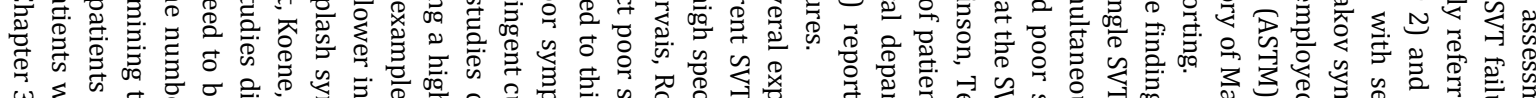

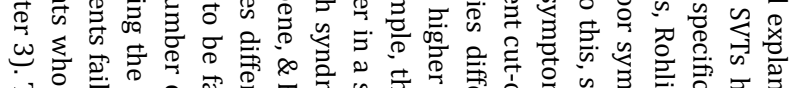

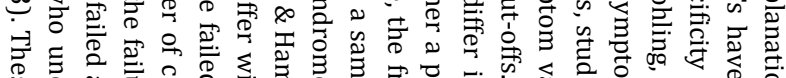

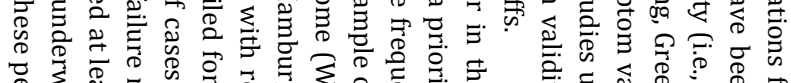

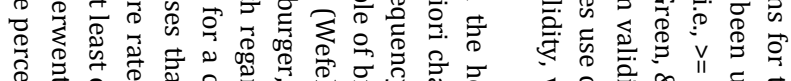

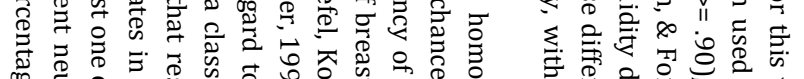

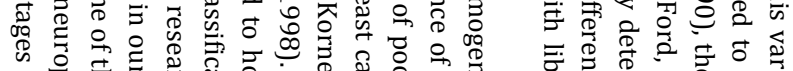
क (1) ¿

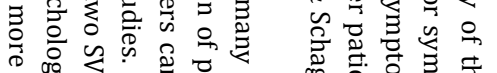
० og.

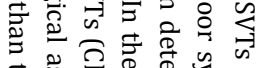

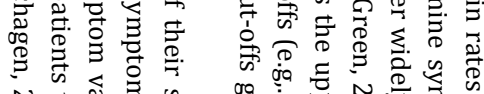

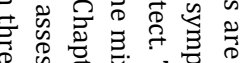

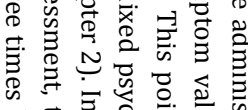

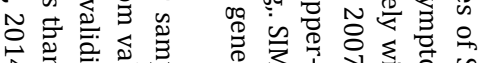

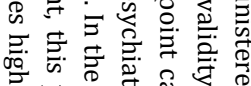
จ

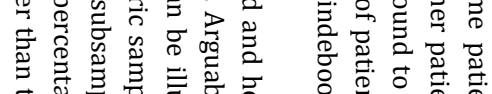

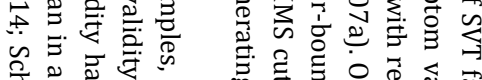

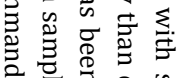

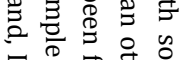

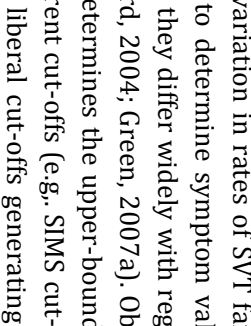

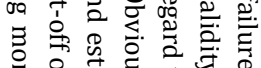

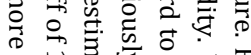

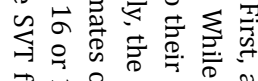

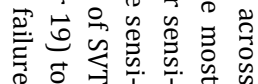

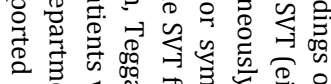

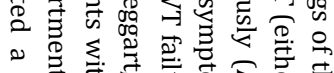

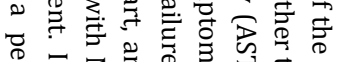

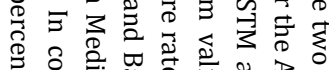

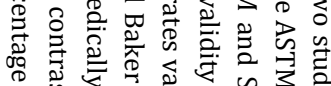

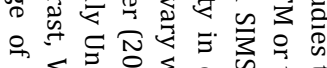
w

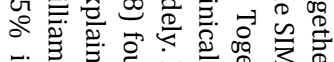

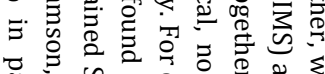
ๆ

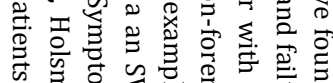

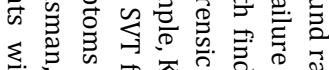

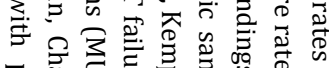

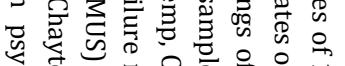

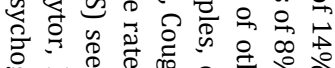

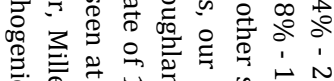

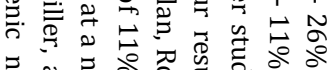

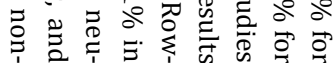

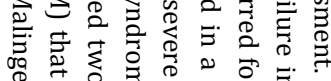

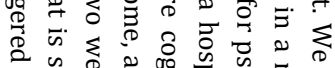

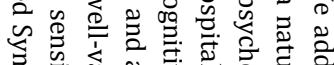

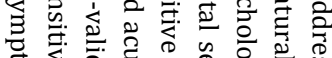

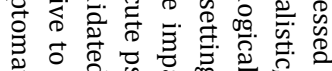

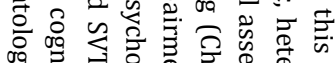

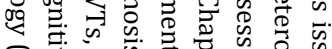

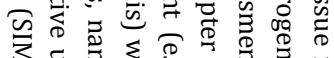

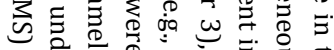

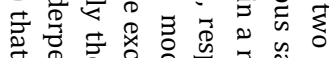

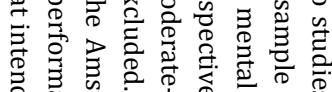
के

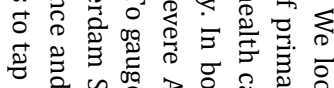

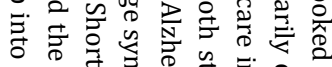

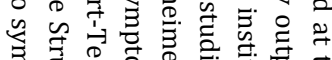

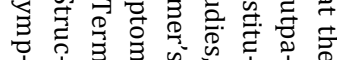




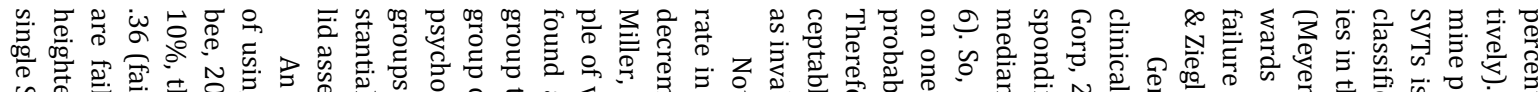

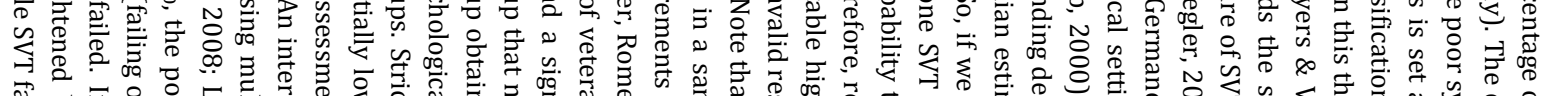

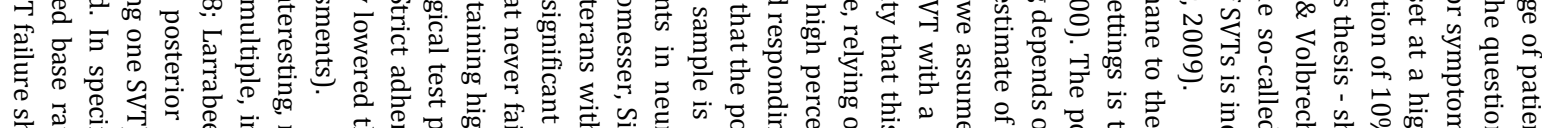

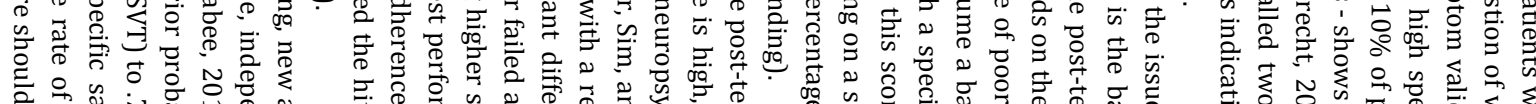

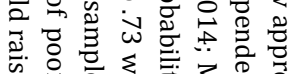
萬. 仓ิ)

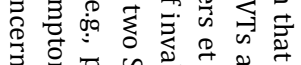

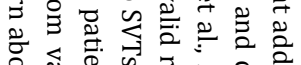

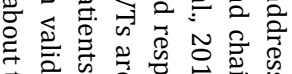

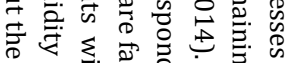

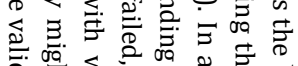

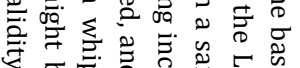
둥

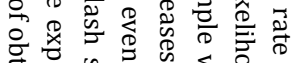
它. D

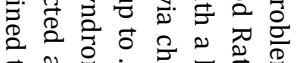

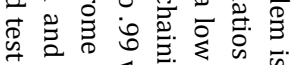

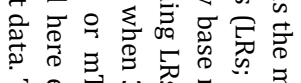

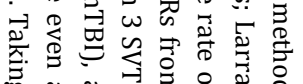

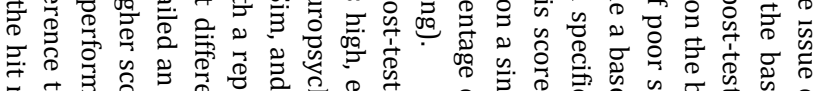

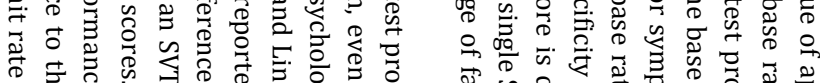

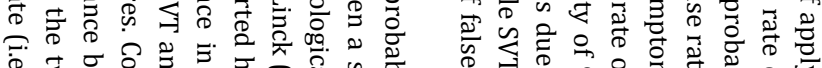

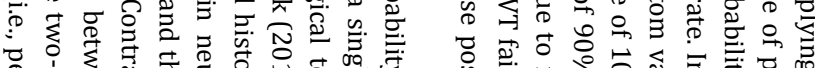
च

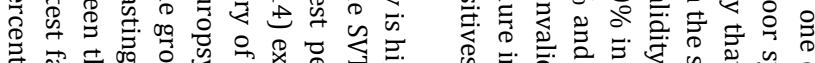

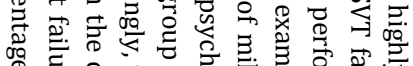
品

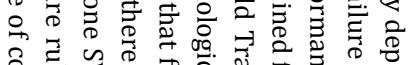

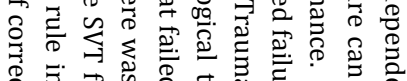

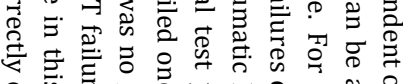

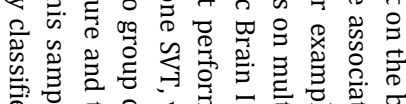

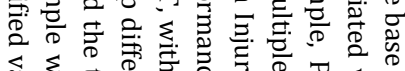

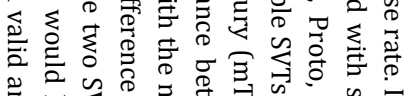

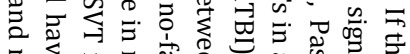

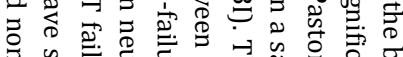

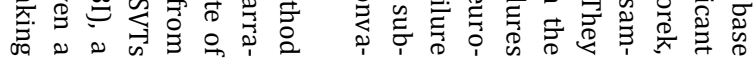

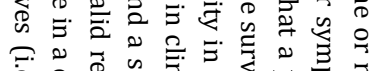

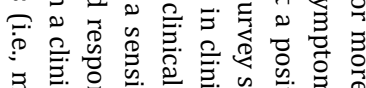

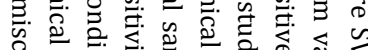

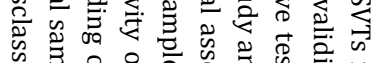

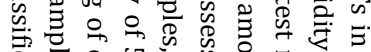

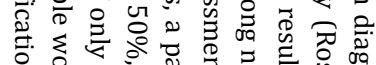

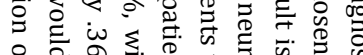

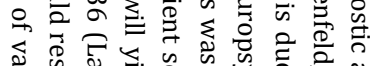

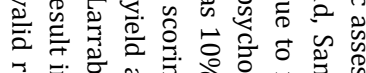

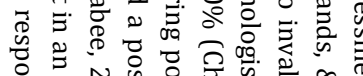

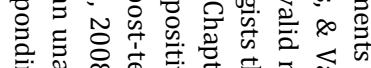
उं ‥

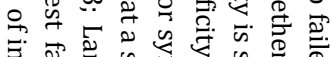

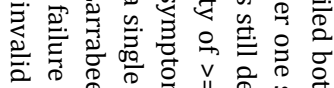

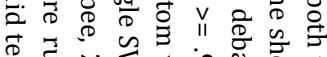
语

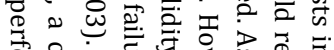

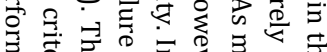

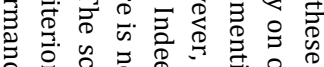
సั

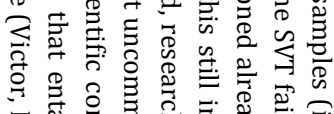

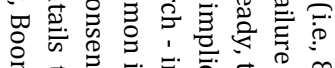

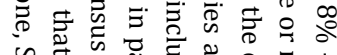

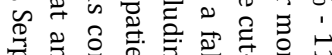

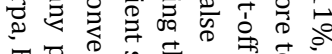

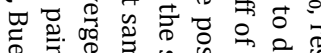

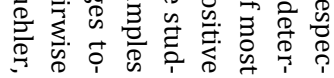

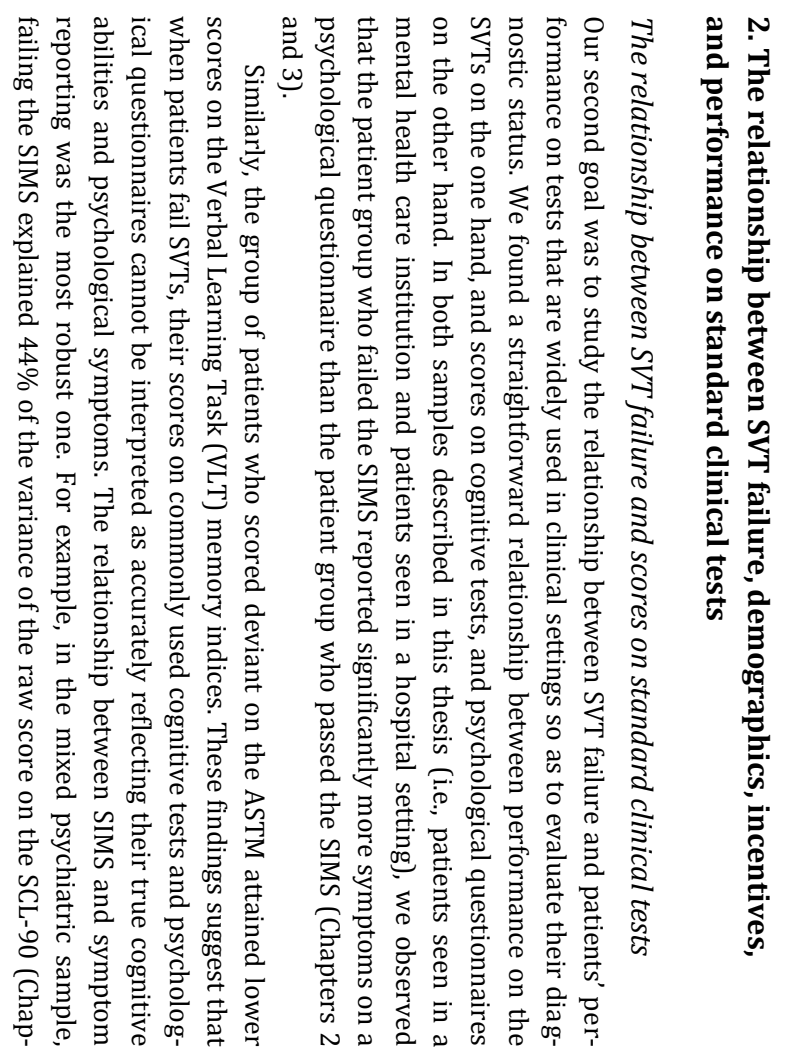

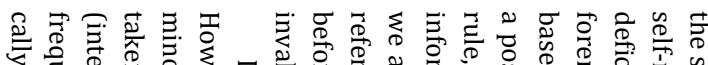

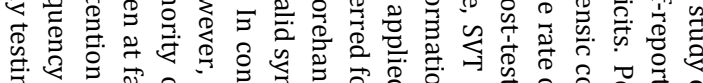

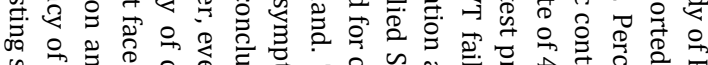

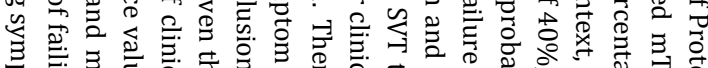

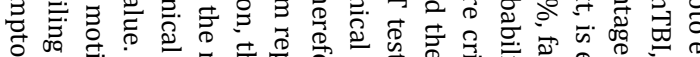

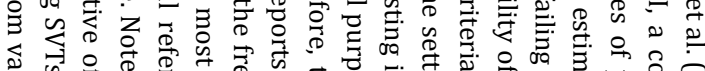

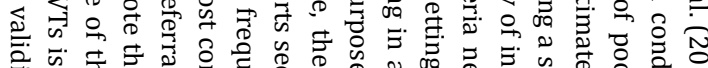

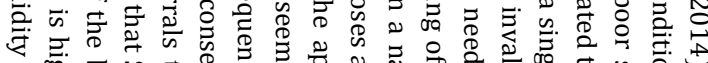

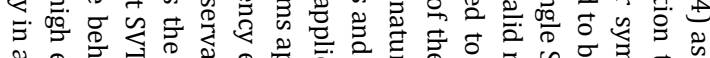

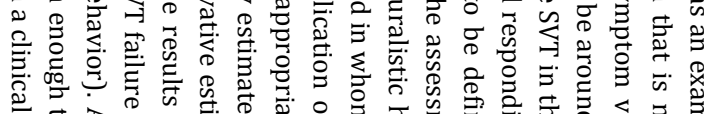

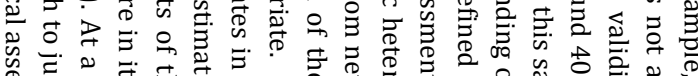

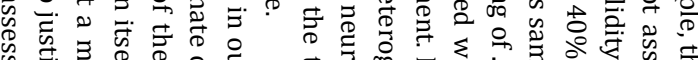

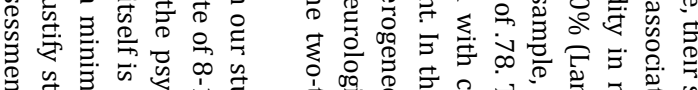

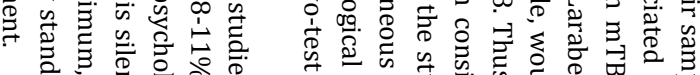
它 引ํ.

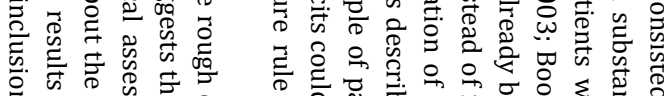

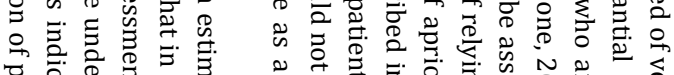
宓产

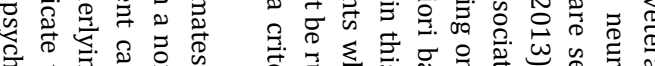

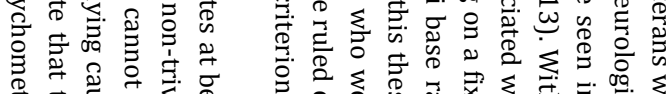

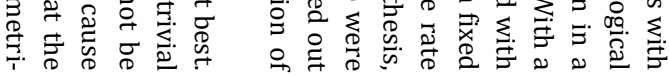




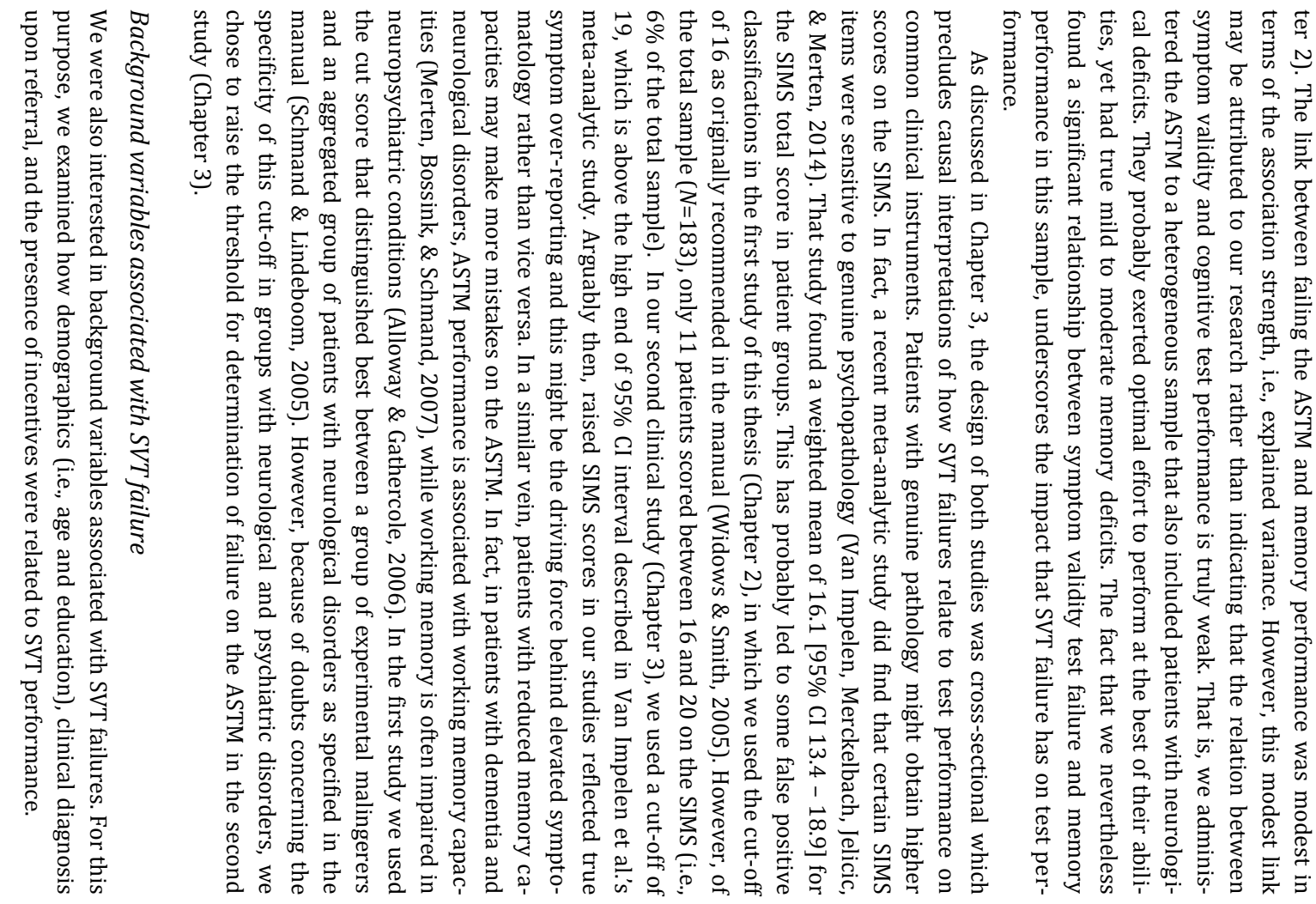

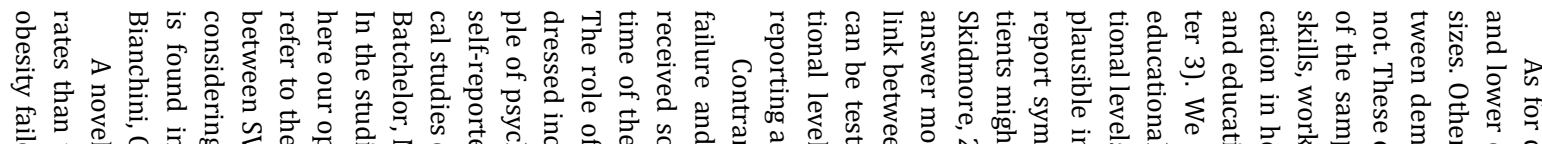

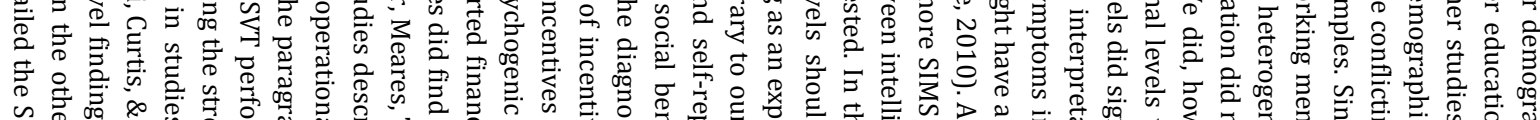

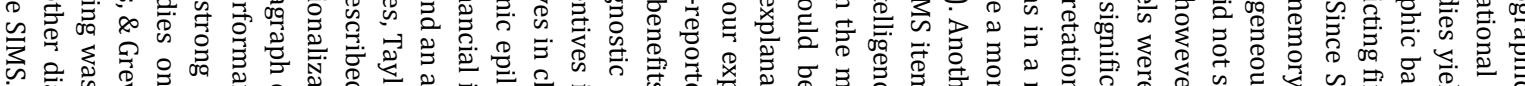

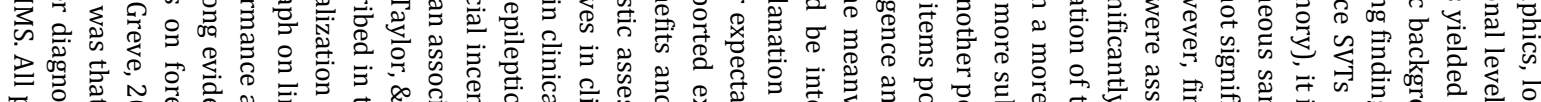

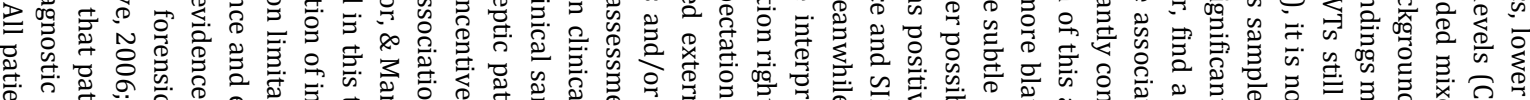

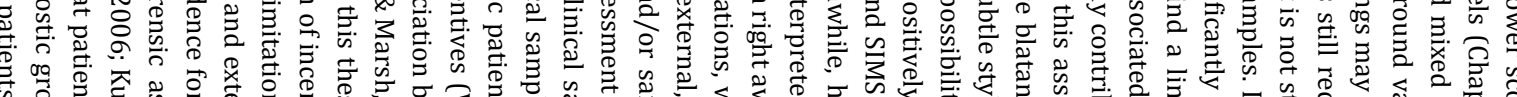

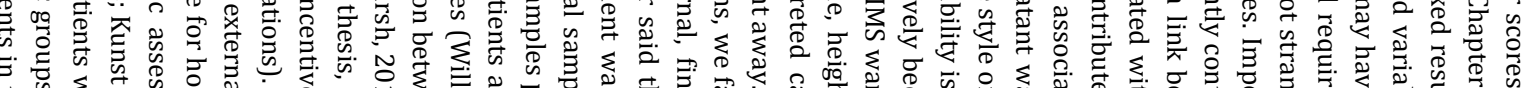

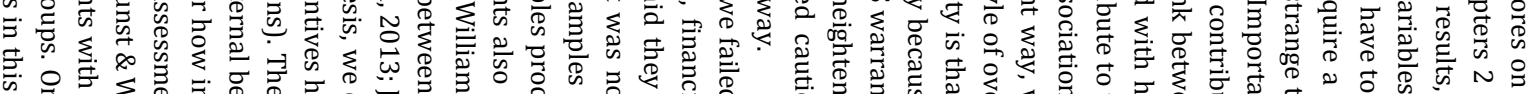

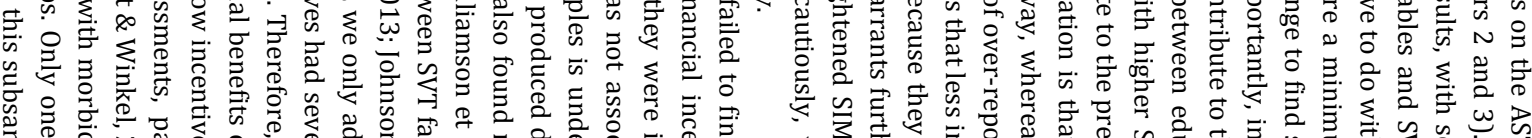

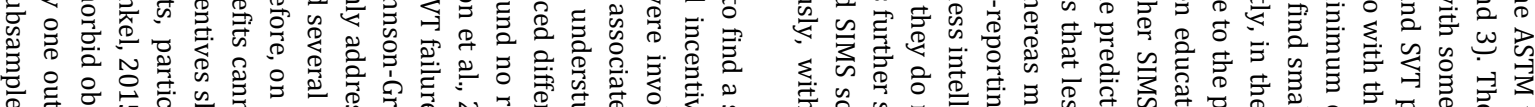

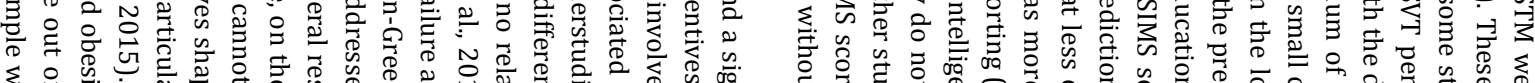

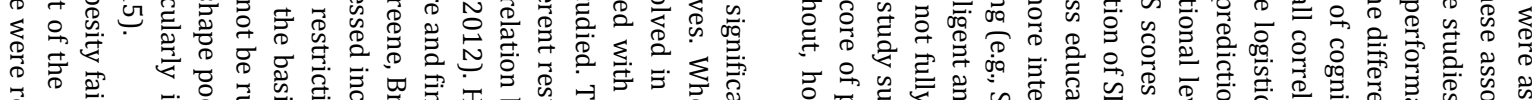

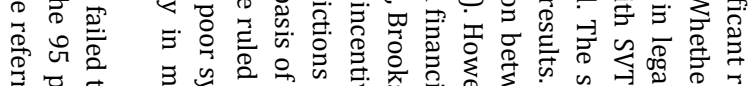

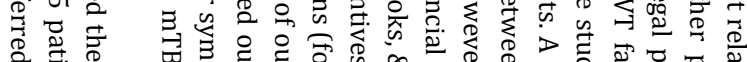

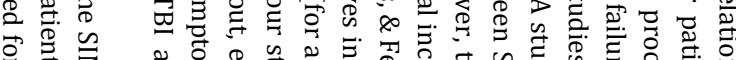

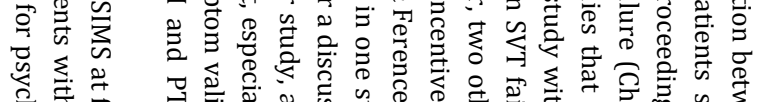

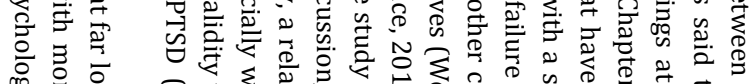

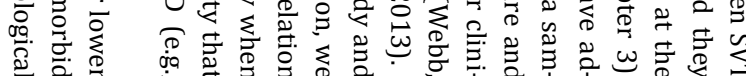

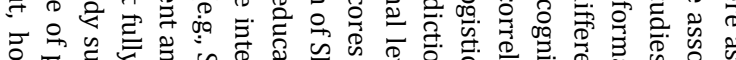

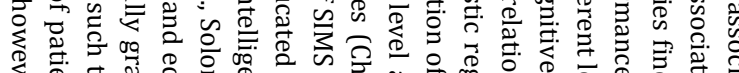

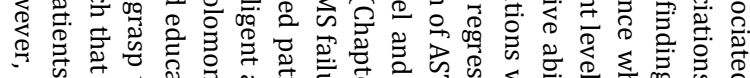

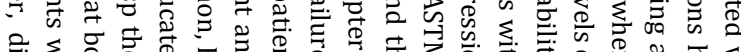

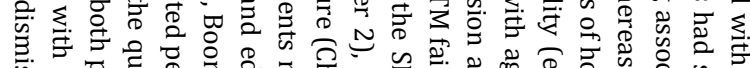

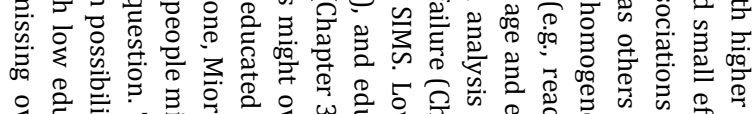

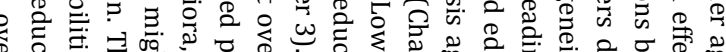




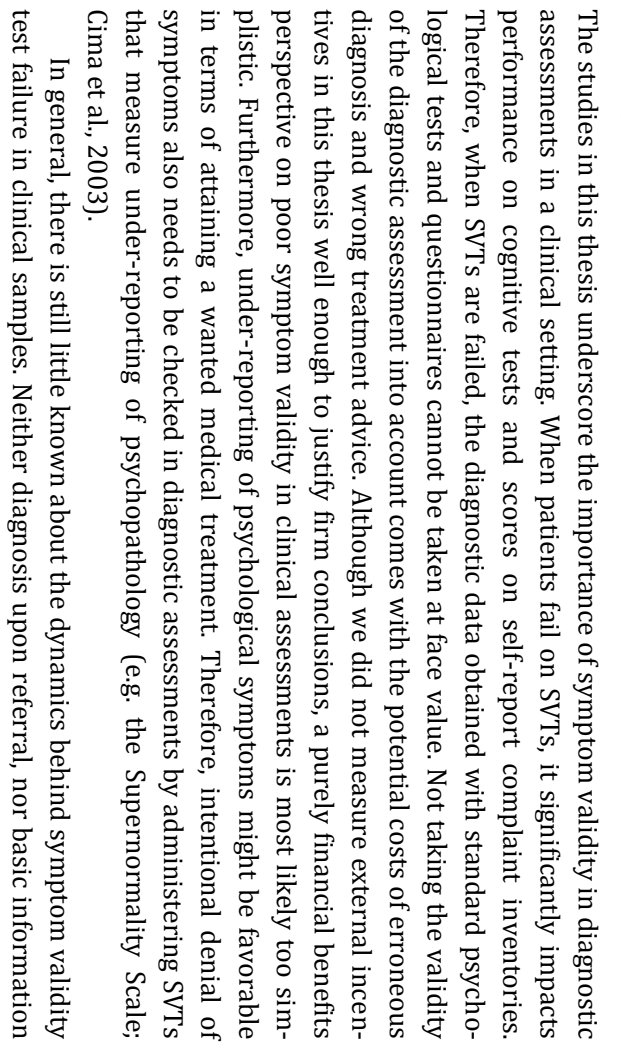

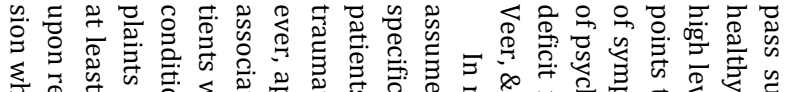

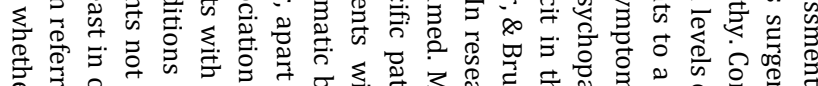

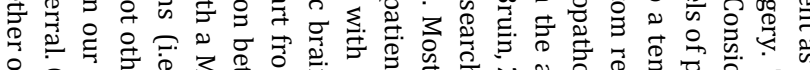

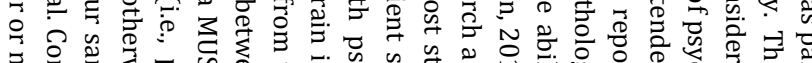

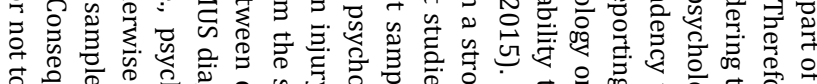

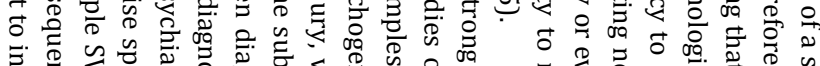

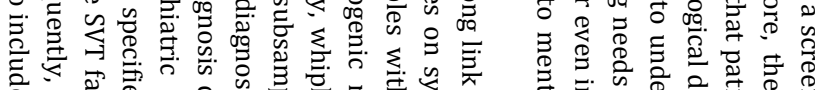

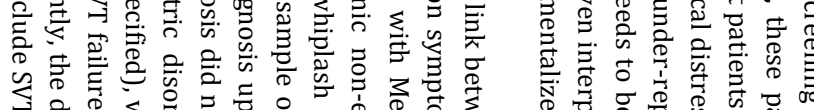

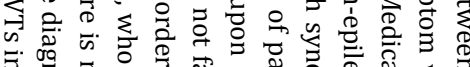

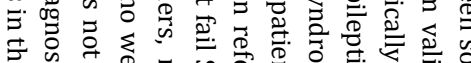
宲

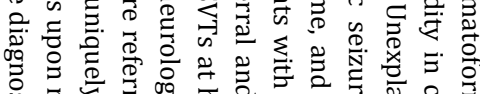

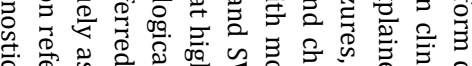

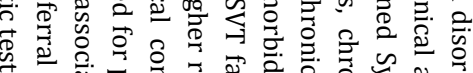

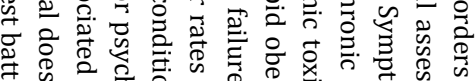

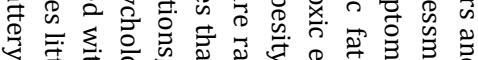

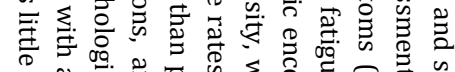

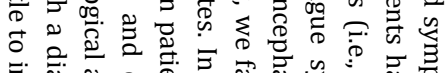

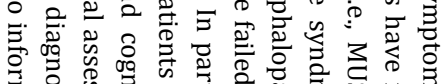

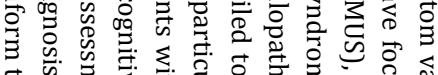

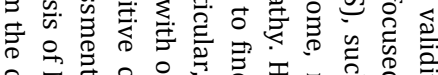

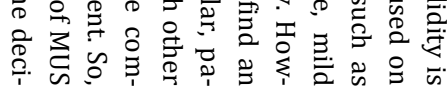
. E.

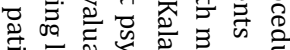

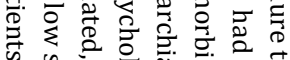

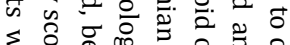

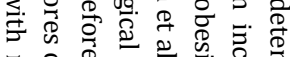

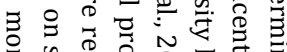

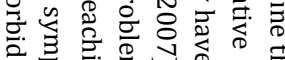
० क्व

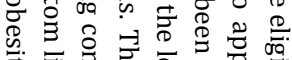
धँ ज्ञ

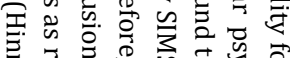

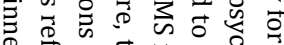
Ð

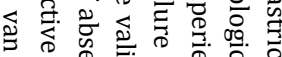

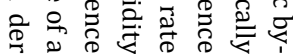

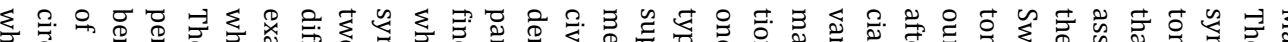

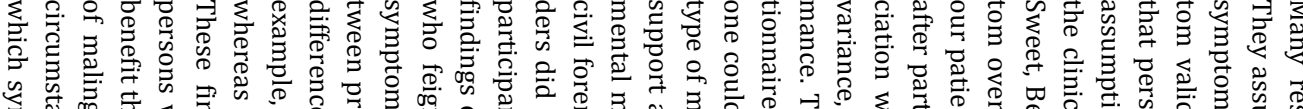

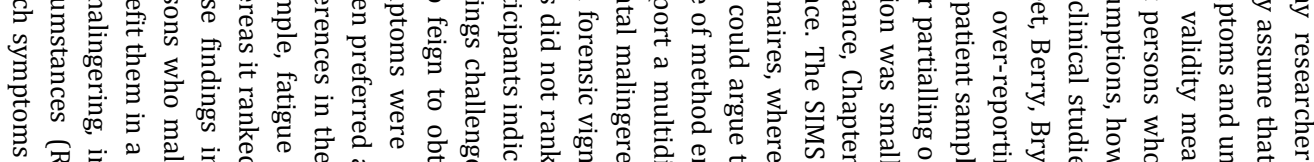
代

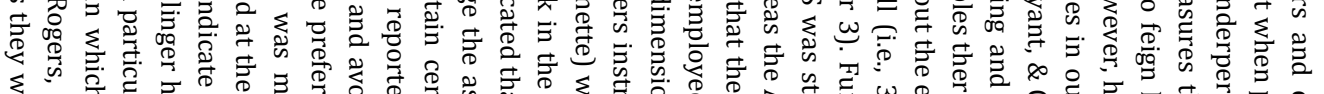

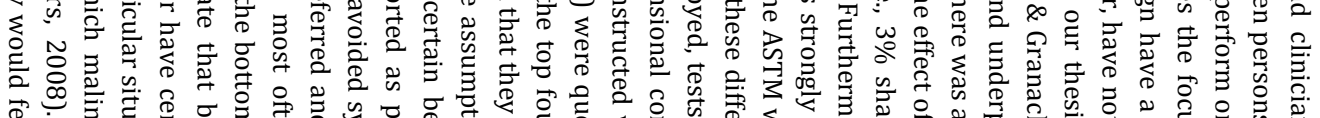

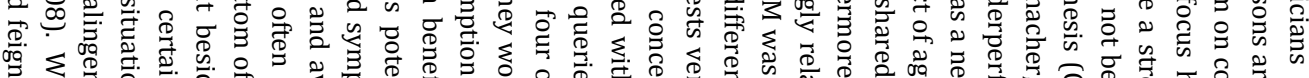

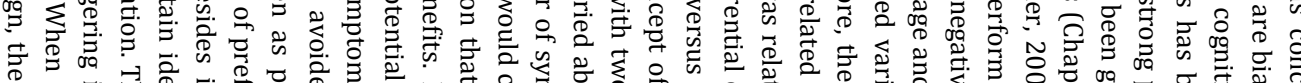

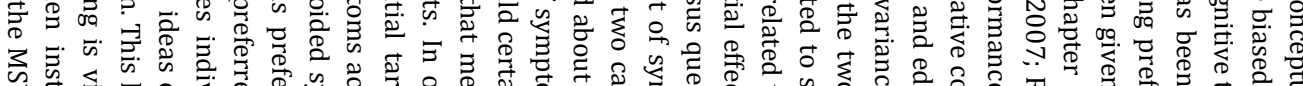

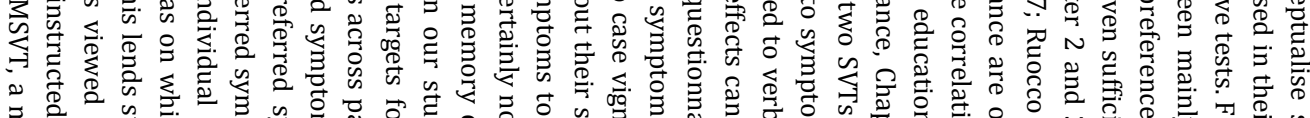

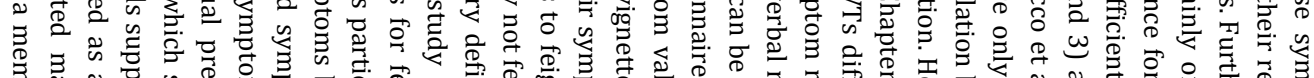
矛施

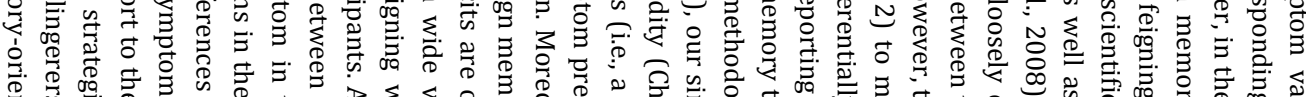

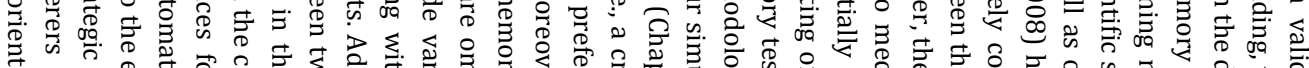

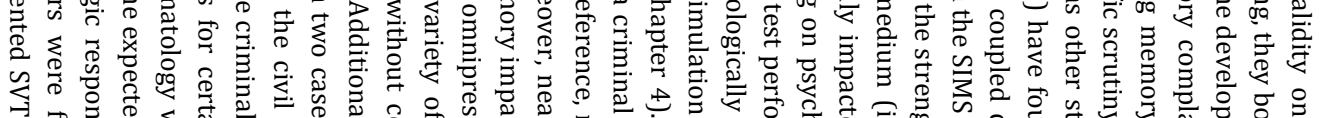

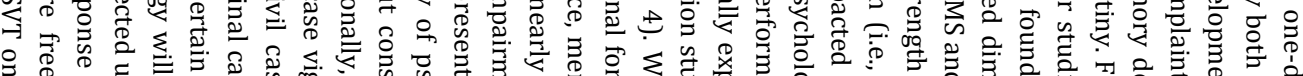

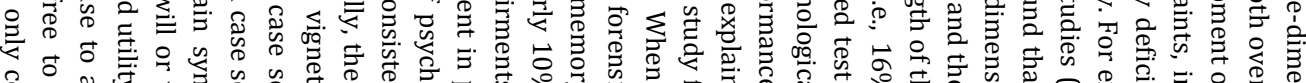

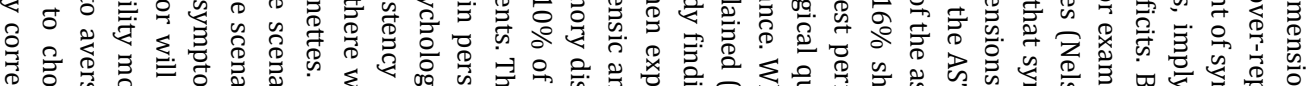

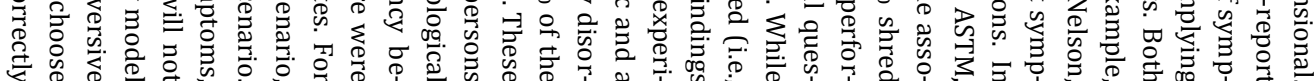

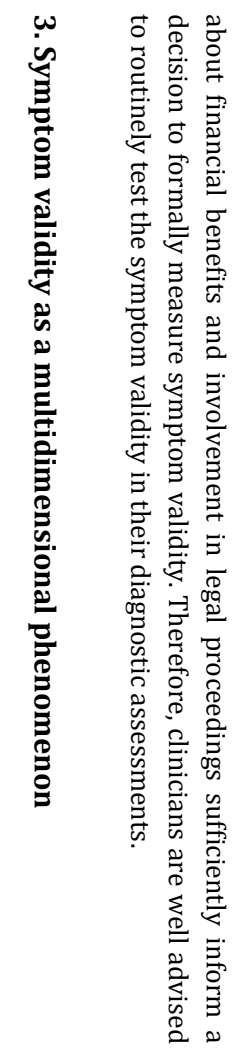




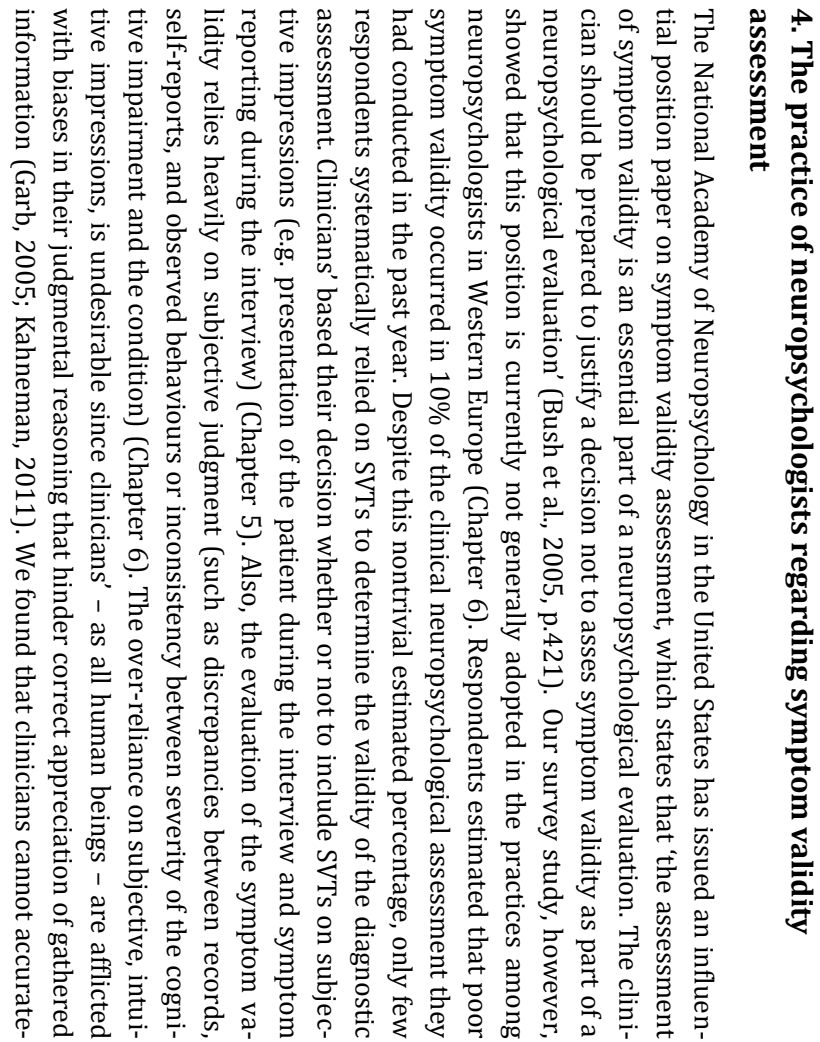

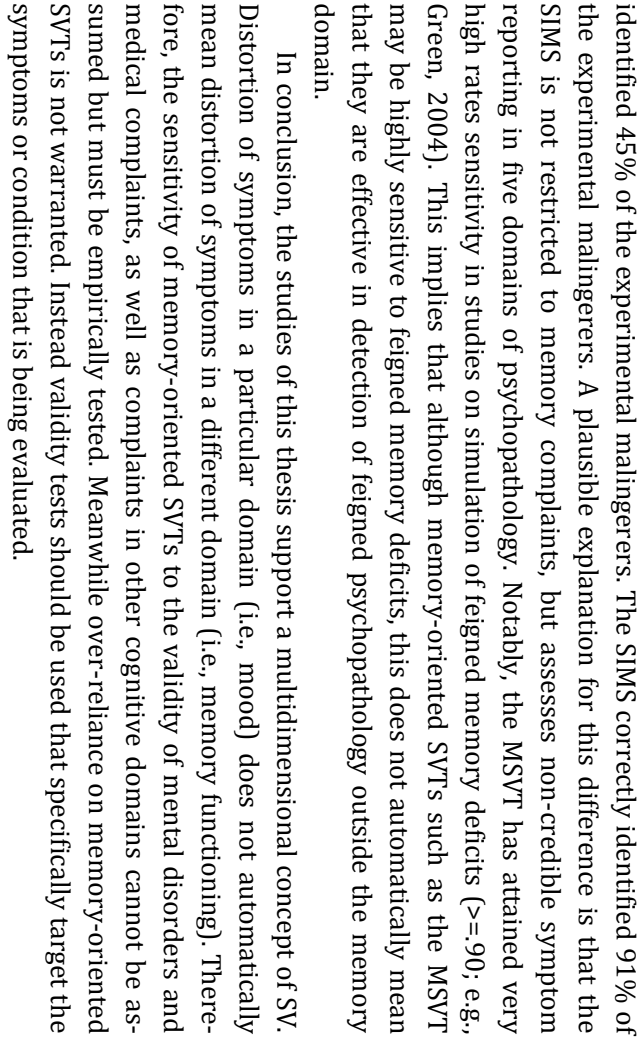

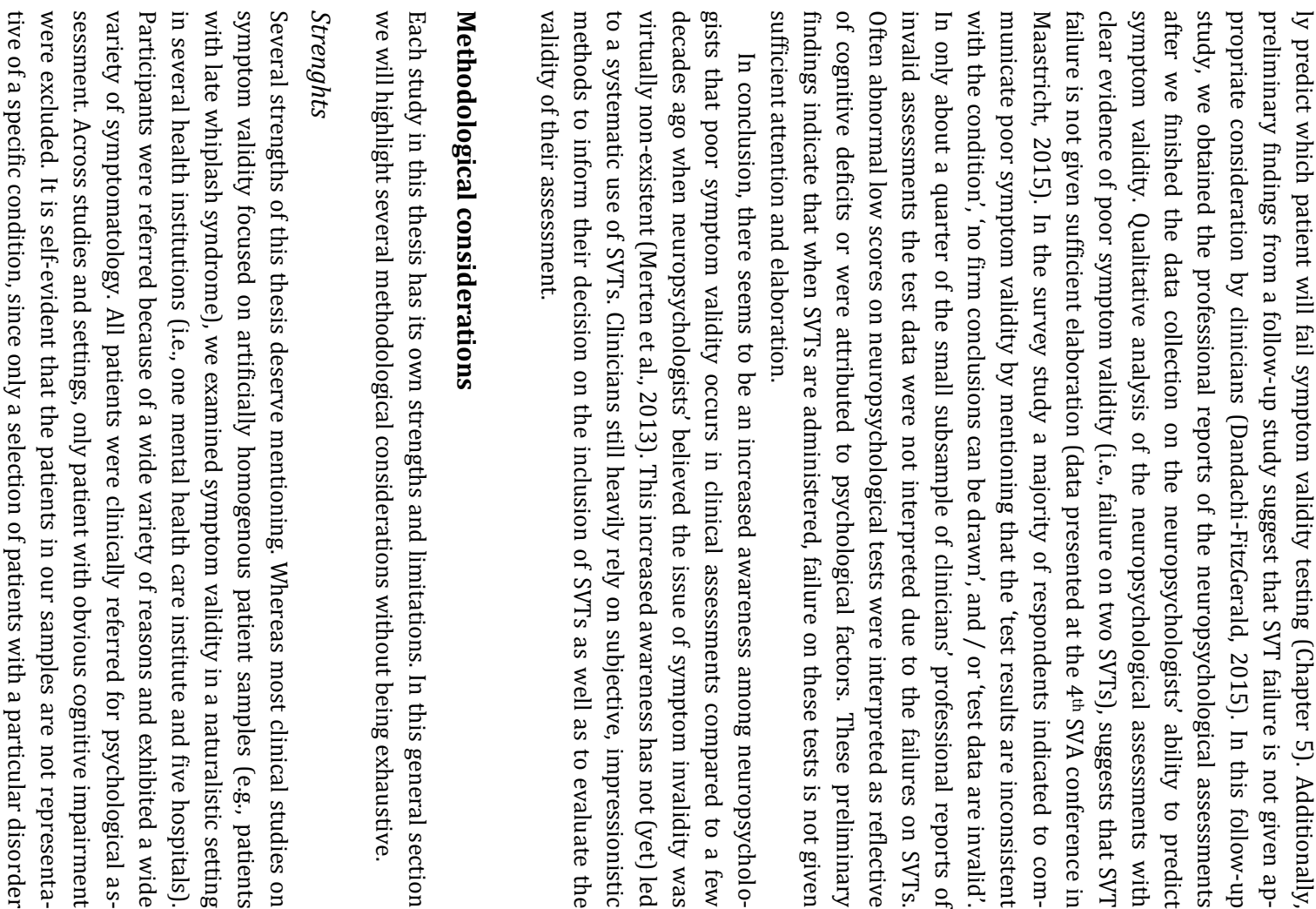




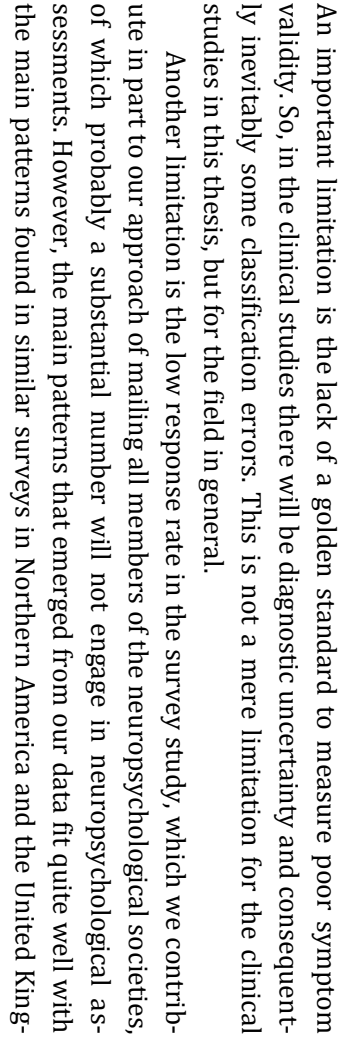

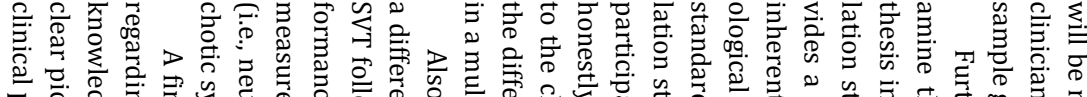

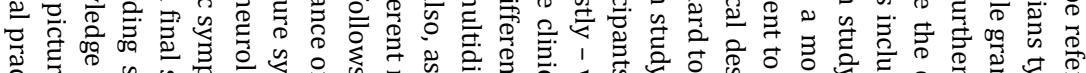

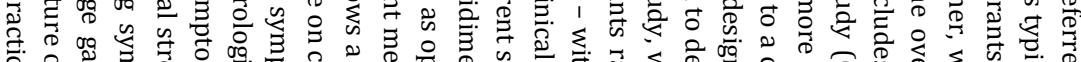

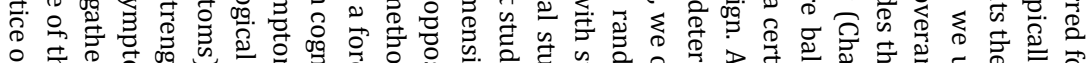

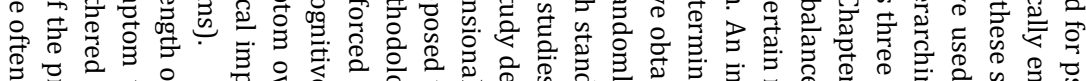

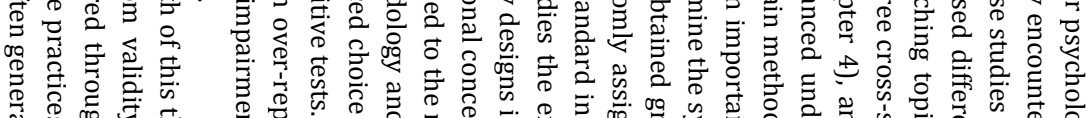

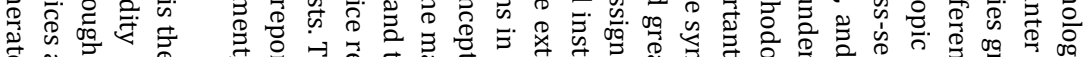
की

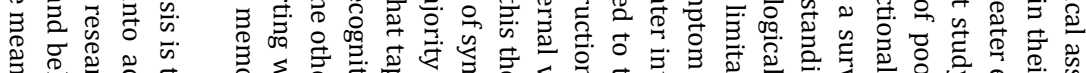

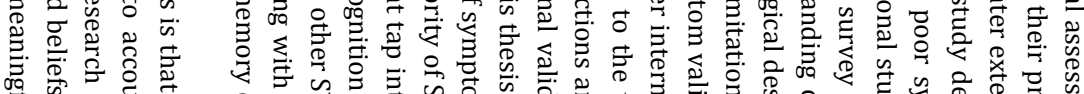

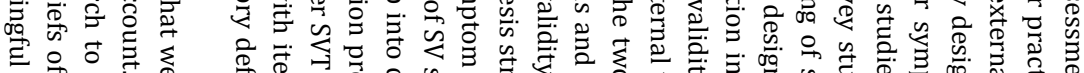

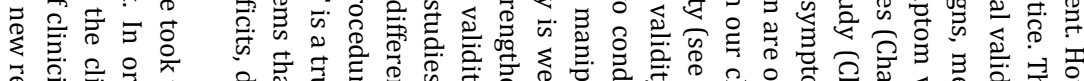
勇

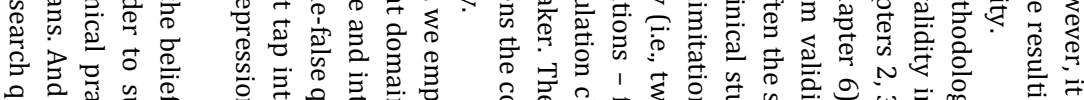

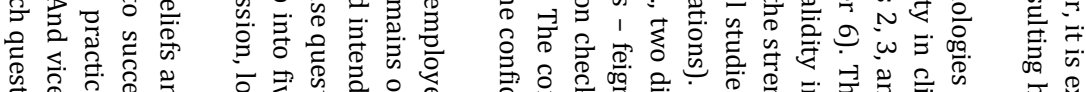

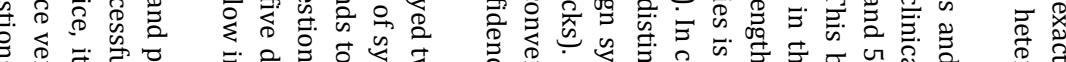

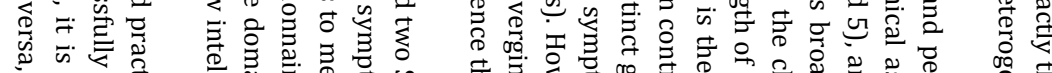

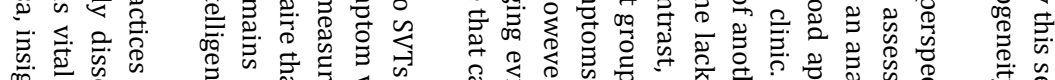

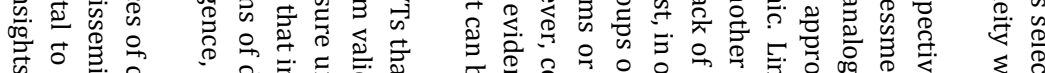

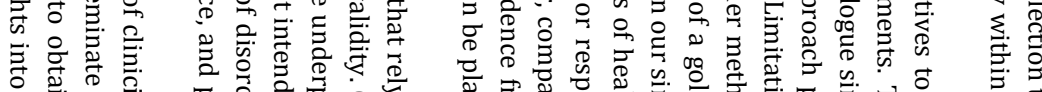

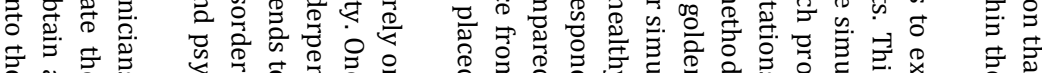

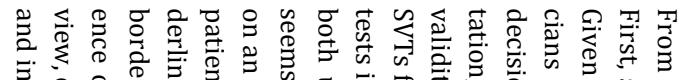

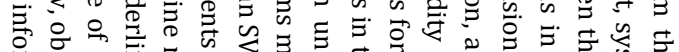

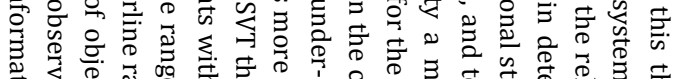

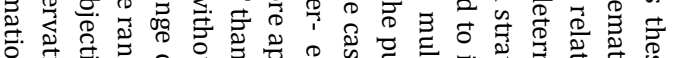

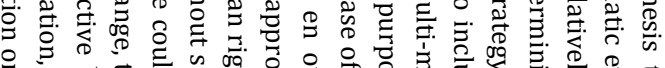

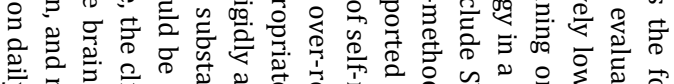

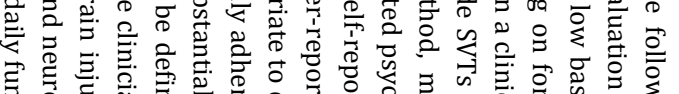

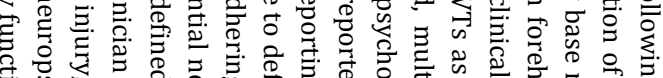
.0.

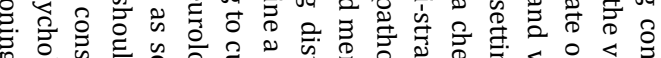

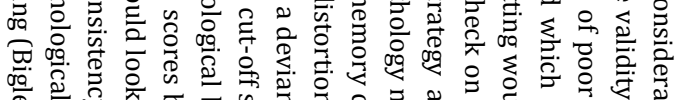

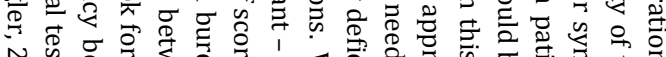

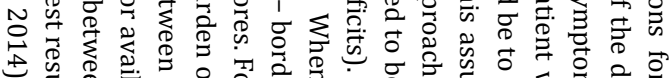

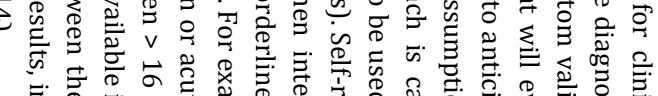

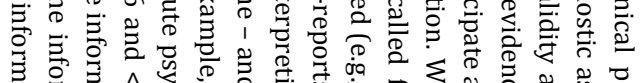

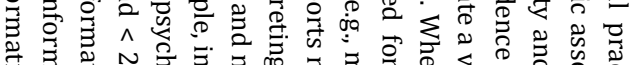

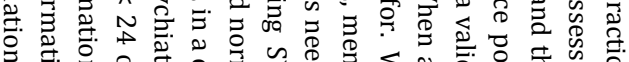

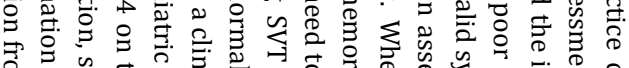

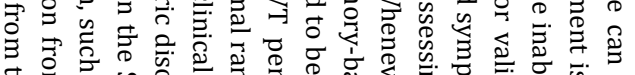

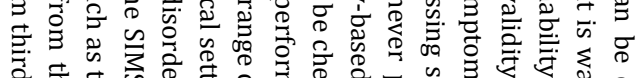

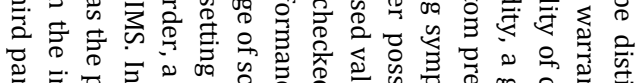

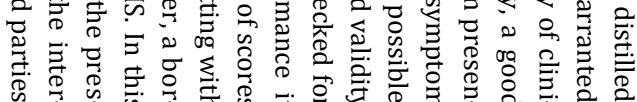

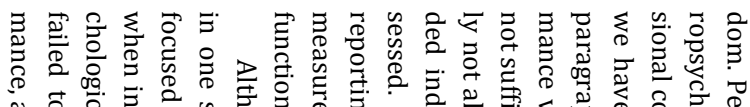

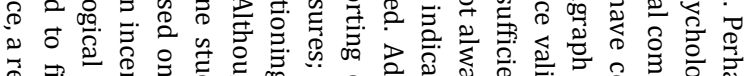

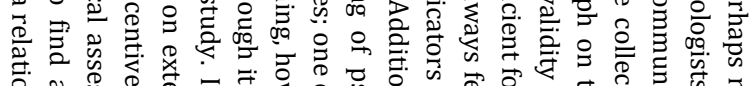

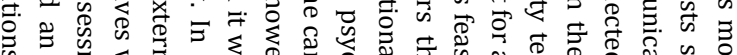

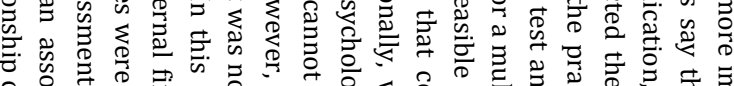

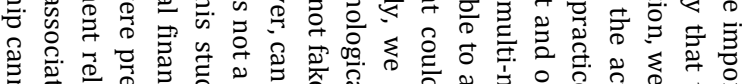

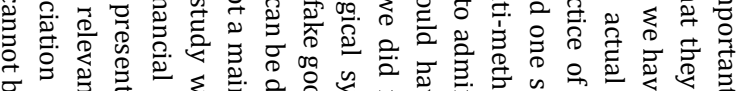

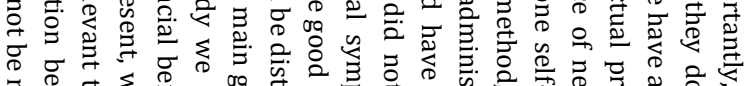

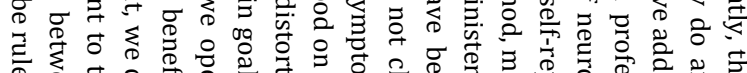

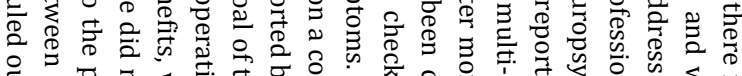

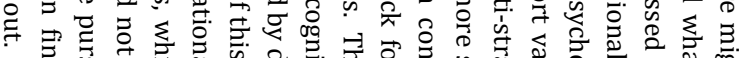

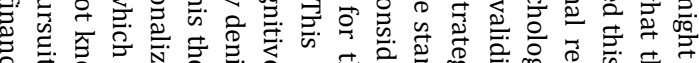

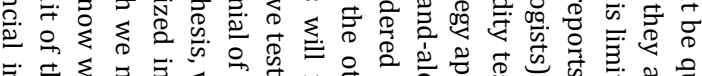

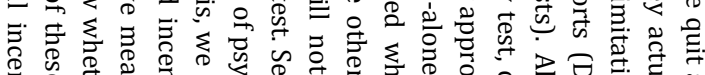

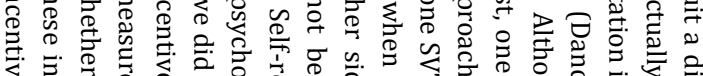

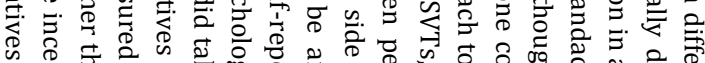

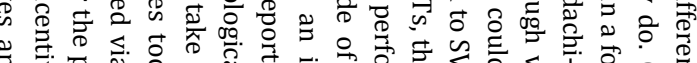

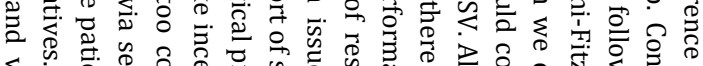

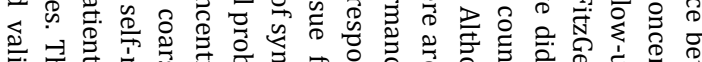

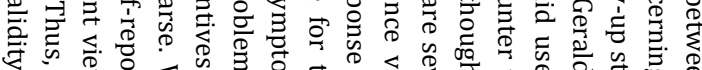
च क्य

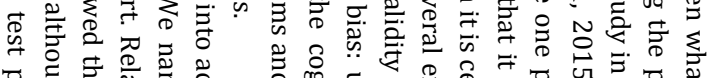

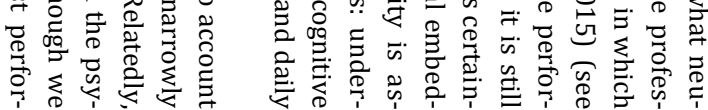




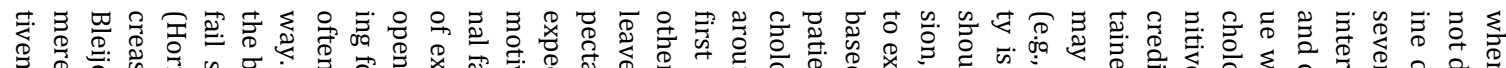

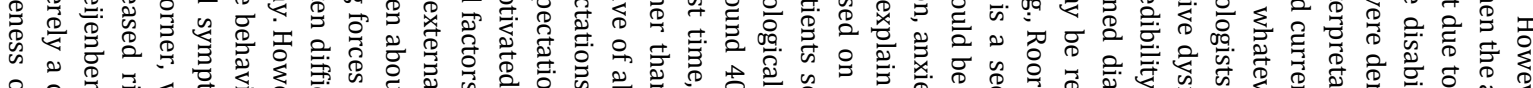

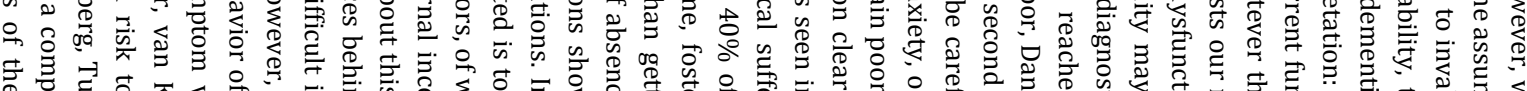

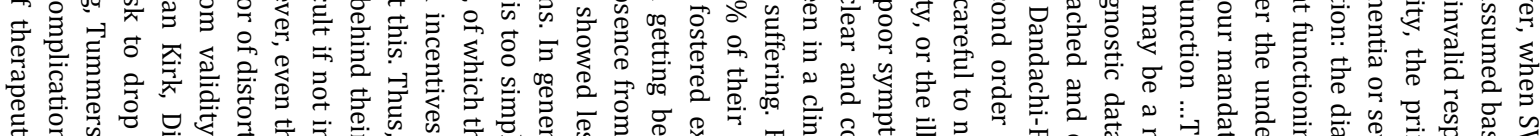

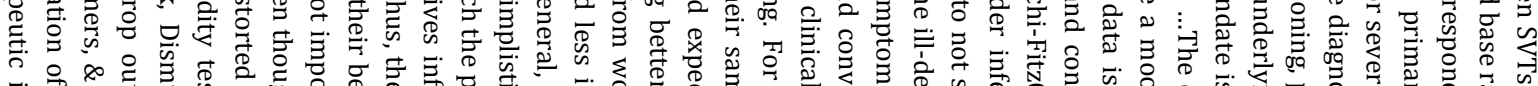

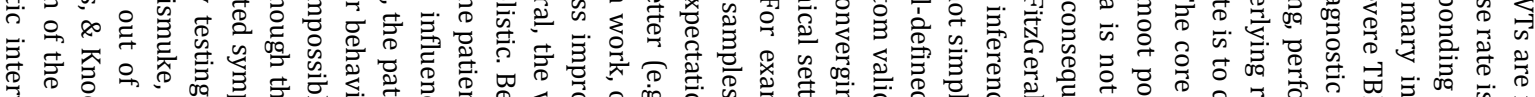

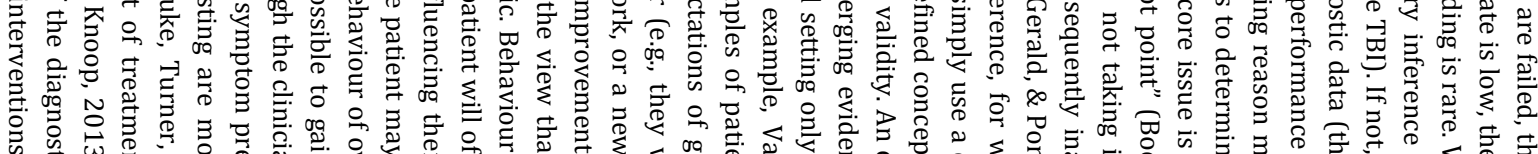

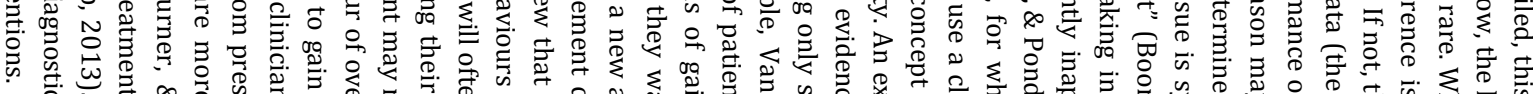

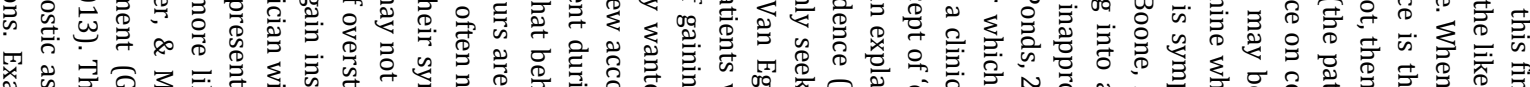

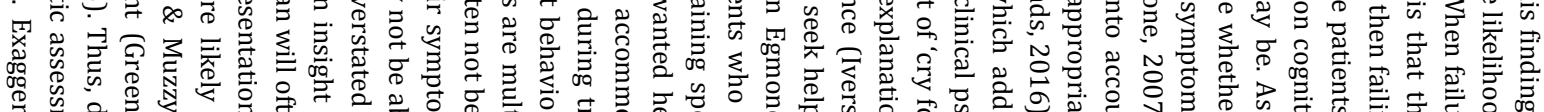
尊纪

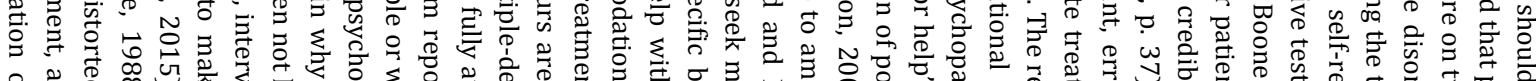

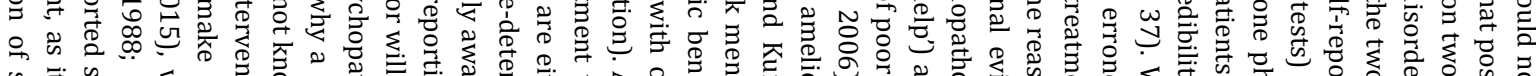

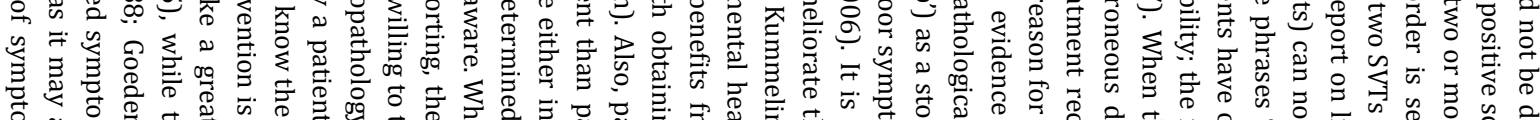

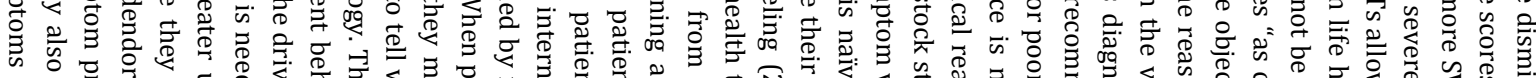

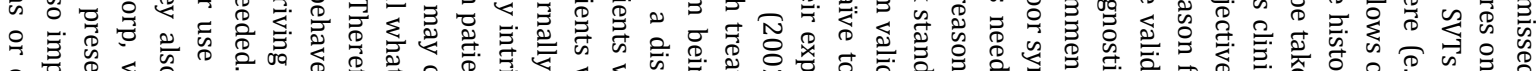

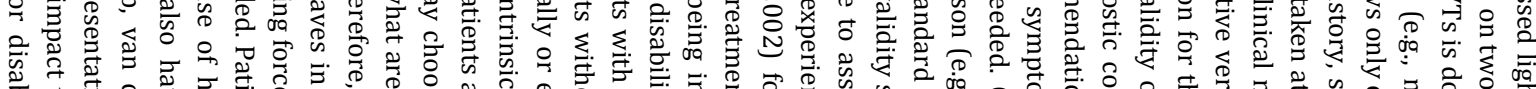

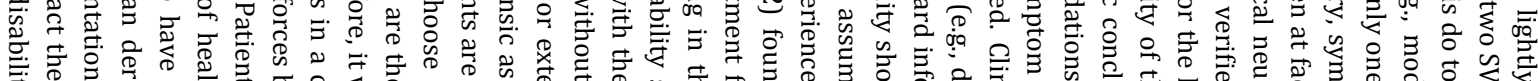

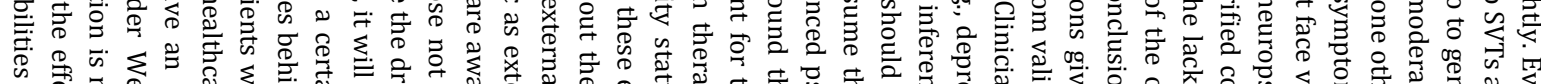

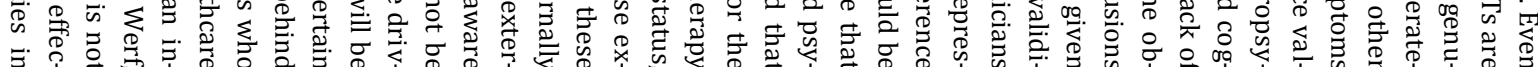

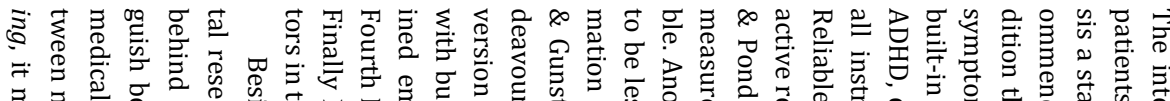

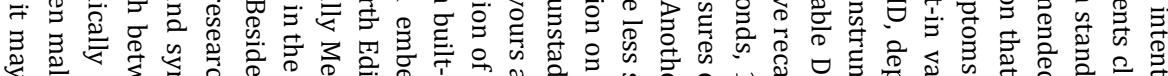

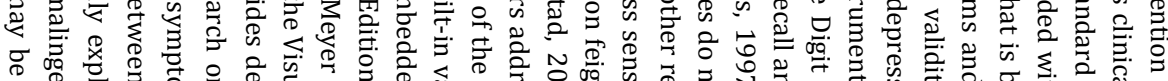

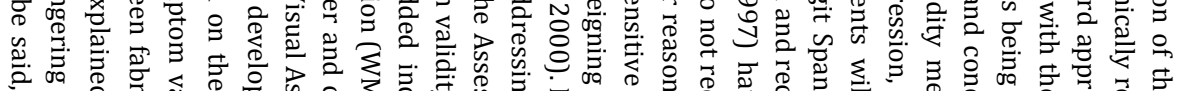

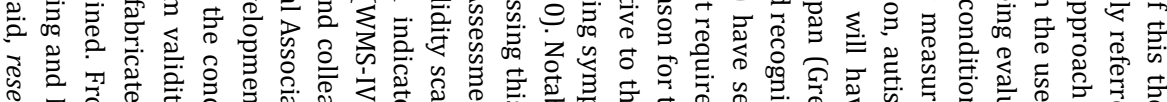

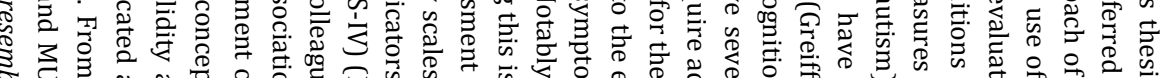

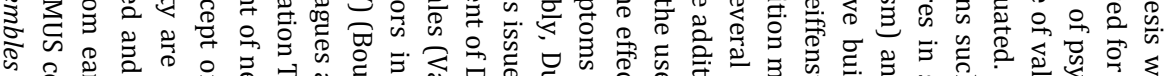

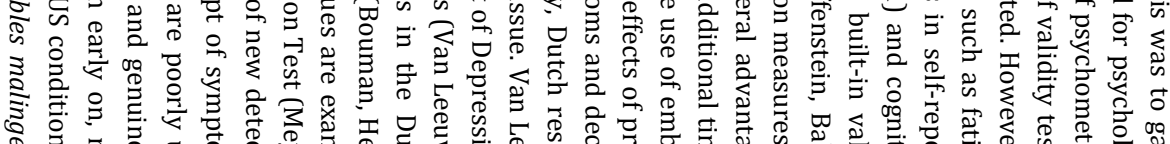

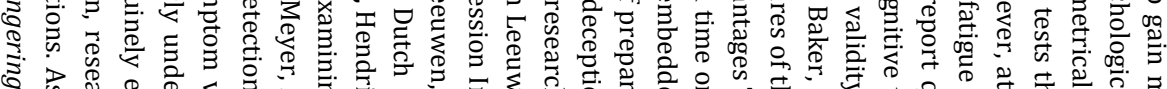

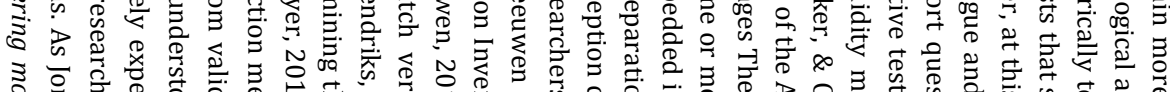

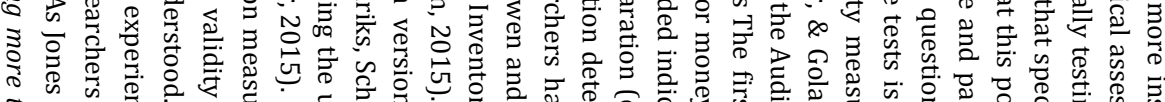

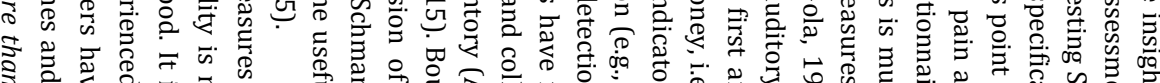

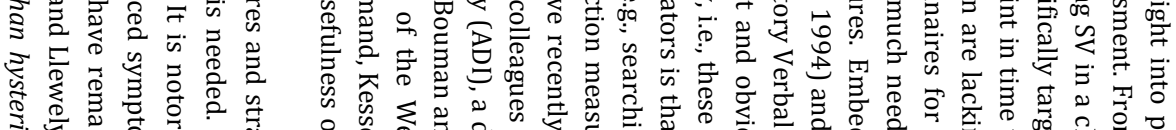

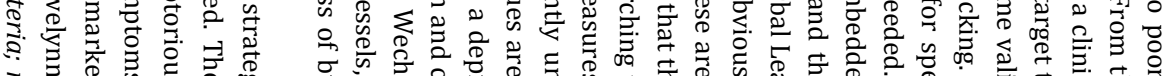

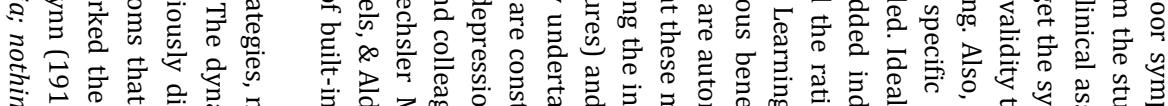
蛋

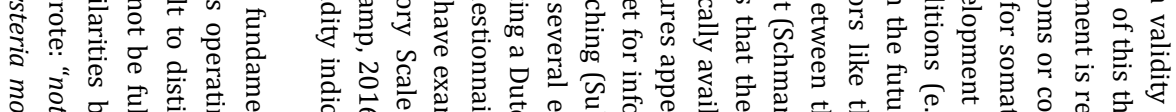

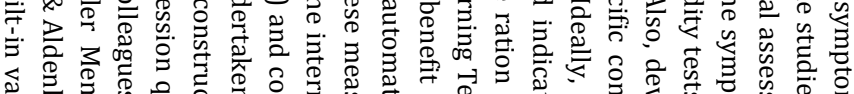

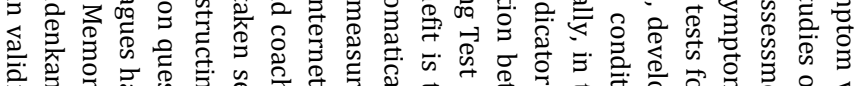
竞

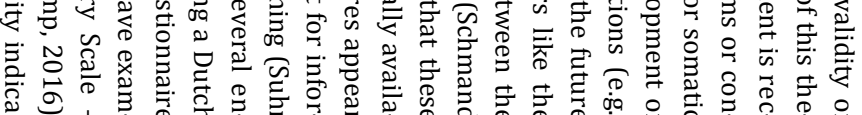

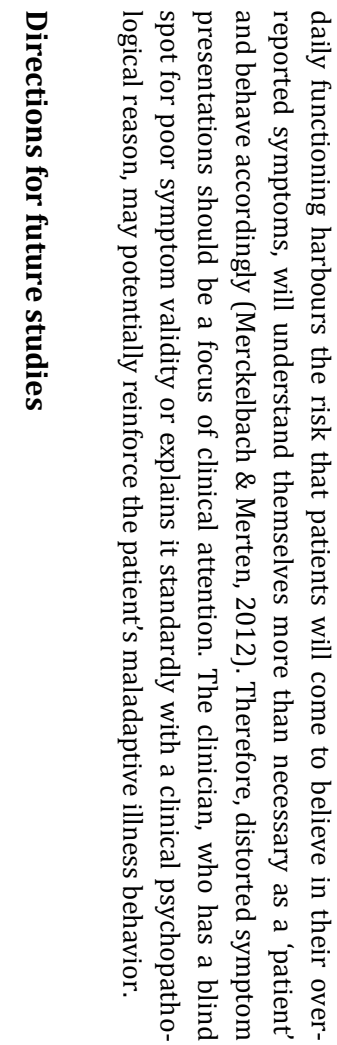




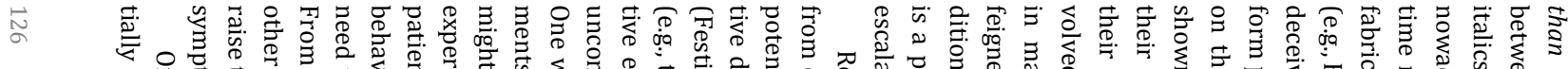

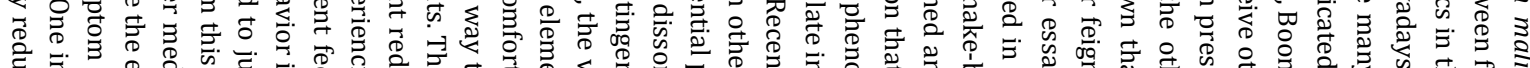

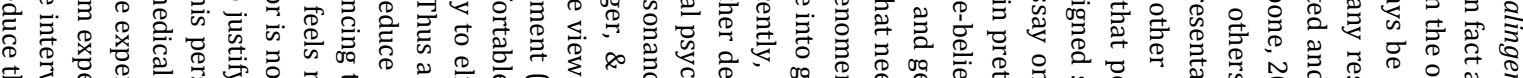

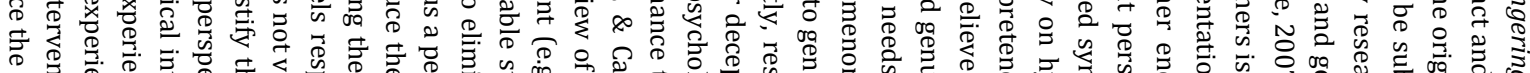

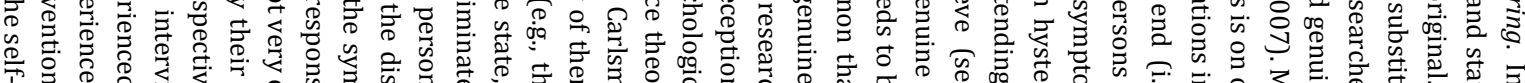

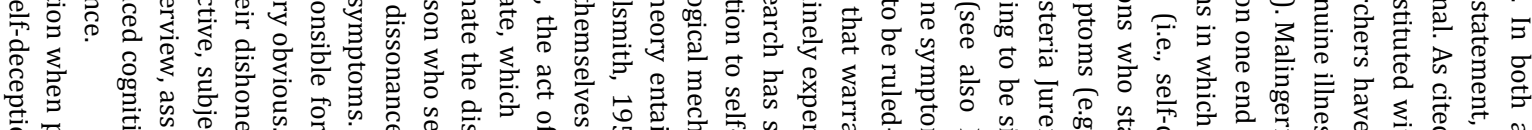

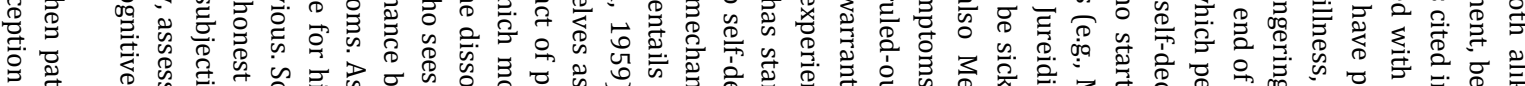

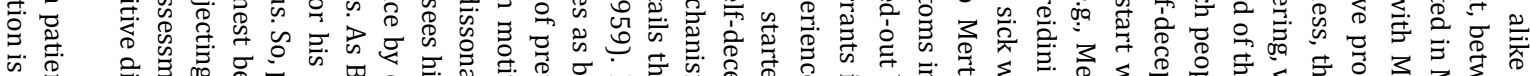

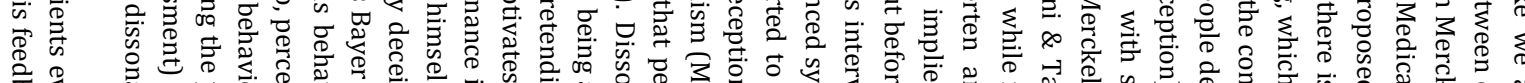

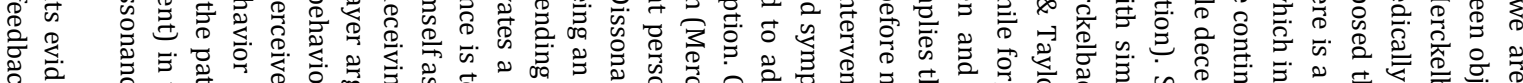

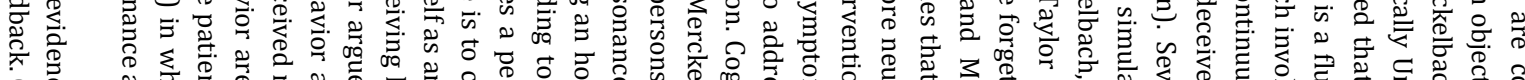

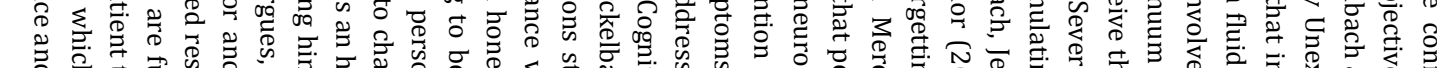

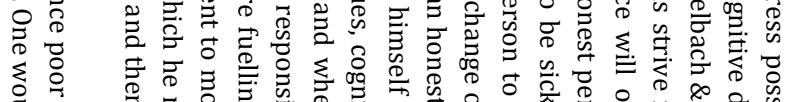

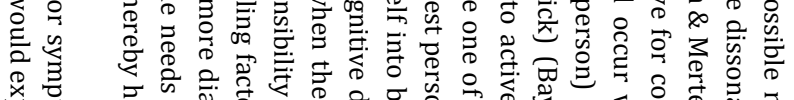

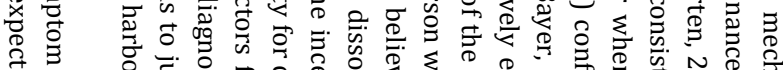
考

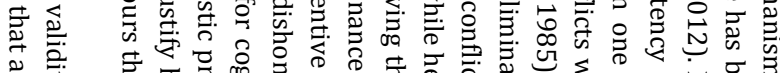

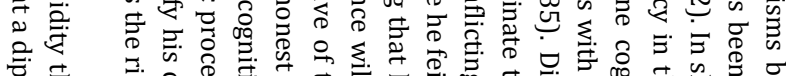

苛声 志

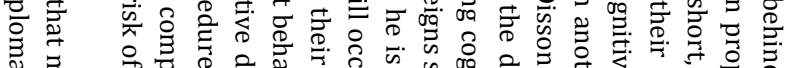

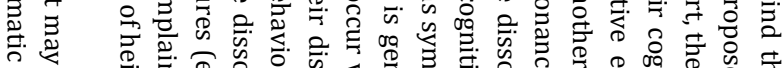

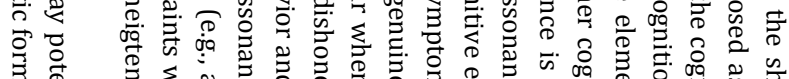

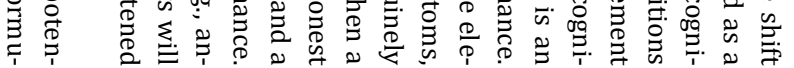
○

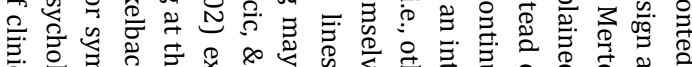

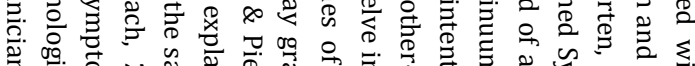

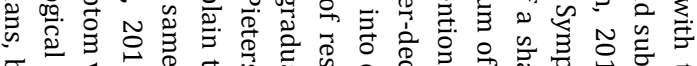

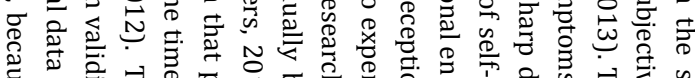

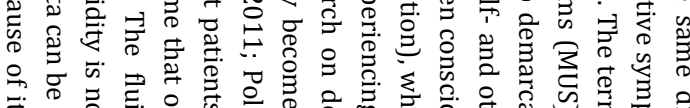

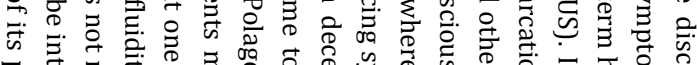

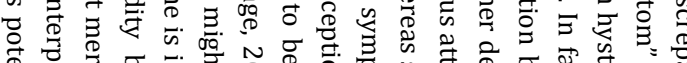

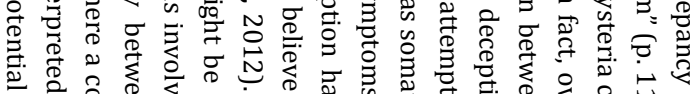

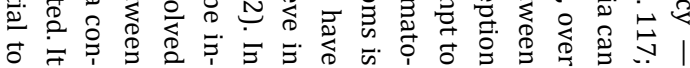

马y 式.

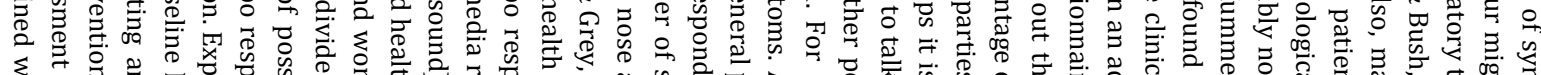

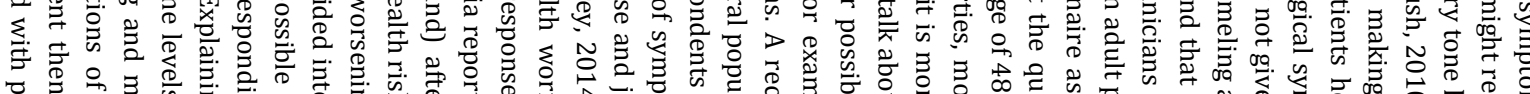

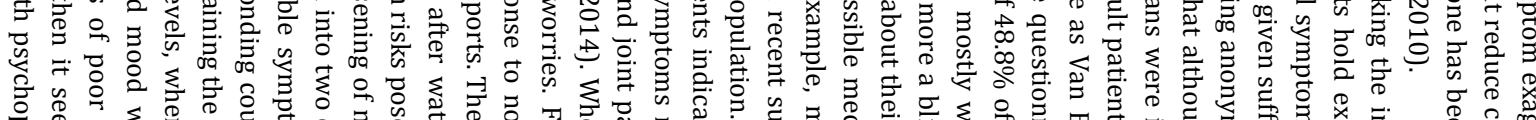

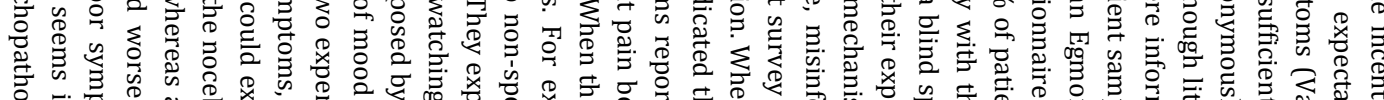

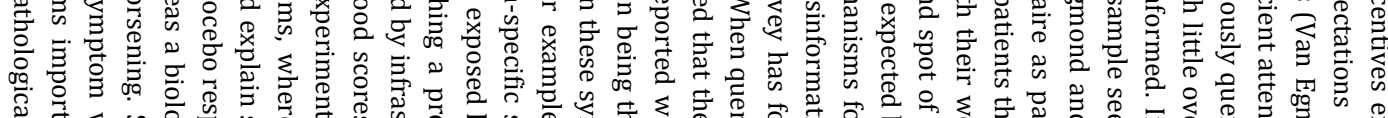

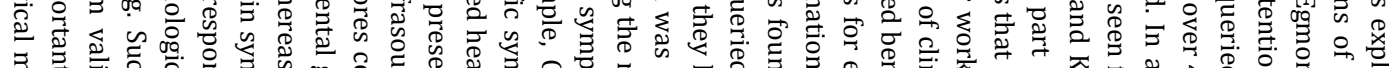

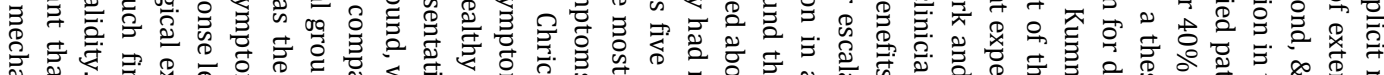

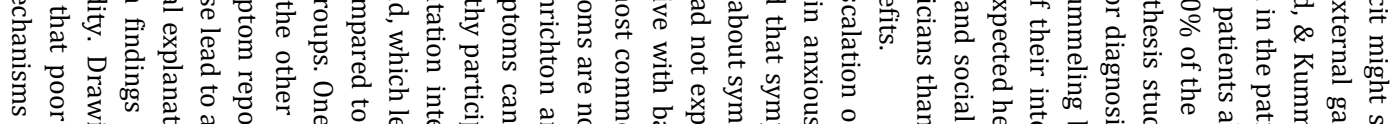

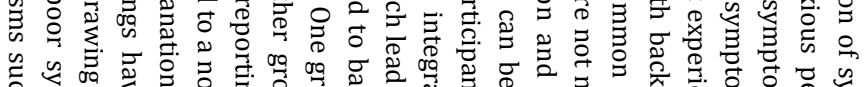

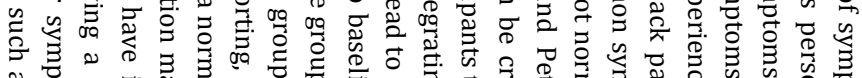

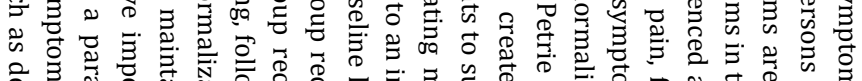

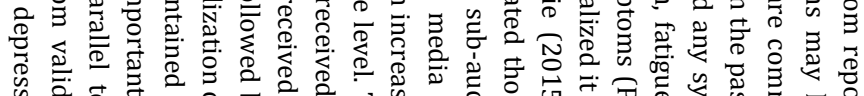

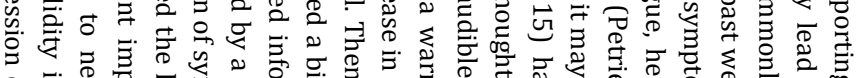

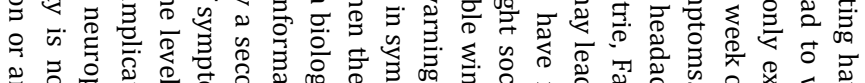

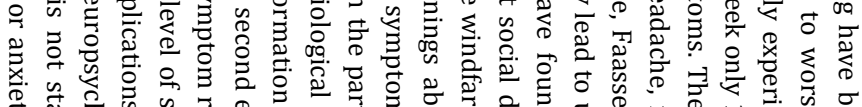

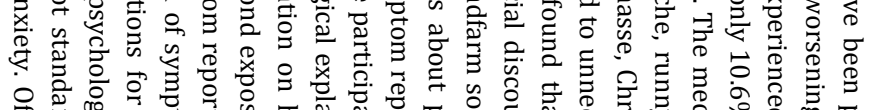

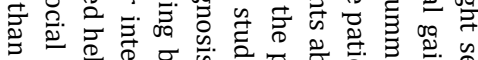

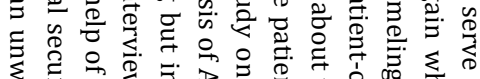

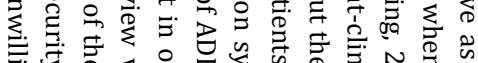

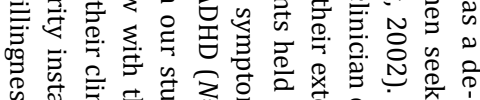

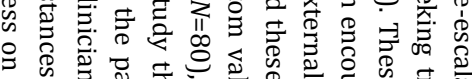

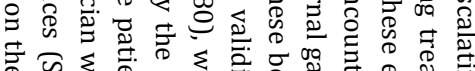

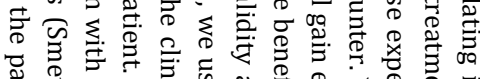

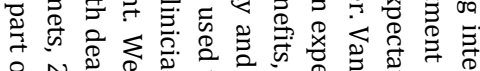

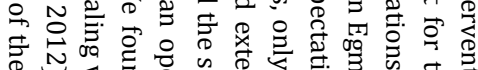

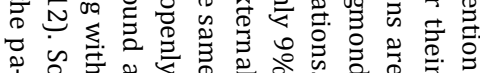

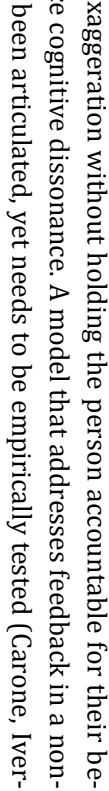




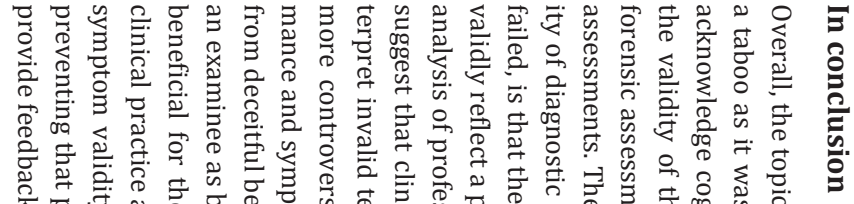

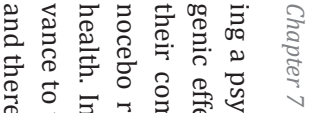

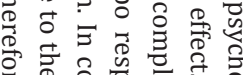

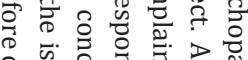

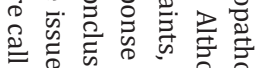

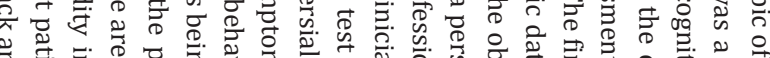

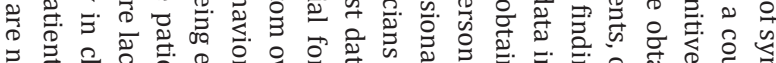

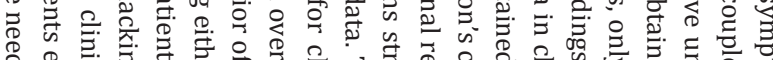

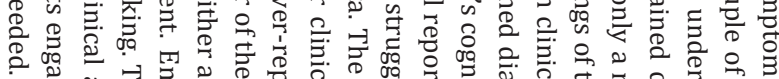
ơ

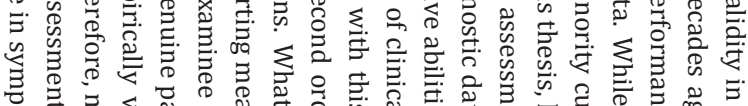

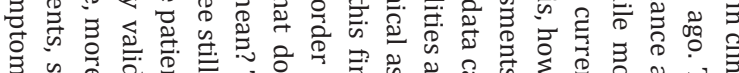

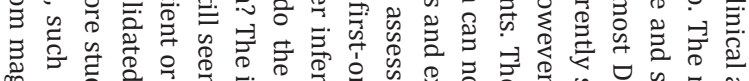

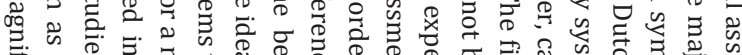

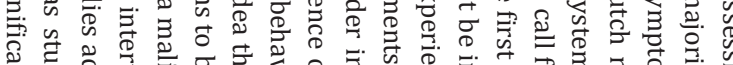

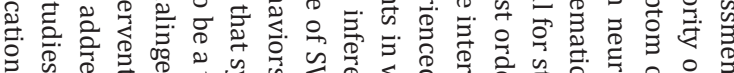

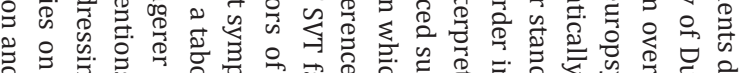

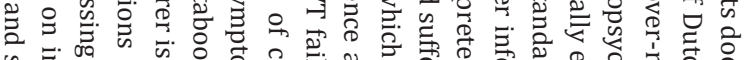

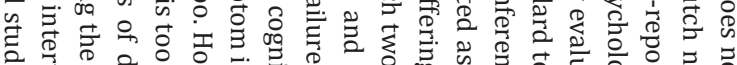
家.

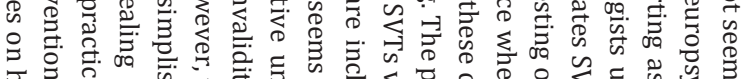

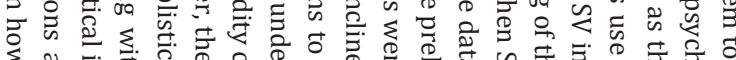

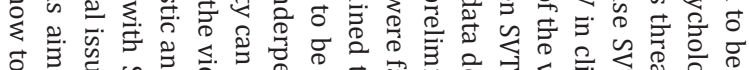

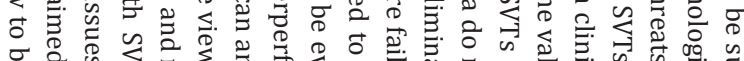

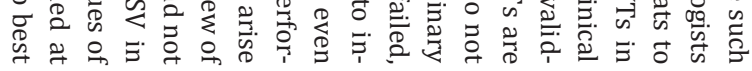

के

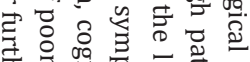

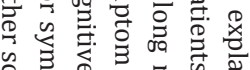

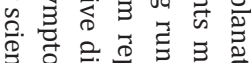

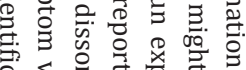
ते

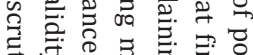

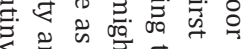

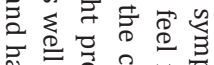

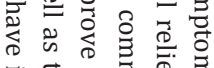

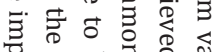

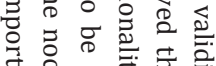

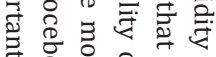
다유 Е.

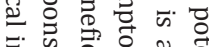

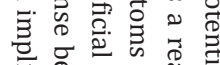

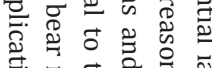

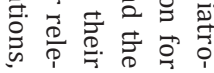

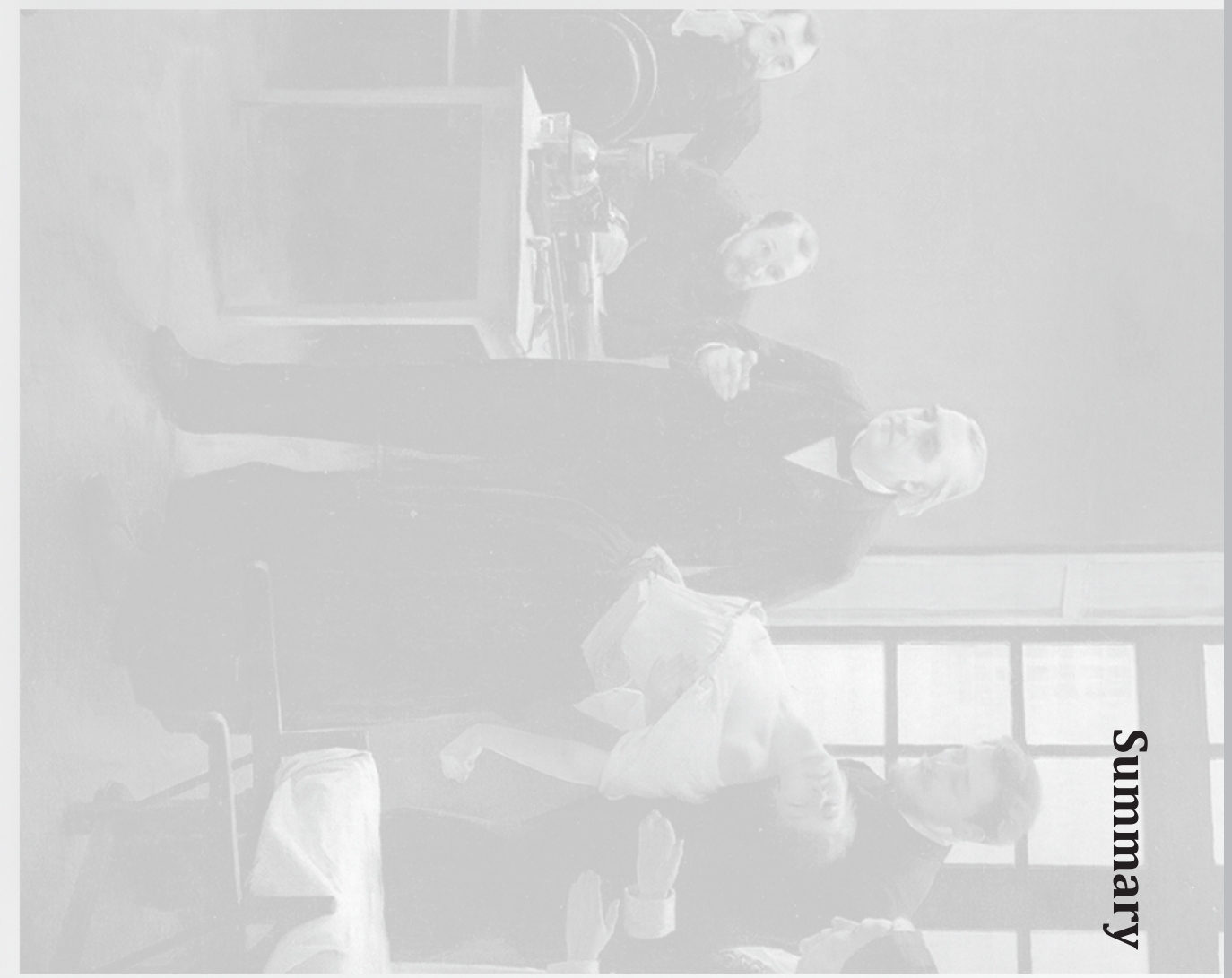




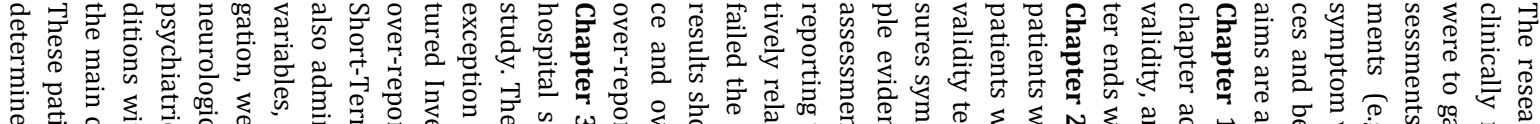

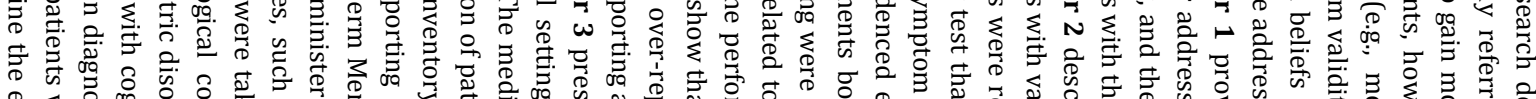

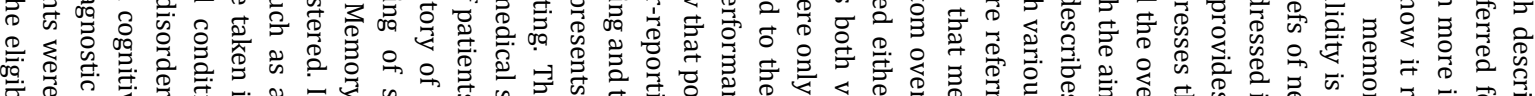

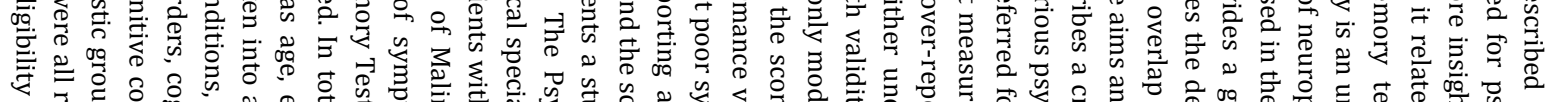

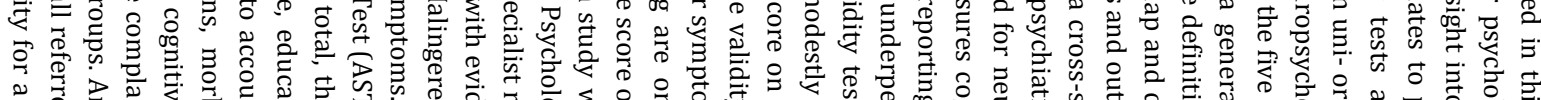

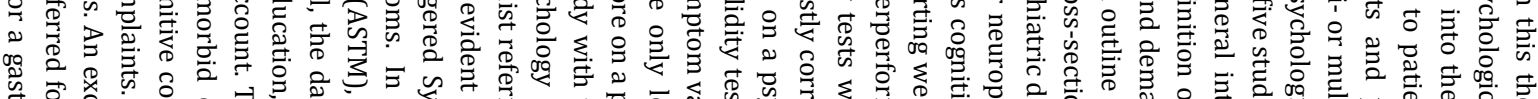

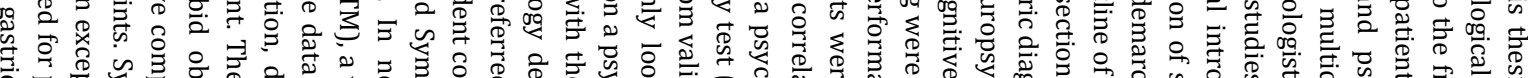

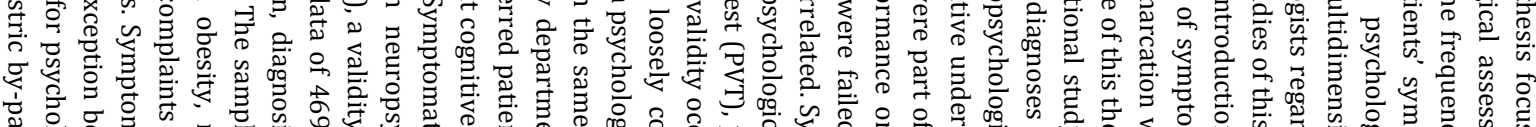

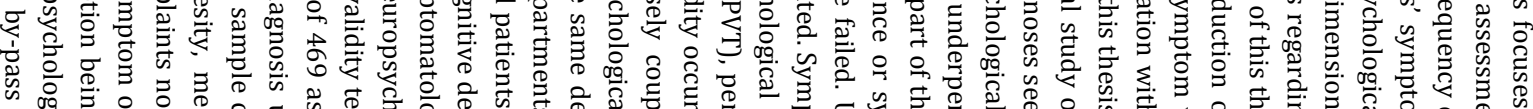

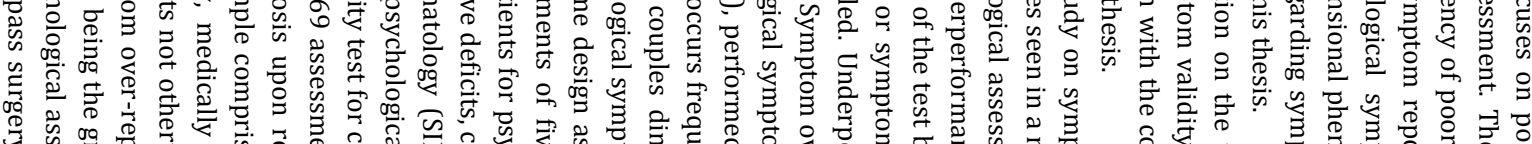

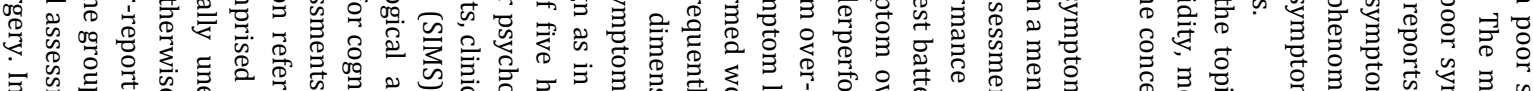

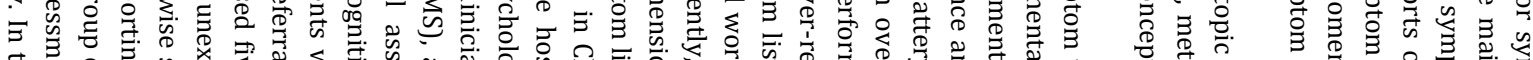

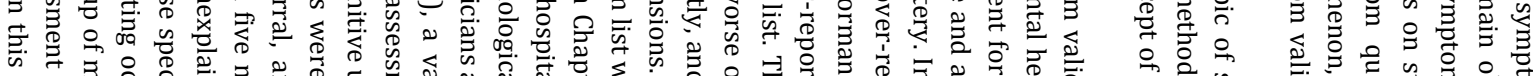

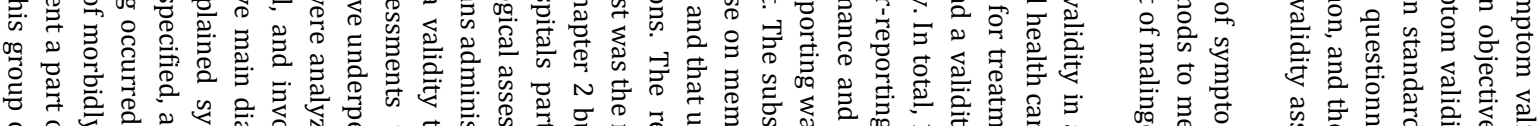

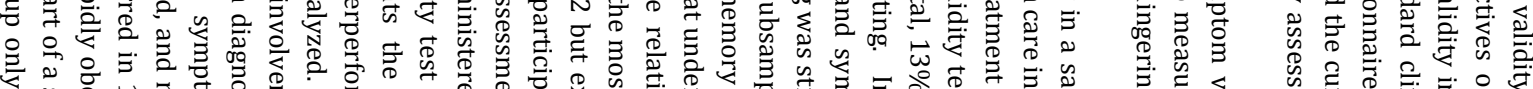

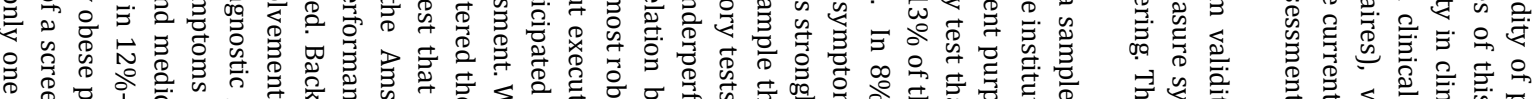

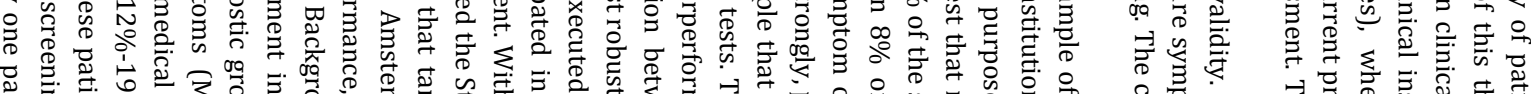

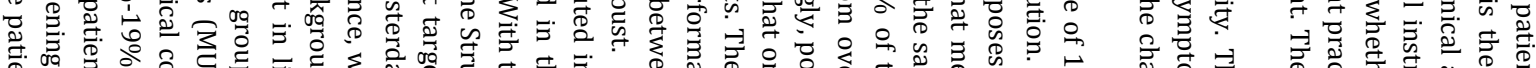

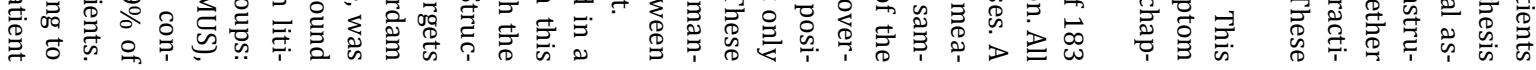

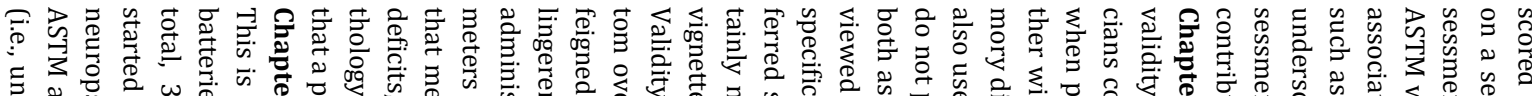

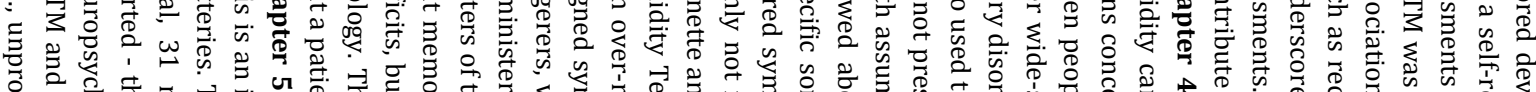

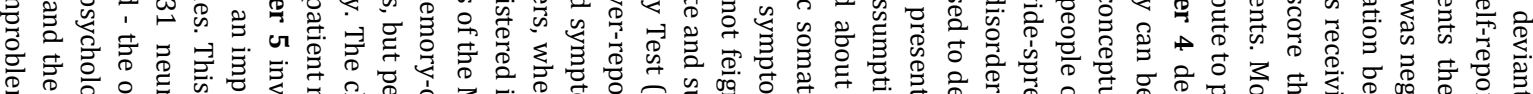

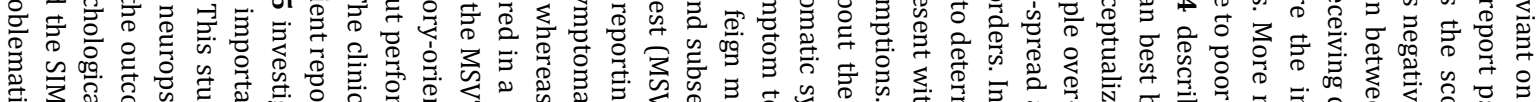

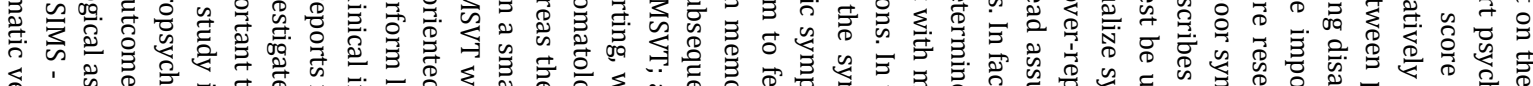

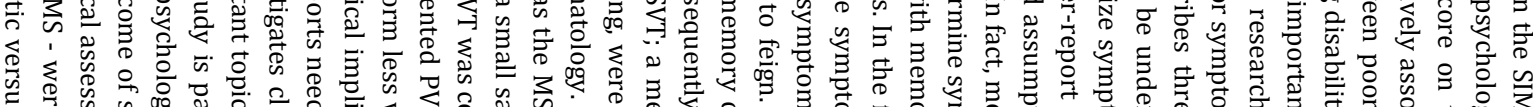

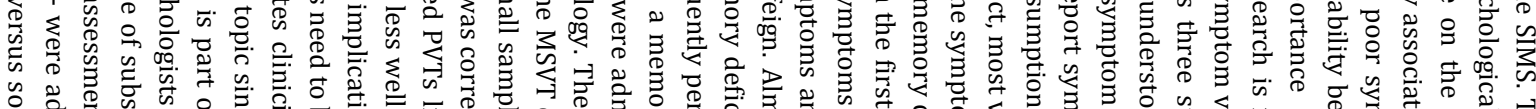

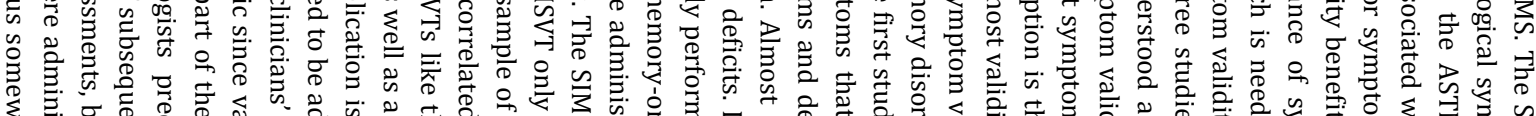

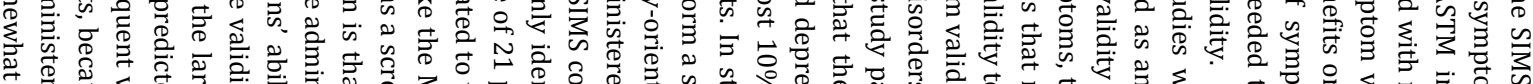

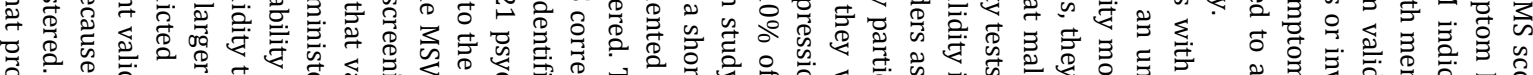

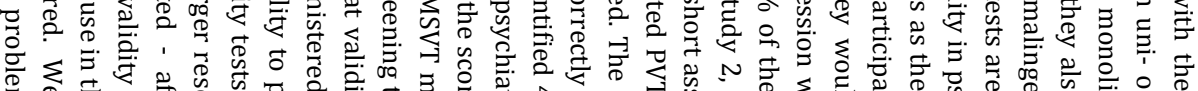

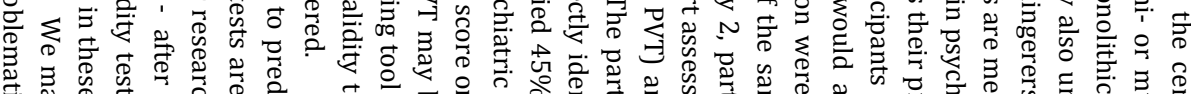

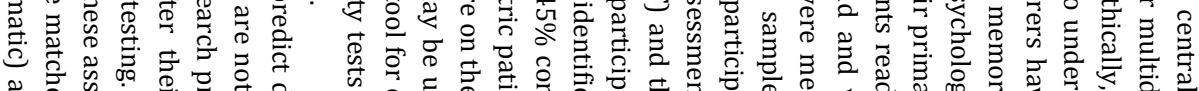

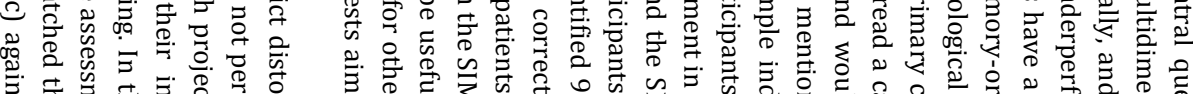

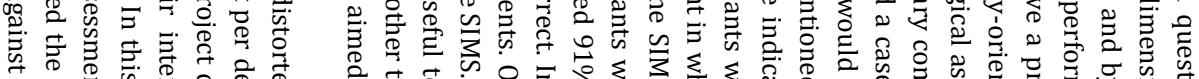

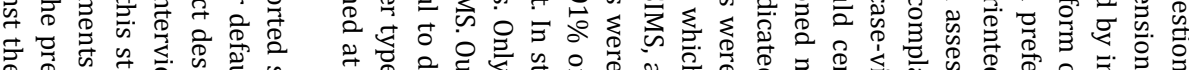

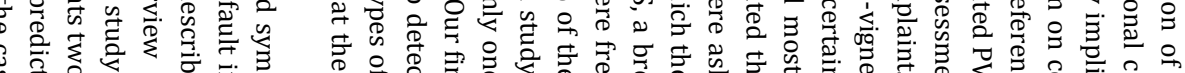

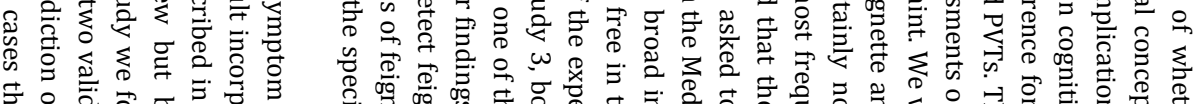

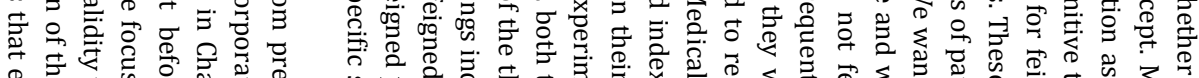

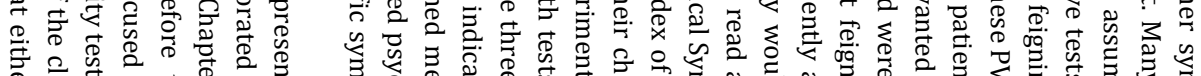

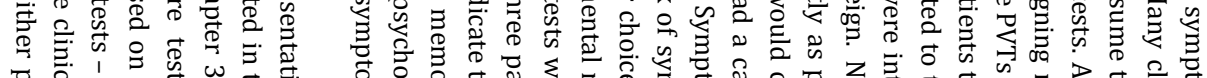
嵌

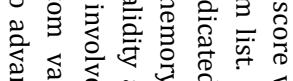

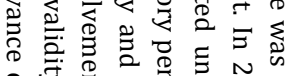

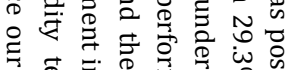

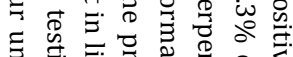

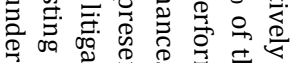

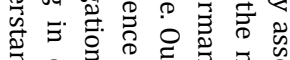

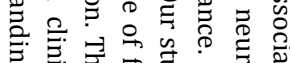

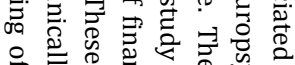

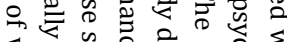

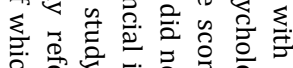

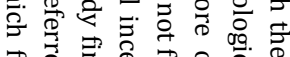

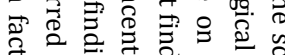

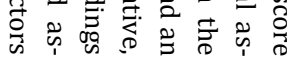




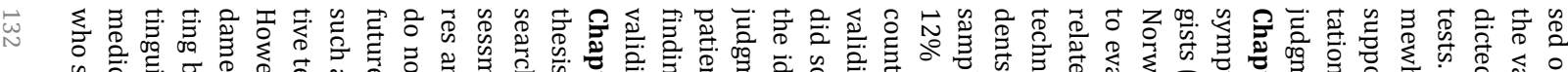

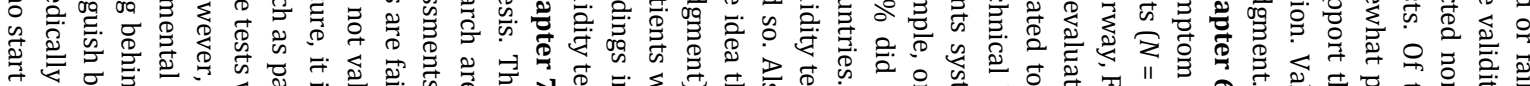

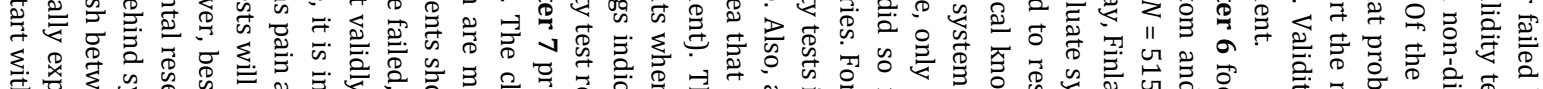

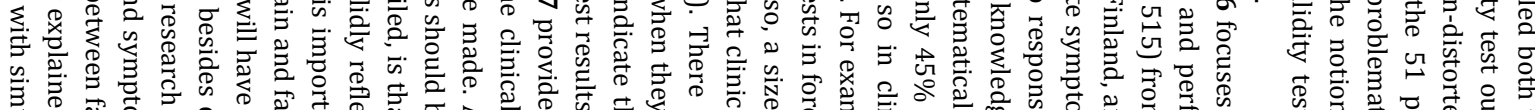

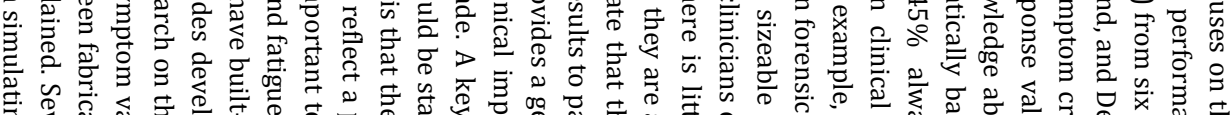

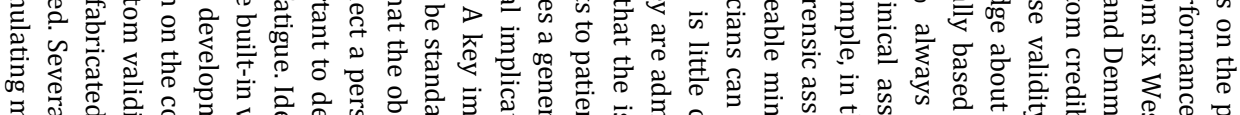

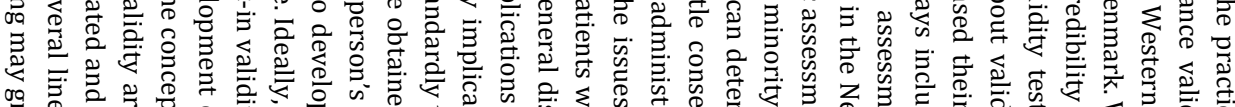

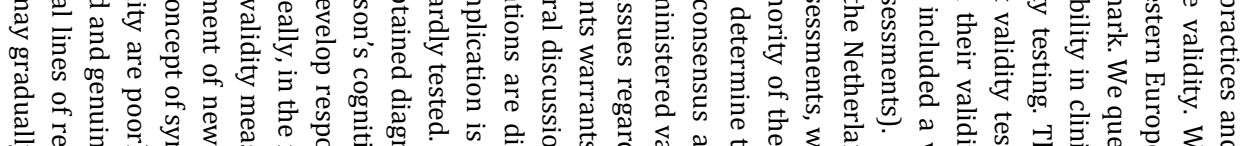

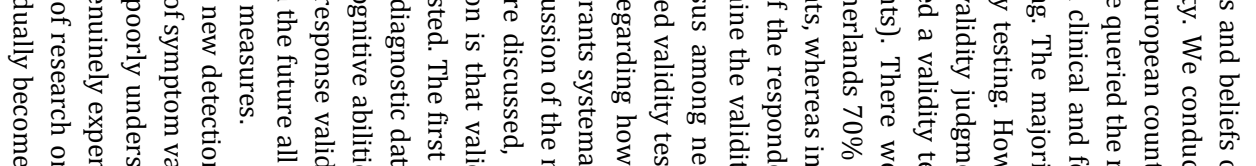

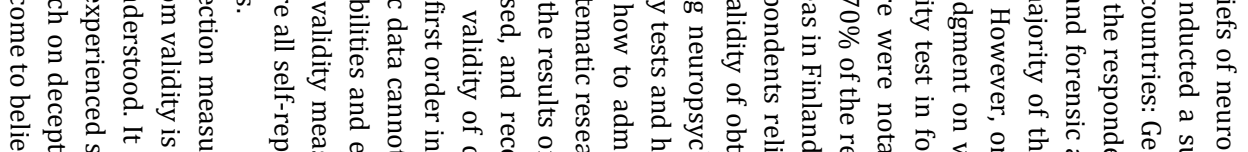

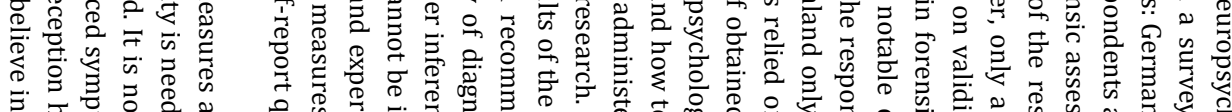

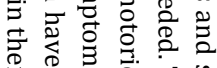
․ क.

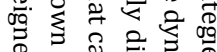

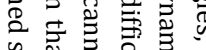

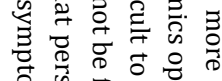

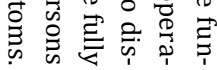

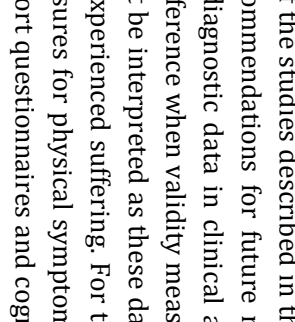

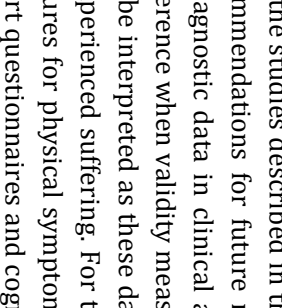

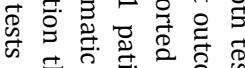

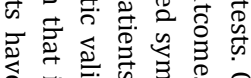

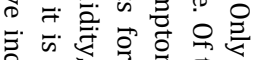

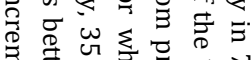

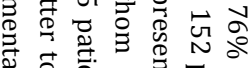

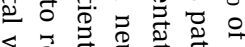

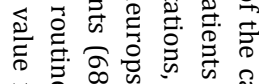

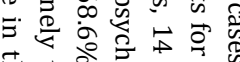

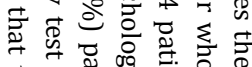

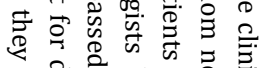

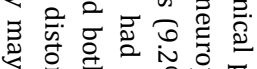

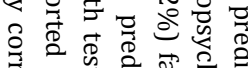
की

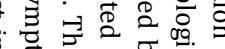

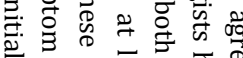

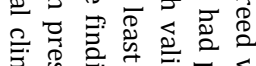
ㅋ.ㄹ. 


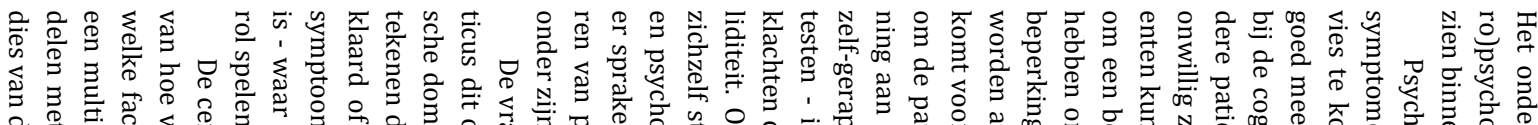

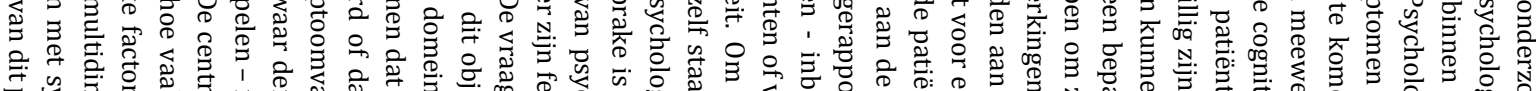

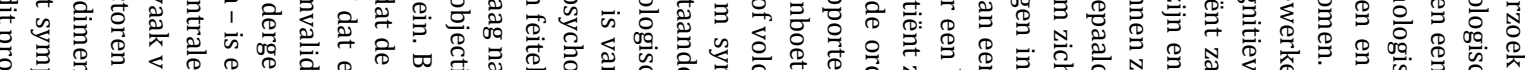

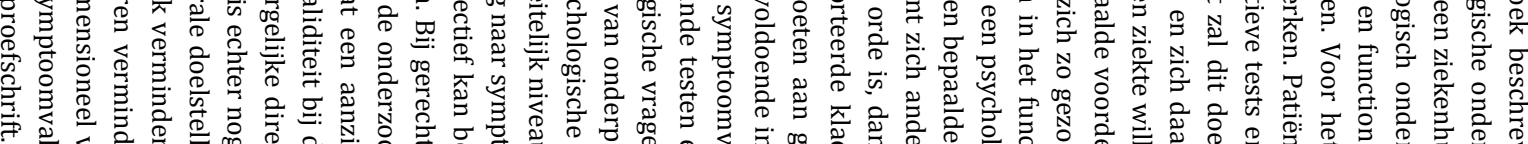

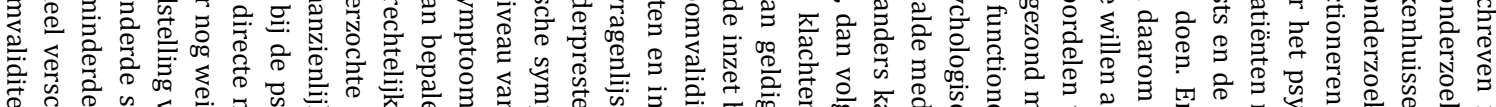

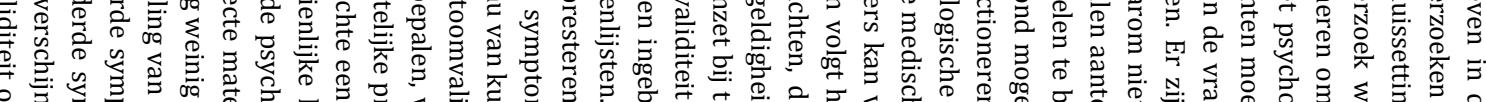

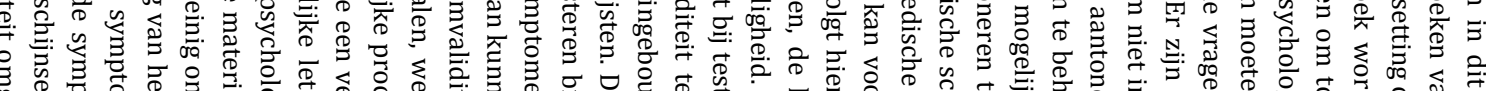

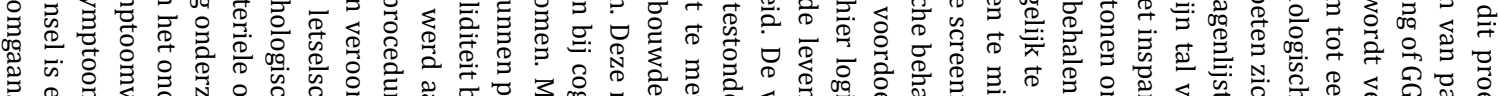

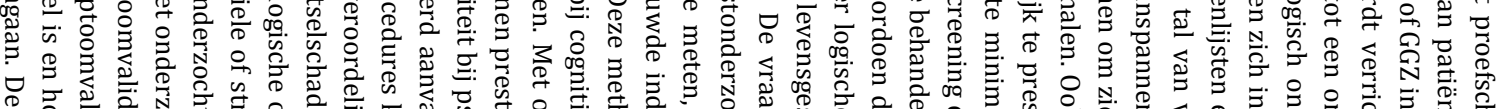

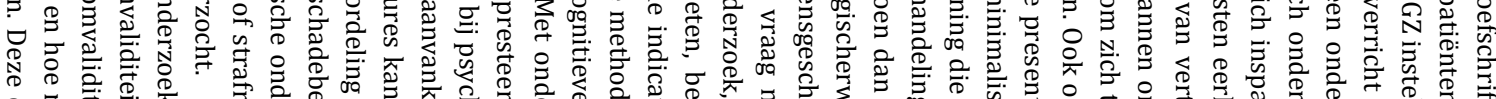

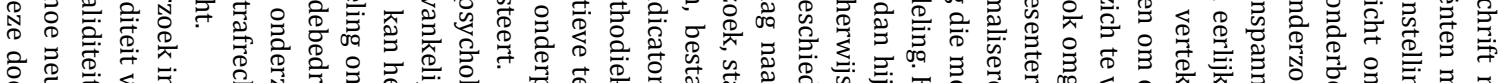

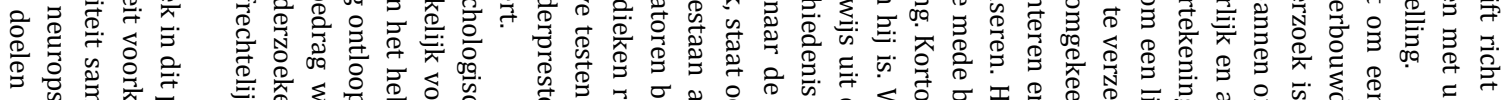

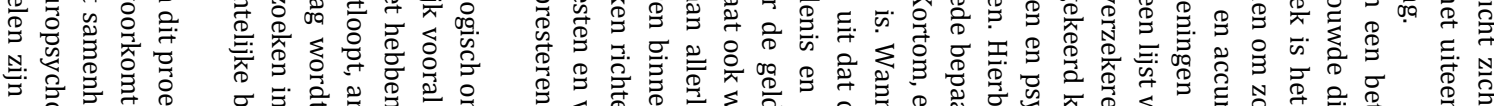

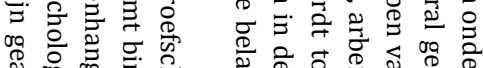

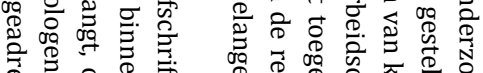

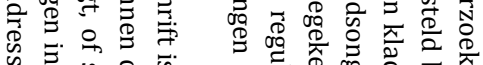

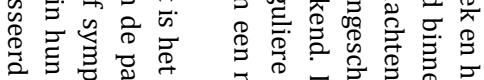

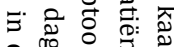

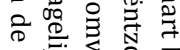

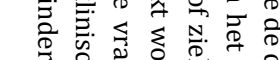
运:

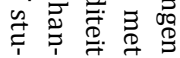

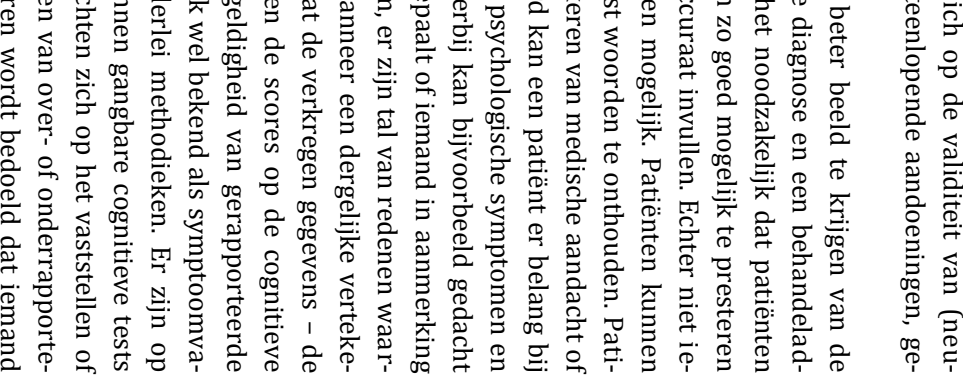

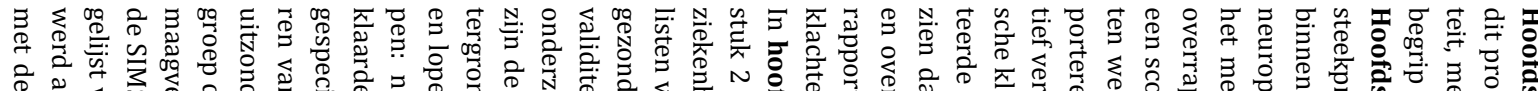

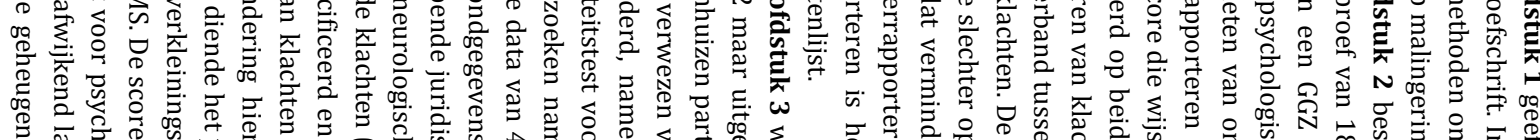

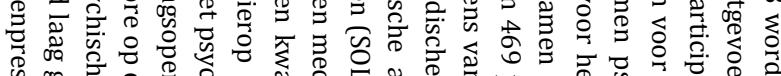

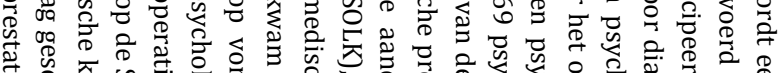

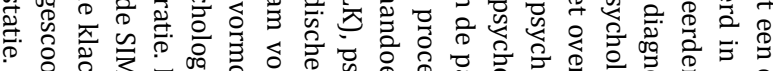

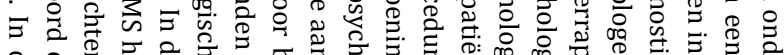

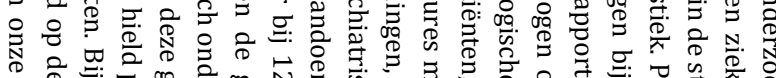

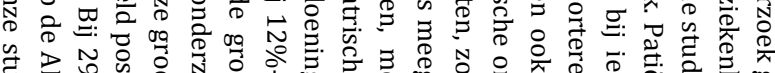

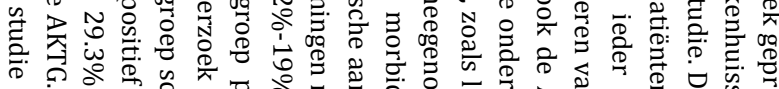

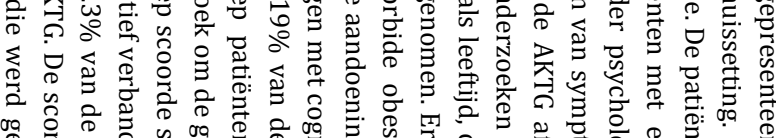
or ô

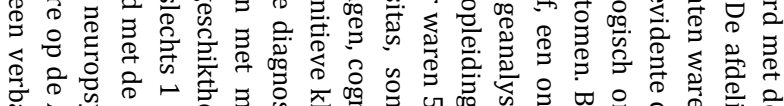

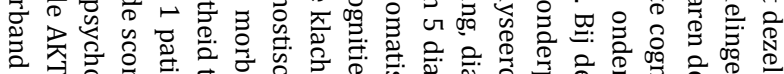
o

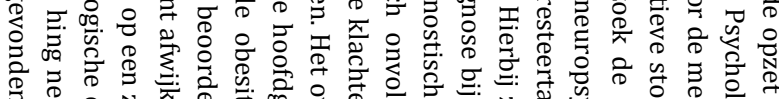

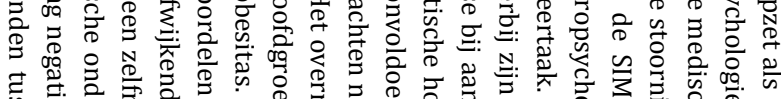

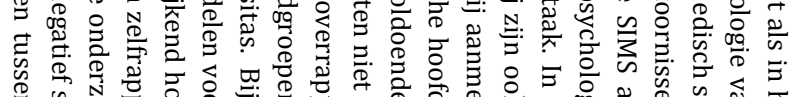

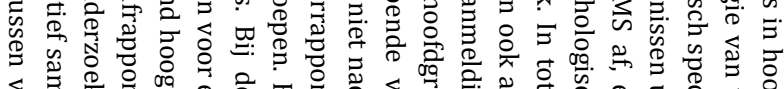

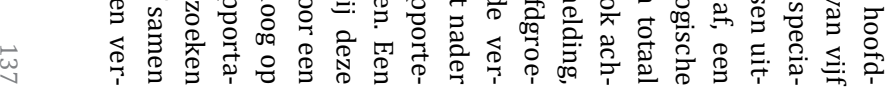

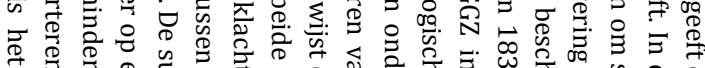

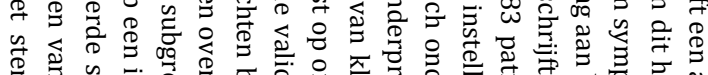

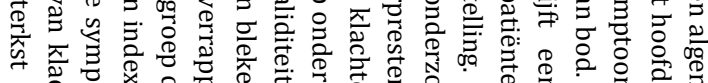

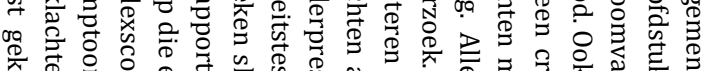

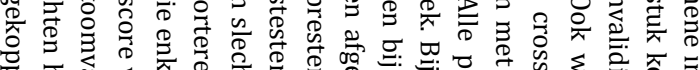

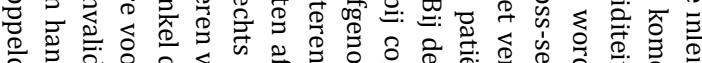

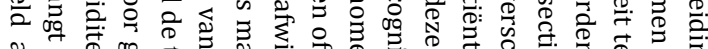

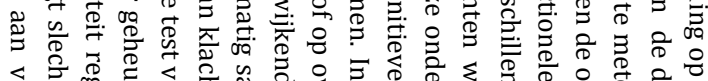

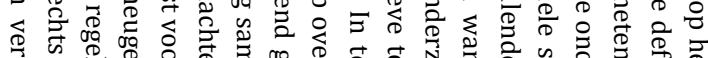

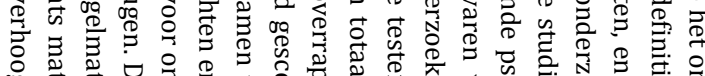

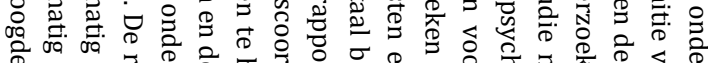

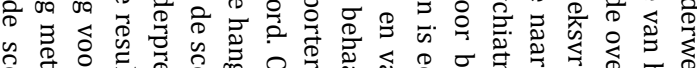

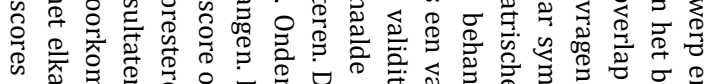
윤

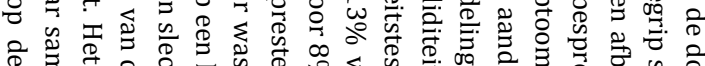

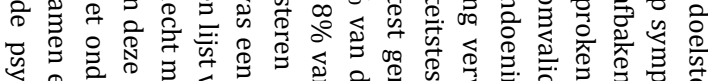

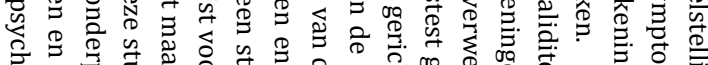

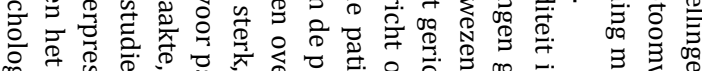

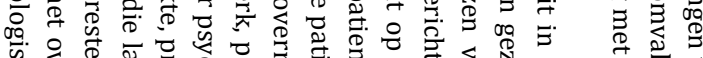

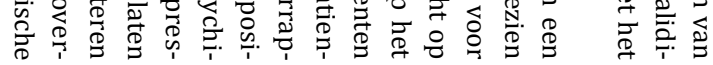




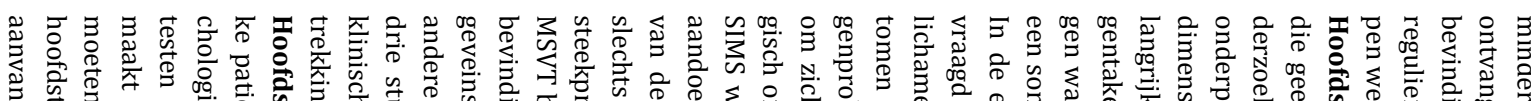

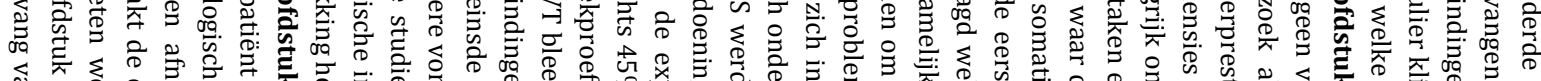

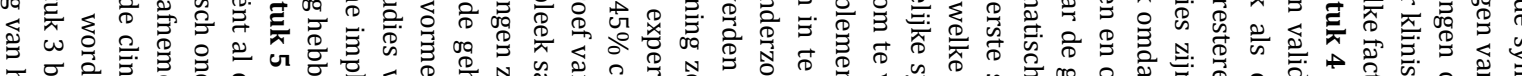

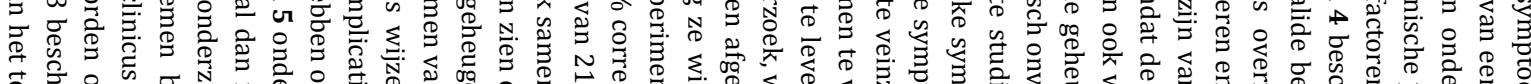

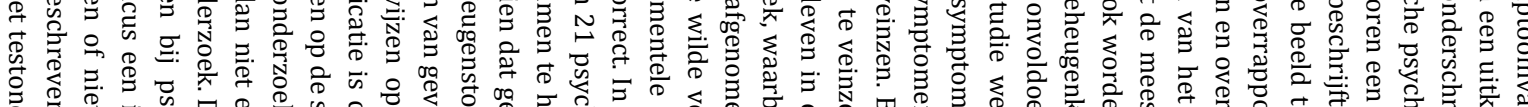

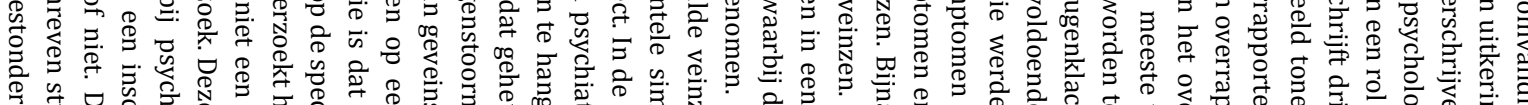

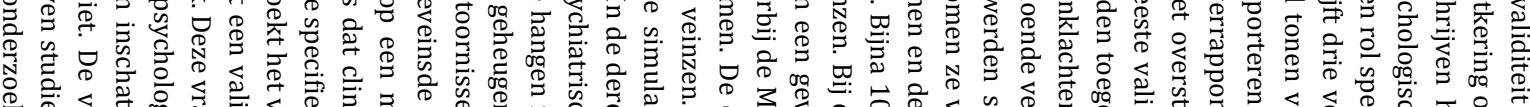

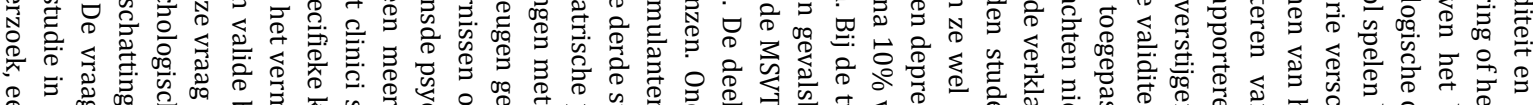

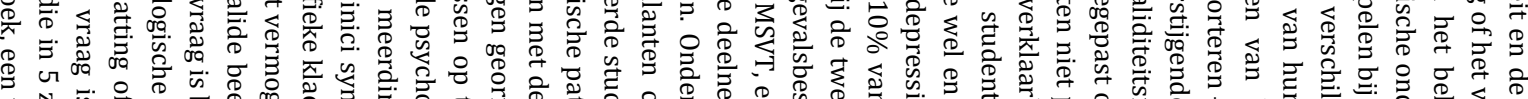

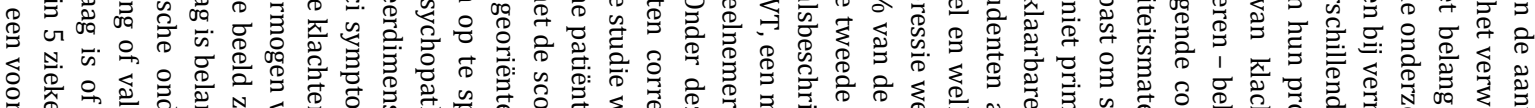

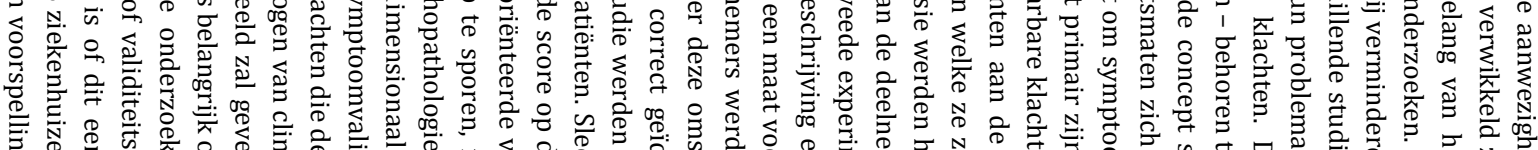

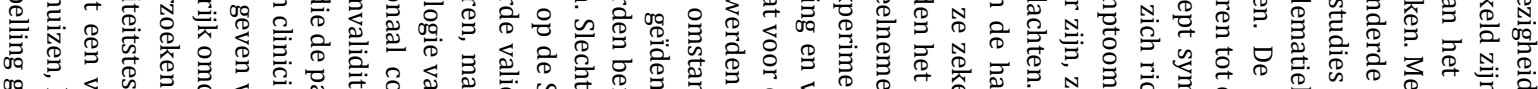

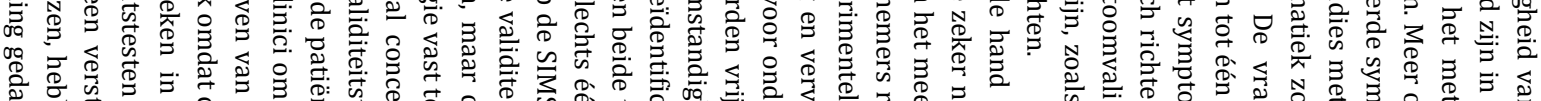

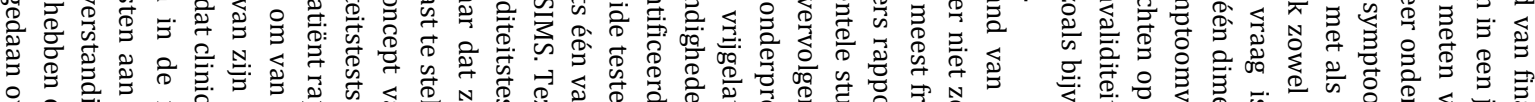

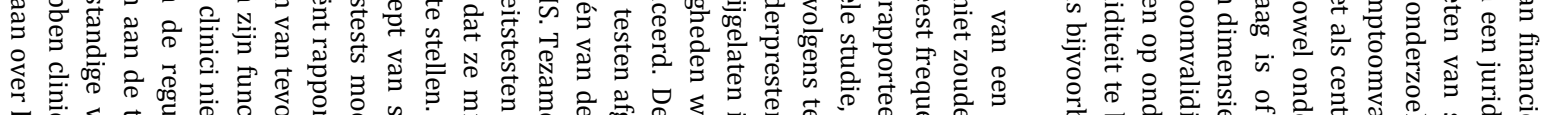

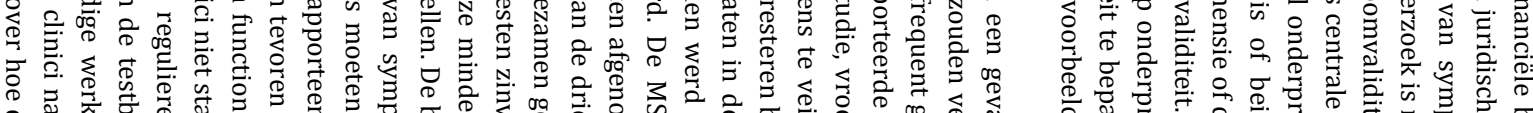

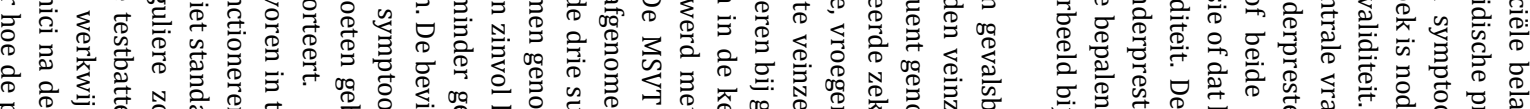

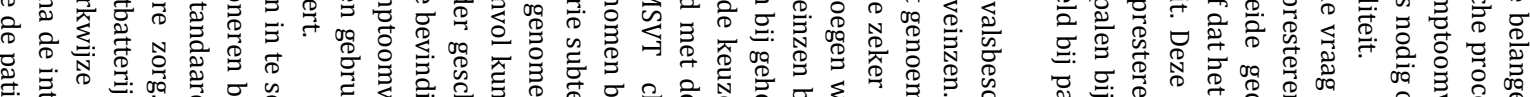

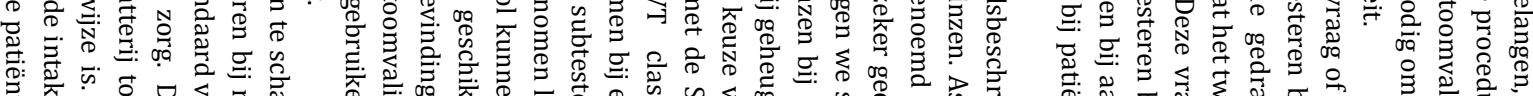

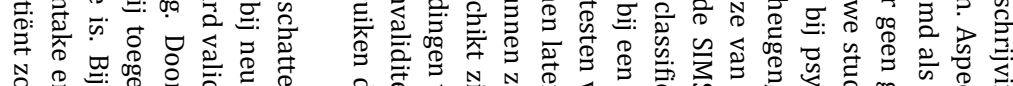

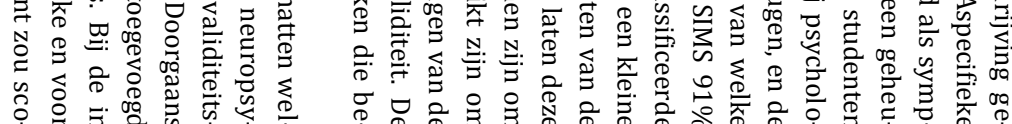

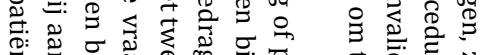

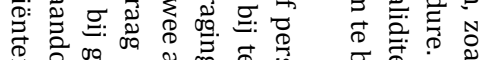
在

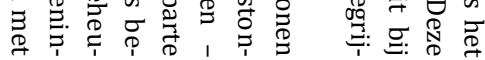

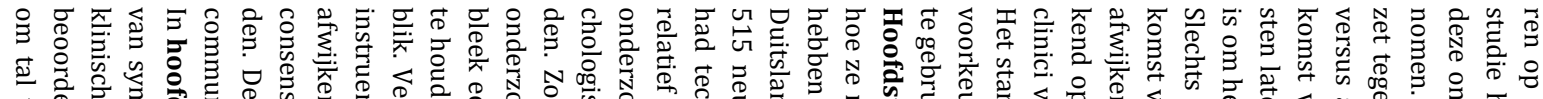

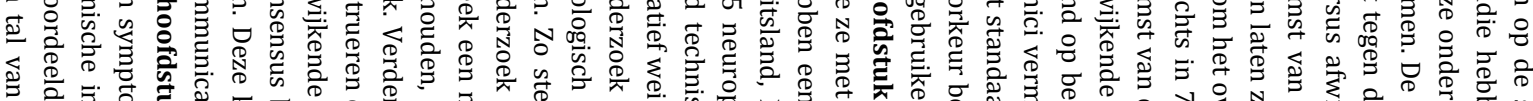

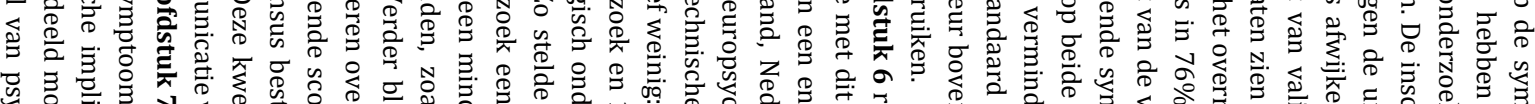

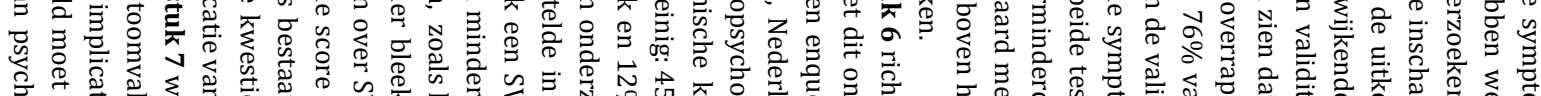

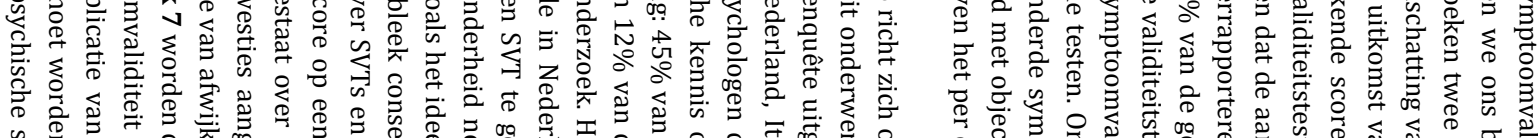

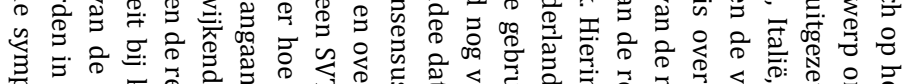

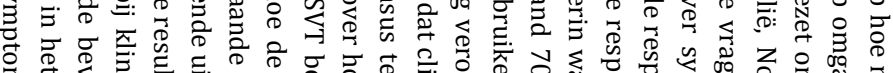

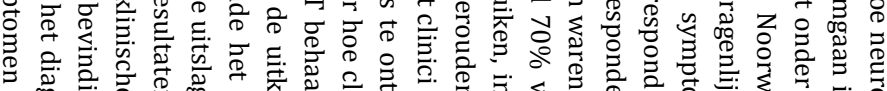

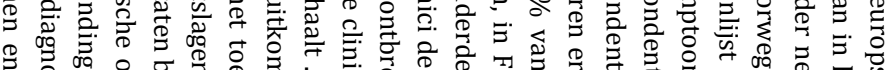

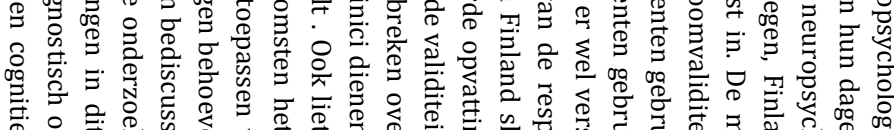

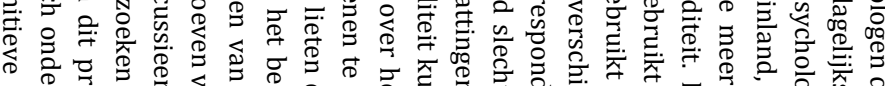

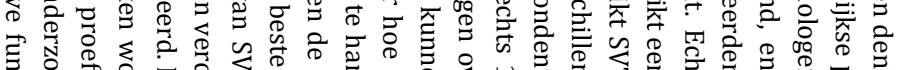

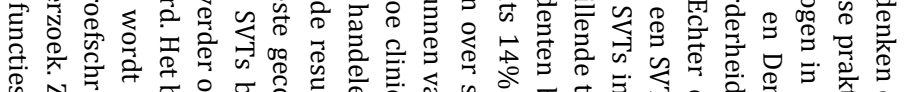

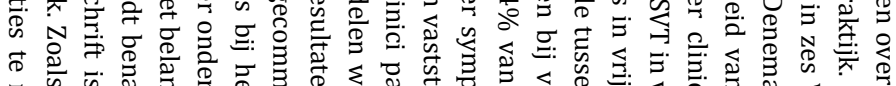

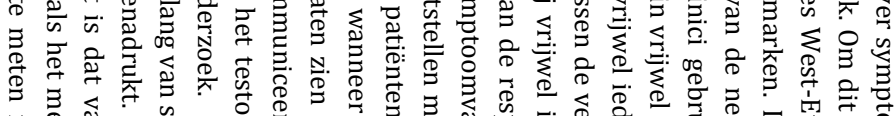

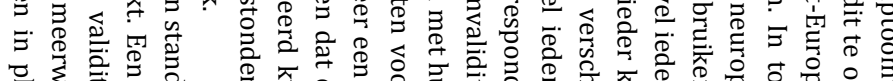

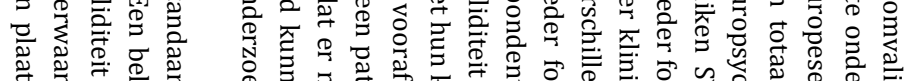

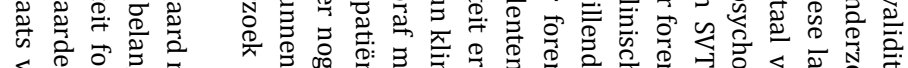

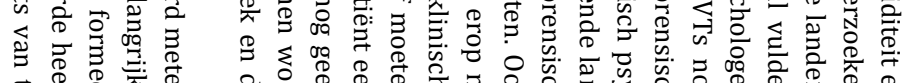

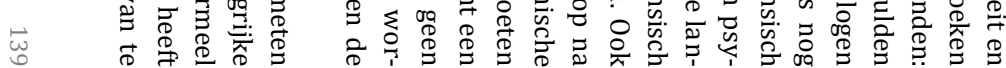

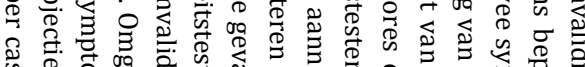

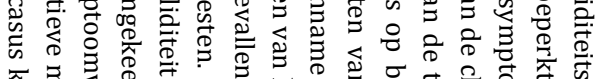

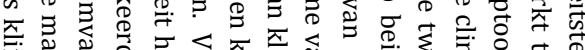

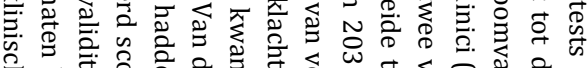

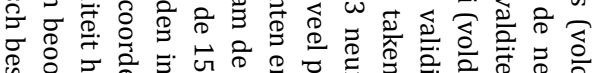

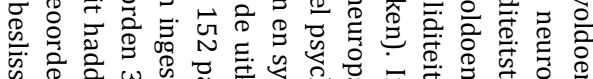

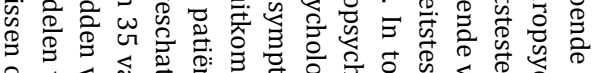

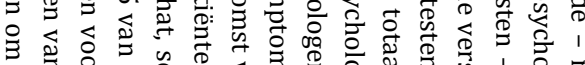

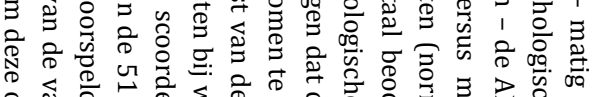

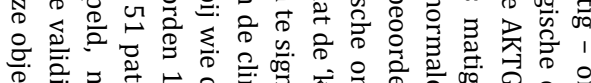

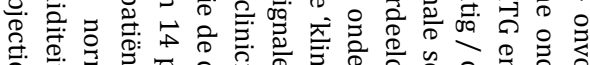

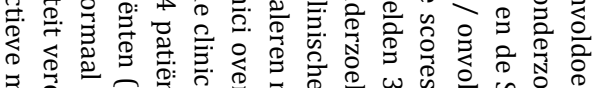

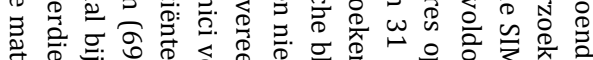

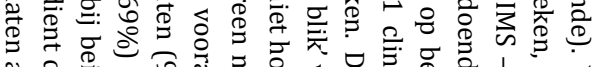

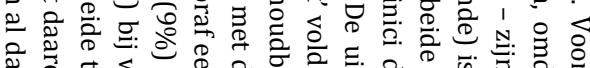

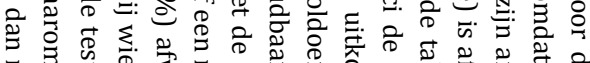

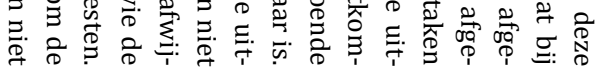




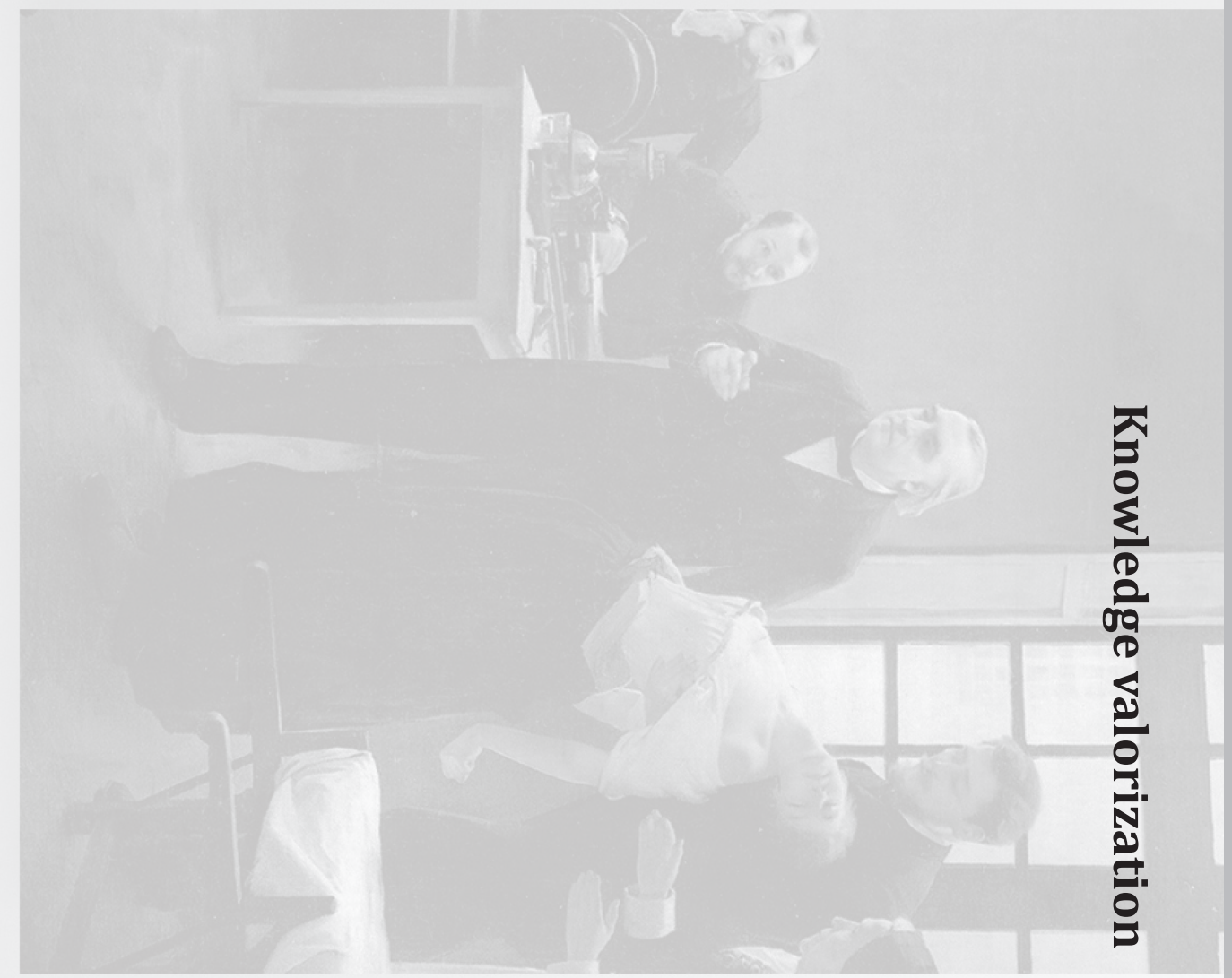




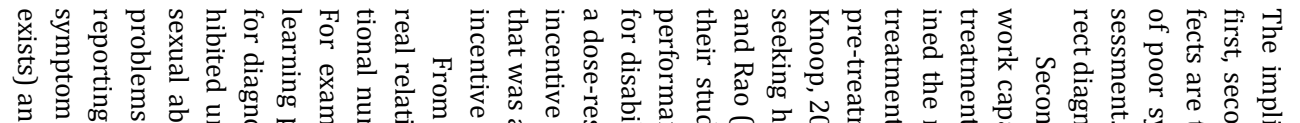

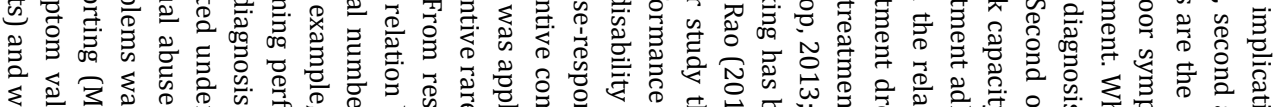

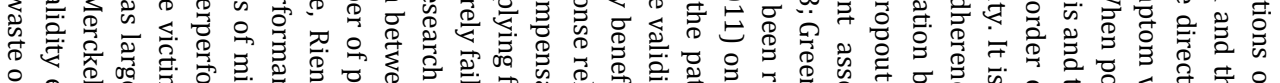

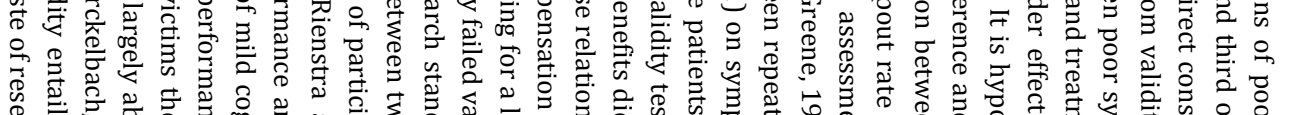

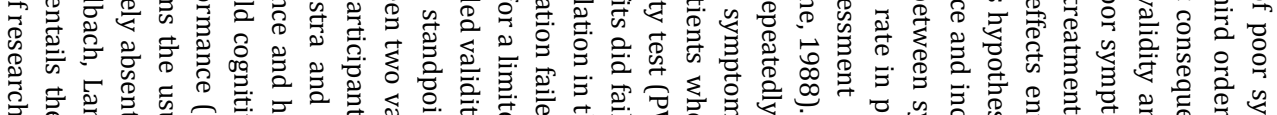

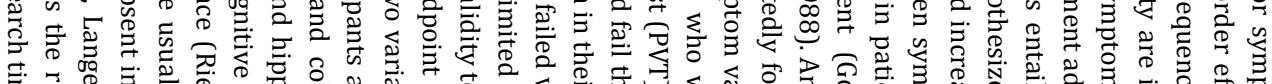

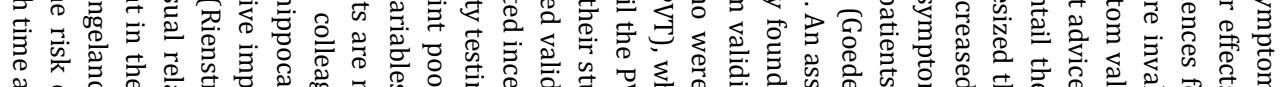

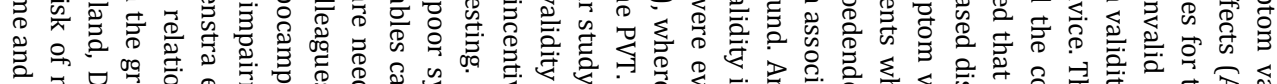

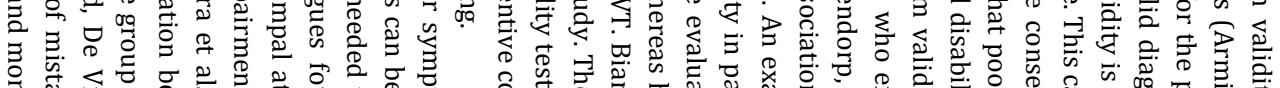

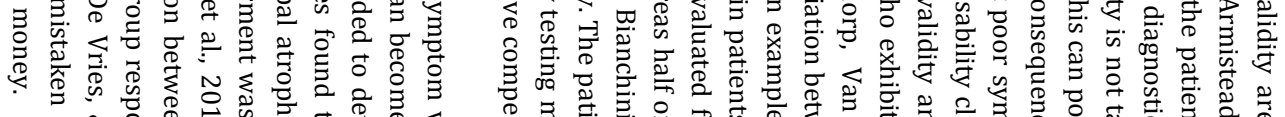

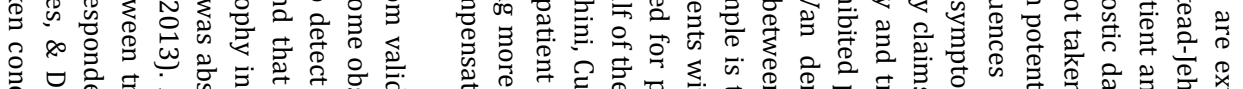

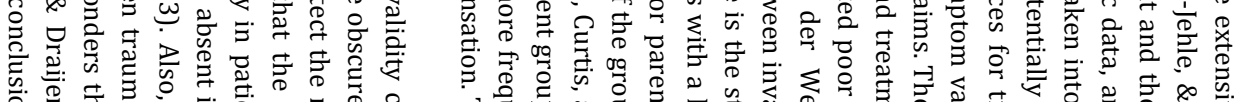

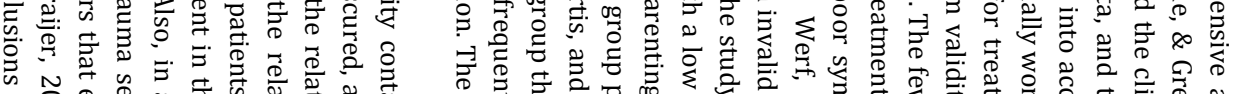

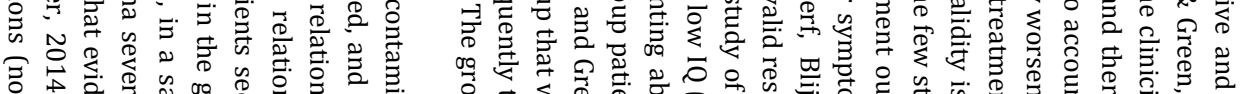

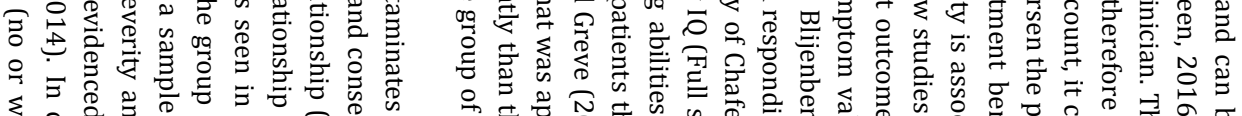

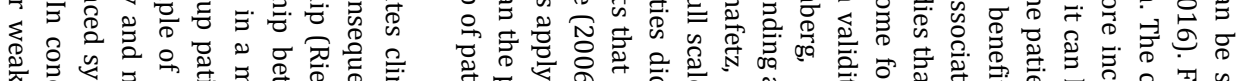

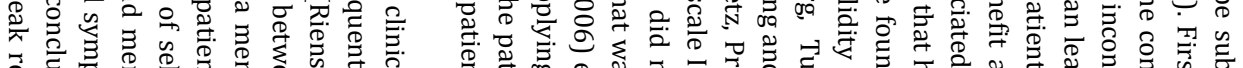

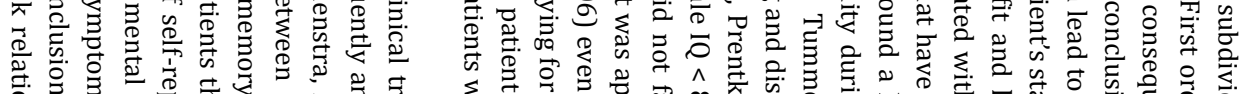

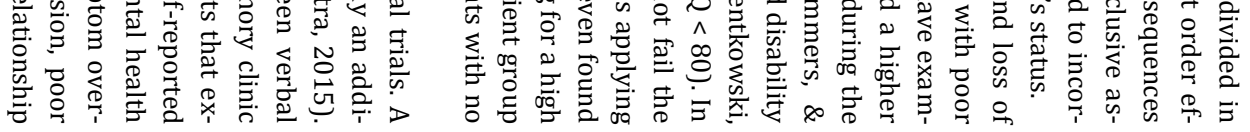

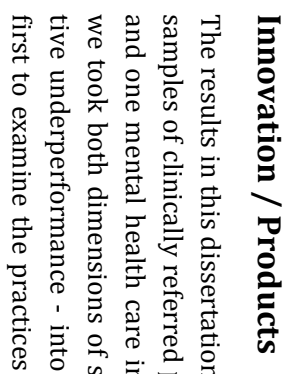

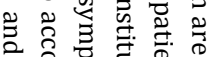
○ 票 के 至.

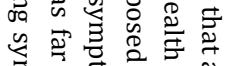
类 क

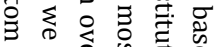

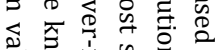

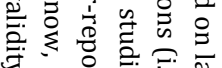

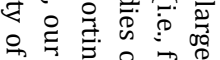
至

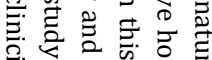

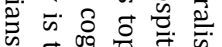

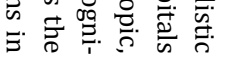

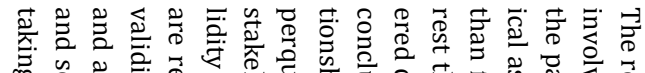

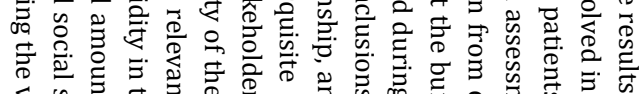

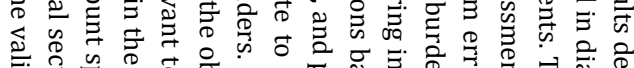

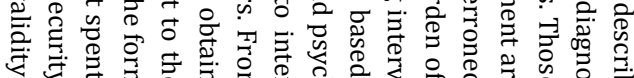

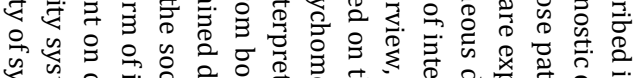

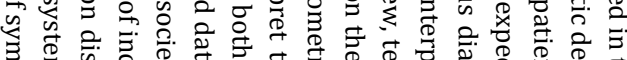

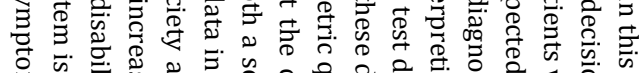

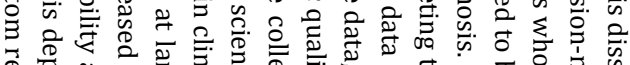

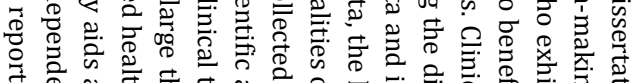

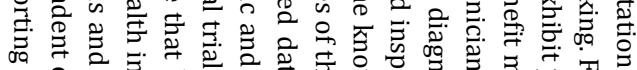

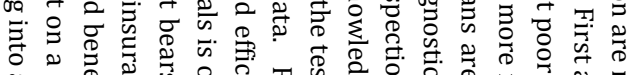

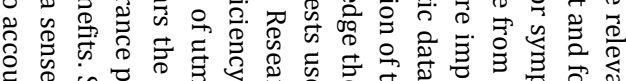

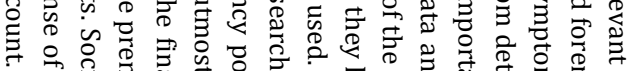

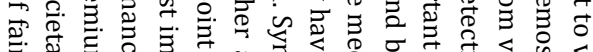

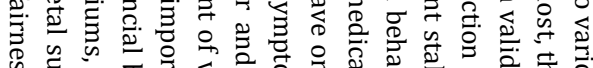

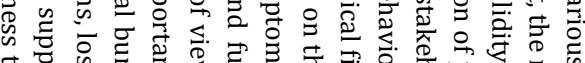

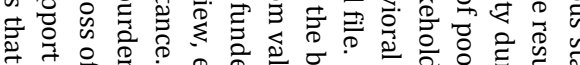

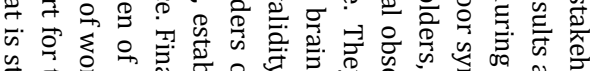

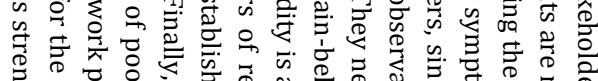

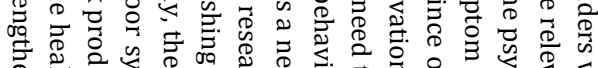

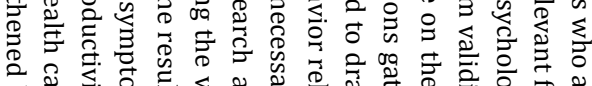

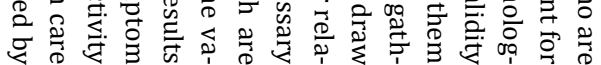

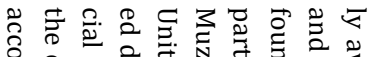

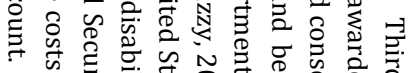

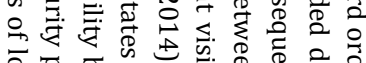

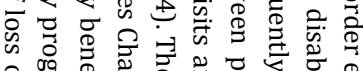

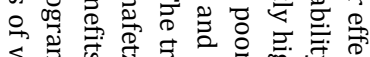

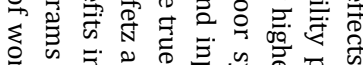

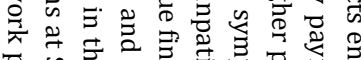

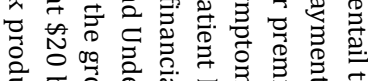

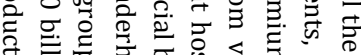

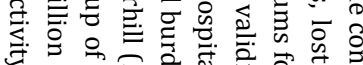
च

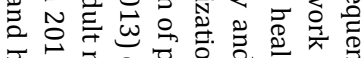
б.

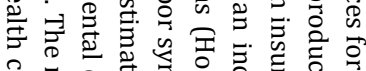

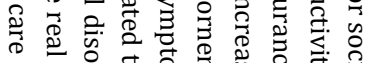
ट.

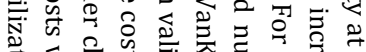

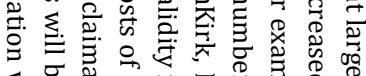

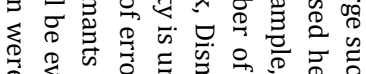

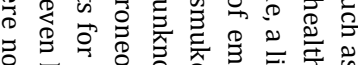

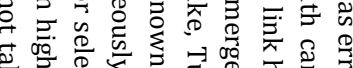

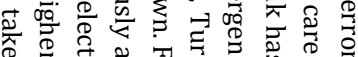

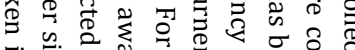

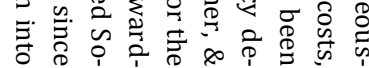




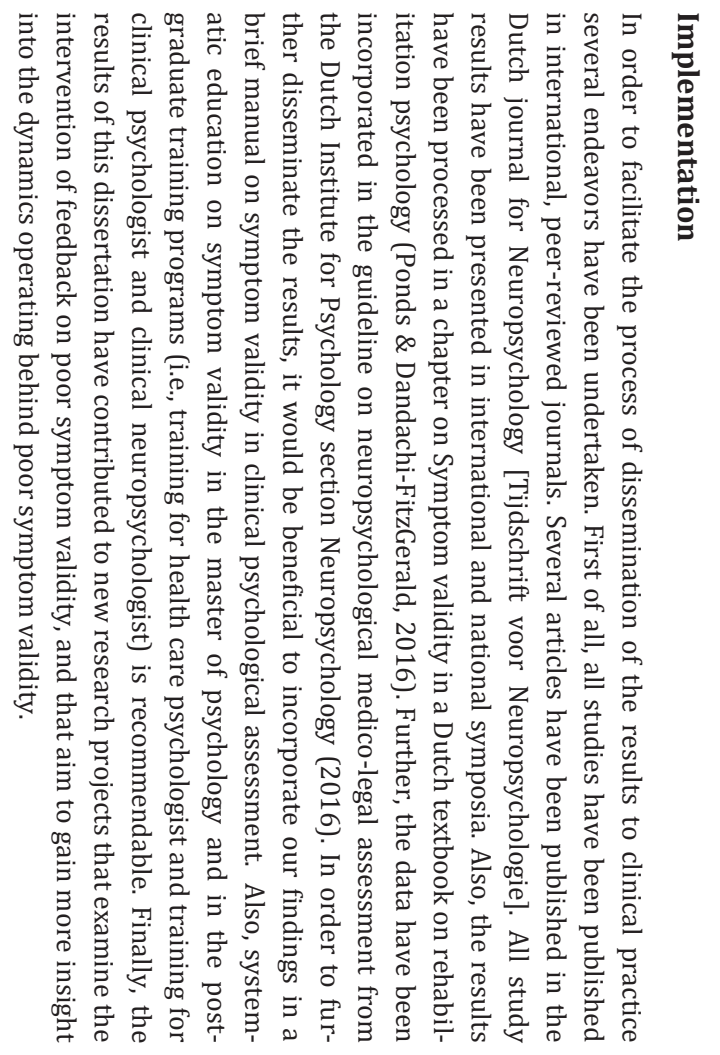

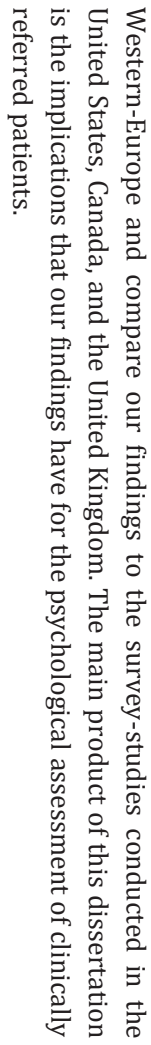

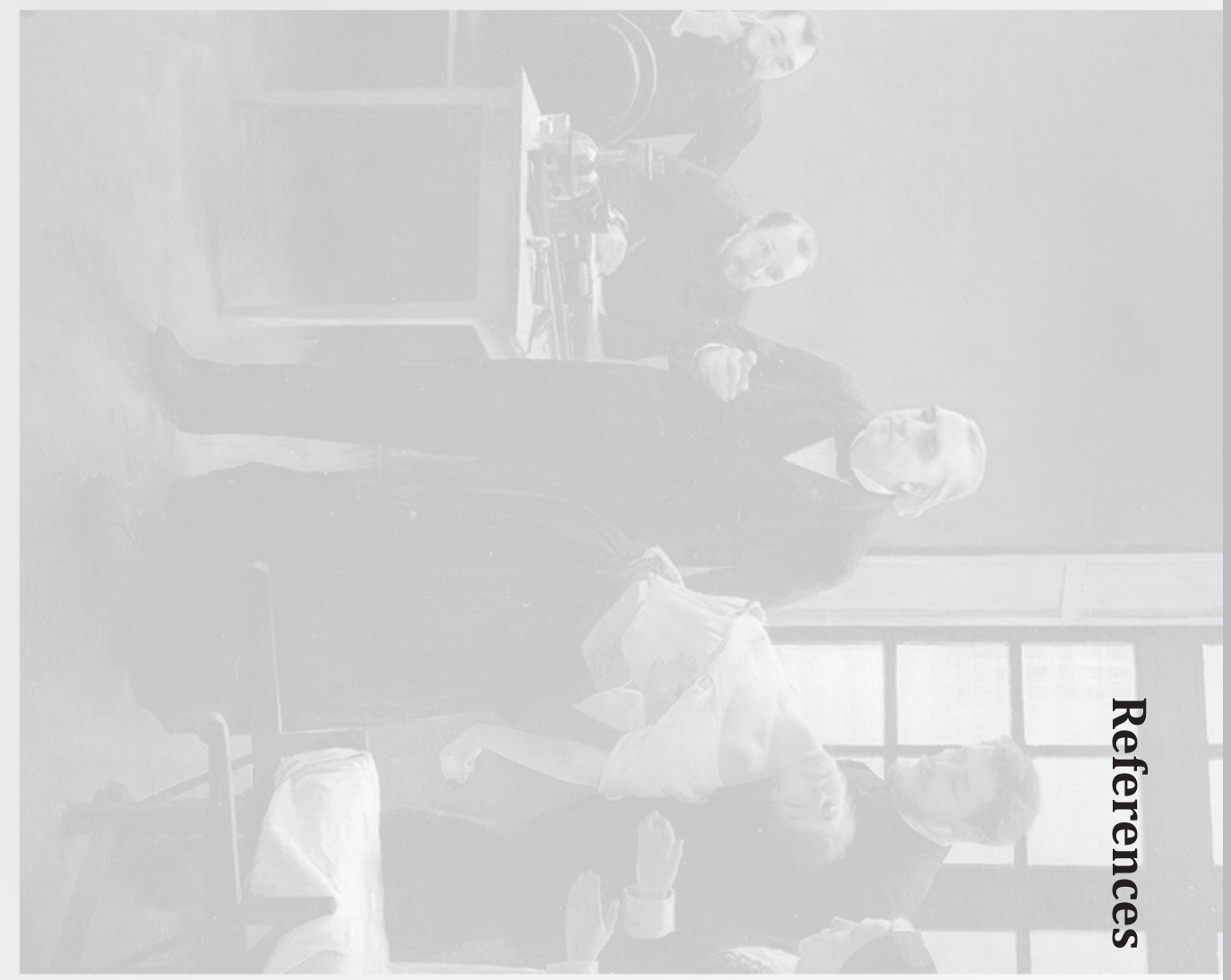




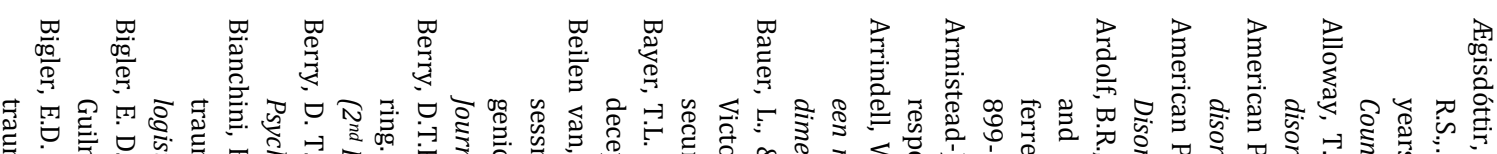

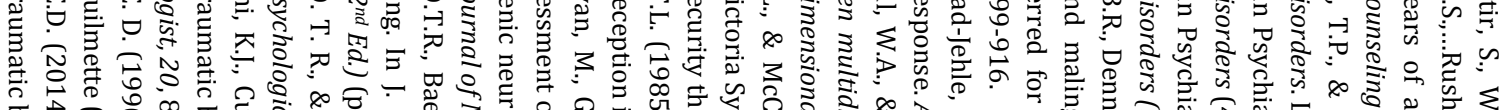

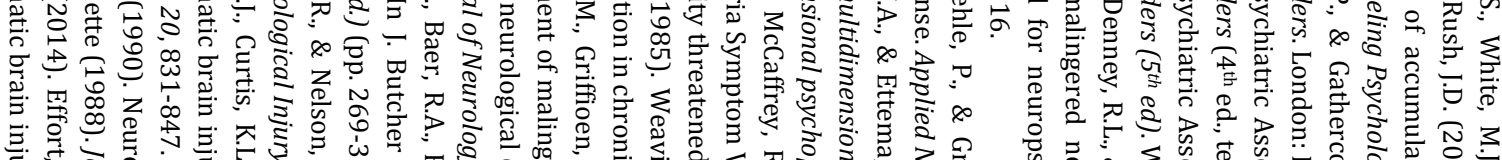

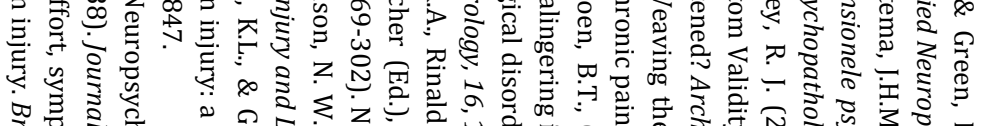

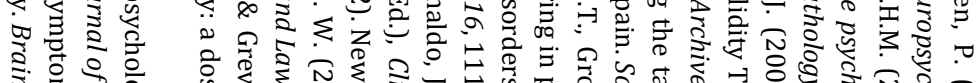

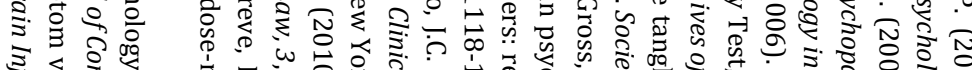

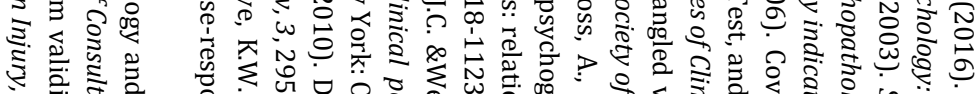

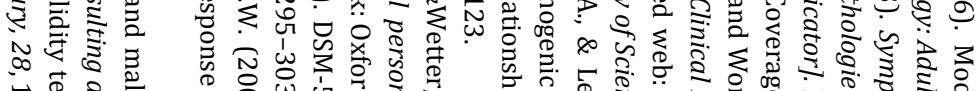

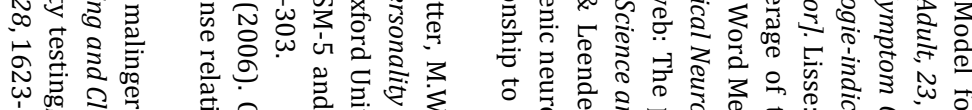

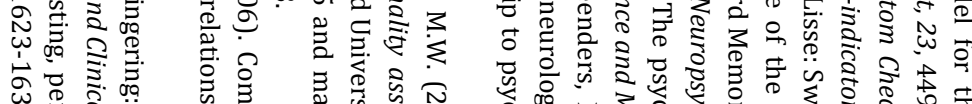

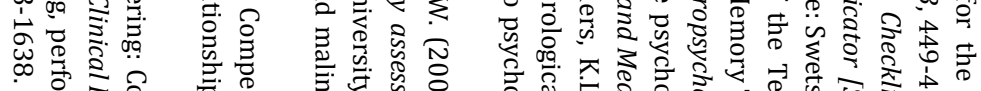

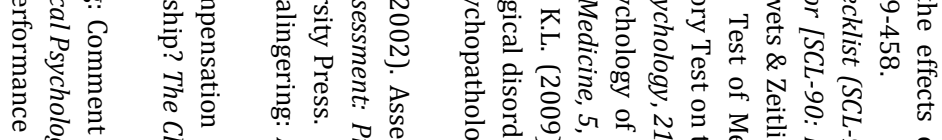

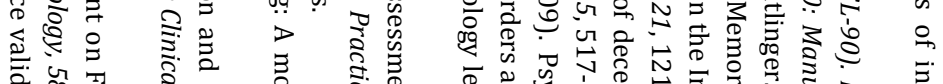

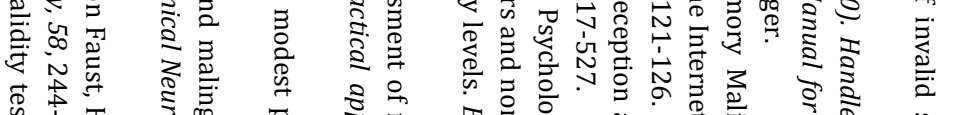

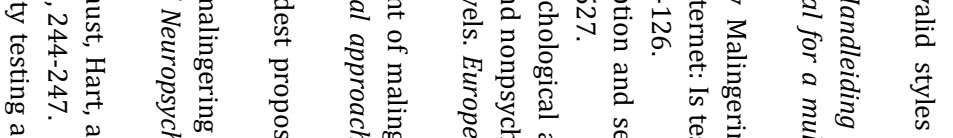

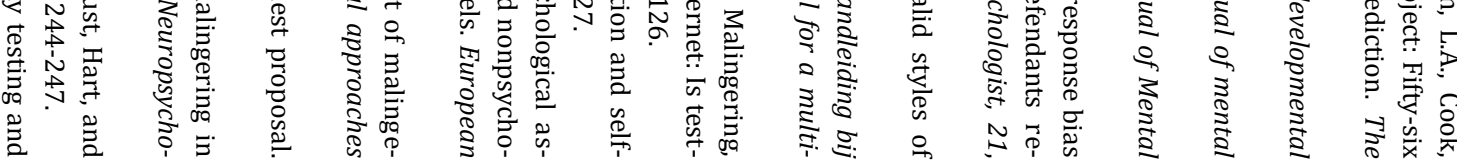

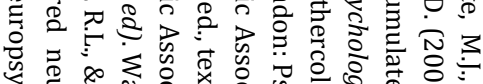

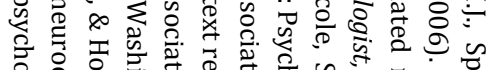

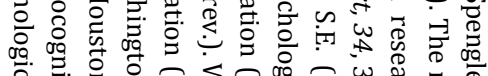

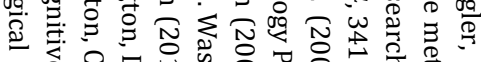

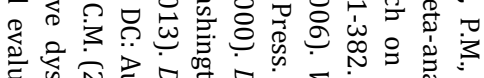

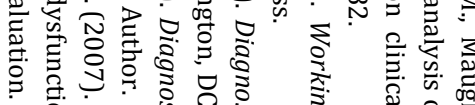

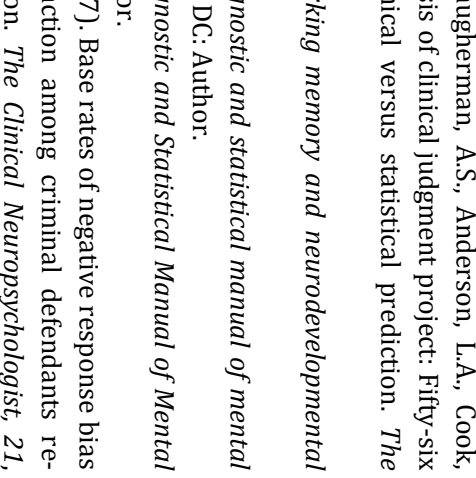

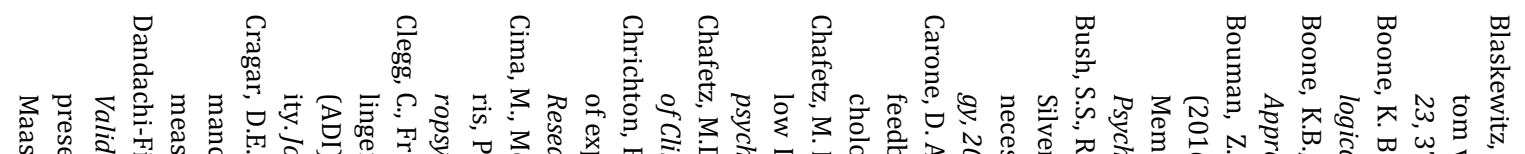

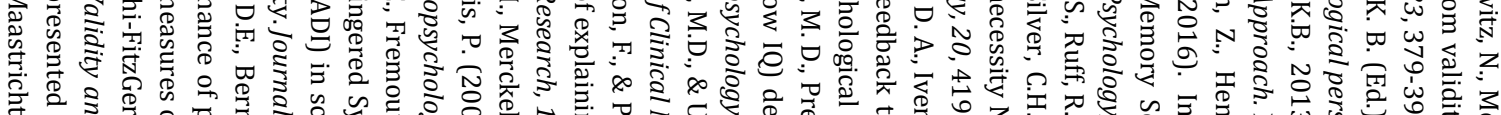

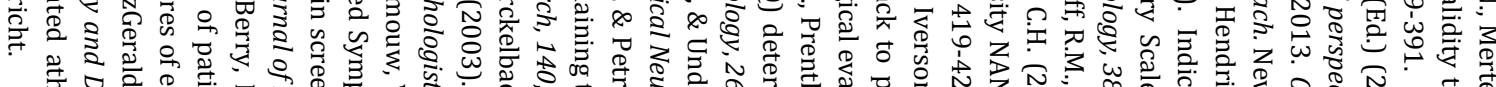

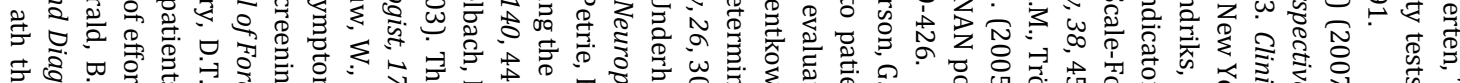

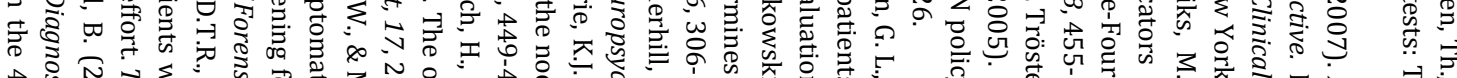

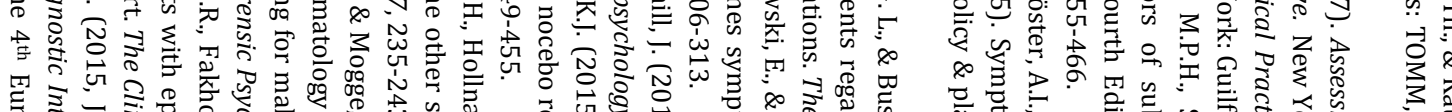

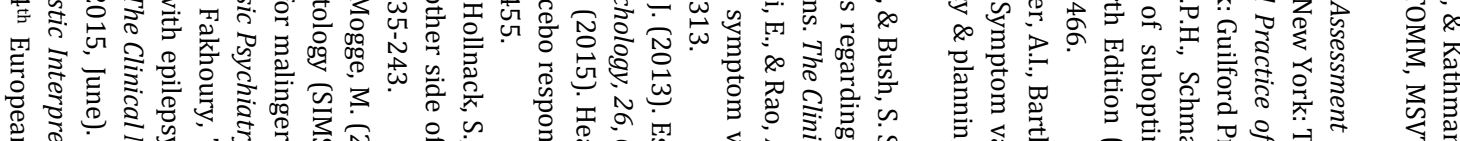

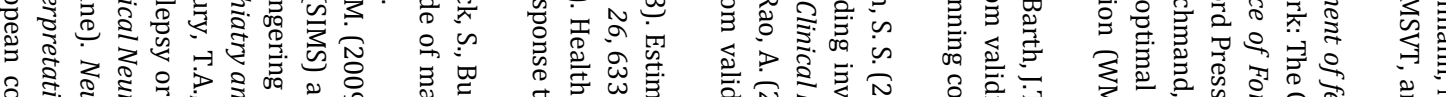

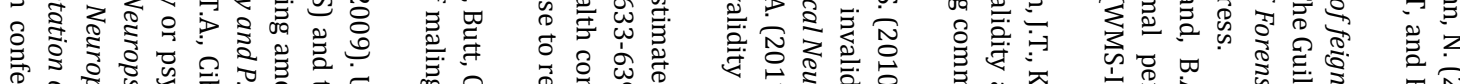

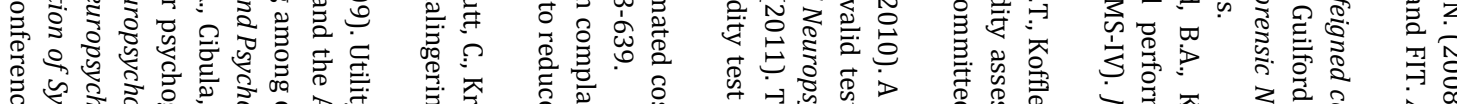
万人

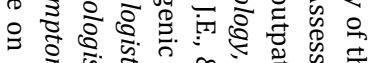

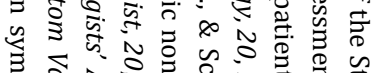

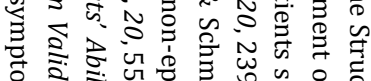

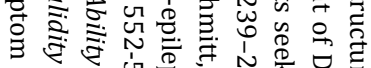

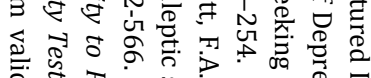

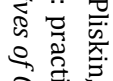

ㄹ. ㄱ.

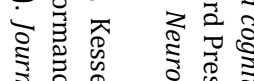

@

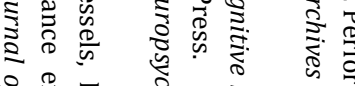

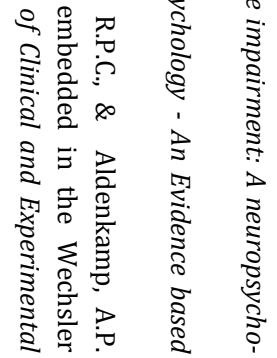

일 


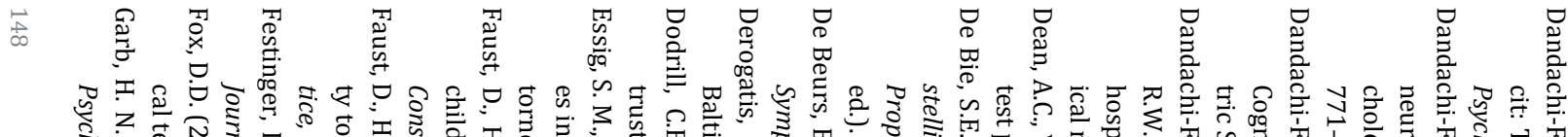

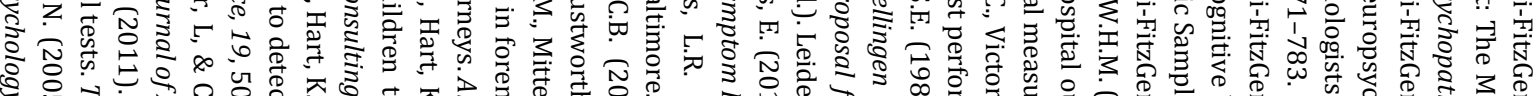

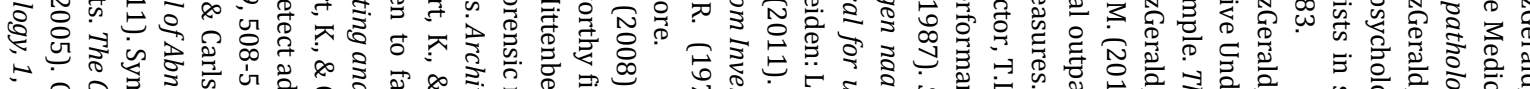

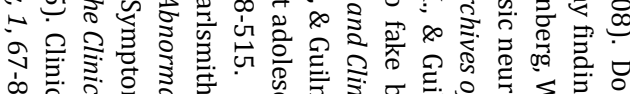

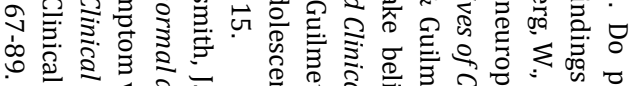

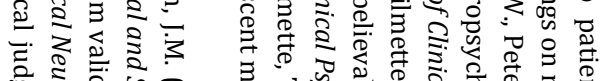

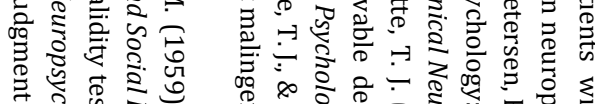

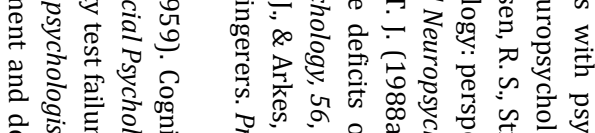

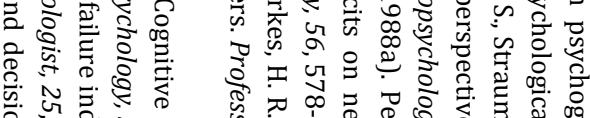

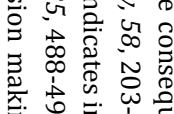

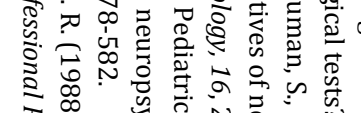

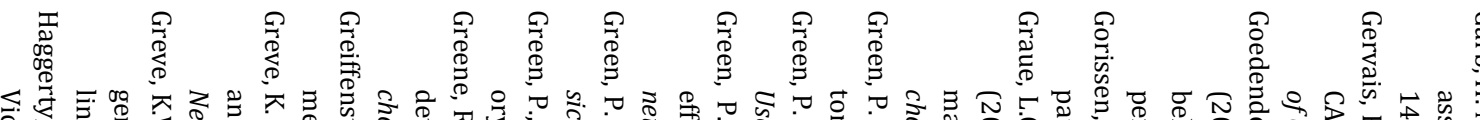

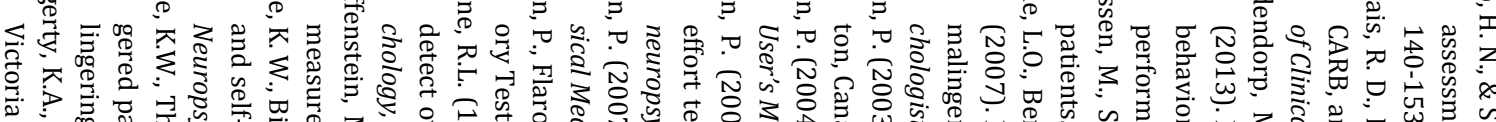

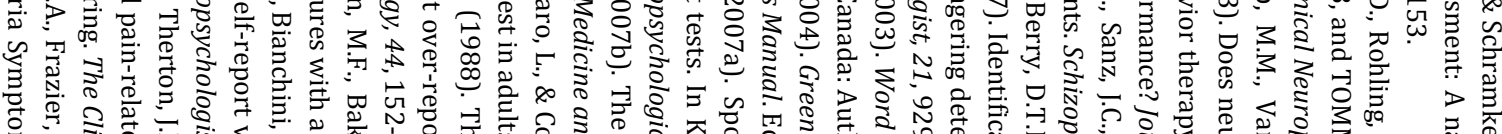

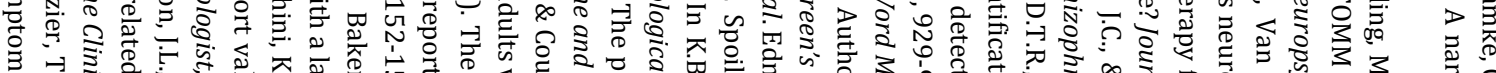

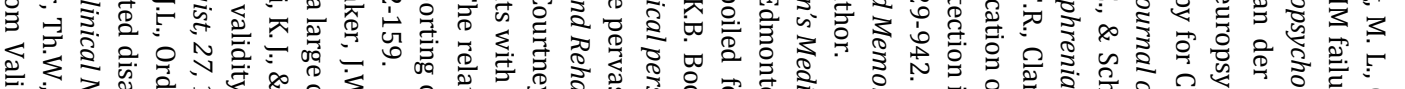

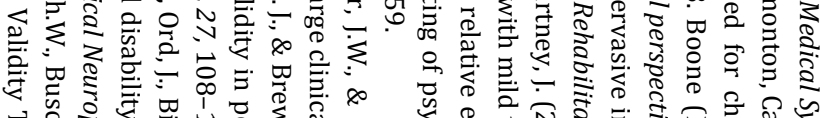

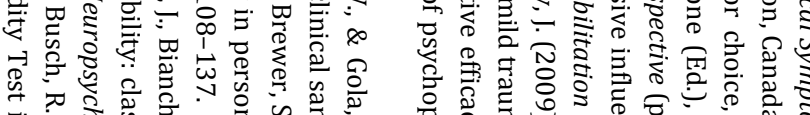

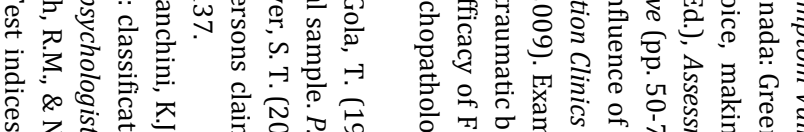

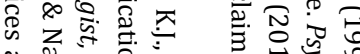

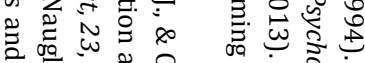

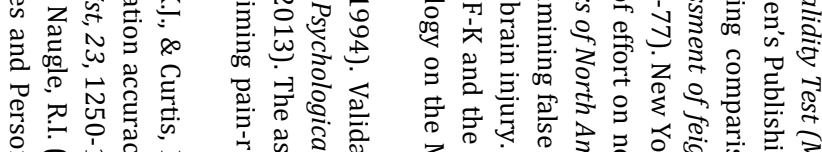

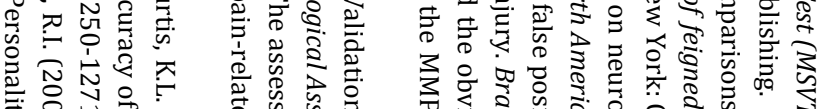

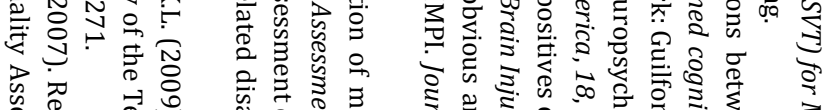

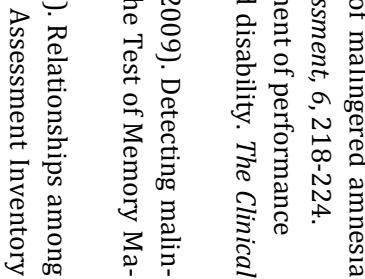

坟

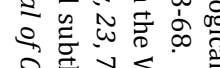

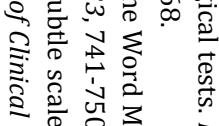

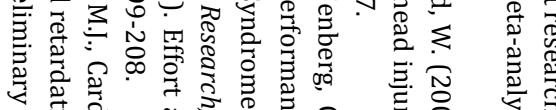

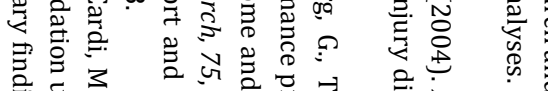

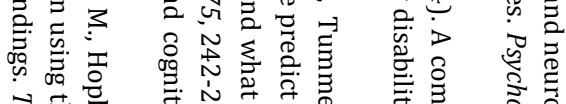

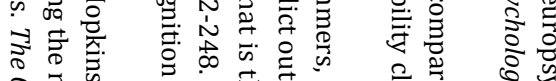

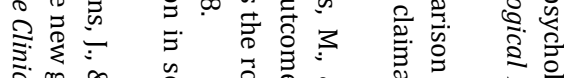

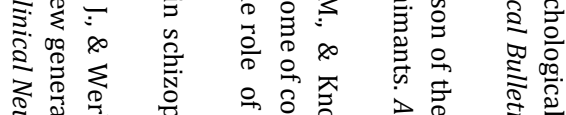

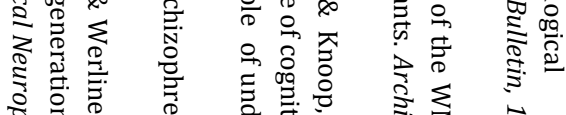

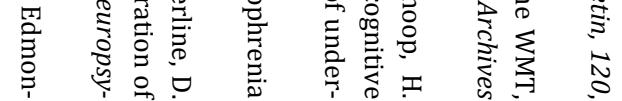




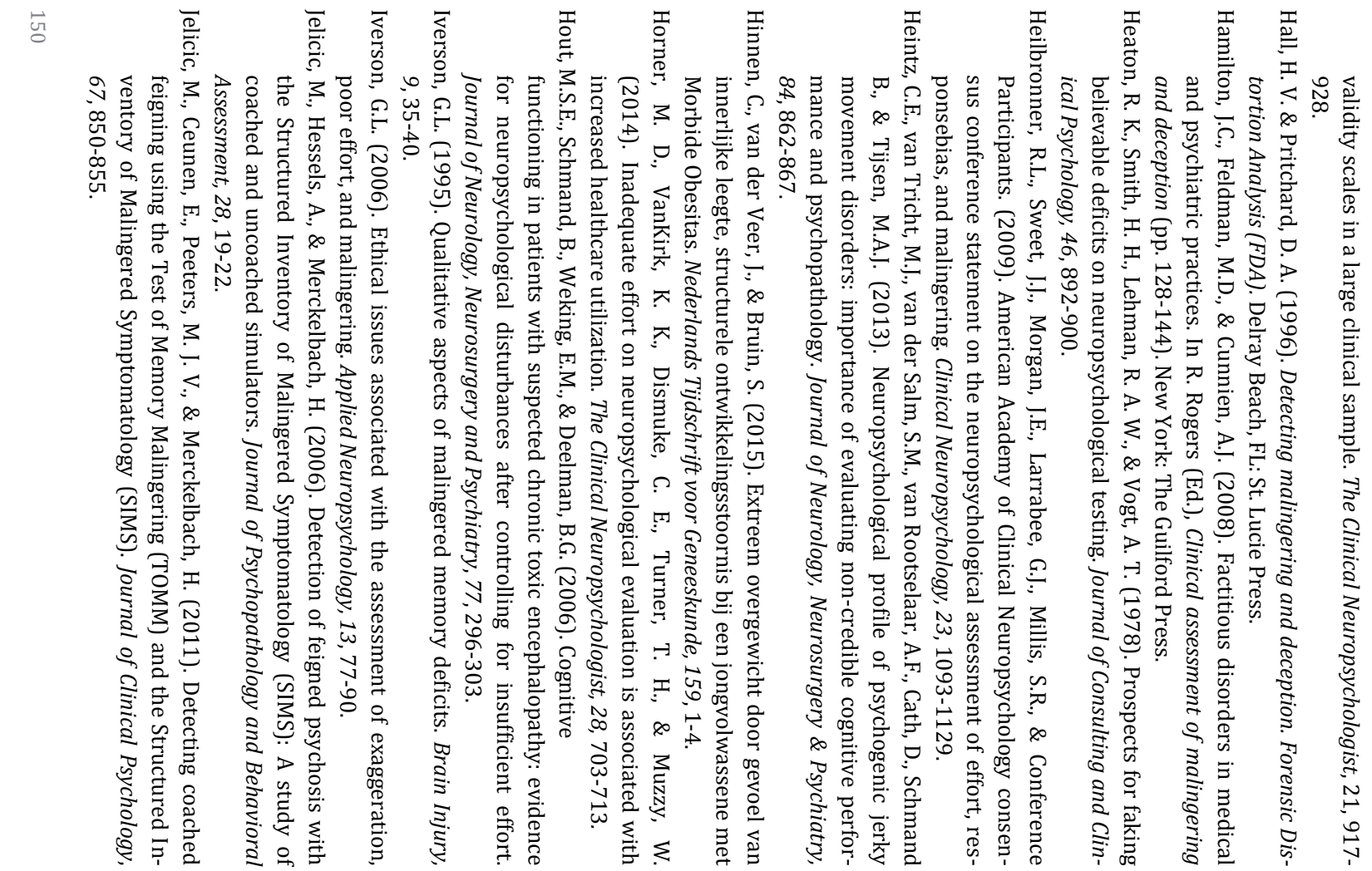

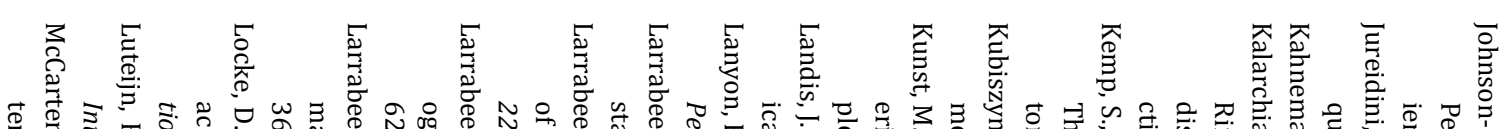

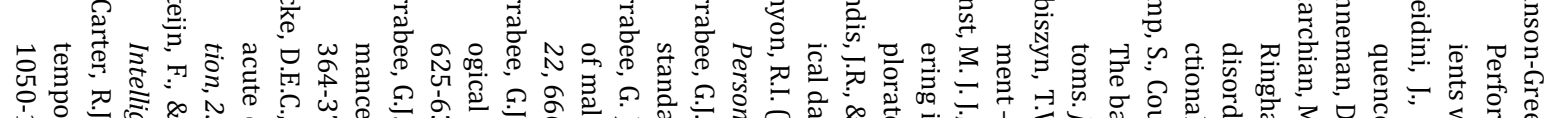

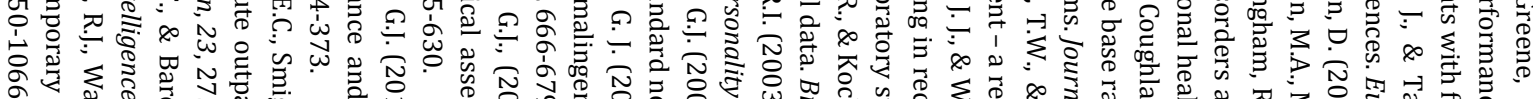

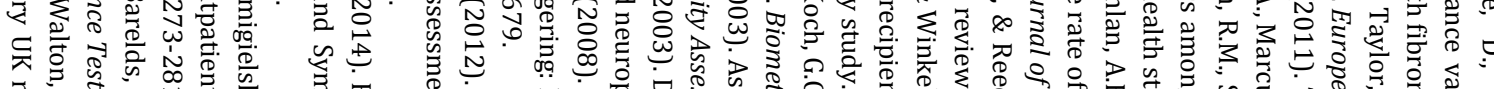

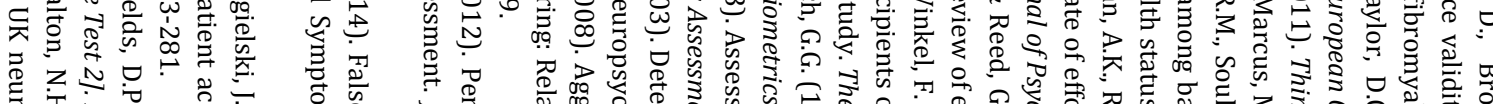

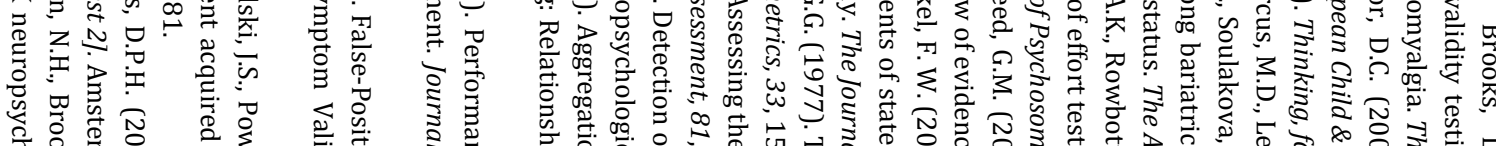

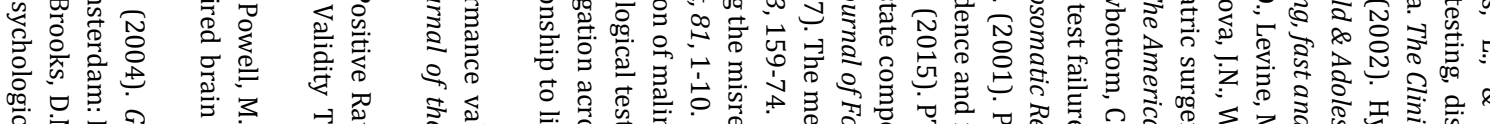

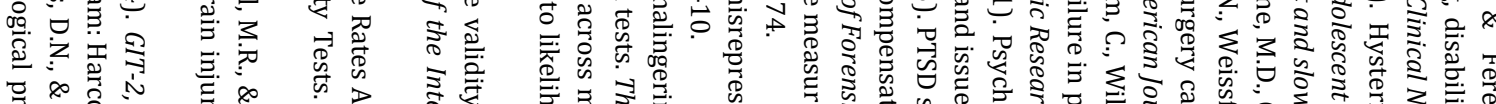

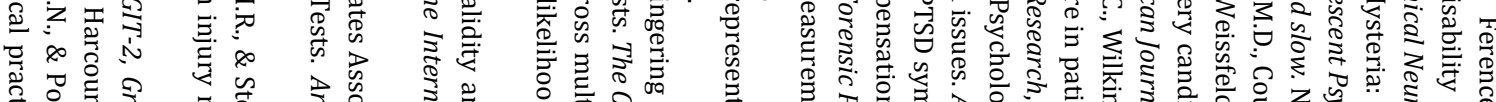

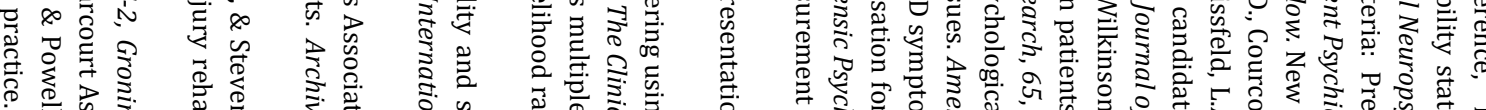

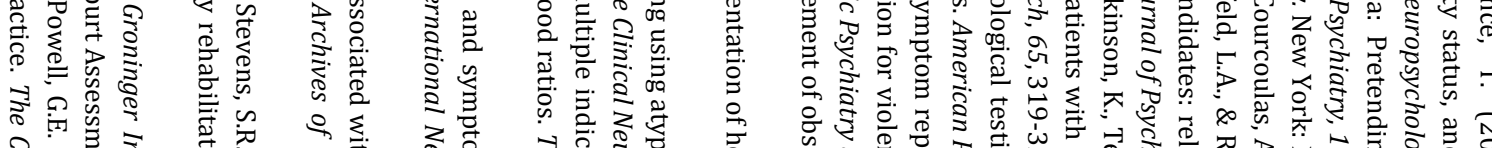

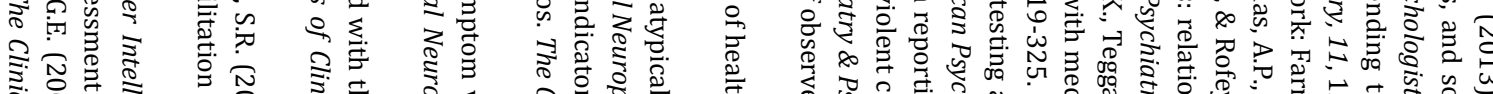

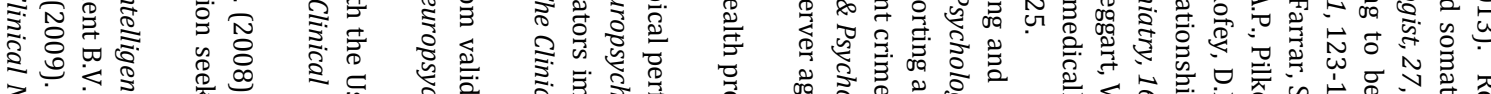

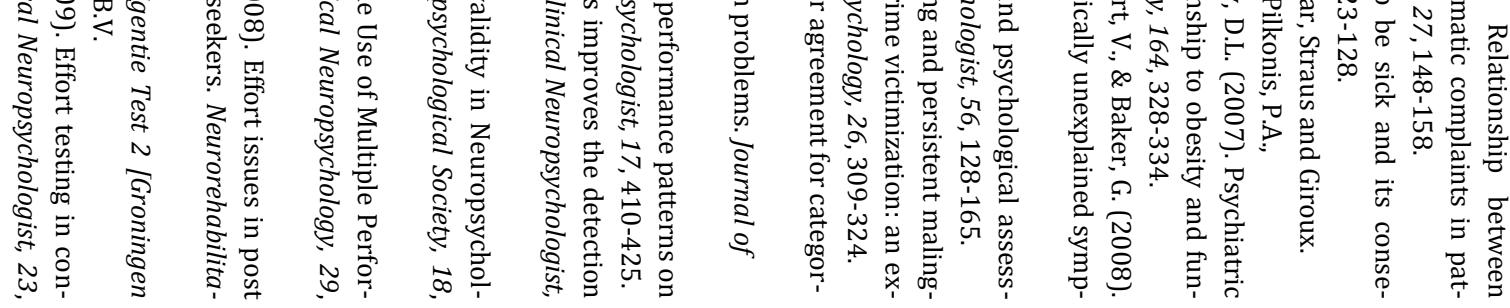




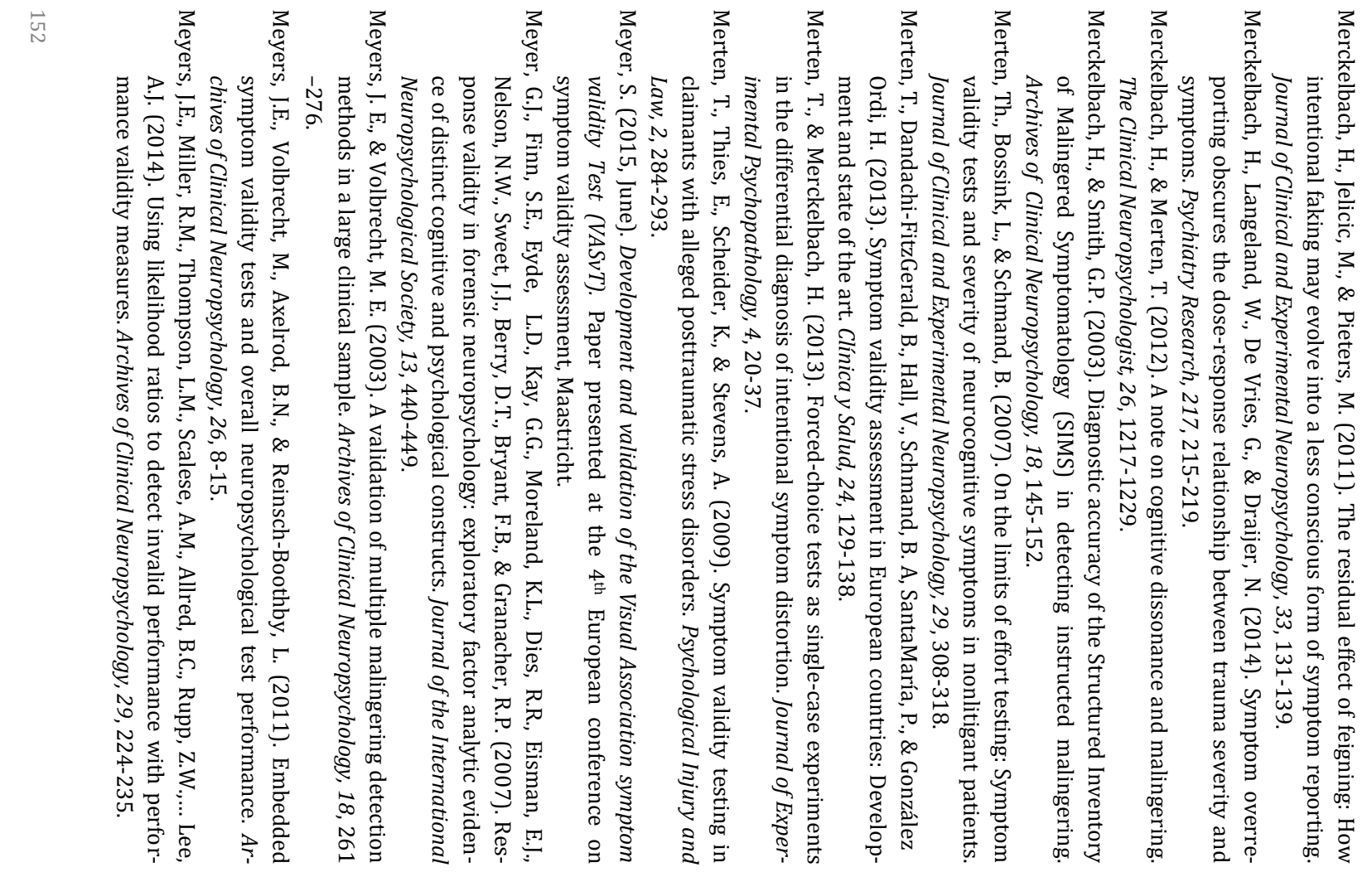




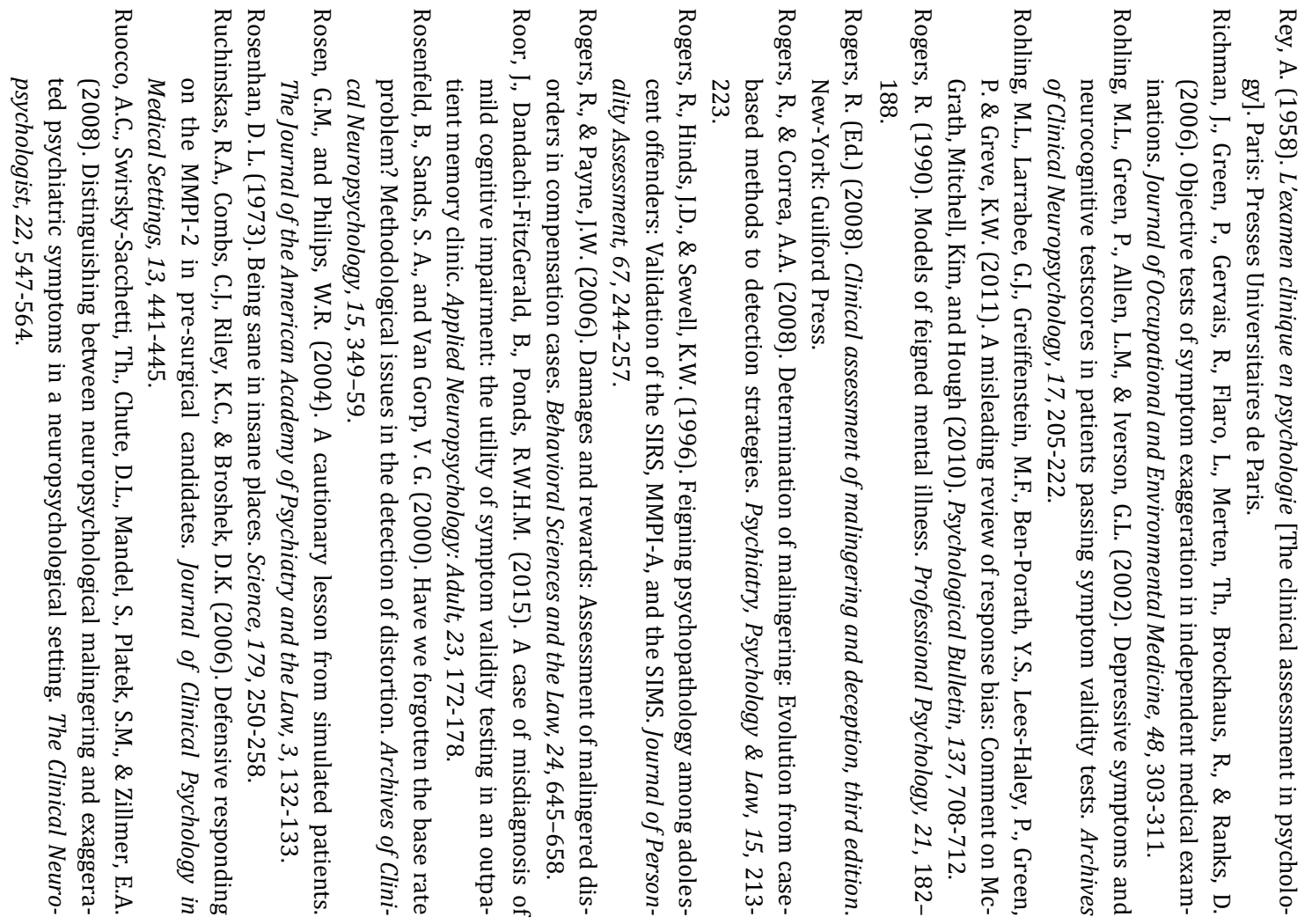

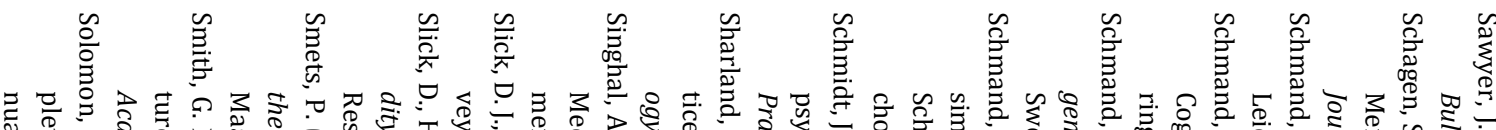

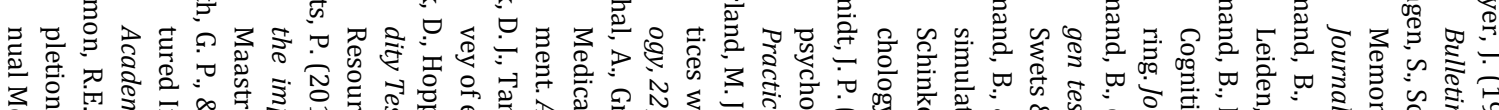

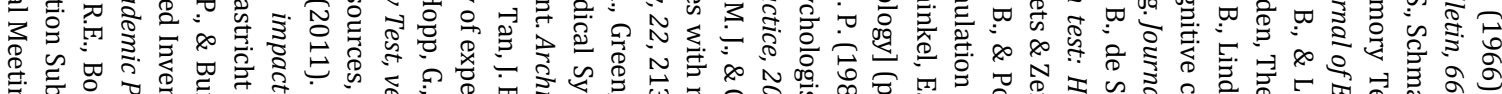

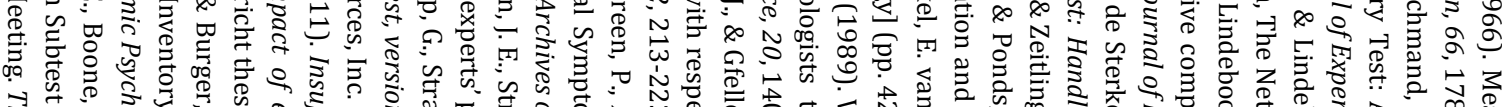

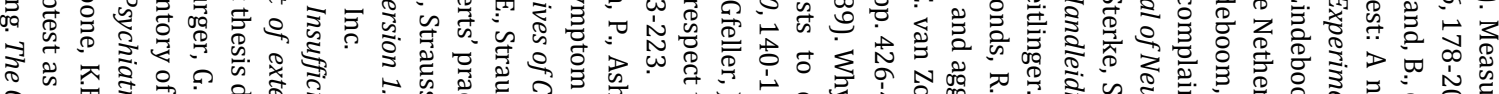

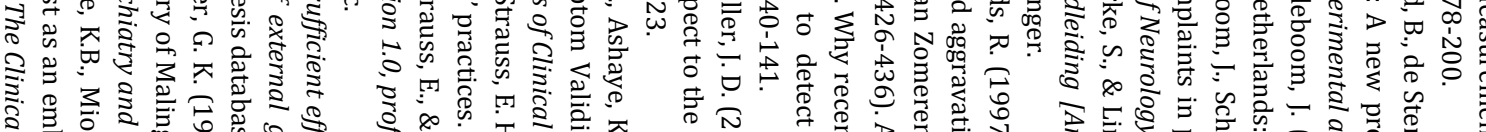

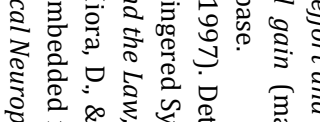

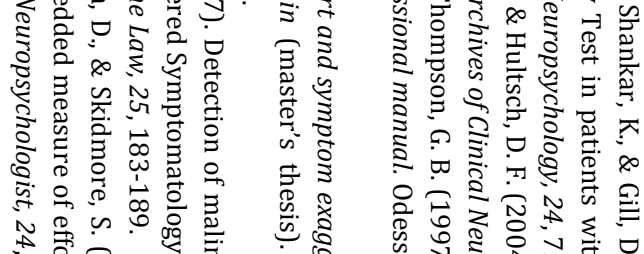

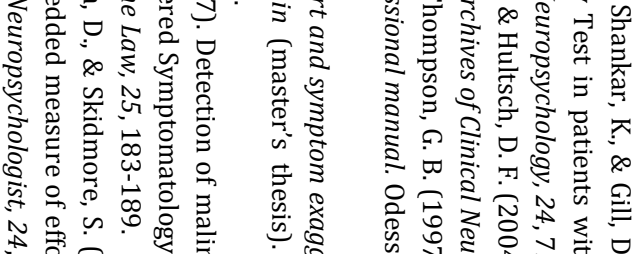

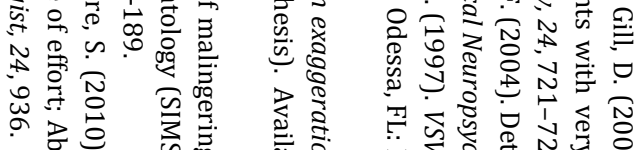

淢

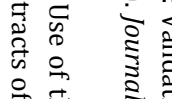

品焉

롤

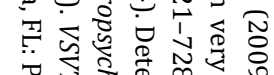

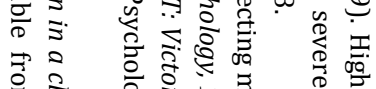

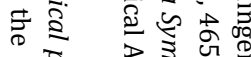
责.

क्ष.

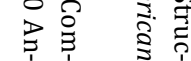

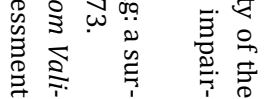

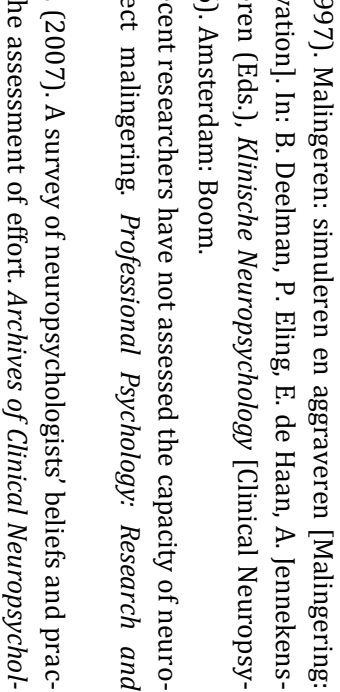

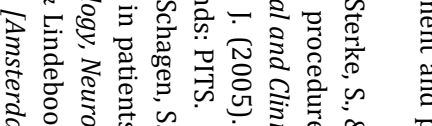

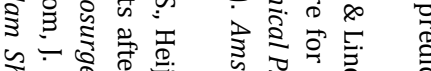

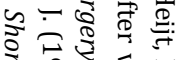
ᄀ उำ

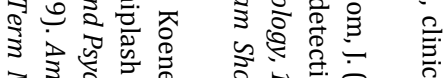

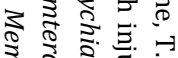

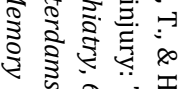
बे बे 穴产

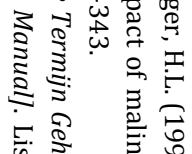

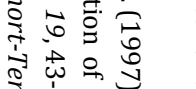

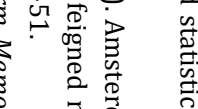




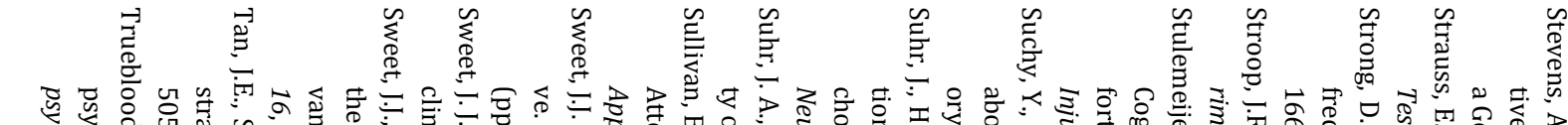

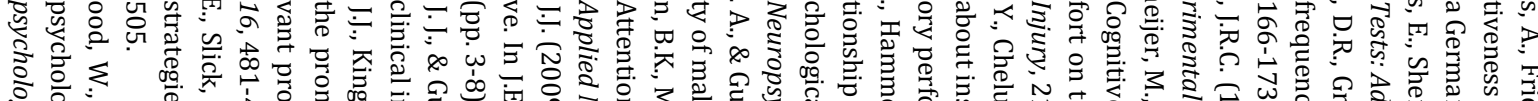

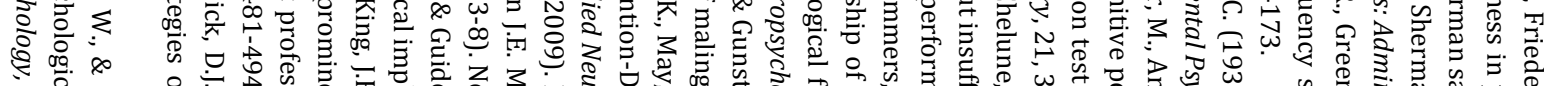

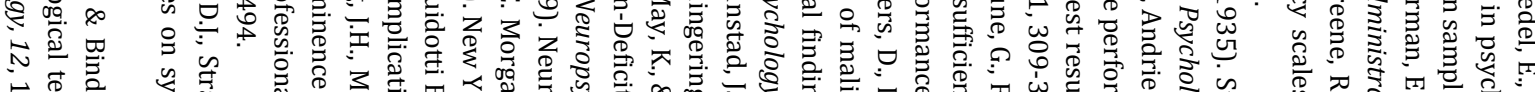

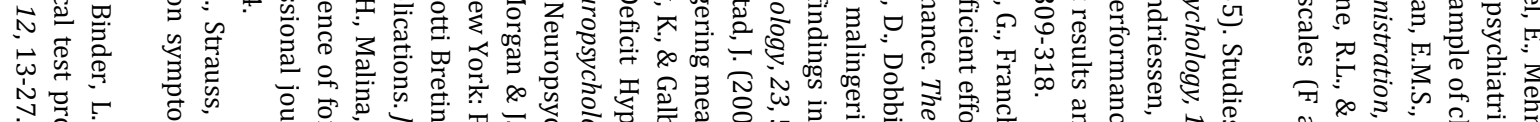

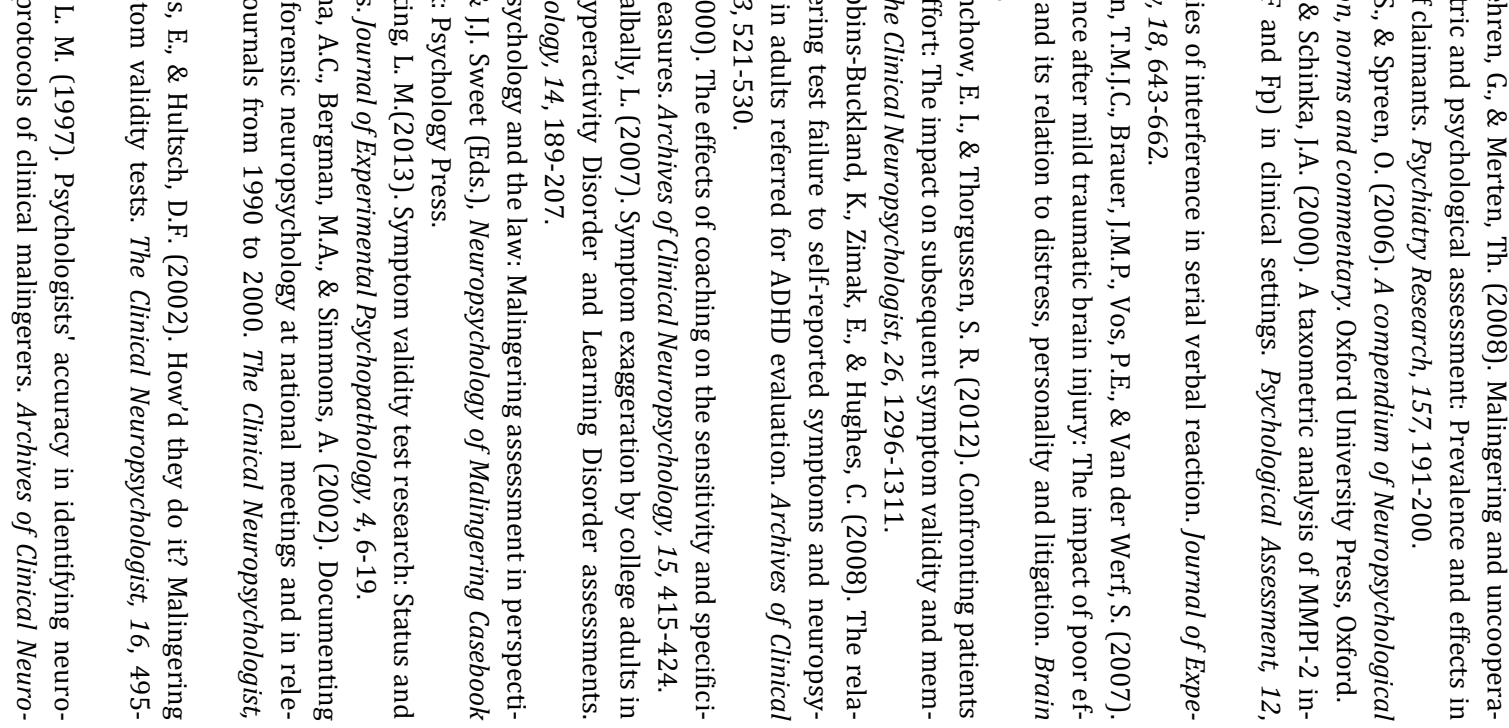

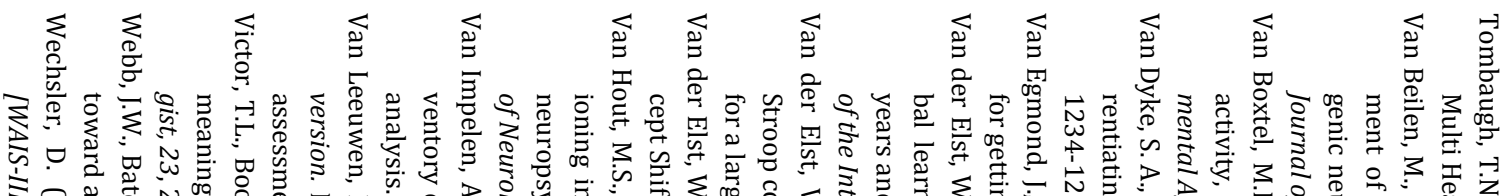

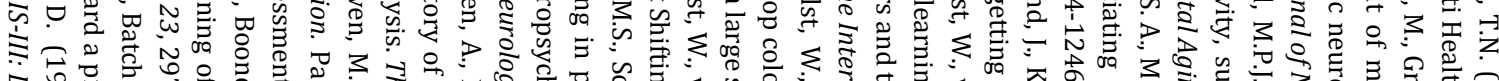

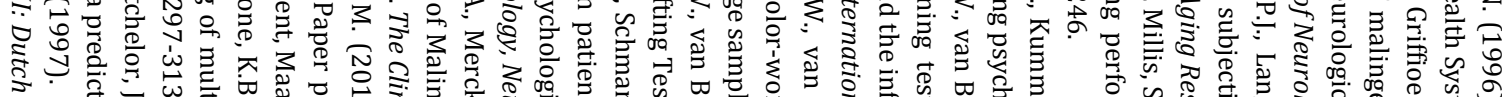

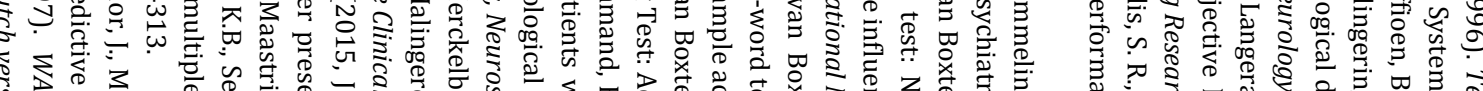

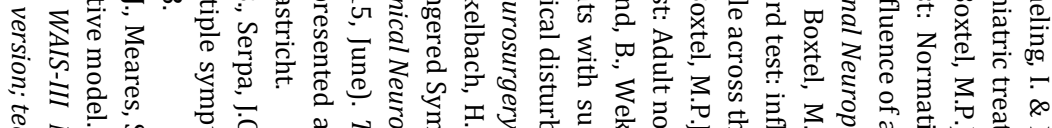

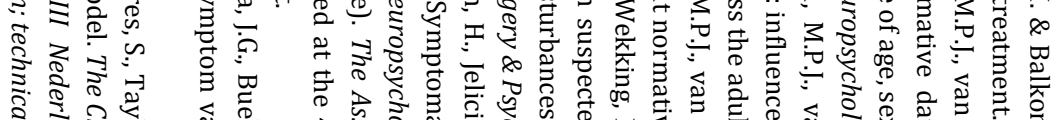

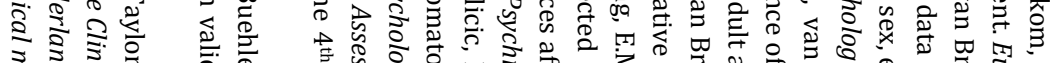

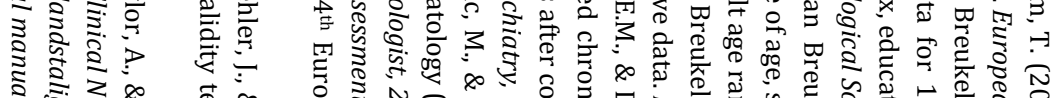
की

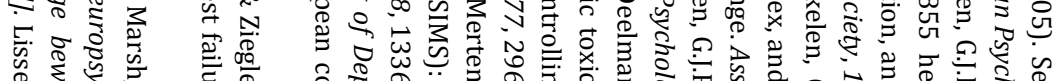

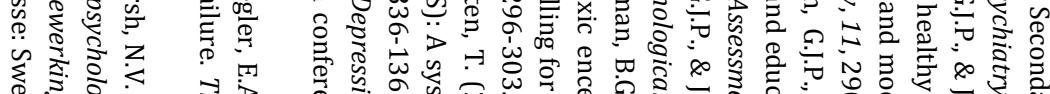

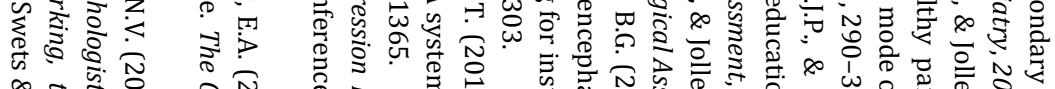

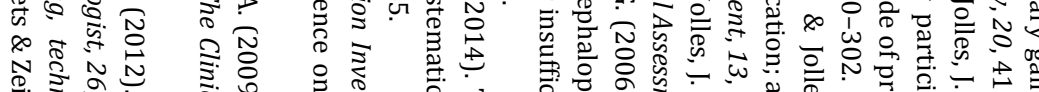

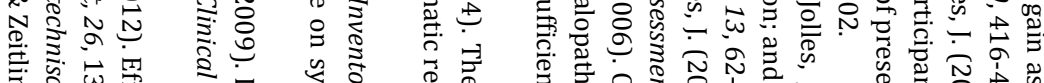

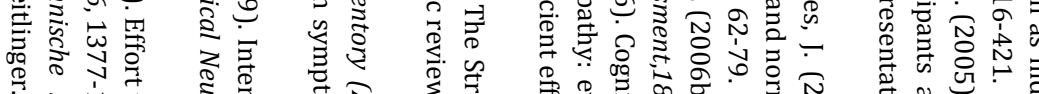

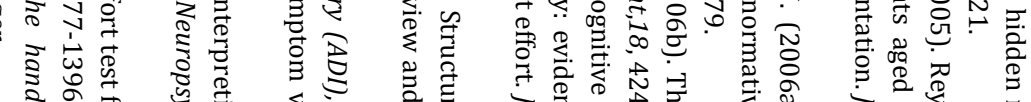

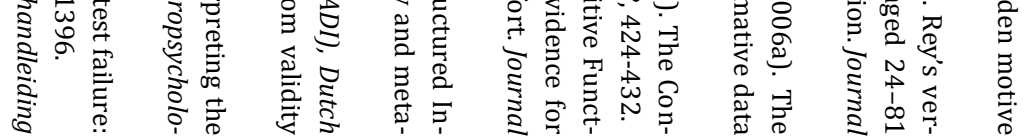

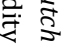
:

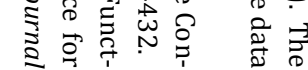




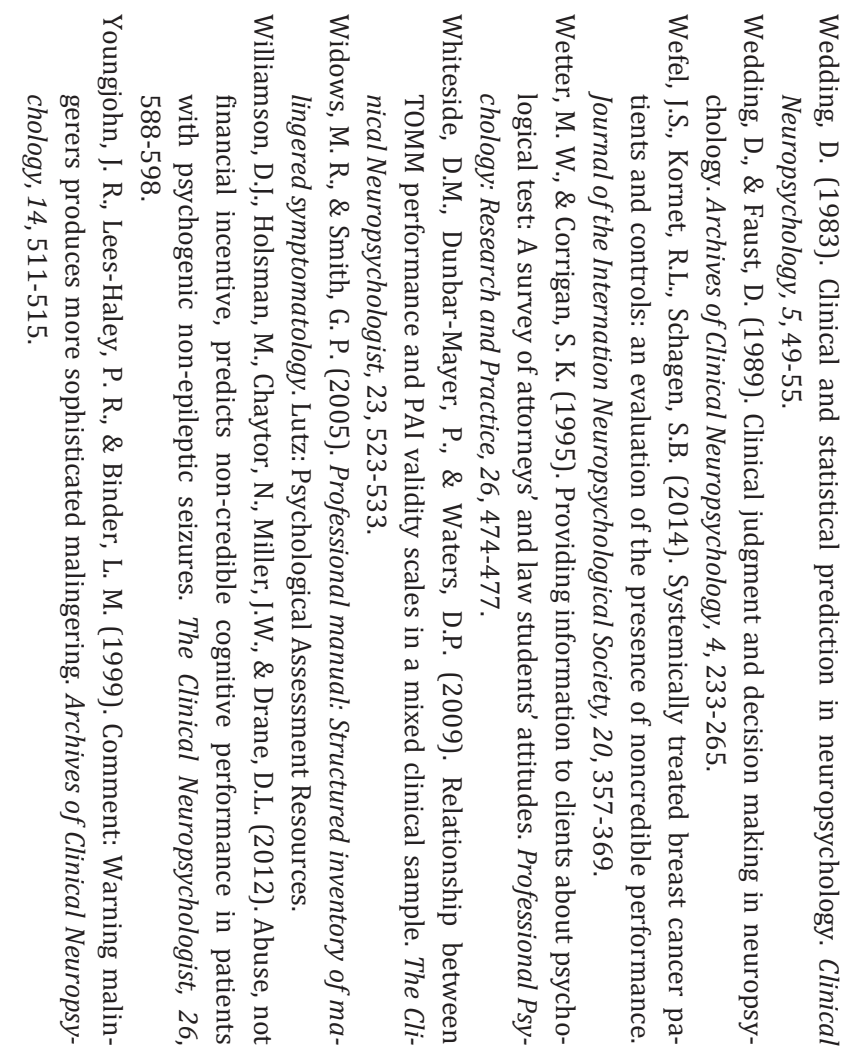




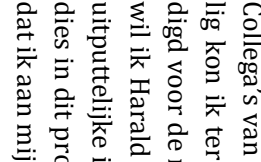

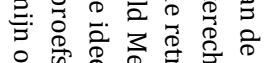

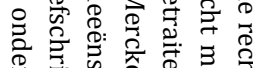

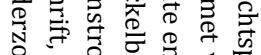
总范

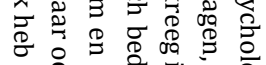

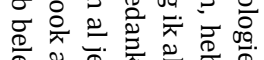

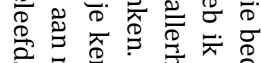

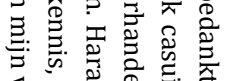

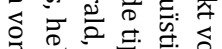

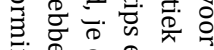

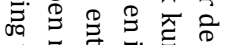

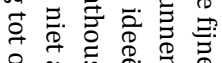

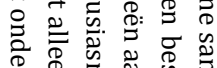

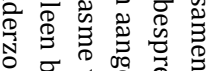

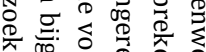

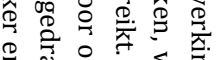

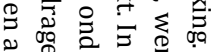

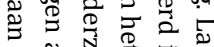

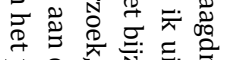

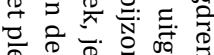
疍.

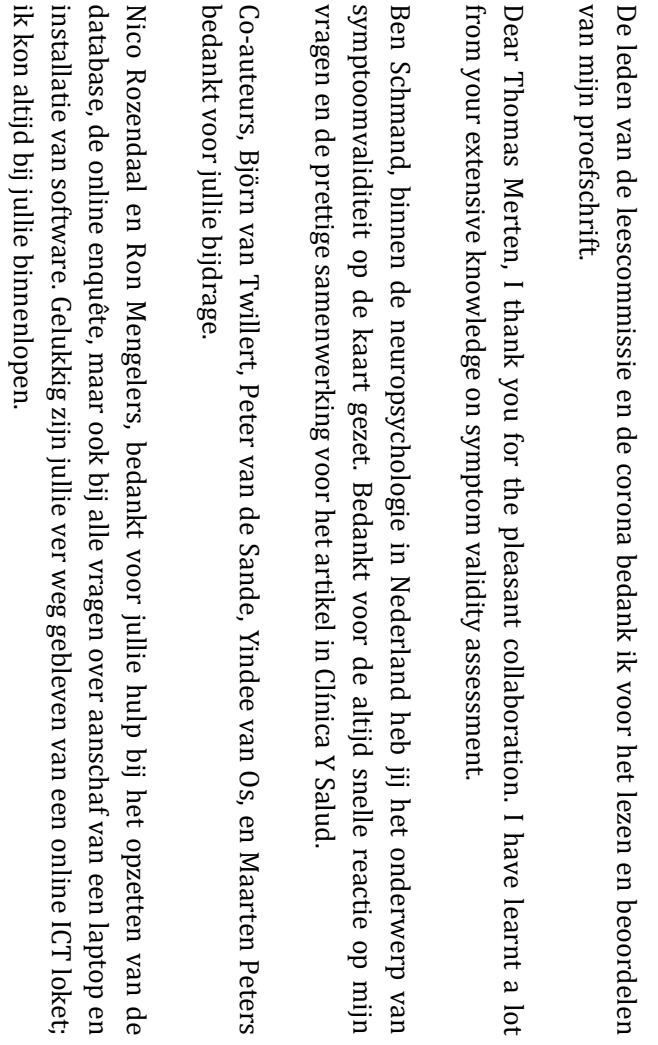

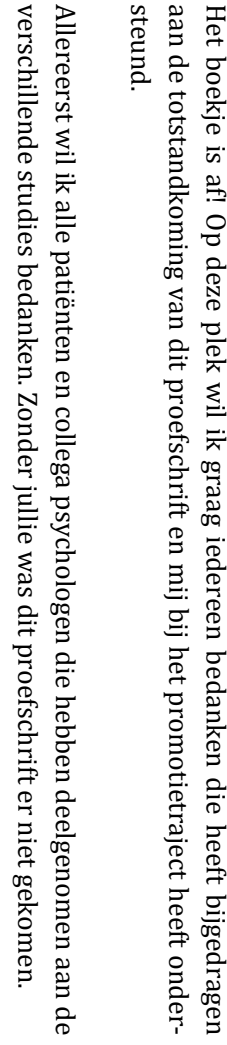

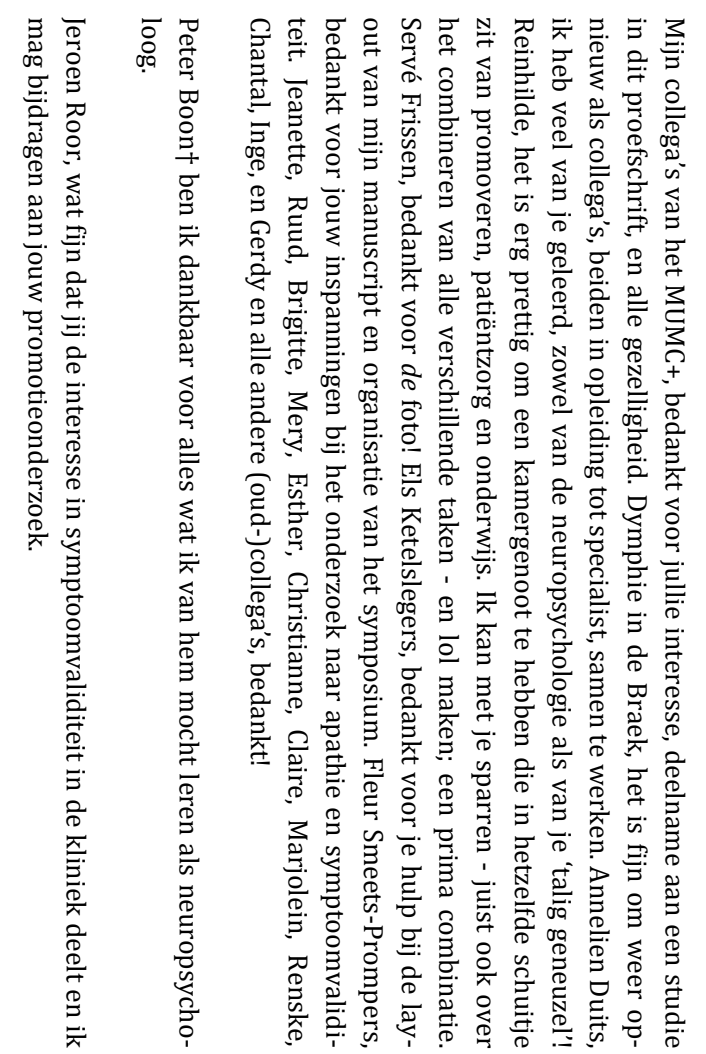

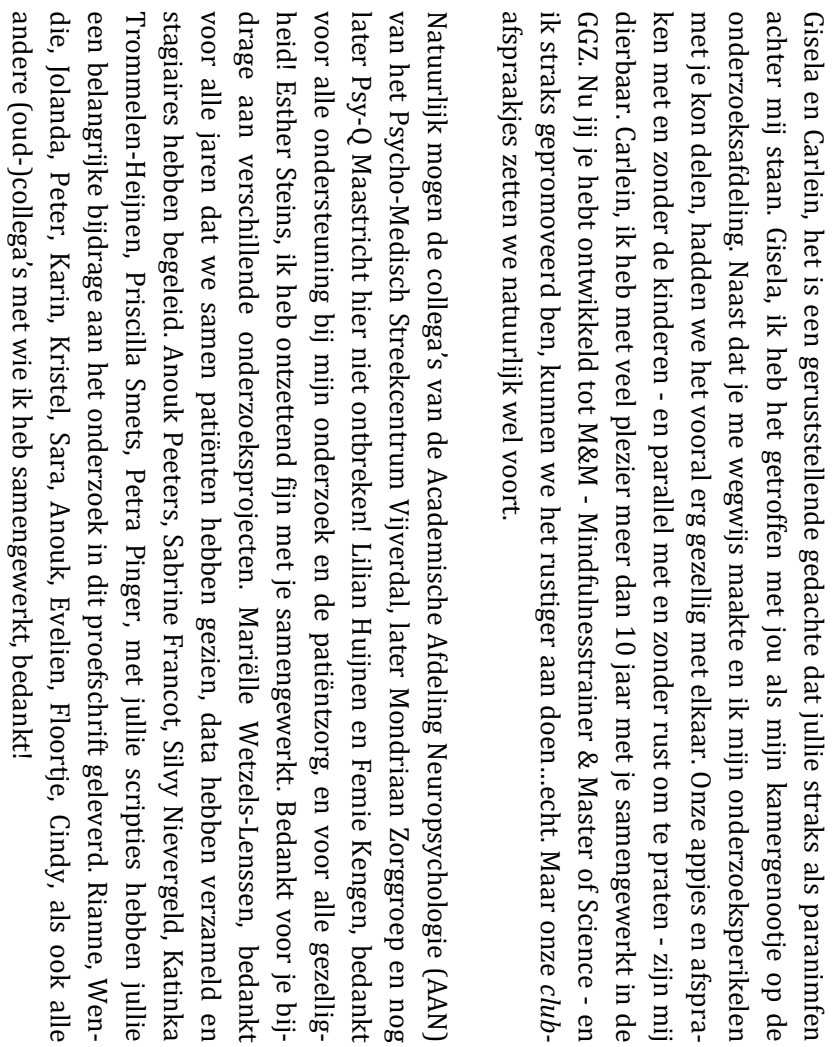




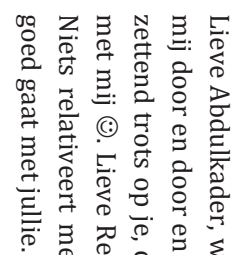

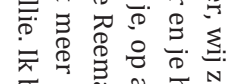

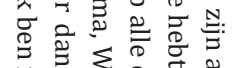

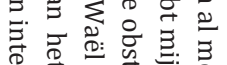

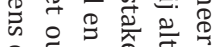

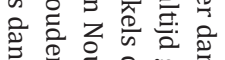

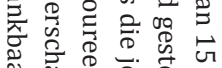
每

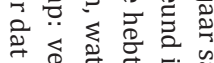

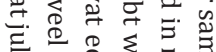

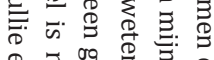

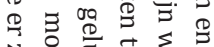
츨. 荡

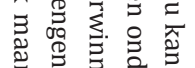
势 害

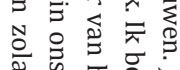

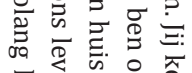

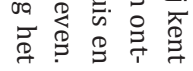

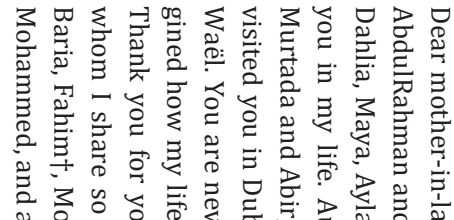

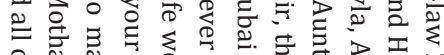

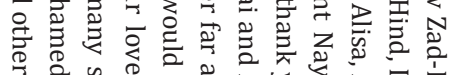

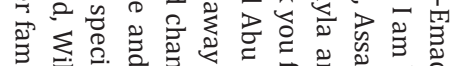

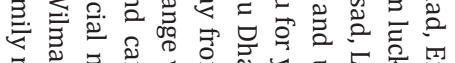

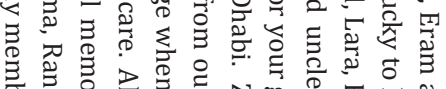

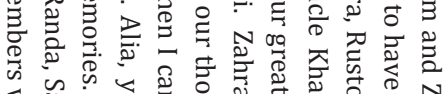

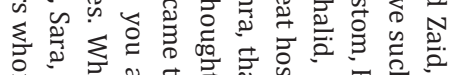

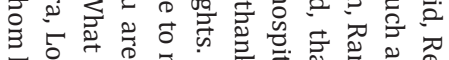

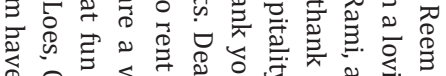

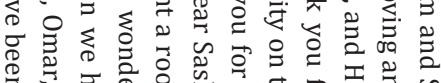

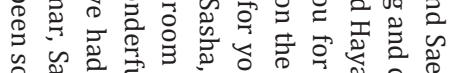

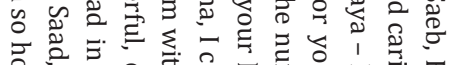

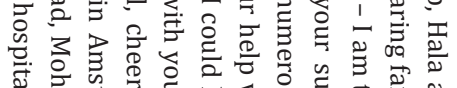

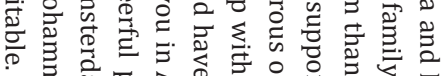

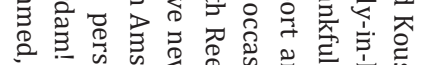

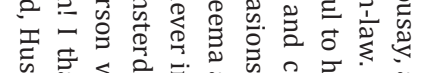

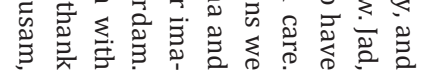

놀.

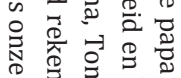

$\vec{P}$

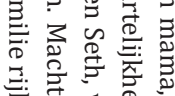

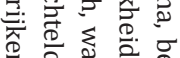

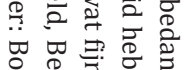

告.

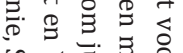

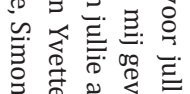

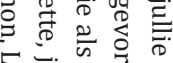

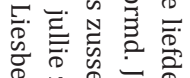

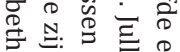

马

年.

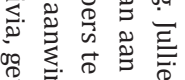

造

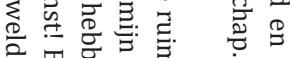

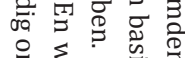

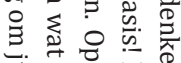

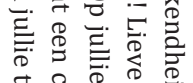

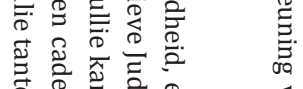

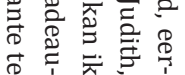

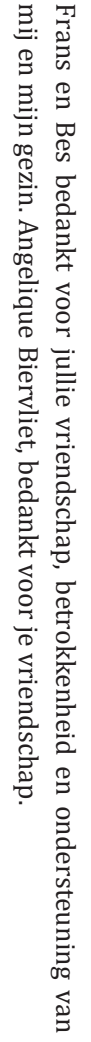

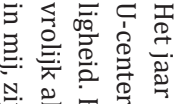

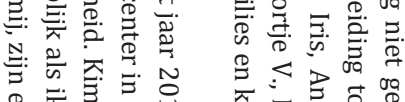

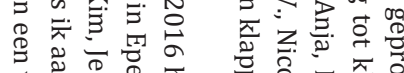

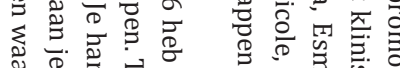

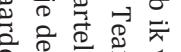

के 일

은 중 $\mathrm{N}$

\%o

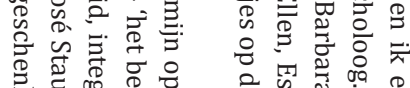

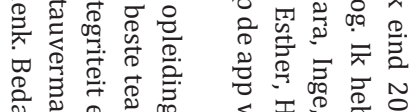

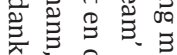

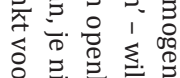

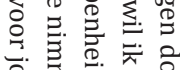

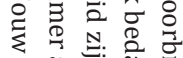

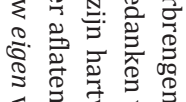

畓

政.

을

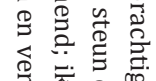

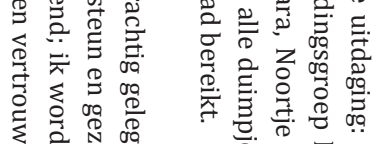
要
을

可 츙. 设

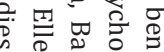

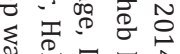

产

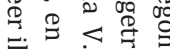

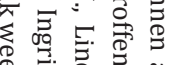

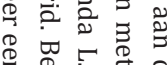

융

를 흠

엥

을 증항. 흥

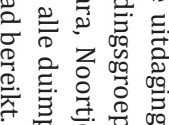




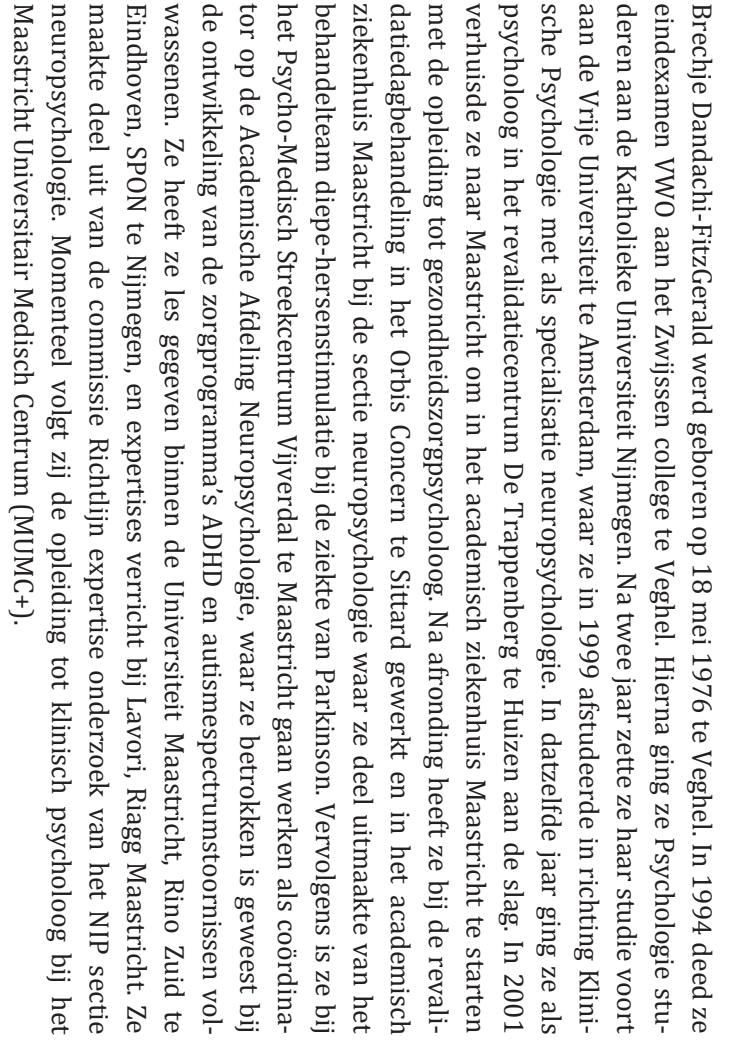




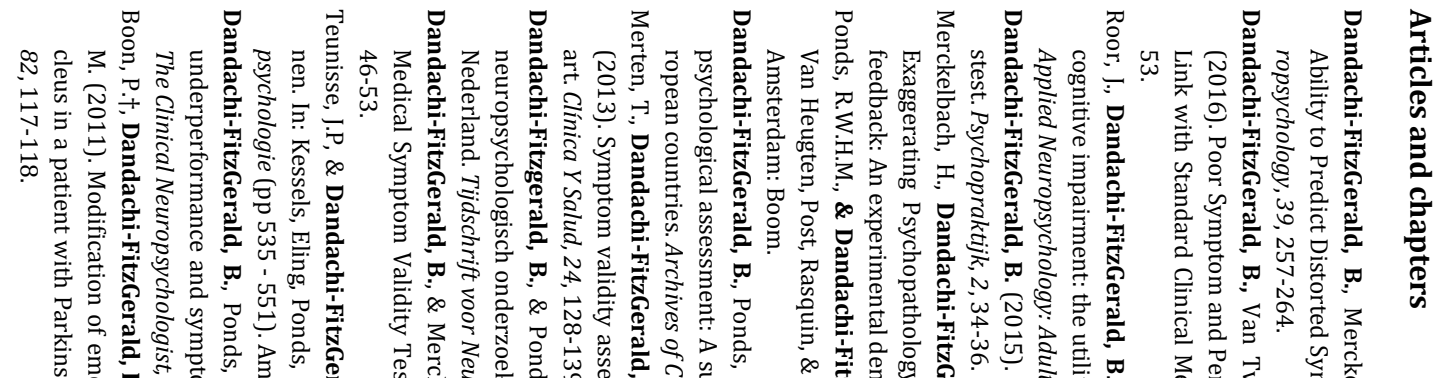
WWin Momp IIs:

In

Yis?

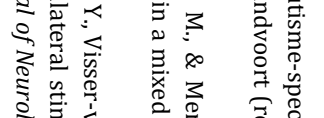

章

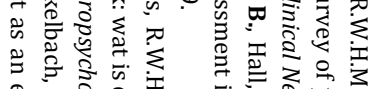

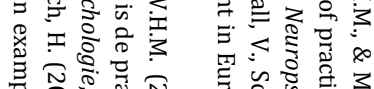

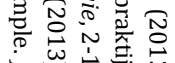

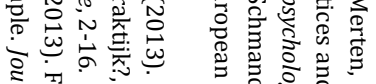

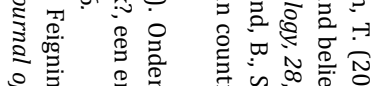

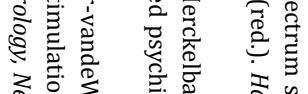

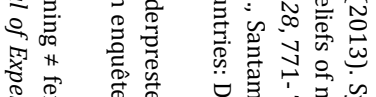

इํ.

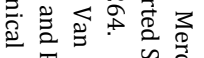

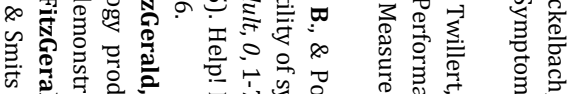

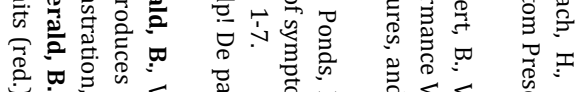

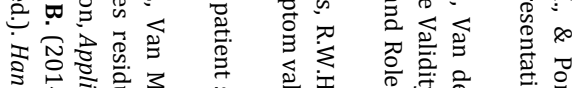

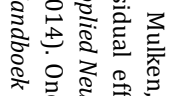

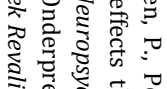

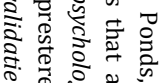

蛋 喝.

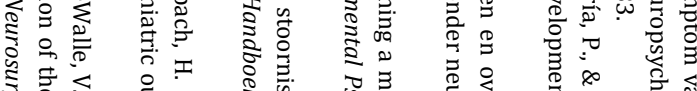

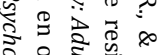

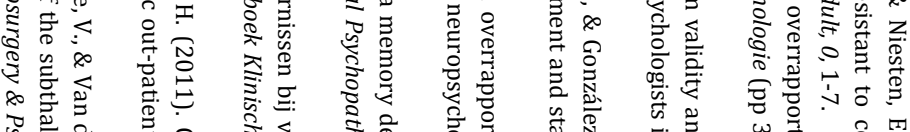

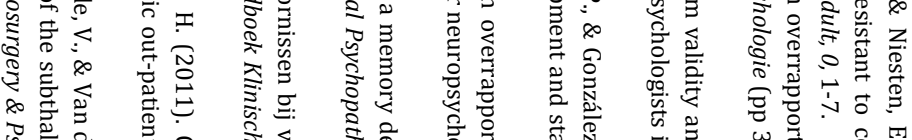

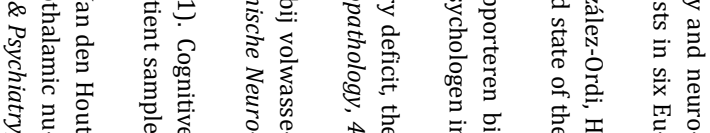

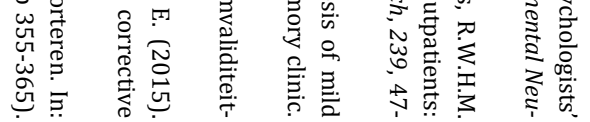

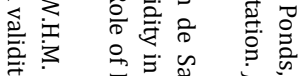

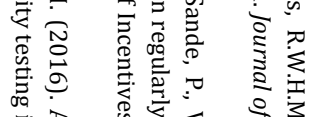

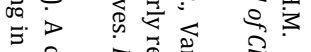

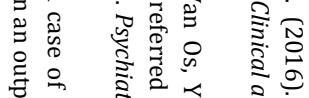

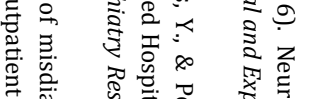

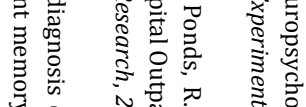

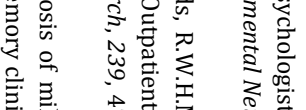

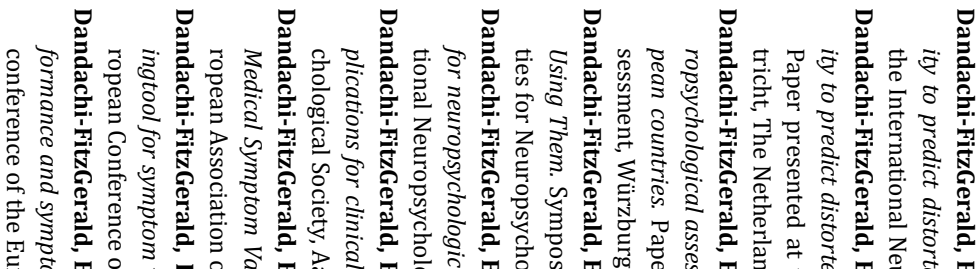

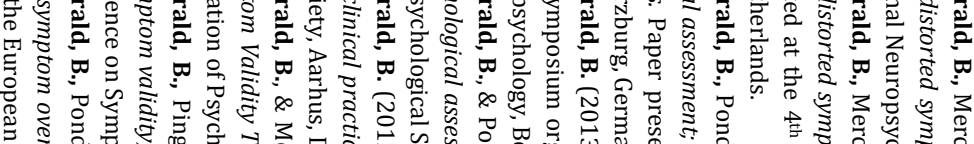

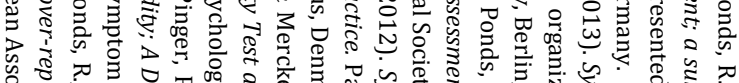

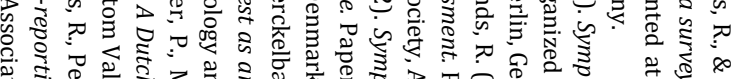

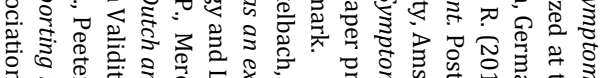

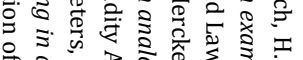

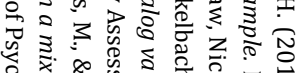

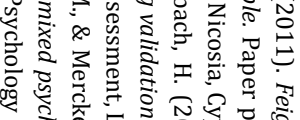

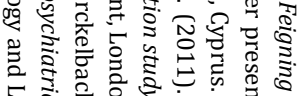

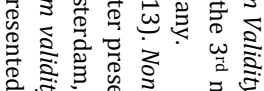

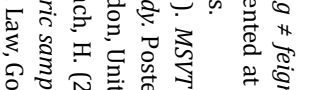

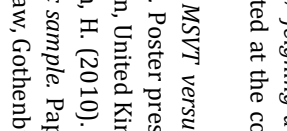

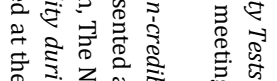

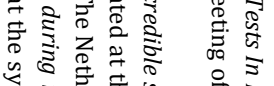

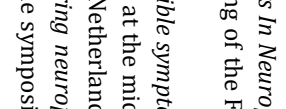

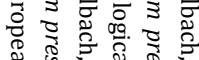

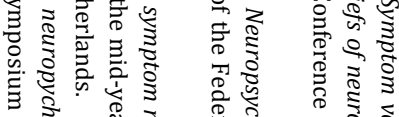

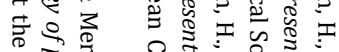

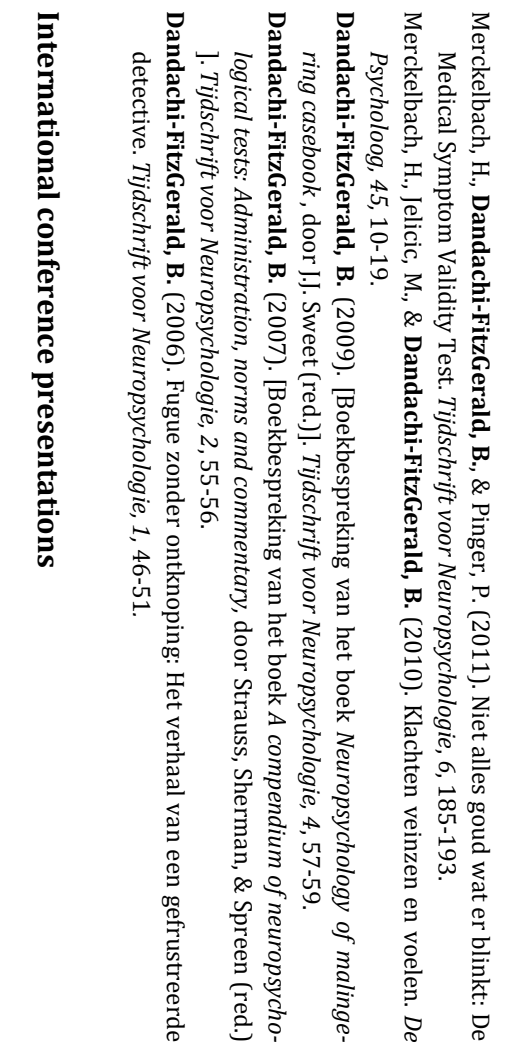



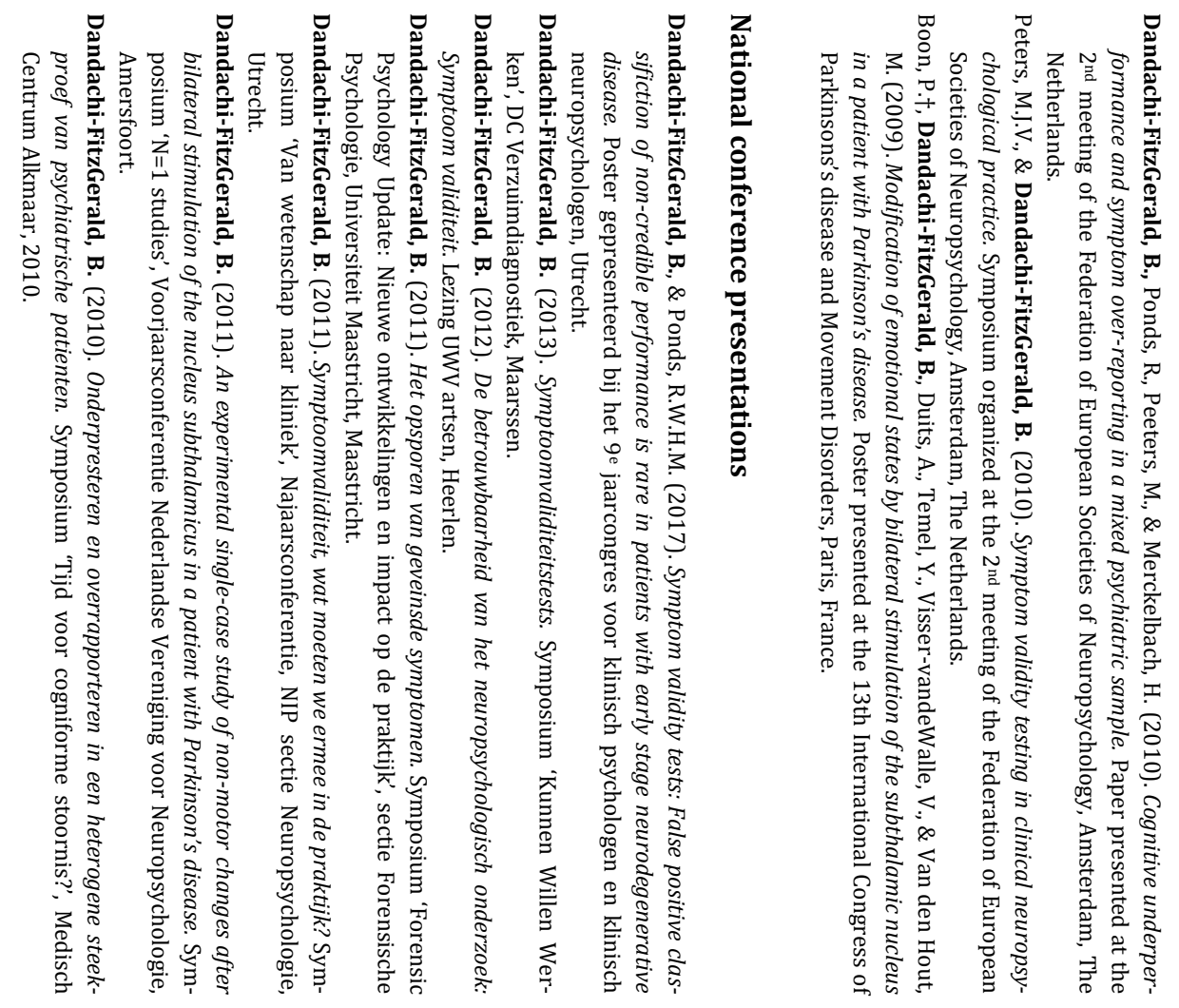
